INSTITUTO DE PESQUISAS ENERGÉTICAS E NUCLEARES Autarquia Associada à Universidade de São Paulo

\title{
AVALIAÇÃO DO IMPACTO DE AGROTÓXICOS EM ÁREAS DE PROTEÇÃO AMBIENTAL, PERTENCENTES À BACIA HIDROGRÁFICA DO RIO RIBEIRA DE IGUAPE, SÃO PAULO. UMA CONTRIBUIÇÃO À ANÁLISE CRÍTICA DA LEGISLAÇÃO SOBRE O PADRÃO DE POTABILIDADE.
}

MARIA NOGUEIRA MARQUES

Tese apresentada como parte dos requisitos para a obtenção do Grau de Doutor em Ciências na Área de Tecnologia Nuclear - Materiais

ORIENTADORA:

Dra. Maria Ap. Faustino Pires

SÃO PAULO

2005 
A Deus, à minha Mãe e à minha Família, pelo amor, apoio $e$ estímulo incondicionais, a mim oferecidos. 


\section{AGRADECIMENTOS}

À Dra. Maria Aparecida Faustino Pires pela orientação, incentivo e amizade.

A CAPES - Coordenação de Aperfeiçoamento de Pessoal de Nível Superior pelo apoio financeiro.

À FAPESP - Fundação de Amparo a Pesquisa do Estado de São Paulo pelo apoio financeiro de infraestrutura.

Ao Eng. Ademar B. Lugão, Gerente do Centro de Química e Meio Ambiente (CQMA) e ao Instituto de Pesquisas Energéticas e Nucleares, pela oportunidade de realizar o trabalho.

À Sabesp - Companhia de Saneamento Básico do Estado de São Paulo pela parceria e colaboração no projeto de pesquisa, em especial ao Mauro Ignácio, ao Orlando Antunes Cintra Filho e ao Osvaldo Beltrame Filho pelas contribuições e discussões técnicas. E ao Célio Sousa, ao Guilherme Francisco Gomes da Silva, ao Diomédes Rufino de Almeida, ao Eduardo Okawa, ao Ivon João Villanova, ao Itamar Teixeira de Oliveira, ao Júlio Cesar de Morais, ao Sebastião Kierme dos Santos por colaborarem nas coletas das amostras e realizarem as análises físico-químicas.

À Applied Biosystems do Brasil Ltda pela parceria e colaboração, em especial ao Alexandre Wang, ao Antonio Brugnollo, ao Fábio V. Nano pelo auxílio e discussões técnicas e ao Daniel Temponi Lebre pelo auxílio e discussões técnicas e amizade.

À Vânia Casari Ramos pelo auxílio na realização das análises por SPE LC - UV/vis.

Aos amigos, Ajibola Issau Abadiru, Angélica Mégda da Silva, Augusta Viana, Carla Capoleti, Cleide Moreira da Silva, Cristina Siste, Elias Santana da Silveira, Elaine Martins, Emy Komatsu, Elizabeth Sonoda K. Dantas, Hélio Akira Furusawa, Hélio Alves Martins Júnior, Lídia Katsuóka, Luiz Eduardo Pires, Marcos José de Lima Lemes, Marta Yoshiko Maekawa, Marycel Barbosa Cotrim, Patrícia Castilho Mamono, Sandra Maria Cunha, Sérgio Luis Graciano Petroni e Edson Tocaia dos Reis pelo apoio, amizade e discussões técnicas.

A todos os colegas do CQMA pela colaboração na realização do trabalho. 
"A água de boa qualidade é como a saúde ou a liberdade. Só tem valor quando acaba". Guimarães Rosa 


\title{
Avaliação do Impacto de Agrotóxicos em Áreas de Proteção \\ Ambiental, Pertencentes à Bacia Hidrográfica do Rio Ribeira de \\ Iguape, SÃo Paulo. Uma Contribuição À AnÁlise Crítica da \\ Legislação Sobre PAdRÃo de Potabilidade.
}

\section{MARIa NogueIRa MARQUeS}

\begin{abstract}
RESUMO
No presente trabalho estudou-se a qualidade de recursos hídricos na Bacia Hidrográfica do Rio Ribeira de Iguape, localizada na região sudeste do estado de São Paulo. Esta é a única bacia no estado de São Paulo onde a relação disponibilidade de água versus demanda é extremamente positiva. $\mathrm{Na}$ região está localizada a maior concentração de Mata Atlântica do país. Atualmente, a agricultura é a principal atividade econômica, destacando-se as culturas do chá e da banana. Avaliou-se o impacto da atividade agrícola na qualidade da água por meio da caracterização da água em áreas de captação superficial e da água destinada ao abastecimento público. Realizou-se uma análise de risco do potencial de contaminação por agrotóxicos em águas superficiais e subterrâneas, analisando as características físico-químicas dos princípios ativos, dos produtos utilizados na região, relacionando-as com os aspectos básicos de meteorologia, hidrologia e características do solo. Realizaram-se 6 campanhas, sendo 5 campanhas no período de março de 2002 a fevereiro de 2003 e uma em janeiro de 2004, em 10 municípios situados ao longo do Rio Ribeira de Iguape e seus principais afluentes. Avaliaram-se os resíduos dos carbamatos (aldicarbe, carbofurano e carbaril), das triazinas (simazina e atrazina) e da nitroanilina (trifluralina) utilizando-se o método por extração em fase sólida e análise por cromatografia líquida de alta eficiência acoplada ao detector UV/visível (SPE-LC-UV/vis). Verificou-se que a qualidade da água está relacionada com os períodos de chuva e seca. No início do período chuvoso, observou-se um número maior de amostras positivas com os resíduos de
\end{abstract}


agrotóxicos bem como maior variabilidade nos parâmetros físico-químicos, das amostras de água superficial, devido ao alto índice pluviométrico da região que aumenta a lixiviação do solo. Do total de 152 amostras analisadas somente $24 \%$ apresentaram resíduos agrotóxicos. Desenvolveu-se uma metodologia para determinação de carbamatos, atrazinas e triazinas por extração em fase sólida e análise por cromatografia líquida de alta eficiência acoplada ao detector espectrometria de massas Tandem (SPE-LC-MS/MS). O método mostrou-se eficiente na determinação destes compostos,apresentando ótima sensibilidade e seletividade. Aplicou-se o método nas amostras coletadas em janeiro de 2004 e devido a sua sensibilidade, o carbofurano foi identificado nas 20 amostras analisadas, sendo que em três das amostras de água tratada apresentou o produto de degradação, 3-OH-carbofurano. Verificou-se que a Bacia já apresenta indícios de uso de agrotóxico na agricultura, embora, as concentrações observadas não comprometam a qualidade da água para o abastecimento humano. Realizou-se uma avaliação crítica da legislação vigente pertinente (Portaria nº 518/MS/04) e sua comparação com normas e legislações, tanto nacionais quanto internacionais. Discutiu-se a sua aplicação a partir de critérios tais como prazo legal de cumprimento, facilidade e dificuldades técnicas (análises físico-químicas, ensaios acreditados e logísticas) e custos. 


\title{
Assessment of the IMPACt OF Pesticides in ENVIRONMENTAL Preservation Areas from Ribeira de Iguape River, São Paulo. Critical Contribution to the Guidelines for Drinking-Water STANDARDS.
}

\section{Maria Nogueira Marques}

\begin{abstract}
This research was focused on the assessment of the water quality of Ribeira de Iguape River Basin, located in the Southeastern region of São Paulo State, where the ratio of water availability against demand is high. Reminiscent of Atlantic Forest represents high occupation of this area in Brazil. Agriculture is the main economic activity in the region, with tea and banana as the main crops. The impact of agricultural activities on the environment has been characterized in both the surface water areas of catchments and drinking water. For superficial and underground waters, risk analysis of the contamination by pesticides was carried out, correlating the physicochemical properties of the active compounds used in the region with some basic aspects of meteorology, hydrology and soil characteristics. Water samplings were carried out during the period March/2002 February/2003, and during January/2004 in 10 different catchments points along River Ribeira de Iguape and its main tributaries. Solid-phase extraction followed by high performance liquid chromatography coupled with UV/Vis detection (SPE-LCUV/vis) was used as an analytical method to monitor various classes of pesticides such as carbamates (aldicarb, carbofuran and carbaryl), triazines (simazine and atrazine), and nitroanilines (trifluralin). The results revealed that the water quality is associated with the season of rains and dries. Due to the high precipitation index in the beginning of the rainy season, pesticide residues were found in most samples, and high variability in their physicochemical properties was observed. Form 152 samples analyzed, only $24 \%$ showed the presence of pesticide. The specificity and sensitivity in the pesticides analyses was enhanced by a
\end{abstract}


methodology employing solid-phase extraction followed by high performance liquid chromatography coupled with tandem mass spectrometry (SPE-LC-MS/MS). Specifically, this method was applied to all samples collected in January of 2004. Carbofuran and its metabolite 3-OH-carbofuran were detected in 20 and three of the samples, respectively. Although the observed low pesticide concentrations should not compromise the water quality for drinking, the present work demonstrates the impact of pesticides use in agriculture. In a complementary study, the current guidelines for drinking-water standards ( $n^{\circ}$ 518/MS/04) were critically evaluated and discussed by comparing national and international rules and regulations. Technical applicability of the legislation, the difficulty to comply with the imposed deadlines, and the costs of attending such requisites has been further discussed, as well. 


RESUMO

1 INTRODUÇÃ

2 OBJETIVOS

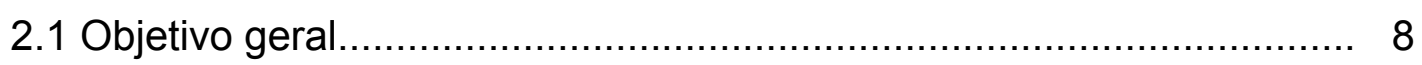

2.2 Objetivos específicos.................................................................. 8

2.3 Aspectos relevantes do trabalho................................................ 9

3. CONSIDERAÇÕES GERAIS SOBRE AGROTÓXICOS...................... 12

3.1 Demanda de água para o uso agrícola: uma avaliação do uso de

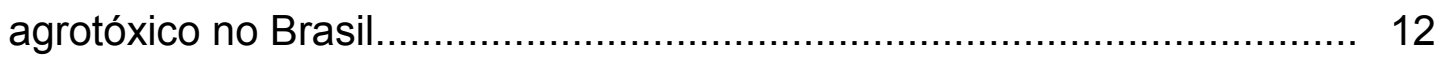

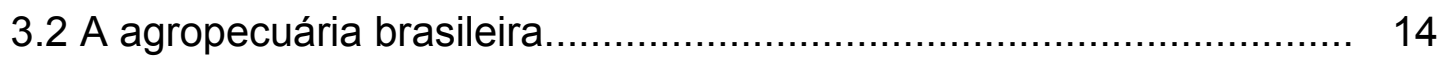

3.3 Agrotóxicos e qualidade de água................................................. 23

3.4 Agrotóxicos e sua aplicação na agricultura....................................... 29

3.5 Principais características dos agrotóxicos avaliados.......................... 34

3.6 Métodos para determinação de agrotóxicos....................................... 35

4 ÁREA DE ESTUDO

4.1 Características gerais da bacia................................................. 38 
4.2 Caracterização geomorfológica.

4.3 Recursos hídricos e o sistema de saneamento básico.

5.1 Análise crítica da legislação que estabelece o controle de qualidade das águas destinadas ao consumo humano

5.2 Reconhecimento da área de estudo.

5.2.1 Análise das condições climáticas

5.3 Análise do risco potencial de contaminação por agrotóxicos

5.3.1 Avaliação do potencial de lixiviação e percolação dos agrotóxicos

5.4 Otimização de metodologia para a análise multi-resíduos utilizando Cromatografia líquida de alta eficiência (LC) com detecção ultravioleta/visível (UV/vis) e espectrometria de massas em Tandem (MS/MS)

5. 4.1 Equipamento e materiais.

5.4.2 Reagentes e soluções.

5.4.3 Determinação de carbamatos, triazinas e nitroanilinas utilizando LC - UV/Visível.

5.4.4 Determinação de carbamatos, triazinas e nitroanilinas utilizando o LC - MS/MS.

5.5 Caracterização das Variáveis Físicas e Químicas. 66

5.5.1 Locais de amostragem e periodicidade de coleta. 66

5.5.2 Coleta, preservação e análise das amostras de água. 69 
6.1 Avaliação da área de estudo.

6.1.1 Uso e ocupação do solo

6.1.2 Agricultura e cobertura vegetal.

6.1.3 Uso de agrotóxico na região.

6.1.4 Reconhecimento da área

6.1.5 Avaliação dos parâmetros físico-químicos da qualidade da água superficial.

6.1.6 Avaliação da temperatura e precipitação. 88

6.2 Avaliação do potencial de lixiviação e percolação dos agrotóxicos como análise de risco.

6.2.1 Análise de risco.

6.2.1.1 Risco de contaminação de águas subterrâneas.

6.2.1.2 Risco de contaminação de águas superficiais

6.3 Otimização da metodologia para a análise multi-resíduos de carbamatos, triazinas e nitroanilinas utilizando LC - UV/Visível.

6.3.1 Limite de deteç̧ão (LD) e limite de quantificação (LQ). 103

6.3.2 Estudo de recuperação.

6.4 Desenvolvimento e otimização da metodologia para determinação de carbamatos, triazinas e nitroanilinas utilizando LC - MS/MS.

6.4.1 Estudo de linearidade

6.4.2 Estudo de recuperação. 
6.5 Variação dos parâmetros físico-químicos da água superficial e tratada

6.5.1 Análise dos parâmetros físico-químicos das amostras de água superficial e tratada.

6.6 Análise dos resíduos de agrotóxicos em amostras de água superficial e tratada.

6.7 Análise crítica da legislação que estabelece o controle de qualidade das águas destinadas ao consumo humano.

6.7.1 Comparação dos atuais parâmetros de potabilidade nacional com outras legislações.

6.7.2 Situação atual das Empresas Estatais de Saneamento Básico no cumprimento da Portaria atual de potabilidade.

7 CONCLUSÕES.

APÊNDICE A Tabela de comparação dos parâmetros de qualidade de água de diferentes legislações

APÊNDICE B Características, aplicação e classificação dos agrotóxicos quanto à toxidade.

APÊNDICE C Registro fotográfico para mostrar algumas atividades antrópicas da região

APÊNDICE D Resultado das análises das amostras de água da Bacia Hidrográfica do Rio Ribeira de Iguape.

APÊNDICE E Relação dos doze novos agrotóxicos inclusos no controle de padrão de potabilidade. 


\section{LISTA DE TABELAS}

TABELA 1 - Disponibilidade e Demanda de Água das Regiões Hidrográficas Brasileiras (ANA, 2003)................................................. 15

TABELA 2 - Relação dos dez agrotóxicos listados com maior volume de consumo no País, dados de 2000 (IBAMA, 2000; PNGSQ. 2003)............ 18

TABELA 3 - Intoxicação humana por agentes tóxicos (PNGSQ, 2003).. 24

TABELA 4 - Classificação toxicológica dos agrotóxicos (Larini, 1999)...... 33

Tabela 5 - Correspondência entre áreas protegidas por lei da UGRHI 11 e as categorias classificadas pela União Internacional para a Conservação da Natureza UICN (CETEC, 2000)....................................

TABELA 6 - Estimativa da demanda para irrigação nas sub-bacias (CETEC, 2002).

Tabela 7 - Evolução no atendimento do Sistema de Esgoto do Vale do Ribeira (dados fornecidos pela SABESP - Registro, 2002)..

TABELA 8 - Critérios para avaliação do potencial de contaminação de águas superficiais conforme método de Goss.

TABELA 9 - Programação do gradiente de eluição utilizando como fase móvel água $(A)$ e acetonitrila $(B)$

TABELA 10 - Descrição e agrupamento dos locais de coleta nas diferentes áreas de captação de água superficial e respectivas ETA's.....

TABELA 11 - Principais Regionais Produtoras de Banana do estado de São Paulo (C.A.T.I. - LUPA, 2004)..................................................... 7

TABELA 12 - Principais agrotóxicos comercializados no Vale do Ribeira. 77 Tabela 13 - Caracterização da Área de Estudo: usos da água; ETAs , captações e observações relevantes quanto o uso e ocupação do solo Unidade do Vale do Ribeira - SABESP. 
TABELA 14 - Propriedades físico-químicas a $20-25^{\circ} \mathrm{C}$ dos princípios ativos dos agrotóxicos usados na região da Bacia do Rio Ribeira e os avaliados neste trabalho

TABELA 15 Resultados da avaliação de risco de contaminação de águas subterrâneas com base nos critérios de "screening" estabelecido pela EPA e no índice de vulnerabilidade da água subterrânea (GUS).

TABELA 16 - Classificação dos princípios ativos usados na região e dos demais compostos avaliados neste trabalho, de acordo com o seu potencial de contaminação de águas superficiais.

TABELA 17 - Programação do gradiente de eluição utilizando como fase móvel água $(A)$ e acetonitrila $(B)$.

TABELA 18 - Parâmetros utilizados para os cálculos do LD e LQ.

TABELA 19 - Estudo de recuperação dos compostos avaliados em amostras de água ultrapura, água superficial e água tratada.

TABELA 20 - Valores otimizados para os parâmetros da interface e o gás de colisão.

TABELA 21 - Parâmetros de operação para as medidas de MS/MS.

TABELA 22 - Condições cromatográficas e gradiente das soluções eluentes

TABELA 23 - Parâmetros obtidos no estudo de linearidade com padrões diluído em água ultrapura

TABELA 24 Parâmetros obtidos no estudo de linearidade com padrões diluídos em solução $50 \%$ ACN e água ultrapura

TABELA 25 - Resultados do ensaio de recuperação dos agrotóxicos utilizando injeção direta no sistema LC - MS/MS.

TABELA 26 - Recuperação do método SPE - LC - MS/MS em amostras de água ultrapura e água superficial. 
TABELA 27 - Limites de detecção e quantificação obtidos para o método SPE - LC - MS/MS

TABELA 28 - Relação do limite de detecção de alguns métodos multiresíduos adotado pela literatura consultada.

TABELA 29 - Ocorrência de resíduos de agrotóxicos em amostras de água superficial da Bacia Hidrográfica do rio Ribeira de Iguape, durante o período de março/2002 a fevereiro/2003 e em janeiro/2004.

TABELA 30 - Ocorrência de resíduos de agrotóxicos em amostras de água tratada da Bacia Hidrográfica do rio Ribeira de Iguape, durante o período de março/2002 a fevereiro/2003 e em janeiro/2004

TABELA 31 - Resultado da determinação de resíduos de agrotóxicos em amostras de água superficial (BR) e tratada ( $F N)$, pertencentes à Região do Vale do Ribeira analisadas por SPE - LC - MS/MS, janeiro de 2004 .......

TABELA 32 - Alterações da Portaria de potabilidade vigente. Comentários sobre os pontos mais significativos realizados pelos técnicos em saneamento.

TABELA 33 - Pontos relevantes estabelecidos entre os parâmetros químicos de potabilidade e as legislações nacionais referentes à qualidade da água.

TABELA 34 - Pontos relevantes estabelecidos entre os parâmetros químicos da atual Portaria n $510 / \mathrm{MS} / 04$ e as legislações internacionais referentes à qualidade da água.

TABELA 35 - Empresas Estatais de Saneamento Básico com estrutura laboratorial própria.

TABELA 36 - Análises e a freqüência das coletas. 
TABELA 37 - Número de Empresas Estatais de Saneamento Básico com estrutura laboratorial própria que executam os parâmetros da legislação de potabilidade vigente.

TABELA A - Parâmetros de qualidade de água de legislações Federais, do Estado de São Paulo e Internacionais.

TABELA D - Resultado das análises realizadas por SPE - LC UV/visível.

TABELA E - Informações relevantes dos 12 agrotóxico inclusos nos parâmetros de potabilidade. 


\section{LISTA DE FIGURAS}

FIGURA 1 - Consumo de agrotóxico por Estado, no Brasil (ano base 2000 - SINDAG, 2002; adaptado por Marques, M.N.).

FIGURA 2 - Perfil da venda de agrotóxicos no Brasil no período de 1999 a 2001 (SIDAG, 2001).

Figura 3 - Agrotóxicos comercializados por classe toxicológica no Brasil no período de 1992 a 2002 (SINDAG, 2004)

FIGURA 4 - Média do consumo de agrotóxico por cultura no Brasil no período de 1997 - 2000 (SINDAG, 2002; adaptado por Marques, M.N.)... 21

FIGURA 5 - Uso de Agrotóxicos $\left(\mathrm{kgha}^{-1}\right)$ e área plantada (ha) (Fontes: SINDAG, 2002; IBGE, 2002).

FIGURA 6 - Área de Cultura por Hectare, no Estado de São Paulo (IBGE, 1997 - adaptado por Marques, M.N.).

FIGURA 7 - Movimento dos agrotóxicos no meio ambiente por meio de caminhos abióticos e bióticos (Hayes \& Laws, 1997).

FIGURA 8 - Localização da Bacia Hidrográfica do Ribeira de Iguape, no Estado de São Paulo.

FIGURA 9 - Distribuição da área ocupada por floresta tropical natural no estado de São Paulo (CATI - LUPA, 2004) e distribuição por Unidade de Conservação, na Bacia Hidrográfica do Ribeira de Iguape, SP.

FIGURA 10 - Mapa Geomorfológico da Bacia do Rio Ribeira de Iguape Escala 1:500.000, Adaptado de IPT (1994).

FIGURA 11 - Comparação disponibilidade $\left(Q_{7,10}\right) X$ demanda (D) para a Bacia Hidrográfica do Rio Ribeira de Iguape (CETEC, 2000).

FIGURA 12 - Representação esquemática de um processo utilizando espectrômetro de massas. 
FIGURA 13 - Mapa da Bacia Hidrográfica do Ribeira de Iguape com identificação das estações de coleta: captações superficiais e ETAs...

FIGURA 14 - Distribuição da Densidade de Mata Atlântica (INPE, 2004). 73

FIGURA 15 - Uso e ocupação do solo na Bacia Hidrográfica do Rio Ribeira de Iguape

FIGURA 16 - Principais produtores de banana no Brasil, no período de 1992 a 2001 (Ministério da Agricultura, 2004; adaptado por Marques, M.N.).

FIGURA 17 - Variação da alcalinidade da água superficial no período de Janeiro/96 a Abril/99, nas ETAs de Iguape, Eldorado, Registro, Sete Barras, Iporanga e Juquiá

FIGURA 18 - Variação da cor da água superficial no período de Jan/96 a Jan/99, nas ETAs de Iguape, Eldorado, Registro, Sete Barras, Iporanga e Juquiá

FIGURA 19 - Variação da turbidez da água superficial no período de Jan/96 a mar/99, nas ETAs de Iguape, Eldorado, Registro, Sete Barras, Iporanga e Juquiá

FIGURA 20 - Variação da pH da água superficial no período de Jan/97a Jul/00, nas ETAs de Iguape, Eldorado, Registro, Sete Barras, Iporanga e Juquiá.

FIGURA 21 - Diagramas climáticos das Estações Meteorológicas de Cananéia, Eldorado, Jacupiranga e Jacupiranga-CA, da UGRH Ribeira de Iguape e Litoral Sul no período de 2000 a 2003. (CIAGRO, 2003; adaptado por Marques, M.N.)

FIGURA 22 - Diagramas climáticos das Estações Meteorológicas de Miracatu, Pariquera-Açu, Sete Barras e Registro da UGRH Ribeira de Iguape e Litoral Sul no período de 2000 a 2003. (CIAGRO, 2003; adaptado por Marques, M.N.). 
FIGURA 23 - Diagrama climático da UGRH Ribeira de Iguape e Litoral Sul no no período de 2000 a 2003. (CIAGRO, 2003; adaptado por Marques, M.N.)

FIGURA 24 - Cromatograma de uma amostra padrão, concentração de cada composto: $0,20 \mathrm{mgL}-1$ (massa injetada $=4 \mathrm{mg}$ ).

FIGURA 25 - Cromatogramas de: uma amostra de água superficial (Rio Ribeira de Iguape, ponto de captação de Eldorado) e da amostra com adição de padrão, na concentração de $1,0 \mathrm{mgL}^{-1}$ de cada composto.

FIGURA 26 - Cromatogramas de uma amostra de água tratada, proveniente da ETA de Iguape, e da amostra com adição de padrão, na concentração de $1,0 \mathrm{mgL}^{-1}$ de cada composto.

FIGURA 27 - (a) espectro de massas dos carbamatos, (b) espectro de massas MS/MS do carbofurano e (c) espectro de identificação do precursor (carbofurano) do íon produto de $\mathrm{m} / \mathrm{z}=165$.

FIGURA 28 - Cromatograma dos compostos analisados nas concentrações de $2,0 \mathrm{ngmL}^{-1}$ para os carbamatos e triazinas e $200 \mathrm{ngmL}^{-}$ ${ }^{1}$ para trifluralina utilizando LC - MS/MS.

FIGURA 29 - Índice de pH de água superficial e tratada por município....

FIGURA 30 - Índice de cor de água superficial e tratada por município....

FIGURA 31 - Índice de turbidez de água superficial e tratada por município.

FIGURA 32 - Variação temporal e espacial dos valores das amostras de água superficial.

FIGURA 33 - Variação temporal e espacial dos valores das amostras de água Tratada. 
FIGURA 34 - Variação temporal e espacial dos valores da cor das amostras de água superficial.

FIGURA 35 - Variação temporal e espacial dos valores da turbidez das amostras de água superficial.

FIGURA 36 - Variação temporal e espacial dos valores da turbidez das amostras de água tratada.

FIGURA 37 - Representação esquemática dos pontos de coletas e do uso e ocupação do solo identificando as principais fontes de poluição da Bacia Hidrográfica do Rio Ribeira de Iguape.

FIGURA 38 - Gráficos da porcentagem de amostras que apresentaram resposta positiva na identificação e quantificação dos agrotóxicos analisados

FIGURA 39 - Gráfico comparativo de intensidade pluviométrica e o número de amostras positivas para resíduos dos agrotóxicos estudados.

FIGURA 40 - Densidade da distribuição sazonal dos agrotóxicos analisados para os pontos de captação de Registro, Cajati, Sete Barras, Barra do Turvo, Cananéia e Eldorado, no período de março de 2002 a fevereiro de 2003 e em janeiro de 2004, água superficial e água tratada.. 132

FIGURA 41 - Densidade da distribuição sazonal dos agrotóxicos analisados para os pontos de captação de Juquiá, Iguape, Juquitiba e Iporanga, no período de março 2002 a fevereiro de 2003 e em janeiro de 2004, água superficial e água tratada.

FIGURA 42 - Comparação quantitativa do número de amostras em populações entre 1 e 1.000 .000 de habitantes (Cintra Filho, O. A.,2001). 141 


\section{INTRODUÇÃO}

A água é a substância química mais abundante da matéria viva e desempenha funções importantes como: solvente de líquidos corpóreos; meio de transporte de moléculas; regulação térmica; ação lubrificante; atuação nas reações de hidrólise, etc. A taxa de água varia em função da idade do organismo. Um feto humano de três meses, por exemplo, contém, aproximadamente, 94\% de água, enquanto que um recém-nascido $70 \%$ e um homem adulto $65 \%$. Segundo a hipótese heterotrófica, mais aceita atualmente, as primeiras formas de vida surgiram no fundo dos mares e oceanos primitivos (Paulino, 1991).

As civilizações mais antigas desenvolveram-se às margens dos grandes rios como as colônias da Mesopotâmia que se estabeleceram ao longo do chamado "Crescente Fértil", entre os rios Tigre e Eufrates, durante o período de 10.000 a 5.000 a.C. Nesse período um extraordinário conhecimento foi adquirido para amenizar as necessidades de sobrevivência, com demonstrações de grande engenhosidade.

Desenvolveram-se técnicas agrícolas, drenagens dos pântanos do sul, irrigações das terras, construções de casas de tijolo de barro, etc (Rebouças, 1999). Algumas destas civilizações chegaram a desenvolver diversas obras relacionadas ao saneamento, tais como: as galerias de esgotos construídas em Nippur, na Índia, por volta de 3.750 a.C; o abastecimento de água e a drenagem encontrada no Vale do Indo em 3.200 a.C., onde, muitas ruas possuíam canais de esgotos, cobertos por tijolos com aberturas para inspeção, e as casas eram dotadas de banheiras e privadas, lançando o efluente diretamente nesses canais; o uso de tubos de cobre como os do palácio do faraó Cheóps; a clarificação da água de abastecimento pelos egípcios em 2.000 a.C., utilizando o sulfato de alumínio (Silva, 1998).

Nessa época, já existiam preocupações quanto ao uso da água e à transmissão de doenças a ela vinculadas. Documentos em sânscrito datados de 2.000 a.C. aconselhavam o acondicionamento da água em vasos de cobre, a sua exposição ao sol e filtragem através do carvão, ou ainda, pela imersão de barra 
de ferro aquecida, bem como o uso de areia e cascalho para filtração da água. Por volta de 1500 a.C., os egípcios utilizavam a decantação. Bem mais tarde, a partir de 450 a.C., poços artesianos eram escavados na busca por suprimento de água em regiões áridas (Tatton, 2004).

Quanto aos aspectos qualitativos da água, Platão (427-347 a.C.) já considerava a necessidade de disciplinar o seu uso e prescrevia alguma forma de penalização para aqueles que causassem prejuízos aos corpos d’água, pois, para ele, a água era a coisa mais necessária à manutenção das plantações (Silva, 1998).

A humanidade, até algumas décadas atrás, tinha a água como um bem infinito e que a capacidade de autodepuração dos corpos d'água também o era. Mas nas últimas décadas, o rápido desenvolvimento industrial, o aumento do número de habitantes e da produtividade agrícola trouxeram como conseqüência a preocupação com a qualidade e disponibilidade da água para consumo humano devido à rápida degradação dos corpos d’água.

Estes fatos mostraram a fragilidade da capacidade autodepurativa do ciclo aquático mediante a grande demanda exigida pelos sistemas sócioeconômicos da sociedade atual, mostrando-nos que os recursos hídricos são um bem finito e, portanto, exigem uma atenção especial na gestão de seu uso, além da necessidade eminente de se promover o saneamento dos esgotos urbanos e um controle rigoroso nos rejeitos industriais descartados nos corpos d’água.

O texto mais antigo a respeito do combate à poluição das águas é datado de 1829 (Pompeu, 1976) o qual previa a punição com multa ou prisão a quem atirasse nas águas drogas e produtos que provocassem nas águas 0 envenenamento ou destruição dos peixes. Essa lei visava mais a pesca predatória do que propriamente a poluição das águas.

No Brasil, o Código de Águas (BRASIL, 1934) vinculava o controle e incentivo das águas para uso industrial ao poder público, definia medidas para facilitar e garantir o aproveitamento da energia hidráulica e colocava o Ministério 
da Agricultura como executor deste decreto. Além de regras específicas para aproveitamento da energia hidráulica há a previsão de usos da água para navegação e para derivação, onde se define o regime de concessões e autorizações.

As epidemias que atingiram os países europeus, durante séculos, impulsionaram a busca por medidas técnicas sanitárias, possibilitando o desenvolvimento científico e sanitário. A preocupação com os problemas ambientais somente teve fórum no final da década de sessenta, com a primeira discussão internacional sobre a adoção de políticas envolvendo aspectos ambientais, realizada em Roma no ano de 1968 (Clube de Roma, 2004).

Devemos lembrar que as normas e os padrões de qualidade asseguram e protegem a saúde pública e o meio ambiente, disciplinando o uso. Devem atender a prioridades nacionais, fatores econômicos, segurança e saúde com base em conhecimento tecnológico (Pires, 2004).

Neste contexto, surgiu a necessidade da criação de órgãos ou agências responsáveis pelo controle e estabelecimento de critérios e concentrações máximas permissíveis dos poluentes, como por exemplo em águas naturais e para o abastecimento público.

A Agência de Proteção Ambiental Americana - EPA (Environmental Protection Agency, 2000) e a Agência Ambiental Européia - EEA (European Environmental Agency) (Barceló, 1993) são agências internacionais que sugerem estes valores máximos permissíveis nos Estados Unidos e na Europa, respectivamente. A Organização Mundial da Saúde (OMS) sugere estes valores no âmbito mundial por meio do guia para qualidade de água potável.

No Brasil, o Conselho Nacional de Meio Ambiente (CONAMA) é o órgão responsável pela elaboração de normas e padrões compatíveis com o meio ambiente ecologicamente equilibrado e essencial à sadia qualidade de vida. 
A Resolução CONAMA no 20/86 (atualmente em fase de revisão) e a Lei Estadual de São Paulo nº 997/79, regulamentada pelo Decreto nำ 8.468/76 tratam os recursos hídricos por classes, diferenciando-as pelos padrões numéricos de emissão dos poluentes que podem ser lançados nos corpos d’água.

No Brasil, o controle de qualidade da água de abastecimento público é efetuado através de dois instrumentos. O primeiro deles é executado pelo próprio produtor, o qual é denominado "controle operacional", e visa à adaptação dos processos produtivos para o atendimento de qualidade pré-estabelecido. $O$ segundo instrumento designado "controle legal" ou vigilância sanitária, deveria ser realizado por entidades distintas, autônomas e independentes, sendo atribuição dos Ministérios de Saúde ou, por delegação das Secretarias Estaduais de Saúde (Pires, 2004).

A Portaria nํ518/MS/04 estabelece os padrões atuais de potabilidade de água para o abastecimento público no território nacional. Esta Portaria promoveu uma prorrogação de 12 meses para sua implantação a partir de sua publicação (30 de Março de 2004), sendo uma cópia praticamente fiel do texto da Portaria no 1469/MS/00. As alterações se encontram no capítulo III, seção I Art. 5은 que delega a competência para editar normas regulamentadoras desta Portaria ao presidente da Fundação Nacional de Saúde (FUNASA) e passa a delegar ao

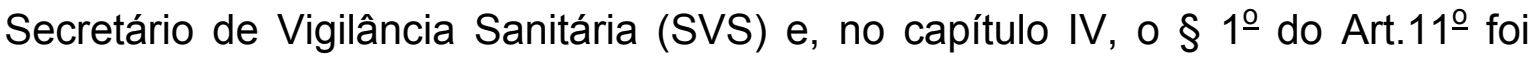
dividido em dois parágrafos.

A Portaria no 1469/MS/00, foi mais abrangente que a anterior, a Portaria $\mathrm{n}^{\circ}$ 36/MS/90, abordando temas como controle e gerenciamento de mananciais, controle de cianobactérias e a inserção de novas substâncias nos padrões de potabilidade como antimônio, acrilamida e alguns agrotóxicos.

No estado de São Paulo, a Resolução SS no 178/96 da Vigilância Sanitária do Estado orienta as empresas responsáveis pelo abastecimento público de água potável no sentido de efetuarem os seus respectivos cadastramentos junto à Vigilância Sanitária do Estado. Apresentar seus próprios planos mensais e semestrais de amostragem e efetuar, elas próprias, o controle 
da qualidade da água que produzem. Institucionalizando uma prática já bem difundida no país, de se outorgar ao produtor de água potável, a competência legal, para que ele próprio exerça a vigilância sanitária da água que produz.

A Portaria n- 518/MS/04 concorda com esta prática, delegando aos responsáveis pela Operação de Sistema o controle da qualidade da água produzida e distribuída (seção IV, art. $8^{\circ}$ e $9^{\circ}$ ) e a elaboração dos planos de amostragem (capítulo $\mathrm{V}$, art $18^{\circ}$ e $19^{\circ}$ ).

O presente projeto, em apoio ao desenvolvimento de políticas públicas relacionadas a controle da qualidade de água, tem como proposta realizar uma análise crítica da Norma Nacional sobre a qualidade de água para abastecimento Público, com ênfase aos agrotóxicos, trazendo subsídios que contribuam para seu atendimento e revisão, de modo que sejam concordantes com a realidade dos estados e do país.

Pretendeu-se com o presente trabalho aprofundar os conhecimentos sobre as complexas e estreitas relações dos agrotóxicos no controle dos parâmetros de qualidade de água para o abastecimento público, (água superficial e tratada), o uso e ocupação do solo e a bacia hidrográfica.

Como área de estudo escolheu-se a Bacia Hidrográfica do Rio Ribeira de Iguape, por ser uma região economicamente agrícola, com extensas Áreas de Preservação Ambiental - APA's. Além de ser considerada uma das mais importantes reserva de recursos hídricos do estado de São Paulo é a principal e maior "porção" nacional de Mata Atlântica ainda preservada. A Bacia está localizada na região sul do Estado, a 200km da Grande São Paulo, no principal eixo do Merco Sul.

Dois aspectos fundamentais para o entendimento do presente estudo foram discutidos: o estreito entrelaçamento do uso e ocupação do solo e a comercialização de agrotóxico de forma regionalizada, como estratégia para avaliação dos mananciais de captação superficial e sistemas produtores e as características físicas da região. 
Embora, considerada uma área ambientalmente preservada a região tem a bananicultura como principal fonte econômica. Portanto, os efeitos negativos do uso de agrotóxicos foram assuntos tratados neste estudo.

Ao se estabelecerem valores referência para qualidade da água potável, vários critérios são definidos e aplicados para selecionar os diversos contaminantes químicos, físicos, microbiológicos e radiológicos incluindo a descrição dos métodos utilizados para a obtenção desses valores. Mesmo que o número de contaminantes químicos, para os quais se reconheçam os valores referência, seja elevado é pouco provável que todos eles estejam presentes em todos os sistemas de abastecimento de água ou que sejam inclusos nas normas em todos os países (OMS, 1995).

Por esta razão, as substâncias objeto das normas nacionais devem ser cuidadosamente selecionadas. Uma série de fatores como: as características geológicas e o tipo de atividade humana desenvolvida na região também devem ser observadas. Por exemplo, em uma região em que não se utiliza um tipo de agrotóxico será pouco provável a presença deste na água de abastecimento.

Dessa forma, foram avaliados neste trabalho os compostos: aldicarbe, carbofurano e carbaril do grupo dos carbamatos; a simazina e atrazina do grupo das triazinas; e a trifluralina do grupo das nitroanilinas.

Vários fatores foram observados para a escolha desses agrotóxicos: 1) sua utilização, tanto em escala mundial, nacional e regional; 2) freqüência nos estudos de monitoramento internacionais, tanto em água bruta como tratada; 3) ausência de informação e de dados de monitoramento em escala nacional e regional e 4) persistência e características físico-químicas. (Barceló, 1993; Biziuk, 1996; Dean, 1996; Marques, 2003, Katsuóka, 2001; Stackelberg, 2001; Quintana, 2000; Hernández, 2001; Azevedo, 2000; René Van Der Hoff, 1999).

Vale salientar que o carbofurano e o carbaril estão entre os agrotóxicos mais empregados na área de estudo e que, a simazina, a atrazina e a trifluralina estão entre os agrotóxicos inclusos como parâmetro de controle de potabilidade. 
A Norma que estabelece o Padrão de Potabilidade emprega o termo "agrotóxico" para esta classe de compostos, embora, a literatura adote diferentes termos. Larini (1999) define e recomenda usar o termo praguicida para a classe de produtos destinados ao combate de pragas:

"Os praguicidas são compostos químicos especialmente empregados pelo homem para destruir, repelir, ou mitigar pragas (insetos, ácaros, nematóideos, roedores e outras formas de vida animal, fungos, plantas daninhas terrestres e aquáticas). Têm também função preventiva contra as pragas. Além disso, funcionam como desfolhantes e dessecantes, ou ainda como reguladores do crescimento de vegetais".

A Legislação Federal adota e define o termo agrotóxico na Lei no 7.802 , de 11 de julho de 1989, como:

a) os produtos e os agentes de processos físicos, químicos ou biológicos, destinados ao uso nos setores de produção, no armazenamento e beneficiamento de produtos agrícolas, nas pastagens, na proteção de florestas, nativas ou implantadas, e de outros ecossistemas e também de ambientes urbanos, hídricos e industriais, cuja finalidade seja alterar a composição da flora ou fauna, a fim de preservá-las da ação danosa de seres vivos considerados nocivos;

b) substâncias e produtos empregados como desfolhantes, dessecantes, estimuladores e inibidores de crescimento.

Este projeto contempla as ferramentas analíticas do programa de pesquisa em Políticas Públicas, contribuindo para a melhoria contínua da qualidade da água para consumo Humano. Forneceu subsídios para a finalização do projeto Fapesp 00/02024-4 "Análise crítica do padrão de potabilidade das águas destinadas ao abastecimento Público: Avaliação da qualidade das águas destinadas ao abastecimento Público no estado de São Paulo", realizado em parceria com a Companhia Estadual de Saneamento Básico do Estado de São Paulo - SABESP e com o órgão ambiental do estado de São Paulo, a CETESB.

No contexto de política estadual de controle da qualidade da água das bacias hidrográficas este projeto também fornece subsídios a outro projeto Fapesp 03/01694-1 "Gerenciamento de Lodo de Estações de Tratamento de Água", realizado também em parceria com a Companhia Estadual de 
Saneamento Básico do Estado de São Paulo - SABESP e com a Escola Politécnica da USP.

\section{OBJETIVOS}

\subsection{Objetivo Geral}

Avaliar o impacto da atividade agrícola na qualidade da água da Bacia Hidrográfica do Rio Ribeira de Iguape com vistas à proteção ambiental e a saúde pública, servindo como base para a implementação e complementação das normas nacionais, de modo a assegurar inocuidade da água mediante a eliminação, redução ou ampliação do controle de substâncias tóxicas.

\subsection{Objetivos Específicos}

- Obter informações sobre a qualidade da água quanto à distribuição espacial e temporal de ocorrência e abundância de agrotóxicos na Bacia Hidrográfica do Rio Ribeira de Iguape;

- Avaliar a eficiência e a confiabilidade do sistema de tratamento, observando a salvaguarda da integridade da fonte de água bruta na bacia hidrográfica e o monitoramento adequado da água da estação de tratamento;

- Auxiliar na análise critica da legislação sobre parâmetros e padrão de potabilidade, principalmente quanto ao tema agrotóxicos;

- Realizar uma análise de risco sobre principais agrotóxicos utilizados na região;

- Caracterizar os mananciais superficiais em locais significativos do ponto de vista de captação de água para consumo humano quanto à contribuição de agrotóxico; 
- Avaliar a influência da sazonalidade no aporte das contaminações bem como as condições de caráter ambiental e econômico quanto ao uso e ocupação do solo;

- Avaliar a eficiência dos processos de tratamento aplicados nas Estações de Tratamento de Água (ETA's), para os sistemas produtores, por meio da análise da água tratada.

\subsection{Aspectos Relevantes do Trabalho}

Os agrotóxicos estão entre os principais instrumentos do atual modelo de desenvolvimento da agricultura brasileira, mas devido aos efeitos adversos que podem causar, a exposição humana e ao meio ambiente, a preocupação com esses produtos cresce em importância com o aumento das vendas.

O relatório de consumo de ingredientes ativos de agrotóxicos e afins, IBAMA 2000, contempla 284 ingredientes ativos com um consumo nacional de agrotóxicos de 131.970 toneladas. Os herbicidas ocupam posição de destaque não só entre os agrotóxicos com maior volume de comércio, como maior volume de importação e maior uso. Na lista dos dez agrotóxicos de maior consumo no país cinco são herbicidas, onde estão inclusos a atrazina e a trifluralina (PNGRQ, 2003).

O uso de agrotóxicos hoje representa um grave problema que envolve paises com diferentes graus de desenvolvimento. A OMS estima que 3 milhões de pessoas sejam contaminadas por agrotóxicos em todo o mundo, sendo $70 \%$ dos casos em paises em desenvolvimento. No Brasil, os agrotóxicos de uso agrícola estão em sétimo lugar em número de casos de acidentes com substâncias tóxicas e em primeiro lugar em número de óbitos (PNGRQ, 2003).

A introdução de substâncias tóxicas na água é uma das causas mais complexas de deterioração da qualidade da água destinada ao abastecimento público, principalmente quando se refere aos agrotóxicos, necessitando de programas de monitoramento. 
Um programa de monitoramento ambiental pode fornecer importantes informações sobre o grau de degradação ambiental, permitindo também avaliar a eficiência de ações mitigadoras adotadas. É o primeiro passo para se conhecer o funcionamento dos ecossistemas. Em relação aos agrotóxicos esse programa pode fornecer subsídios às agencias de proteção ambiental, a implementar novas leis que regulam seu uso (Frick et al 1998; Neal et al, 1998, Pires, 2004).

Nos EUA, por exemplo, um programa de avaliação da qualidade de rios e aqüíferos denominados NAWQA (National Water Quality Assessment), iniciado em 1991, abrange $70 \%$ das fontes destinadas ao abastecimento publico. Os estudos geralmente são direcionados de forma sazonal, estando os herbicidas simazina e atrazina, entre os indicadores de qualidade de água da bacia, estando este último entre os 29 poluentes prioritários estabelecidos pela EPA.

A CETESB (Companhia de Tecnologia de Saneamento Ambiental do estado de São Paulo) avalia a qualidade das águas interiores em 154 pontos de monitoramento, sendo 38 coincidentes com mananciais de abastecimento público, apesar de bem estruturado, o programa de monitoramento não contempla os principais princípios ativos comercializados no país, tendo pouca informação sobre os agrotóxicos e praticamente nenhuma pesquisa ou informação sobre a Bacia do Ribeira de Iguape.

A maioria dos estudos de monitoramento e pesquisas realizados em bacias e fontes destinadas ao abastecimento público avaliam parâmetros físicoquímicos, nutrientes, constituintes inorgânicos e avaliação microbiológica. São escassas as pesquisas em relação a agrotóxicos (Molander, 1998, Katsuóka, 2001, Marques et al 2003).

Dessa forma, a principal atividade deste trabalho foi avaliar a influência do uso de agrotóxicos da agricultura local na qualidade de água em áreas de captação na Bacia Hidrográfica do Rio Ribeira de Iguape. A literatura consultada mostrou que não existe histórico do monitoramento de agrotóxicos na bacia. Amostras de água bruta e tratada foram coletadas, durante um período anual, com coletas bimestrais, abordando principalmente dois períodos distintos, o 
período seco e o período chuvoso, em 18 estações de tratamento de água (ETA) da SABESP, pertencentes à bacia hidrográfica. Após avaliação preliminar o estudo foi direcionado para 10 estações de tratamento e seus respectivos pontos de captação na bacia.

A pesquisa também permitiu desenvolver e aplicar uma metodologia sensível e seletiva para análise multi-resíduo utilizando a extração em fase sólida (SPE) e o sistema de cromatografia líquida de alta eficiência com detecção por espectrometria de massas Tandem. 


\section{CONSIDERAÇÕES GERAIS SOBRE AGROTÓXICOS}

\subsection{Demanda de água para o uso agrícola: uma avaliação do uso de agrotóxico no Brasil.}

O crescimento da demanda mundial de água de boa qualidade, a uma taxa superior à da renovabilidade do ciclo hidrológico é consensual, previsto nos meios técnicos e científicos internacionais. Este crescimento tende a se tornar uma das maiores pressões antrópicas sobre os recursos naturais do planeta neste novo século.

Na sociedade moderna, a busca do conforto implica necessariamente num aumento considerável das necessidades diárias de água e energia. A melhoria da qualidade de vida reflete entre outras coisas, nas condições de habitação e infra-estrutura. As estatísticas da Organização Meteorológica Mundial das Nações Unidas demonstram que, nas próximas décadas, a situação global das reservas hídricas tende a piorar, consideravelmente, caso não haja ações emergentes para a melhoria da gestão da oferta da demanda d'água (OMS, 2004).

Eutrofização, metais em concentrações tóxicas, acidificação, poluentes orgânicos e efluentes tóxicos tem degradado os corpos d'água principalmente em áreas densamente povoadas. Os recursos hídricos superficiais são os primeiros a serem afetados e os responsáveis pela alteração da qualidade de vida da população dele servida. A produção de informação regionalizada descrevendo a situação dos corpos hídricos associada às alterações da cobertura vegetal dos solos para uso agrícola são parâmetros imprescindíveis aos estudos de monitoramento.

O Brasil é um país de dimensões continentais, ocupando quase $50 \%$ do território da América do Sul. Desta, 92\% está localizada na faixa tropical com um relevo relativamente baixo, isto explica a predominância de climas quentes com temperaturas médias anuais acima de $20^{\circ} \mathrm{C}$. Em função da variação geomorfológica e climática este apresenta grande diversidade de biomas. 
Podemos verificar a existência de climas muito distintos, como por exemplo, regiões onde o calor e a chuva são constantes - Floresta Amazônica (temperatura média anual é de $26^{\circ} \mathrm{C}$ e $27^{\circ} \mathrm{C}$ ), assim como regiões onde o clima é quente e sem chuvas durante a maior parte do ano - Caatinga (ANA, 2002 e 2003).

O país é dividido político-administrativamente em cinco regiões: Norte, Nordeste, Sudeste, Centro-Oeste e Sul. Possuindo 26 Estados e 1 Distrito Federal. Destarte, para o Plano Nacional de Gerenciamento de Recursos Hídricos adotou-se a divisão do País em regiões hidrográficas. Dentro do espírito da Lei das Águas (Lei $n^{0}$ 9.433/MMA/97), dividiu-se o Brasil em 13 regiões hidrográficas (Resolução $n^{0}$ 30/CNRH/02). As Regiões Hidrográficas ou Unidades Hidrográficas da Referência (UHR), proposta para o Plano Nacional de Recursos Hídricos PNRH em primeiro nível, são: Amazonas, Costeira do Leste, Costeira do Norte, Costeira do Sudeste, Tocantins, Costeira do Sul, Costeira do Nordeste Ocidental, Uruguai, Parnaíba, Paraná, Costeira do Nordeste Oriental, Paraguai e São Francisco (ANA, 2002 e 2003).

Apesar da situação aparentemente favorável, observa-se uma enorme desigualdade regional na distribuição dos recursos hídricos. Quando se comparam essas situações com a abundância de água da Bacia Amazônica, que corresponde às regiões Norte e Centro-Oeste, contrapondo-se a problemas de escassez no Nordeste e conflitos de uso nas regiões Sul e Sudeste, a situação se agrava. Ao se considerar, em lugar de disponibilidade absoluta de recursos hídricos renováveis, àquela relativa à população dele dependente, o Brasil deixa de ser o primeiro e passa ao vigésimo terceiro no mundo (Projeto Água, 2003). Na TAB.1 são apresentados os dados da disponibilidade e demanda de água das regiões Hidrográficas Brasileiras.

As informações apresentadas na TAB.1 mostram que a maior demanda de água no país é exercida pela agricultura, especialmente pela irrigação, com quase $56 \%$ de toda demanda; seguida pelo uso urbano $21 \%$, indústrial $12 \%$, rural $6 \%$ e animal $5 \%$. Observa-se que existem grandes diferenças entre as regiões hidrográficas com relação à disponibilidade hídrica e demanda. 
A região Hidrográfica Amazonas, por exemplo, apresenta a maior área e mais de $80 \%$ da disponibilidade hídrica do país, e com um baixo índice populacional, resultando em uma demanda hídrica baixa de apenas $0,1 \% \mathrm{em}$ relação a sua disponibilidade. Situação exatamente inversa ocorre na região Costeira Hidrográfica NE Oriental, onde uma população alta $(12,74 \%)$ está concentrada em uma área pequena $(3,37 \%)$ com disponibilidade hídrica menor que $0,05 \%$ da disponibilidade nacional e uma demanda hídrica de $101 \%$ em relação a sua disponibilidade.

As regiões Hidrográficas do Paraná e Costeira Sudeste apresentam, neste sentido, um perfil semelhante à região Costeira NE Oriental com alta concentração populacional e alta demanda hídrica, mas nestas não é a baixa disponibilidade hídrica e sim o uso intensivo dos recursos hídricos que leva a uma defasagem na disponibilidade. Outro fator que influencia na disponibilidade é a degradação da qualidade da água, isto ocorre devido ao alto grau de industrialização e urbanização, a falta de saneamento e a poluição difusa decorrente da agricultura.

\subsection{A agropecuária brasileira}

O Brasil ocupa o sétimo lugar no "ranking" mundial dos principais países exportadores de produtos agrícolas (FAO). É citado pela FAO (Organização das Nações Unidas para Agricultura e Alimentação) como um dos países que mais utilizam agrotóxicos, principalmente na horticultura, ocupando a oitava posição mundial, entre os países consumidores de agrotóxicos. No total de vendas de agrotóxicos no Brasil, o Estado de São Paulo tem a maior participação, seguida pelo Paraná, Rio Grande do Sul, Mato Grosso, Minas Gerais, Goiás e Mato Grosso do Sul, como mostra a FIG.1. 
TABELA 1 - Disponibilidade e Demanda de Água das Regiões Hidrográficas Brasileiras (ANA, 2003).

\begin{tabular}{|c|c|c|c|c|c|c|c|c|c|c|c|c|c|}
\hline \multirow{3}{*}{$\begin{array}{l}\text { Região } \\
\text { Hidrográfica }\end{array}$} & \multirow{3}{*}{$\begin{array}{l}\text { Pop. } \\
\text { (hab) }\end{array}$} & \multirow{3}{*}{$\begin{array}{l}\text { Área } \\
\left(\mathrm{km}^{2}\right)\end{array}$} & \multirow{3}{*}{$\begin{array}{c}\mathrm{Q}_{95} \\
\left(\mathrm{~m}^{3} \mathrm{~s}^{-1}\right)\end{array}$} & \multirow{3}{*}{$\begin{array}{c}\mathrm{P} \\
(\mathrm{mm})\end{array}$} & \multirow{3}{*}{$\begin{array}{c}\begin{array}{c}\text { Etr/P } \\
(\%)\end{array} \\
(\mathrm{mm})\end{array}$} & \multicolumn{7}{|c|}{ Demandas $\left(\mathrm{m}^{3} \mathrm{~s}^{-1}\right)$} & \multirow{3}{*}{$\begin{array}{c}\text { Dem.I } \\
\text { QQ }_{\text {ref. }}^{(2)} \\
\text { (\%) }\end{array}$} \\
\hline & & & & & & \multicolumn{3}{|c|}{ Humana } & \multirow{2}{*}{ Anim. } & \multirow{2}{*}{ Ind. } & \multirow{2}{*}{ Irrig. } & \multirow{2}{*}{ Total } & \\
\hline & & & & & & Urb. & Rural & Total & & & & & \\
\hline Amazonas $^{(1)}$ & 7.550 .526 & 3.760 .706 & 64.734 & 2.234 & 59 & 10,8 & 11,3 & 22,1 & 13,2 & 3,3 & 23,8 & 62,4 & 0,1 \\
\hline Cost Norte & 58.898 & 82.696 & 432 & 2.447 & 47 & 0,03 & 0,1 & 0,2 & 0,1 & 0,0 & 0,0 & 0,3 & 0,1 \\
\hline Tocantins & 7.890 .714 & 967.060 & 3.377 & 1.869 & 73 & 9,3 & 8,9 & 18,2 & 16,3 & 2,1 & 47,7 & 84,3 & 2 \\
\hline Cost NE Oci & 4.742 .431 & 254.100 & 233 & 1.738 & 82 & 4,7 & 5,5 & 10,3 & 2,5 & 0,6 & 2,8 & 16,2 & 7 \\
\hline Parnaíba & 3.630 .431 & 334.113 & 294 & 1.119 & 94 & 3,2 & 2,9 & 6,0 & 2,3 & 0,4 & 15,4 & 24,0 & 8 \\
\hline Cost. NE Ori. & 21.606 .881 & 287.348 & 36 & 1.132 & 92 & 37,0 & 17,1 & 54,1 & 4,2 & 14,2 & 173,6 & 246,2 & 101 \\
\hline São Francisco & 12.823 .013 & 638.323 & 1.077 & 1.036 & 86 & 35,3 & 8,7 & 44,1 & 7,8 & 12,9 & 138,2 & 203,0 & 16 \\
\hline Cost do Leste & 13.641 .045 & 374.677 & 241 & 1.053 & 89 & 32,1 & 13,5 & 45,7 & 7,1 & 4,2 & 34,7 & 91,7 & 38 \\
\hline Cost. Sudeste & 25.644 .396 & 229.972 & 1.012 & 1.339 & 66 & 90,4 & 19,0 & 109,3 & 5,2 & 32,1 & 72,1 & 218,8 & 22 \\
\hline Cost. do Sul & 11.592 .481 & 185.856 & 623 & 1.573 & 55 & 33,6 & 8,0 & 41,6 & 5,8 & 33,7 & 292,7 & 373,7 & 60 \\
\hline Uruguai & 3.834 .652 & 174.612 & 806 & 1.784 & 58 & 7,1 & 3,6 & 10,7 & 7,2 & 5,9 & 221,1 & 245,0 & 30 \\
\hline Paraná & 54.639 .523 & 879.860 & 4.323 & 1.511 & 75 & 190,7 & 22,8 & 213,6 & 34,6 & 146,0 & 195,5 & 589,6 & 14 \\
\hline Paraguai & 1.887 .401 & 363.477 & 687 & 1.398 & 89 & 3,6 & 1,2 & 4,9 & 8,8 & 1,1 & 8,1 & 22,8 & 3 \\
\hline Brasil & 169.542 .392 & 8.532 .770 & 77.873 & 1.800 & 67 & 457,9 & 122,6 & 580,5 & 115,1 & 256,7 & 1225,6 & 2177,9 & 3 \\
\hline
\end{tabular}


O setor agropecuário brasileiro contribui com cerca de 7,6 \% na formação do Produto Interno Bruto (PIB), o que corresponde a R\$ 86 bilhões (valores do ano base de 2000). Utilizando-se o conceito atual de agro-negócio (que considera desde 0 produto primário até sua industrialização e comercialização, incluindo os setores fornecedores de insumos, máquinas e implementos), a geração de renda do setor é cerca de $26 \%$ do PIB, ou seja, perto de $\mathrm{R} \$ 306,86$ bilhões.

A atividade rural emprega cerca de $24 \%$ de toda a população economicamente ativa, pouco mais de 16,6 milhões de trabalhadores, sendo o segmento que mais emprega no Brasil. O desempenho da agricultura, isoladamente, pode ser avaliado pelas safras de grãos, especialmente soja, milho, arroz, feijão e trigo, com volumes da ordem de 80 milhões de toneladas/ano.

O número de pessoas ocupadas com o setor agropecuário (IBGE, ano base de 1999) foi de 17.372.105, destacando-se como principais produtos: arroz, cana-de-açúcar, milho, cacau, feijão, banana, café, laranja, soja, algodão; aves e bovinos. Seguido pelo setor da indústria, com 13.804.961 pessoas ocupadas e o comércio com 9.618.374 pessoas ocupadas, sendo superado somente para o setor de serviços (30.880.779 pessoas ocupadas).

O setor agropecuário tem ampliado, de maneira substancial, sua participação na pauta de exportações do país, proporcionando uma receita cambial em torno de US\$ 19 bilhões por ano, representando 33\% das vendas brasileiras ao exterior.

Este registra, atualmente, um superávit na balança comercial de cerca de US\$ 14,5 bilhões/ano, sendo o único setor da economia a apresentar resultados positivo num período recente, o que atesta sua competitividade e importância na geração de divisas para o país (PNGSQ, 2003).

O consumo nacional de agrotóxicos em 2000 foi de 131.970 toneladas. Sendo incluídos neste montante, além dos herbicidas, os inseticidas, fungicidas e ascaricidas, os reguladores de crescimento, feromônios, bactericidas e 
moluscicidas. O consumo de afins de agrotóxicos, denominados de produtos atípicos (enxofre, óleo mineral, cobre, óleo vegetal, adjuvante e espalhante adesivo) foi de 30.491 toneladas.

Na FIG.1 temos listado o consumo de agrotóxicos por estado brasileiro segundo os dados do Sindicato Nacional da Indústria de Produtos para Defesa Agrícola (SINDAC) órgão que atualmente disponibiliza a maior parte dos dados estatísticos do setor. Entres os dez agrotóxicos de maior consumo no país, no ano de 2000, o glifosato, está em primeiro lugar, seguido pelo enxofre e a atrazina. Na TAB.2 são apresentados os dez agrotóxicos com maior volume de consumo (ano base 2000).

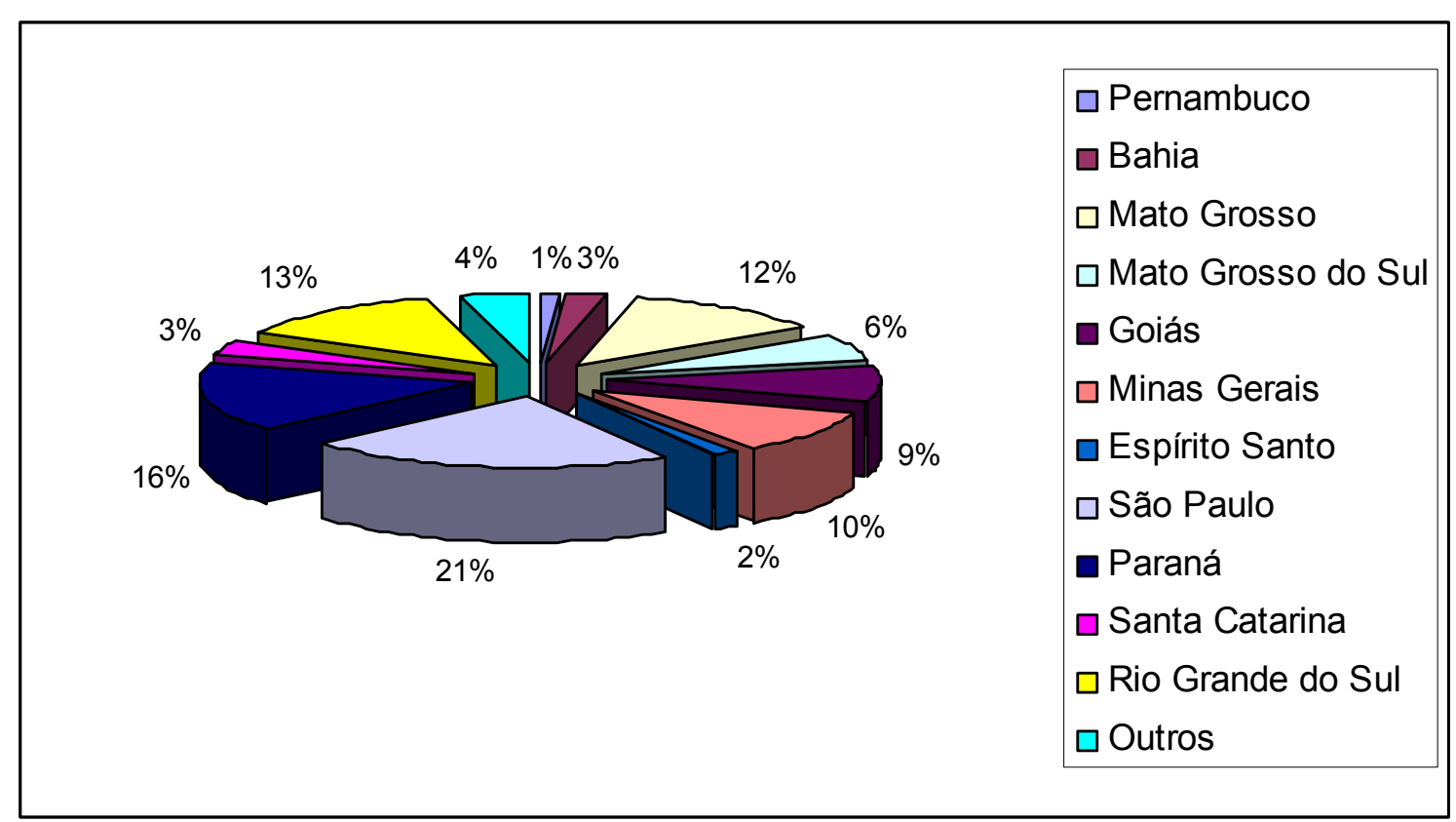

FIGURA 1 - Consumo de agrotóxico por Estado, no Brasil (ano base 2000 SINDAG, 2002; adaptado por Marques, M.N.)

O comércio mais significativo em termos de vendas é o de herbicidas, que no período de 1999 a 2001, oscilou entre 48 e $50 \%$ do total de vendas destes anos (FIG.2) (Ministério da Agricultura, 2004; SINDAG, 2004). 
TABELA 2 - Relação dos dez agrotóxicos listados com maior volume de consumo no País, dados de 2000 (IBAMA, 2000; PNGSQ. 2003).

\begin{tabular}{ccc}
\hline Ingrediente Ativo & Classe de uso & $\begin{array}{c}\text { Consumo } \\
\text { Nacional }(\mathrm{t})\end{array}$ \\
\hline Glifosato & Herbicida & $39.515,248$ \\
\hline Enxofre & Acaricida & $11.924,971$ \\
\hline Atrazina & Herbicida & $9.641,942$ \\
\hline $\begin{array}{c}\text { 2,4-D(Amina, éster, Triet, } \\
\text { picloram) }\end{array}$ & Herbicida & $9.016,003$ \\
\hline Óleo Mineral & $\begin{array}{c}\text { Acaricida, Adjuvante, } \\
\text { Fungicida e lseticida }\end{array}$ & $8.618,376$ \\
\hline Sulfosate & Herbicida & $6.395,510$ \\
\hline Mancozeb & Fungicida & $5.434,920$ \\
\hline Endosulfan & Inseticida & $5.346,629$ \\
\hline Oxicloreto de Cobre & Fungicida & $4.484,423$ \\
\hline Trifluralina & Herbicida & $3.313,580$ \\
\hline
\end{tabular}

Os herbicidas ocupam posição de destaque não só entre os agrotóxicos com maior volume de comércio, mas também estão entre os agrotóxicos com maior volume de importação. Entre os fungicidas o hidróxido de cobre representa aproximadamente $50 \%$ do valor do item agregado, em segundo lugar aparecem os fungicidas a base de Mancozeb ou de Maneb. A tendência observada nos últimos quatro anos, quanto à comercialização de agrotóxicos, foi o aumento do número de produtos classe III e IV e um comportamento mais estável no número de produtos das classes I e II disponíveis no mercado, como pode ser observado na FIG.3. 


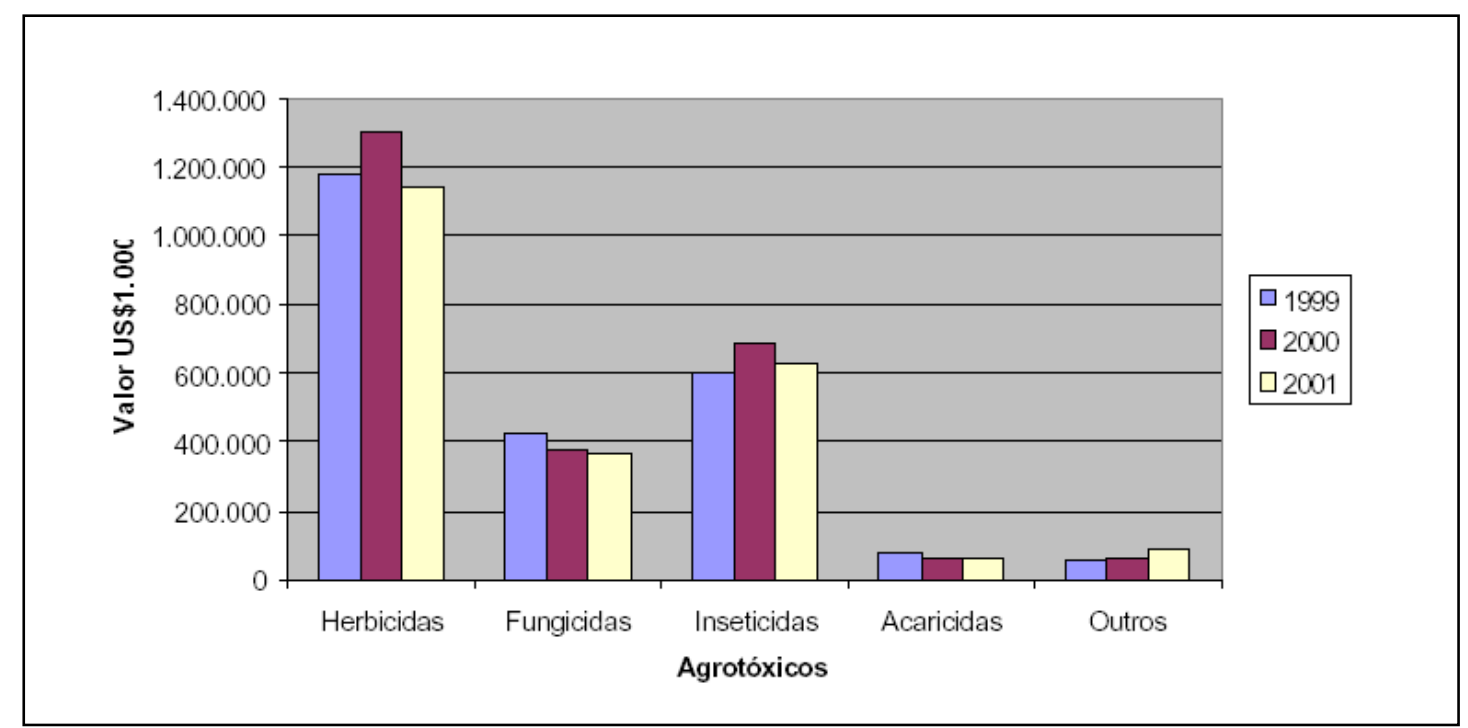

FIGURA 2 - Perfil da venda de agrotóxicos no Brasil no período de 1999 a 2001 (SIDAG, 2001).

Esta classificação é feita segundo recomendações da Portaria Interministerial MA/MS nํ2 220, de 14/03/79. Essa tem importância fundamental na aplicação do Receituário Agronômico, uma vez que padroniza a rotulagem, orienta o uso seguro e adequado pelos agricultores, facilita a classificação e a visualização dos produtos segundo o seu grau de toxidez (Compêndio de defensivos agrícolas,1996). A rotulagem obedece a seguinte classificação:

- Classe I - altamente tóxico - com cor da tarjeta em vermelho;

- Classe II - medianamente tóxico - com cor da tarjeta em amarelo;

- Classe III - pouco tóxico - com cor da tarjeta em azul;

- Classe IV - praticamente não-tóxico - com cor da tarjeta em verde. 


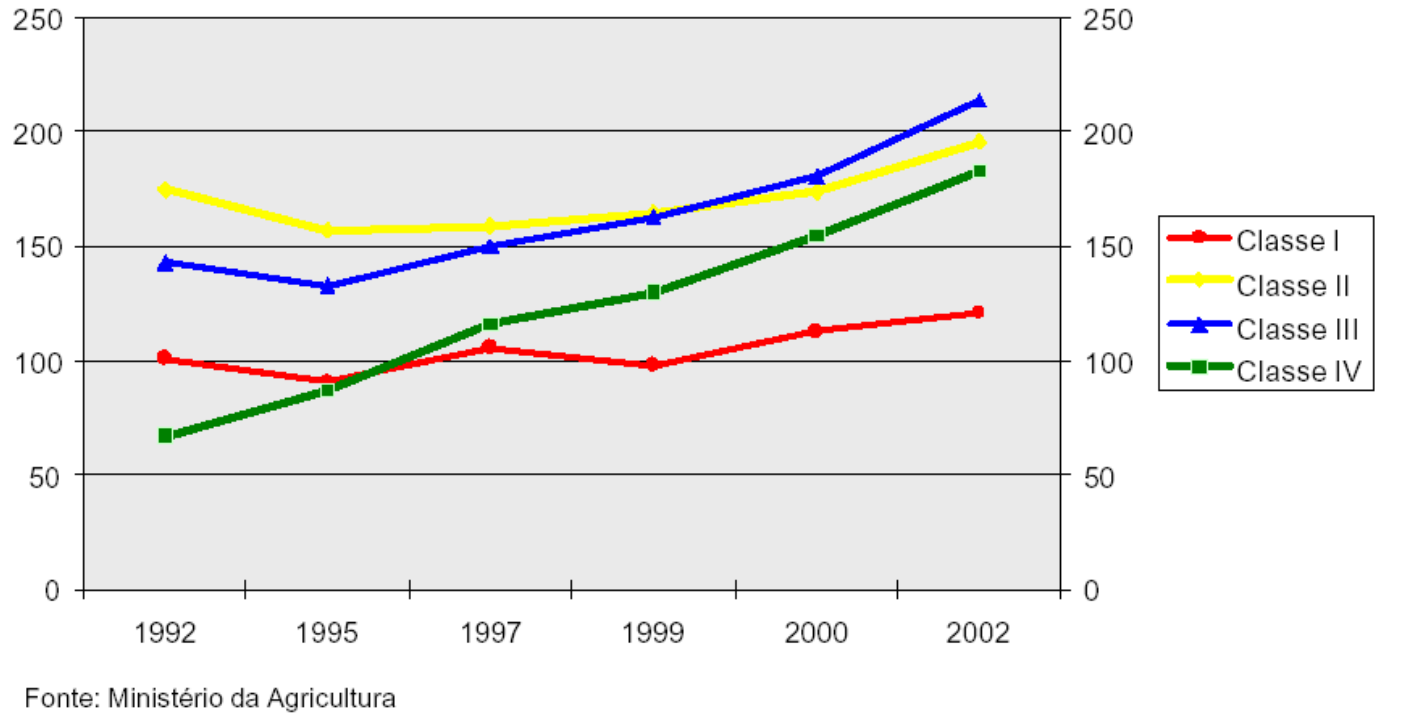

Figura 3 - Agrotóxicos comercializados por classe toxicológica no Brasil no período de 1992 a 2002 (SINDAG, 2004).

Uma avaliação realizada a partir do banco de dados do Sindicato Nacional da Indústria de Produtos para Defensivos Agrícolas (2004), FIG.4, permitiu observar que o consumo geral de agrotóxicos no Brasil, no período de 1997 a 2000, foi muito mais acentuado nas culturas de soja, milho, citrus, canade-açúcar, café, algodão, arroz, batata-inglesa e feijão.

Dos estados brasileiros o estado de São Paulo é líder no volume de vendas e de uso de agrotóxico, apesar de ser o terceiro estado brasileiro em área plantada (FIG.5). Caracteriza-se por possuir a mais diversificada e intensa produção agrícola do país, significando o uso de grande quantidade de agrotóxicos, fertilizantes e de alta tecnologia nas atividade, atingindo elevados índices de produtividade (Katsuóka, 2001; IBGE, 1997). 


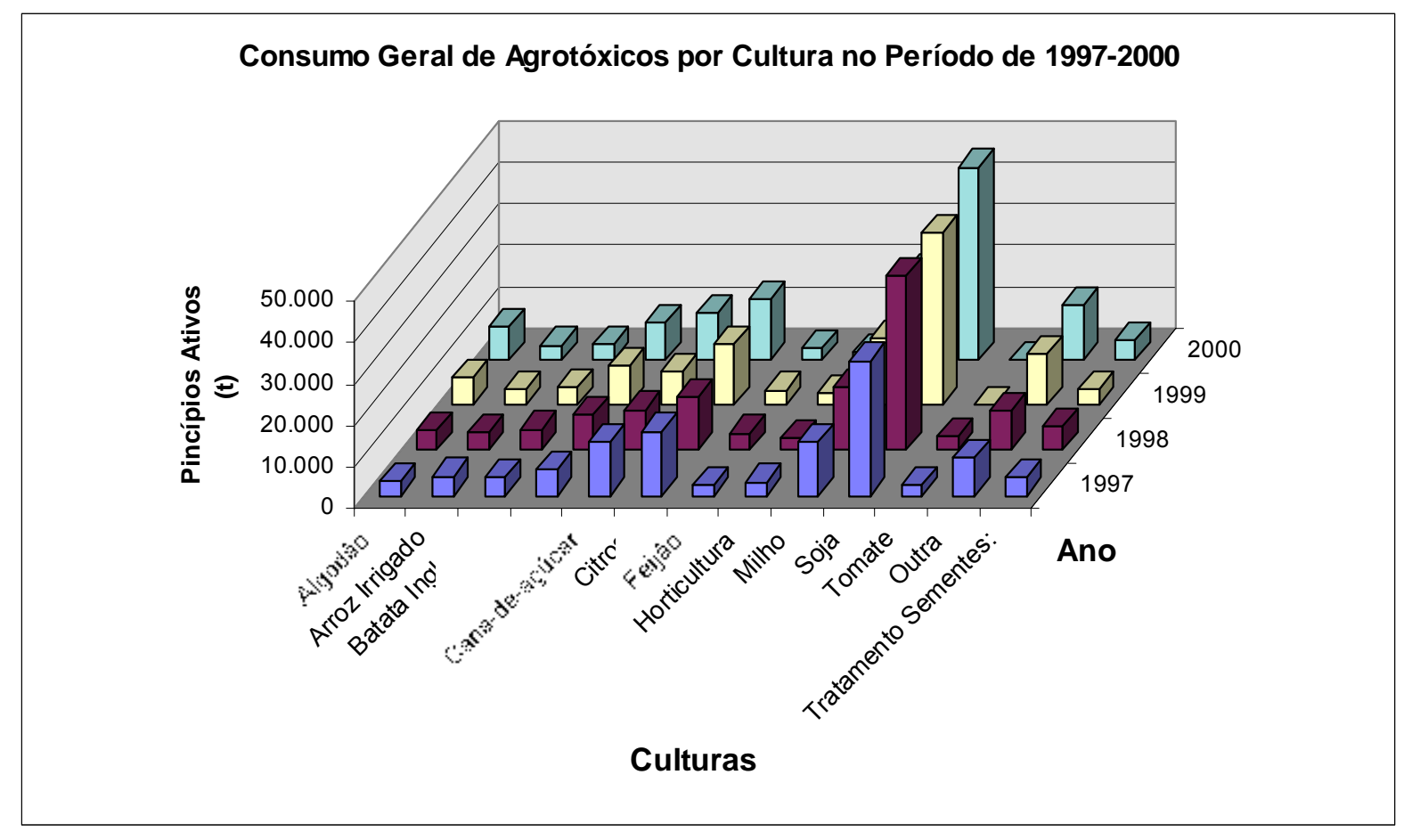

FIGURA 4 - Média do consumo de agrotóxico por cultura no Brasil no período de 1997 - 2000 (SINDAG, 2002; adaptado por Marques, M.N.).

Estima-se que $43,5 \%$ da demanda de água do Estado é usada para atender à agricultura, contra $31,8 \%$ para a indústria e $24,7 \%$ para o abastecimento público. Cerca de $85,2 \%$ da água do Estado está associada ao uso agrícola do solo. $\mathrm{O}$ alto padrão tecnológico predominante na agricultura do Estado pode se observado por meio dos indicadores agropecuários (IBGE, 1997): 91,5\% das lavouras usam fertilizantes; mais de $81 \%$ destas fazem o controle de pragas e na pecuária e $13,4 \%$ dos estabelecimentos faz uso da irrigação, correspondendo a 40 regionais agrícolas, produzindo 213 tipos de culturas diferentes.

O potencial hídrico superficial do estado de São Paulo é de $3.140 \mathrm{~m}^{3} \mathrm{~s}^{-1}$ podendo dispor de $2.015 \mathrm{~m}^{3} \mathrm{~s}^{-1}$. A atual demanda total de água para a irrigação no Brasil é da ordem de $1.226 \mathrm{~m}^{3} \mathrm{~s}^{-1}$, a qual, apresenta uma distribuição de, aproximadamente, $33 \%$ para a região sul; $31 \%$ para a sudeste e $24,5 \%$ para o nordeste (Telles, 1999; ANA, 2003; CATI, 2001). 


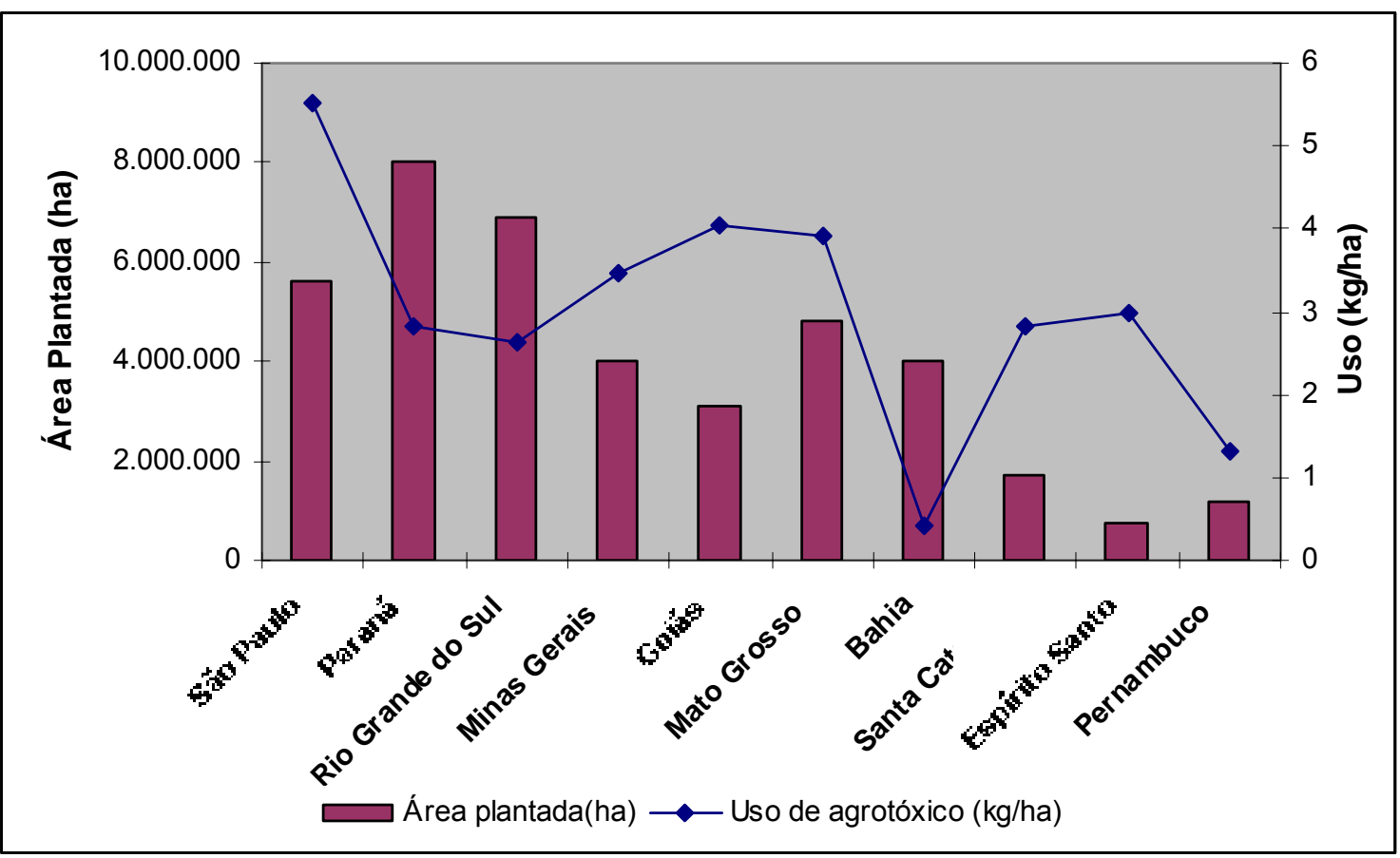

FIGURA 5 - Uso de Agrotóxicos $\left(\mathrm{kgha}^{-1}\right)$ e área plantada (ha) (Fontes: SINDAG, 2002; IBGE, 2002).

Um levantamento de unidades de produção agrícola, realizado pelo projeto LUPA, contabilizou os dados estatísticos do IBGE, levantados no período de1995 a 1996, das culturas que possuem maior área cultivada por hectares no Estado de São Paulo. Na FIG.6 apresentam-se as maiores áreas cultivadas por hectares, em ordem decrescente.

As culturas são: braquiária, cana-de-açúcar, milho, laranja, soja, eucalipto, capim-colonião, café, feijão, algodão, pinus, capim - napier, capim jaraguá, amendoim, banana, arroz, seringueira, sorgo, limão, mandioca, manga e tangerina. 


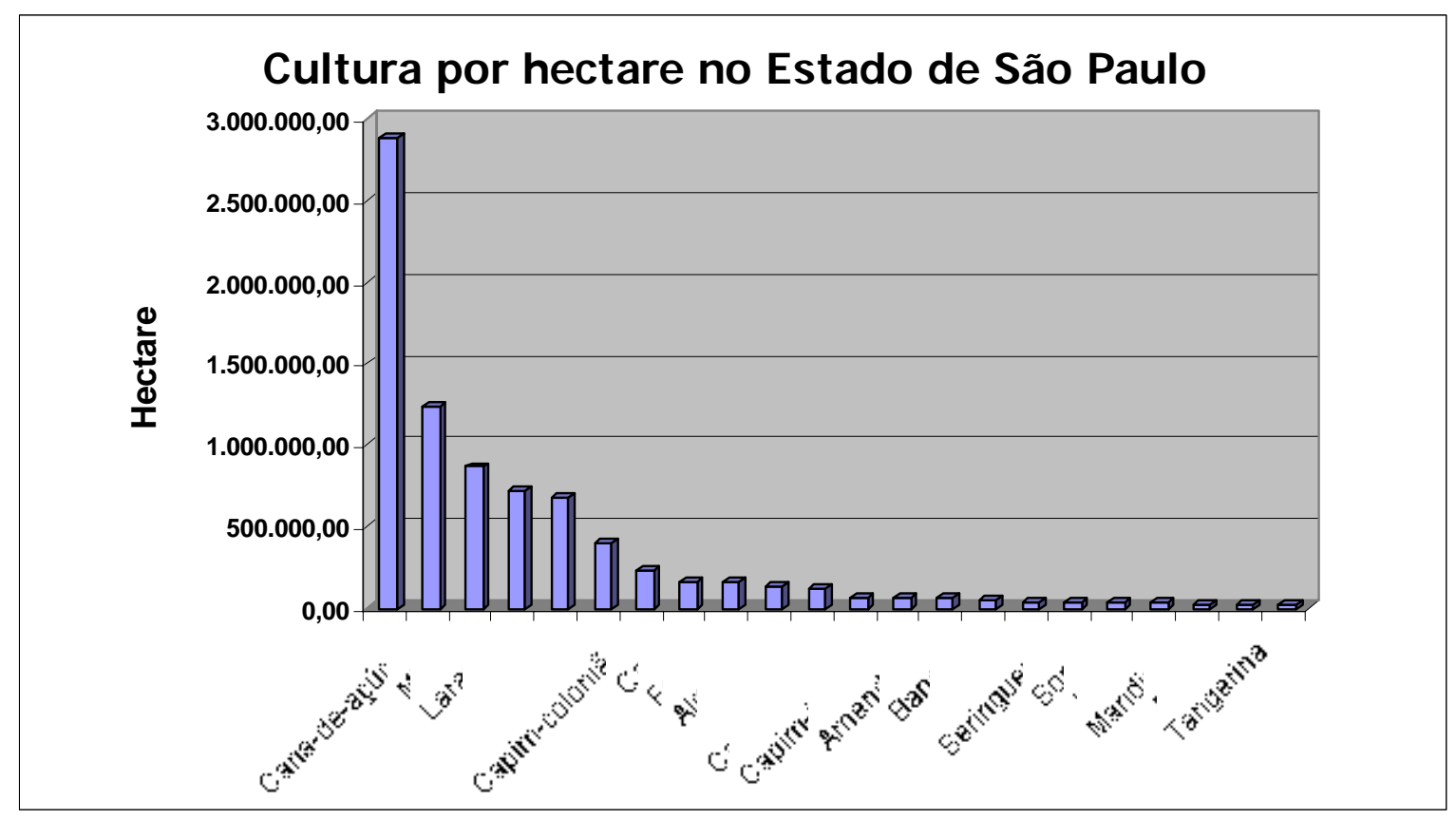

FIGURA 6 - Área de Cultura por Hectare, no Estado de São Paulo (IBGE, 1997 - adaptado por Marques, M.N.).

\subsection{Agrotóxicos e qualidade de água}

O uso de agrotóxico representa hoje um grave problema que envolve países com diferentes graus de desenvolvimento. A OMS estima que três milhões de pessoas sejam contaminadas por agrotóxicos em todo o mundo, sendo que $70 \%$ dos casos em países em desenvolvimento.

O Brasil é considerado um dos maiores consumidores de agrotóxicos do mundo. Segundo o Sistema de Informações Tóxico-Farmacológicas, o SINITOX, no ano de 2001 foram registraddos 2.690 casos de intoxicação humana por agrotóxico de uso agrícola, com 91 óbitos registrados. Os agrotóxicos de uso agrícola estão em sétimo lugar em número de casos de acidentes com substâncias tóxicas, perdendo só com relação a intoxicação por medicamentos, porém em primeiro lugar em número de óbitos (TAB.3) (PNGSQ, 2003). 
TABELA 3 - Intoxicação humana por agentes tóxicos (PNGSQ, 2003).

\begin{tabular}{|c|c|c|c|c|c|c|c|c|c|c|c|c|c|}
\hline \multirow[t]{2}{*}{ Agentes } & \multirow{2}{*}{$\begin{array}{c}\text { Total de } \\
\text { Casos } \\
\text { Registra } \\
\text { dos. } \\
\text { (\%) }\end{array}$} & \multirow{2}{*}{$\begin{array}{c}\text { Núm. } \\
\text { Óbitos }\end{array}$} & \multicolumn{3}{|c|}{$\begin{array}{c}\text { Zona de } \\
\text { Ocorrência dos } \\
\text { casos }\end{array}$} & \multicolumn{5}{|c|}{$\begin{array}{c}\text { № Casos por Regiões do } \\
\text { Pais } \\
\text { (óbitos) }\end{array}$} & \multicolumn{3}{|c|}{$\begin{array}{l}\text { №- Casos por } \\
\text { circunstância } \\
\text { Acidente }\end{array}$} \\
\hline & & & Rural & Urb. & Ign. & $\mathrm{N}$ & NE & SE & $\mathrm{s}$ & $\mathrm{CO}$ & Ind. & Col. & Amb. \\
\hline $\begin{array}{l}\text { Agrotóxicos (uso } \\
\text { Agrícola) }\end{array}$ & $\begin{array}{c}2.690 \\
(5,96 \%)\end{array}$ & 91 & 989 & 1625 & 76 & - & $\begin{array}{l}189 \\
(28)\end{array}$ & $\begin{array}{l}375 \\
(4)\end{array}$ & $\begin{array}{c}1880 \\
(45)\end{array}$ & $\begin{array}{l}246 \\
(14)\end{array}$ & 824 & 51 & 24 \\
\hline $\begin{array}{l}\text { Agrotóxicos (uso } \\
\text { Doméstico) }\end{array}$ & $\begin{array}{c}1.583 \\
(3,51 \%)\end{array}$ & 2 & 65 & 1477 & 41 & 8 & $\begin{array}{l}132 \\
(1)\end{array}$ & 689 & $\begin{array}{c}622 \\
(1)\end{array}$ & 132 & 898 & 39 & 11 \\
\hline Raticidas & $\begin{array}{c}2.744 \\
(6.08 \%)\end{array}$ & 31 & 206 & 2500 & 38 & 7 & $\begin{array}{l}740 \\
(22)\end{array}$ & $\begin{array}{c}992 \\
(3)\end{array}$ & $\begin{array}{c}856 \\
(3)\end{array}$ & $\begin{array}{l}149 \\
(3)\end{array}$ & 1012 & 20 & 3 \\
\hline Domissanitários & $\begin{array}{c}4.131 \\
(9,15 \%)\end{array}$ & 6 & 41 & 4033 & 57 & 11 & $\begin{array}{r}277 \\
(3)\end{array}$ & $\begin{array}{c}1.84 \\
7\end{array}$ & $\begin{array}{c}1834 \\
(3)\end{array}$ & 162 & 3429 & 27 & 3 \\
\hline $\begin{array}{l}\text { Produtos } \\
\text { Químicos } \\
\text { Industriais }\end{array}$ & $\begin{array}{c}2.635 \\
(5,84 \%)\end{array}$ & 8 & 66 & 2506 & 63 & 9 & $\begin{array}{l}186 \\
(1)\end{array}$ & $\begin{array}{r}707 \\
(2)\end{array}$ & $\begin{array}{c}1521 \\
(5)\end{array}$ & 212 & 1736 & 62 & 13 \\
\hline Metais & $\begin{array}{c}219 \\
(0,49 \%)\end{array}$ & - & 4 & 210 & 5 & 1 & 3 & 20 & 184 & 11 & 153 & 5 & 3 \\
\hline
\end{tabular}

Fonte: MS/FIOCRUZ/SINITOX.

Reg. = registrados; Urb. = urbana; Ign. = ignorados; Ind. = industrial; Col. = coletivo; Amb. = ambiental; $\mathrm{N}=$ Norte; $\mathrm{NE}=$ Nosdeste; $\mathrm{SE}=$ Sudeste; $\mathrm{S}=$ Sul e $\mathrm{CO}=$ Centro Oeste.

A constante utilização dos recursos hídricos e a introdução de substâncias tóxicas nos ecossistemas aquáticos têm requerido um maior número de estudos para avaliar e manter a sua qualidade.

A qualidade da água pode ser definida como sendo um conjunto das características, físicas, químicas e biológicas de um certo corpo d’água, cujos critérios de avaliação da qualidade dependem do propósito do uso (Pires et al, 2001).

Um dos grandes desafios para um programa de monitoramento da qualidade da água na bacia é conhecer o funcionamento do ecossistema, organizar um banco de dados sobre a qualidade da água e entender os fatores que afetam a qualidade regionalmente e nacionalmente (Pires, 2004).

Nos Estados Unidos, por exemplo, a U.S.Geological Survey e o U.S. Departament of the Interior estabeleceram um programa de avaliação da qualidade de rios e aquíferos denominado NAWQA (National Water Quality 
Assessment). Iniciado em 1991, abrange aproximadamente a metade dos Estados Unidos incluindo $70 \%$ das fontes destinadas ao abastecimento público. (Berndt et al, 1998).

Em relação aos agrotóxicos, o programa está fornecendo subsídios para a Agência de Proteção Ambiental Americana a implementar novas leis que regulam o uso de agrotóxicos nos EUA. Dentre as unidades estudadas no programa destacam-se os estudos realizados nas Georgia, Alabama e Flórida, no período de 1992 a 1995 (Frick et al, 1998).

Em 1994, foi iniciado na Grã-Bretanha o Programa LOIS (Land Ocean Interaction Study) com o objetivo de estudar as influências dos centros populacionais, agricultura e indústria nos rios que deságuam no Mar do Norte. Esse programa conta com a colaboração de universidades e agências ambientais da Inglaterra, País de Gales e Escócia (Neal et al., 1998).

Os estudos são direcionados de modo sazonal, sendo os principais indicadores da qualidade da bacia: $\mathrm{pH}$, alcalinidade, oxigênio dissolvido, condutividade, clorofila, fluxo, metais e compostos inorgânicos (maiores, menores e nível traço: boro, bário, ferro, manganês, níquel, molibdênio, chumbo, estrôncio, alumínio, escandio, zinco, sódio, potássio, cálcio, lítio, cobre, fósforo, nitrito, nitrato, sulfato, cobalto, cromo,...), herbicidas ( clortoluton, diuron, isoproturon, mecoprop, MCPA, MCPB, 2,4-D, atrazina, simazina e propazina) organoclorados, analisados na água e no sedimento (Neal et al, 2000a ; 2000b). Entre os agrotóxicos mais estudados estão os organoclorados e os herbicidas simazina, antrazina, isoprotuon, diuron e 2-4 D.

Durante o período de abril a setembro de 1995 a U.S.Geological Survey realizou estudos ao longo do vale do rio Mississippi para determinar 49 agrotóxicos e seus produtos de degradação em amostras de ar e de água de chuva em áreas urbanas e agrícolas. Entre os agrotóxicos determinados em altas concentrações são citados: o metil paration, diazinon e clorpirofós. Após duas décadas da proibição do uso de p,p'-DDT nos Estados Unidos, este composto e seu produto de degradação, p, $p^{\prime}$-DDE, foram encontrados nas amostras de ar. Os 
agrotóxicos atrazina, dactal e seus produtos de degradação foram encontrados com maior freqüência nas amostras de água de chuva do ponto de coleta controle, indicando a extensa faixa de transporte atmosférico destes compostos (Coupe et al, 2000; Majewski et al, 2000 e Foreman et al, 2000).

A Agência Ambiental Americana, na publicação Water Quality Guidance for the Great Lakes System, estabeleceu critérios para a qualidade da água para 29 poluentes. Esses critérios foram designados em termos de proteção à vida aquática, à vida selvagem (terrestre) e à saúde humana. Os PCBs (bifenilas policloradas), o trans-nonachlor (componente do chlrodano), a atrazina e o mercúrio foram incluídos por serem frequentemente utilizados na agricultura e causadorem danos a organismos aquáticos e terrestres, pois são bioacumulativos, persistentes e cancerígenos (EPA, 2001).

O relatório da Agência de Proteção Ambiental dos Estados Unidos sobre a qualidade das águas dos rios americanos mostra que as atividades agrícolas são as principais fontes de poluição dos rios, provocando o aumento de sedimentação, nutrientes, agrotóxicos e matéria orgânica nos rios (Katsuóka, 2001).

Os agrotóxicos, devido às suas propriedades, foram e são largamente utilizados e o seu uso tem contribuído muito para o aumento do rendimento agrícola e maior abundância de alimentos. Contudo, pouca atenção foi dada por ocasião do seu aparecimento, principalmente quanto ao aspecto toxicológico e implicações do seu uso. De acordo com Hayes \& Laws (1997) as principais vias de contaminação ambiental por agrotóxicos são: aplicação direta na água; lixiviação do solo de áreas contaminadas; contaminação de águas subterrâneas por percolação do solo; liberação de efluentes industriais; usos domésticos e despejos de materiais de descarte.

$\mathrm{Na}$ literatura internacional são inúmeros os trabalhos associados a esse tema, abordando também novas metodologias de determinação dos agrotóxicos. Na sua maioria estes métodos associam a extração em fase sólida (SPE) a cromatografia gasosa ou líquida (Barceló et al, 1992; Barceló, 1993; 
Barceló, 1993a; Biziuk, 1996; Balinova, 1996; Albanis et al, 1998; Azevedo et al, 2000; Hostetler et al, 2000; Sabik et al, 2000; Dijkman et al, 2001; Hernández et al, 2001; Quintana et al, 2001; Bossi et al, 2002;).

Recentemente Katsuóka (2001) realizou uma revisão bibliográfica sobre o desenvolvimento dos estudos de monitoramento da qualidade da água e sedimento em bacias hidrográficas, entre eles os estudos de monitoramento de herbicidas relacionados com o Programa LOIS (Land Ocean International Study), - Programa NAWQA e poucas pesquisas realizadas no Brasil, destacando o programa realizado pela CETESB.

A maioria dos estudos de monitoramento e pesquisas realizados em bacias ou microbacias hidrográficas e fontes destinadas ao abastecimento público no Brasil avaliam as mudanças, espacial e temporal, na qualidade da água do rio ou bacia em relação aos parâmetros físico-químicos, nutrientes, alcalinidade, contribuintes inorgânicos e avaliação microbiológica. Os estudos são muito escassos em relação aos agrotóxicos (Molander \& Moraes, 1998; Katsuoka et al, 2000, Marques et al, 2003).

Não existem informações, históricas e recentes, nos "Relatórios de Qualidade das Águas Interiores do Estado de São Paulo" (CETESB, 2004) sobre o monitoramento de agrotóxicos como indicadores de qualidade das águas nas bacias e muito pouca informação a respeito da UGRHI-11 (Unidade de Gerenciamento de Recursos Hídricos), o que existe são informações e pesquisas isoladas.

Oubiña et al (1988) monitoraram inseticidas e fungicidas como: clorotalonil, metalaxyl, metil paration e folpet em amostras de sedimento e água do Paty dos Alferes no Estado do Rio de Janeiro. Molander \& Moraes (1998) avaliaram baixas concentrações de clorotalonil e permetrina em amostras de águas e peixes coletadas no Parque Estadual do Alto do Ribeira - PETAR.

Katsuóka (2001) detectou a presença de aldicarbe, trifluralina, atrazina e simazina nas Bacias Hidrográficas dos Rios Mogi - Guaçú e do Rio Pardo. 
Foram avaliadas a qualidade da água e sedimento em dez microbacias destinadas a captação de água para abastecimento público, no período de junho de 1999 a junho 2000. Foram identificados, utilizando espectrometria de massas associada a cromatografia gasosa, mais de 60 diferentes compostos orgânicos presentes nos sedimentos, sendo a maioria proveniente de atividades agrícolas como espalhantes, espessantes e herbicidas, seguido de compostos provenientes de atividades de origem animal como os esteróides.

Dores \& Freire (2001) fizeram um levantamento dos agrotóxicos mais utilizados em Primavera do Leste no Mato Grosso, caracterização do solo e levantamento das condições climáticas da região e por meio destas informações realizou uma análise preliminar da contaminação por agrotóxicos no ambiente aquático.

Um dos poucos programas estaduais de monitoramento da qualidade da água no Brasil é realizado nas Bacias hidrográficas do estado de São Paulo pela CETESB, que avalia a qualidade das águas interiores desde 1974. Iniciou o estudo com 47 pontos de coleta e atualmente conta com 154 pontos de monitoramento. A partir de 1990, um programa de monitoramento de águas subterrâneas, avaliando 76 poços profundos e em 2003, iniciou o monitoramento de sedimentos em 18 pontos. Apesar da CETESB possuir um sistema de monitoramento bem estruturado, este não contempla os principais agrotóxicos (ou seus princípios ativos) comercializados no país, atendendo geralmente aos organoclorados.

Dados recentes do programa de monitoramento (CETESB, 2003) sobre a qualidade dos corpos d'água do estado, com vistas ao abastecimento público, apresentaram um predomínio das classes Bom a Regular sobre as demais classes, porém, as classes Ruim e Péssima, totalizaram $32 \%$ do total dos pontos monitorados. A qualidade das águas subterrâneas apresentou qualidade boa ou aceitável para abastecimento, com casos pontuais que ultrapassam os padrões de potabilidade. 
Recentemente, foram otimizadas três metodologias distintas em nossos laboratórios: a primeira por Lebre (2000) para a determinação de herbicidas (atrazina, simazina e trifluralina) e inseticidas (aldicarb, carbaril e carbofuran) em águas superficiais utilizando extração líquido-sólido e cromatografia líquida de alta eficiência, a qual foi utilizada neste trabalho. Katsuóka (2001) desenvolveu um método para determinação de agrotóxicos organoclorados em água e sedimento por cromatografia gasosa acoplada à espectrometria de massas (CG-MS). E por último Komatsu (2004) desenvolveu determinação de trifluralina, simazina, atrazina, pentaclorofenol, bifentrina, permetrina em águas empregando microextração em fase sólida (SPME) e cromatografia gasosa (CG-MS).

\subsection{Agrotóxicos e sua aplicação na agricultura.}

Na Antiguidade Clássica os povos gregos e romanos usavam arsênio para o controle de insetos, na China há cerca de 2000 anos obtinham-se inseticidas naturais à base de piretrina extraída das flores de crisântemos (Chrysanthemum sp). Os povos do deserto protegiam suas tendas de armazenamento de cereais acrescentando pó de piretro sobre os grãos ou pendurando feixes dessas flores na entrada das tendas. Outros compostos vegetais, como a nicotina e a rotenona (extraída de raízes do timbó), eram há muito tempo conhecidos por suas propriedades inseticidas.

No século XIX na Europa, o controle de pragas e doenças nas plantações e pecuária era feito utilizando extratos vegetais e compostos inorgânicos. Entre o final deste século e nas três primeiras décadas do século $X X$ houve um avanço mundial no uso de produtos químicos para a proteção de plantas contra pragas e doenças. Estes produtos eram constituídos basicamente por compostos inorgânicos à base de flúor, arsênico, mercúrio, selênio, chumbo, bórax, sais de cobre e zinco. Como exemplo podemos citar o verde-paris (acetoarsenito de cobre) e calda bordalesa (sulfato de cobre) (Guerra \& Sampaio, 1991; Alves Filho, 2000). 
A grande transição na metodologia de controle das pragas deu-se a partir da utilização do DDT (Dicloro Difenil Tricloetano), sintetizado pela primeira vez por Othmar Zeidler em 1873, mas que somente em 1939 suas propriedades inseticidas foram descobertas por Paul Müller. A importância de sua descoberta pode ser evidenciada pelo Prêmio Nobel que recebeu em 1948. No mesmo período, a partir da segunda Guerra Mundial, houve um incremento na síntese de substâncias orgânicas com propriedades biocidas. Na Alemanha, Scharade faz a síntese do organosfosforado quando tentava produzir gases tóxicos para uso na guerra. A indústria química americana trabalhou intensamente no desenvolvimento de substâncias que pudessem ser aplicadas na destruição, por via aérea, das áreas de colheitas dos inimigos (Larini, 1999; Alves Filho, 2000; SMA, 1992; Baird, 2002).

A partir da segunda metade do século $X X$ a comunidade técnica internacional começa a reavaliar a segurança e eficácia dos agrotóxicos. Esse processo é intensificado com as denuncias feitas por Rachel Carson em seu livro Silent Spring (Primavera Silenciosa), no ano de 1962. A autora levanta os problemas de persistência e os danos ambientais causados pelo uso de agrotóxico e questiona os riscos e benefícios desse, principalmente o DDT. Mas, somente a partir de 1971 vários produtos sintéticos são banidos ou mantidos sob uso restrito por conta da constatação dos efeitos nocivos à saúde e ao ambiente, pela agência ambiental americana (Environmental Protection Agency - EPA).

O DDT foi o primeiro agrotóxico sintético utilizado na agricultura brasileira em 1943. Segundo Lima (1960), in Alves Filho, 2000, durante os anos de 1954 a 1960, foi intenso o processo de registro de novos produtos junto ao ministério da agricultura. Os números divulgados pelo serviço de defesa sanitária vegetal davam conta de que 2.045 produtos haviam sido registrados no período. Os agrotóxicos a base de organoclorados foram proibidos no Brasil, somente em 1985 através da Portaria $n^{0} \mathbf{3 2 9}$ do Ministério da Agricultura.

A utilização de agrotóxicos na produção agrícola dentro de um manejo adequado pode aumentar a produção em até $40 \%$, mas o uso indiscriminado 
destes produtos pode acarretar prejuízos ambientais, muitas vezes irreparáveis, e trazer sérias conseqüências à saúde humana.

Segundo a FAO os impactos toxicológicos dos agrotóxicos na saúde humana e nos seres vivos em geral dependem dos seguintes fatores (FAO, 1996; Beitz et al, 1994):

- Do tempo de exposição;

- Da quantidade aplicada;

- Da toxicidade, que é expressa como $\mathrm{LD}_{50}$ (concentração de agrotóxicos que mata metade dos organismos testes em um determinado período de tempo), resposta aguda (morte) ou crônica (não causa a morte, mas observa-se efeitos sub letais nos organismos testes como câncer, tumores, efeitos teratogênicos, efeitos na reprodução, etc).

- Da persistência, medida como tempo de meia-vida (tempo necessário para que a concentração do composto diminua 50\%). Determinada a partir de processos de degradação como hidrólise, biodegradação, oxidação e fotólise;

- Dos produtos de degradação, que podem ter toxicidade igual, maior ou menor que o produto principal, como exemplo o DDT que se degrada a DDE e DDD;

- Do comportamento do agrotóxico no ambiente, que depende da solubilidade, do coeficiente de partição octanol-água e do coeficiente de adsorção no solo.

Na FIG.7 é apresentado um esquema do movimento dos pesticidas após serem introduzidos no solo e na água (Hayes \& Laws, 1997). Um dos maiores problemas quanto ao uso dos agrotóxicos, que pode ser observado, é a 
contaminação do solo e da água, comprometendo todo o ecossistema, transportando diretamente os agrotóxicos para a cadeia alimentar via fenômeno físico-químico.

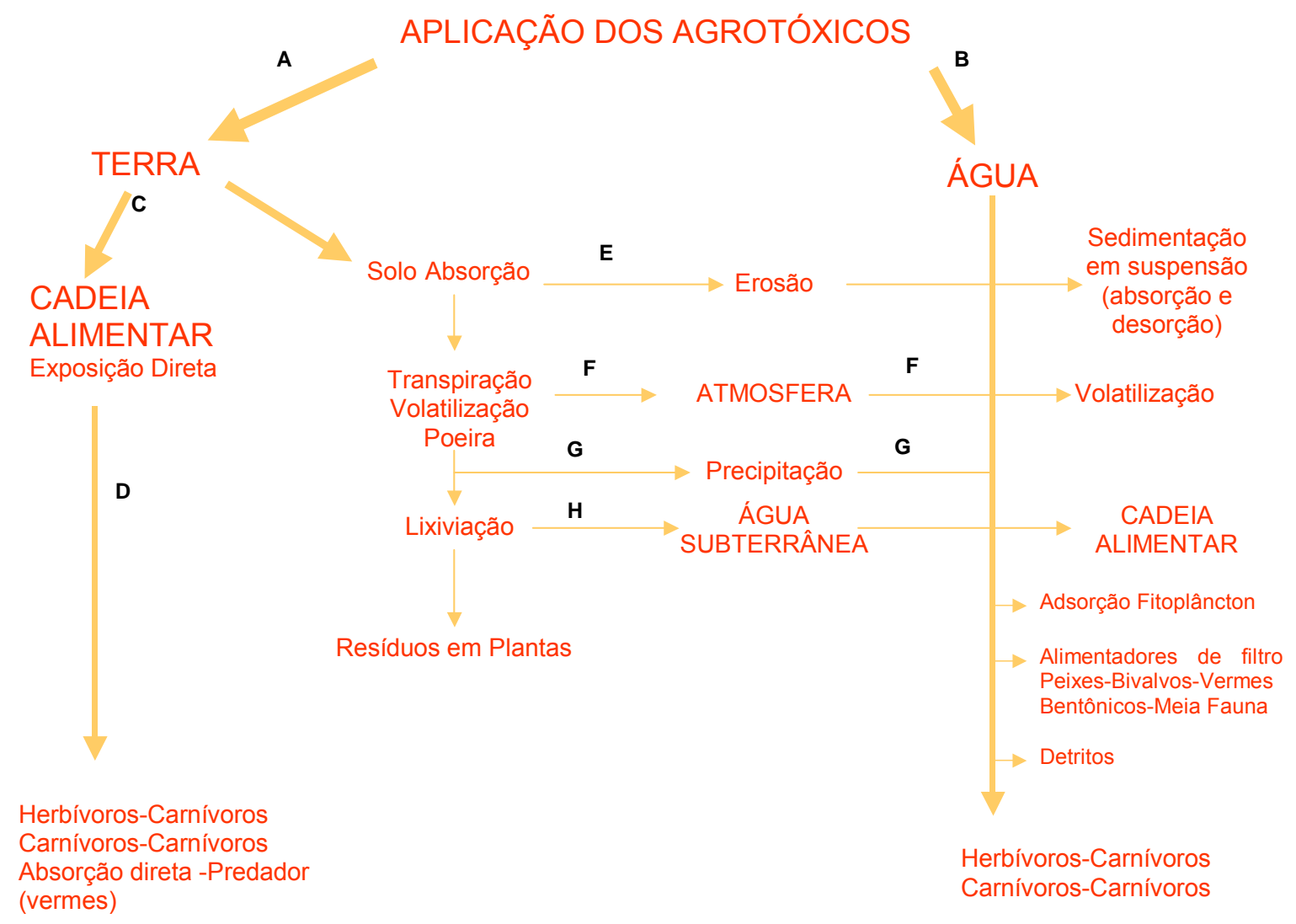

FIGURA 7 - Movimento dos agrotóxicos no meio ambiente por meio de caminhos abióticos e bióticos (Hayes \& Laws, 1997).

A movimentação segue os caminhos descridos a seguir: Os agrotóxicos são aplicados no solo (A) ou na água (B). Os agrotóxicos podem entrar na cadeia alimentar (D) via exposição direta ou através de uma fonte de alimento. Há movimentação dos mesmos no solo e na água pela erosão $(E)$, e ainda podem ser transportados para atmosfera via terra ou água (F). Os agrotóxicos podem contaminar novamente o solo e água através da precipitação $(G)$. A lixiviação do solo contamina as águas subterrâneas $(H)$ comprometendo a cadeia alimentar. 
Os agrotóxicos são classificados de acordo com o seu raio de ação como inseticidas, herbicidas, fungicidas, acaricidas, raticidas e outros. $E$ também segundo a sua estrutura química: benzoiluréicos, piretróides, organoclorados, carbamatos, bipirídínicos, uréicos, triazínicos, organofosforados, cimarínicos, nitroanilínicos, etc.

Do ponto de vista toxicológico eles são mais tóxicos ou menos ao homem, exigindo para cada composto um estudo de avaliação toxicológica correspondente. A toxidade é a propriedade dos agentes tóxicos de promoverem efeitos nocivos as estruturas biológicas, através de interações físico-químicas. A Organização Mundial da Saúde (OMS) classifica os agrotóxicos dividindo-os em cinco classes de acordo com os níveis de intoxicação, quando administrados geralmente em ratos albinos por via oral avaliando a $\mathrm{DL}_{50}$ (concentração nominal que mata $50 \%$ dos organismos expostos), mas pode ser também por via dérmica ou inalatória (OMS, 1995; Larini, 1999). Na TAB.4 é apresentado um resumo dos critérios para esta classificação.

TABELA 4 - Classificação toxicológica dos agrotóxicos (Larini, 1999)

\begin{tabular}{|c|c|c|c|c|c|}
\hline \multirow{2}{*}{ Classes } & \multicolumn{2}{|c|}{$\mathrm{DL}_{50}$ (via oral) $\left(\mathrm{mgkg}^{-1}\right)$} & \multicolumn{2}{|c|}{$\mathrm{DL}_{50}$ (via démica) $\left(\mathrm{mgkg}^{-1}\right)$} & \multirow{2}{*}{$\begin{array}{c}C L_{50} \\
\text { (inalatória) } \\
\left({ }^{*}\right)\end{array}$} \\
\hline & Sólido & Líquido & Sólido & Líquido & \\
\hline $\begin{array}{c}\text { l "a" - } \\
\text { Extremamente } \\
\text { tóxicos }\end{array}$ & \multicolumn{4}{|c|}{$\begin{array}{l}\text { Todos os produtos cuja } \mathrm{DL}_{50} \text { do constituinte ativo for igual ou } \\
\text { inferior a } 25 \mathrm{mgkg}^{-1} \text { (via oral) ou } 100 \mathrm{mgkg}^{-1} \text { (via dérmica) }\end{array}$} & \multirow{2}{*}{$\leq 0,2$} \\
\hline $\begin{array}{c}\text { l "b" - } \\
\text { Extremamente } \\
\text { tóxicos }\end{array}$ & $\leq 100$ & $\leq 200$ & $\leq 200$ & $\leq 400$ & \\
\hline $\begin{array}{l}\text { II - Altamente } \\
\text { tóxicos }\end{array}$ & $100<x \leq 500$ & $200<x \leq 2000$ & $200<x \leq 1000$ & $400<x \leq 4000$ & $0,2<x \leq 2,0$ \\
\hline $\begin{array}{c}\mathrm{III}- \\
\text { Medianamente } \\
\text { tóxico }\end{array}$ & $500<x \leq 2000$ & $\begin{array}{l}2000<x \\
\leq 6000\end{array}$ & $\begin{array}{l}1000<x \\
\leq 4000\end{array}$ & $\begin{array}{l}4000<x \\
\leq 12000\end{array}$ & $\begin{array}{l}2,0<x \\
\leq 20,0\end{array}$ \\
\hline IV - Pouco tóxico & $>2000$ & $>6000$ & $>4000$ & $>12000$ & $>20,0$ \\
\hline
\end{tabular}

$\left(^{*}\right)$ Expressa em $\mathrm{mgL}^{-1}$ de ar por 1 hora de exposição. 


\subsection{Principais características dos agrotóxicos avaliados}

Os compostos avaliados neste trabalho foram: aldicarbe, carbofurano e carbaril do grupo dos carbamatos; a simazina e atrazina do grupo das triazinas; e a trifluralina do grupo das nitroanilinas.

$\mathrm{Na}$ escolha dos agrotóxicos estudados levaram-se em conta os seguintes fatores: sua grande utilização tanto em escala mundial como em escala nacional, sendo alguns de uso regional. Estes compostos também foram avaliados e detectados, em amostras de água superficial e água tratada, em vários estudos de monitoramento consultados na literatura (Barceló, 1993; Biziuk et al, 1996; Dean et al, 1996; René van der Hoff et al, 1999; Azevedo et al, 2000; Katsuóka et al, 2000; Katsuóka, 2001; Stackelberg et al, 2001; Quintana et al, 2001; Hernández et al, 2001; Marques et al, 2003). Vale salientar que o carbofurano e o carbaril estão entre os agrotóxicos mais empregados na área de estudo e a simazina, a atrazina e trifluralina foram inclusos, recentemente, como parâmetro de potabilidade.

Os carbamatos são ésteres que possuem como estrutura comum: R-O$\mathrm{C}(\mathrm{O})-\mathrm{N}-\left(\mathrm{CH}_{3}\right)-\mathrm{R}^{\prime}$ ou R-S-C(O)-N-( $\left.\mathrm{CH}_{3}\right)-\mathrm{R}^{\prime}$, onde $\mathrm{R}$ é um álcool, oxinima, ou fenol e R` hidrogênio ou grupo metila (ex: aldicarbe, carbaril, carbofurano, metomil, oxamil). Estes compostos inibem a acetilcolinesterase em insetos e mamíferos, que absorvem via dérmica ou oral, não se acumulam no organismo e são eliminados para o ambiente (persistência moderada de 1 a 18 meses). Existem outros carbamatos que não inibem a acetilcolinesterase em grau significativo, sendo utilizados como herbicidas e fungicidas (Hayes \& Laws, 1997).

A trifluralina é do grupo dos dinitrobenzenamínicos, de uso bastante difundido e de aplicação em diversas culturas anuais ou perenes. Os herbicidas deste grupo químico são praticamente insolúveis na água e solúveis na maioria dos compostos orgânicos e têm uma persistência moderada no solo. Apresentam baixa toxidade aos mamíferos, pois são pouco absorvidos pela via oral e dérmica, atuando na divisão celular (Larini, 1999). 
As triazinas estão entre os herbicidas mais usados na agricultura em todo o mundo. Eles são aplicados em plantações em crescimento, bem como diretamente no solo. Apresentam alta toxicidade ao fitoplâncton ocorrendo decréscimo na taxa de fotossíntese, atingindo populações de peixes e crustáceos, por intermédio da cadeia alimentar. Estas substâncias são degradadas por processos químicos ou biológicos tendo baixa toxicidade a mamíferos. Sua estrutura é composta de três nitrogênios e três carbonos arranjados sistematicamente no anel aromático, ocorrendo as substituições nas posições 2 (mais comum cloro, metoxil, metilitiol), 4 e 6 (grupo amino). Atrazina, cianazina, propazina e simazina são os compostos mais utilizados (Hayes\& Laws, 1997; Lebre, 2000).

No APÊNDICE B são apresentadas as características, aplicação na agricultura nacional e classificação toxicológica dos pesticidas estudados neste trabalho, obtidos na literatura consultada (Tomlin, 1994; Compêndio de defensivos agrícolas,1996; Hayes \& Laws, 1997; Rodrigues \& Almeida, 1998; Larini, 1999; Toxnet, 2004; Anvisa, 2004;).

\subsection{Métodos para determinação de agrotóxicos}

A larga utilização de agrotóxicos nos países desenvolvidos como, por exemplo, Estados Unidos e os da Comunidade Comum Européia e em desenvolvimento como o Brasil, Chile, México e Índia, vêm provocando a contaminação dos escassos recursos hídricos disponíveis. Este fato tem mobilizado a comunidade científica a fim de se disciplinar o uso de agrotóxicos e estudar suas conseqüências no meio ambiente, bem como desenvolver métodos de determinação e detecção mais sensíveis e precisos (Barceló, 1993; Koh et al, 1996 ; Ecobichon, 2001).

A FAO recomenda a todos os países desenvolver um protocolo obrigatório para a proteção da saúde e meio ambiente, submetendo as fábricas de agrotóxicos a descreverem a ação e formulação do ingrediente ativo, caracterização toxicológica, propriedades toxicológicas, comportamento químico e destino no meio ambiente, métodos analíticos para detectar a ação do ingrediente 
e seus subprodutos, além de fornecer metodologias para a detecção de agrotóxicos espalhados na plantação e no meio ambiente através de análises de resíduos em águas subterrâneas e superficiais (Beitz et al, 1994; Katsuóka, 2001).

Normalmente os métodos empregados para a determinação de deste compostos são realizados em duas etapas: a extração e pré-concentração e a quantificação.

Dentre as técnicas de extração normalmente utilizadas como etapas de pré-concentração e "clean-up" (limpeza), destacam-se a extração líquido-líquido (LLE - Líquid Líquid Extraction), a extração em fase sólida (SPE - Solid Phase Extration), a extração com fluido supercrítico (SFE - Supercritical Fluid Extraction) e, mais recentemente, a micro extração em fase sólida (SPME - solid-phase microextraction).

As técnicas analíticas instrumentais mais empregadas são: a cromatografia gasosa (CG) com detecções: por captura eletrônica (ECD electron capture detector), nitrogênio - fósforo (NPD - nitrogen phosporus detector), fotométrico de chama (FPD - flame photometric detector), espectrometria de massas (MS - mass espectrometer) e cromatografia líquida de alta eficiência (LC) acoplada a detectores ultravioleta/visível (UV/vis), fluorescência ( $F L)$, espectrometria de massas (MS) e espectrometria de massas em Tandem (MS/MS). A combinação destas etapas possibilita o desenvolvimento de métodos analíticos multi-residuais mais sensíveis e seletivos para amostras de alimentos e ambientais (Pereira et al, 1990; Barceló, 1993; Barceló, 1993a; Sherma, 1995; Dogheim et al, 1996; Gascón et al, 1996; Sancho et al, 1996; Thomas et al, 1999; Schenck \& Lehotay, 2000; Ying \& Williams, 2000; Bruzzoniti et al, 2000; Tadeo et al, 2000; Barrionuevo \& Lanças, 2001; Stalikas \& Konidari, 2001; Neuhaus et al, 2002; Ohlenbusch et al, 2002; Goodiwin et al, 2003; Komatsu, 2004).

Os métodos propostos pela EPA-NPS (Environmental Protection Agency - National Pesticide Survey) utilizam tanto a técnica de cromatografia gasosa quanto a líquida, alguns empregam a extração em fase sólida em 
substituição à extração líquido-líquido. A SCA (United Standing Committee of Analysts) aplica métodos utilizando a técnica de CG, com exceção na determinação de carbamatos e triazinas; todos os métodos utilizam a extração líquido-líquido (Barceló, 1993). Em alguns casos é difícil fazer uma escolha entre as técnicas de cromatografia gasosa ou líquida para análise dos compostos. Em geral, o método preferido é o que oferecer menor manipulação da amostra, boa sensibilidade, baixo custo e rapidez (Lebre, 2000; Katsuóka, 2001). 


\section{4 ÁREA DE ESTUDO}

\subsection{Características Gerais da Bacia Hidrográfica do Ribeira de Iguape}

A Bacia hidrográfica do Ribeira de Iguape, demoninada também de Vale do Ribeira e Unidade de Gerenciamento de Recursos Hídricos 11, Vale do Ribeira e Litoral Sul (UGRHI - 11), está localizada na região sul do estado de São Paulo e leste do Estado do Paraná, entre as latitudes $23^{\circ} 50^{\prime}$ e $25^{\circ} 30^{\prime}$ ao Sul do Equador e longitudes $46^{\circ} 50^{\prime}$ e $50^{\circ} 00^{\prime}$ ao Oeste de Greenwich. Abrange uma área de aproximadamente $25.000 \mathrm{~km}^{2}$, dos quais cerca de $17.000 \mathrm{~km}^{2}$ (dois terços) estão no território paulista (CETESB, 2003). No critério de escolha da área piloto foi observado locais com pouca ou nenhuma atividada antrópica com área de proteção ambiental e estação ecológica.

Compreende as Bacias dos rios Juquiá, Ribeira e Ribeira de Iguape, além dos rios que deságuam no mar, e canais estuarinos, como é o caso dos Rios Comprido ou Una, Rio Itimirim, Rio Iririaia-Mirim e Rio Ipiranguinha. Suas nascentes, em geral, encontram-se na vertente marítima da serra do Mar e, após vencerem desníveis acentuados, conformam planícies flúvio-marinhas, drenam manguezais e deságuam no oceano ou canais estuarinos, desde o município de Iguape até a divisa com o estado do Paraná. Limita-se a sudoeste com o Estado do Paraná, ao norte com as UGRHIs 14, do Alto Paranapanema, e 10, do Sorocaba e Médio Tietê, a nordeste com as UGRHIs 6, do Alto Tietê, e 7, da Baixada Santista, e a leste com o Oceano Atlântico. Na FIG.8 é apresentada a localização da UGRHI no Estado de São Paulo (CETEC, 2000).

Com uma área de drenagem de $16.607 \mathrm{~km}^{2}$, abrange 23 municípios, com uma população total de 358.565 habitantes, sendo 234.124 na zona urbana. As maiores cidades são: Registro, Cajatí, Iguape e Apiaí (CETESB, 2003; CETEC, 2000). Esta Bacia compõem a região dos estados de São Paulo e Paraná mais privilegiados pelas belezas que a natureza pode oferecer. O relêvo extremamente movimentado na maior parte da área enseja o encachoeiramento de seus rios que descem velozmente as encostas das serras. Isso ocorre principalmente com os afluentes da margem esquerda do Rio Ribeira, até a 
proximidade de Sete Barras, e do Rio Juquiá, seu maior contribuinte, que tem suas nascentes em altitudes de cerca de $700 \mathrm{~m}$. Recebendo também contribuição de cursos d’água com nascentes a mais de $1.000 \mathrm{~m}$, desaguando em altitudes menores que $200 \mathrm{~m}$ num desnível, em poucos quilômetros, de mais de $700 \mathrm{~m}$ (Ureniuk, 1989).

A alta pluviosidade da região propicia o desenvolvimento de vegetação, de grande exuberância, cobrindo a paisagem de verde mesmo nas áreas recentemente devastadas pela ação antrópica. Nesta encontram-se a Área de Proteção Ambiental da Serra do Mar, os Parques Estaduais do Alto Ribeira e Jacupiranga, as Áreas de Proteção Ambiental de Cananéia-Iguape-Peruíbe e da Ilha Comprida e a Estação Ecológica da Juréia.

A região possui a maior concentração da Mata Atlântica do país. Este bioma, hoje reduzido a menos de $5 \%$ da sua área original, possui uma biodiversidade tão rica quanto à da Floresta Amazônica é atualmente objeto de campanhas de preservação, entre elas o Programa "Homem e a Biosfera - MAB" da UNESCO. A área de floresta natural do estado de São Paulo também está concentrada na região, como se pode observar na FIG.9 (Hogan et al, 2001; C.A.T.I., 2004). 

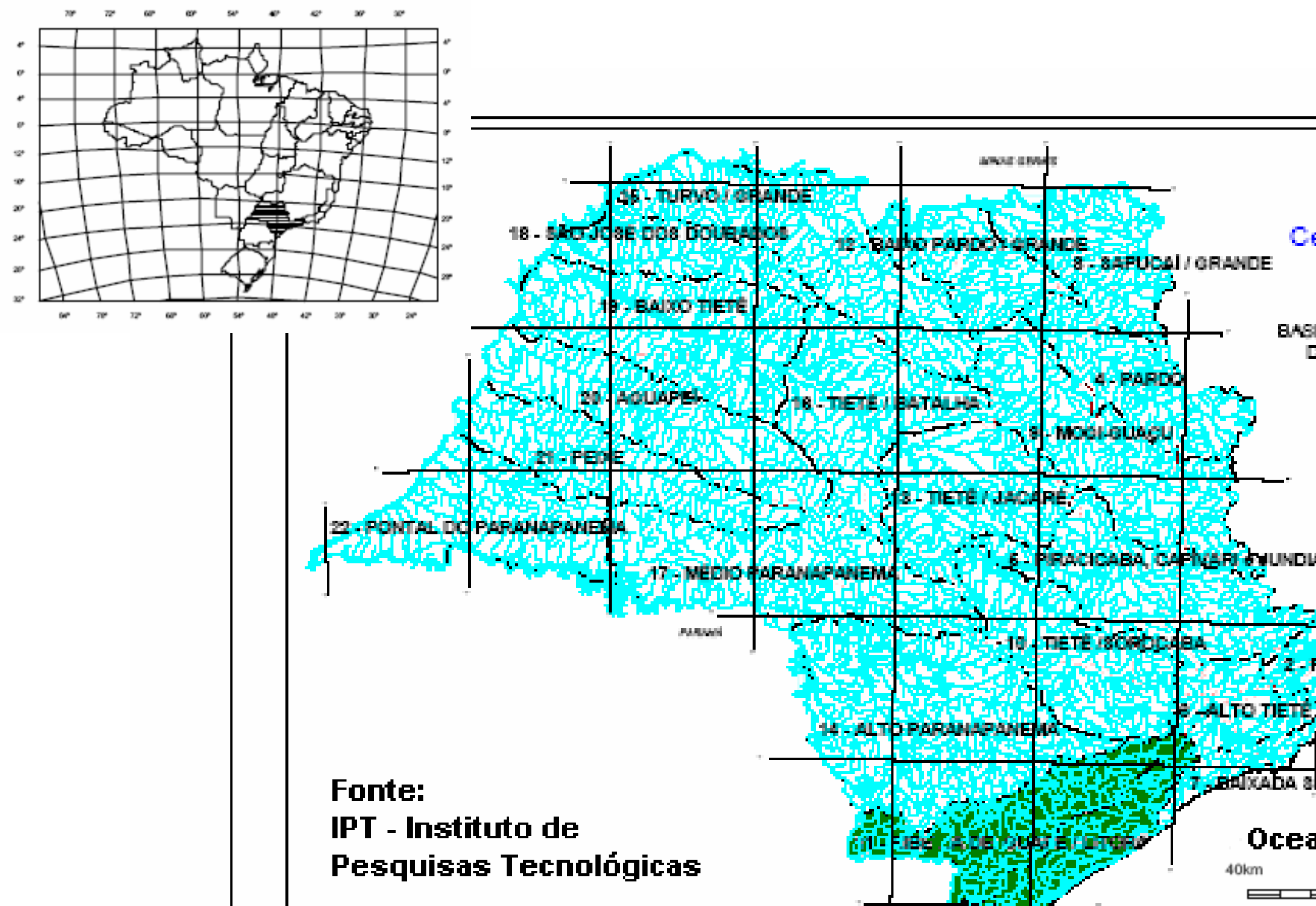

DE DADOS GEQAMIEIENTNS DO ESTADO DE SROO PAULO

\section{CETEC}

Centro Tecnológico

Lins - SP

PT - Instituto de

Pesquisas Tecnológicas

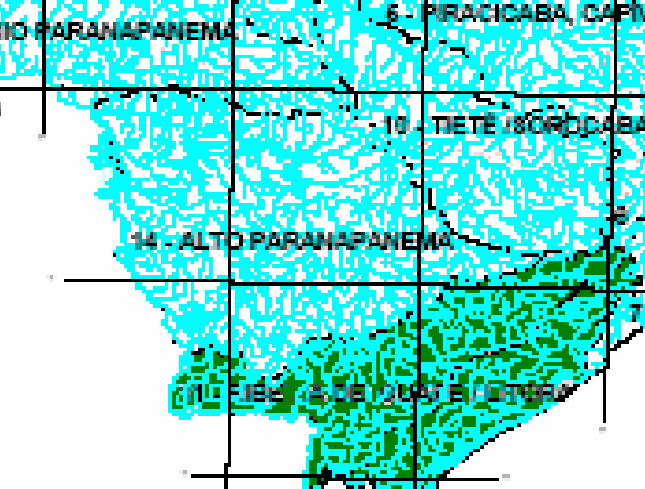

11 - RIBEIRA DE IGUAPE I LITORAL

\section{Oceano Atlântico}

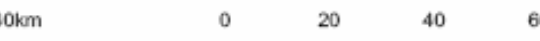

$60 \quad 80 \mathrm{~km}$

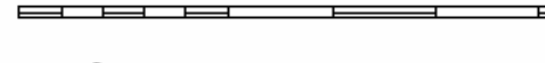

1998

FIGURA 8 - Localização da Bacia Hidrográfica do Ribeira de Iguape, no Estado de São Paulo. 


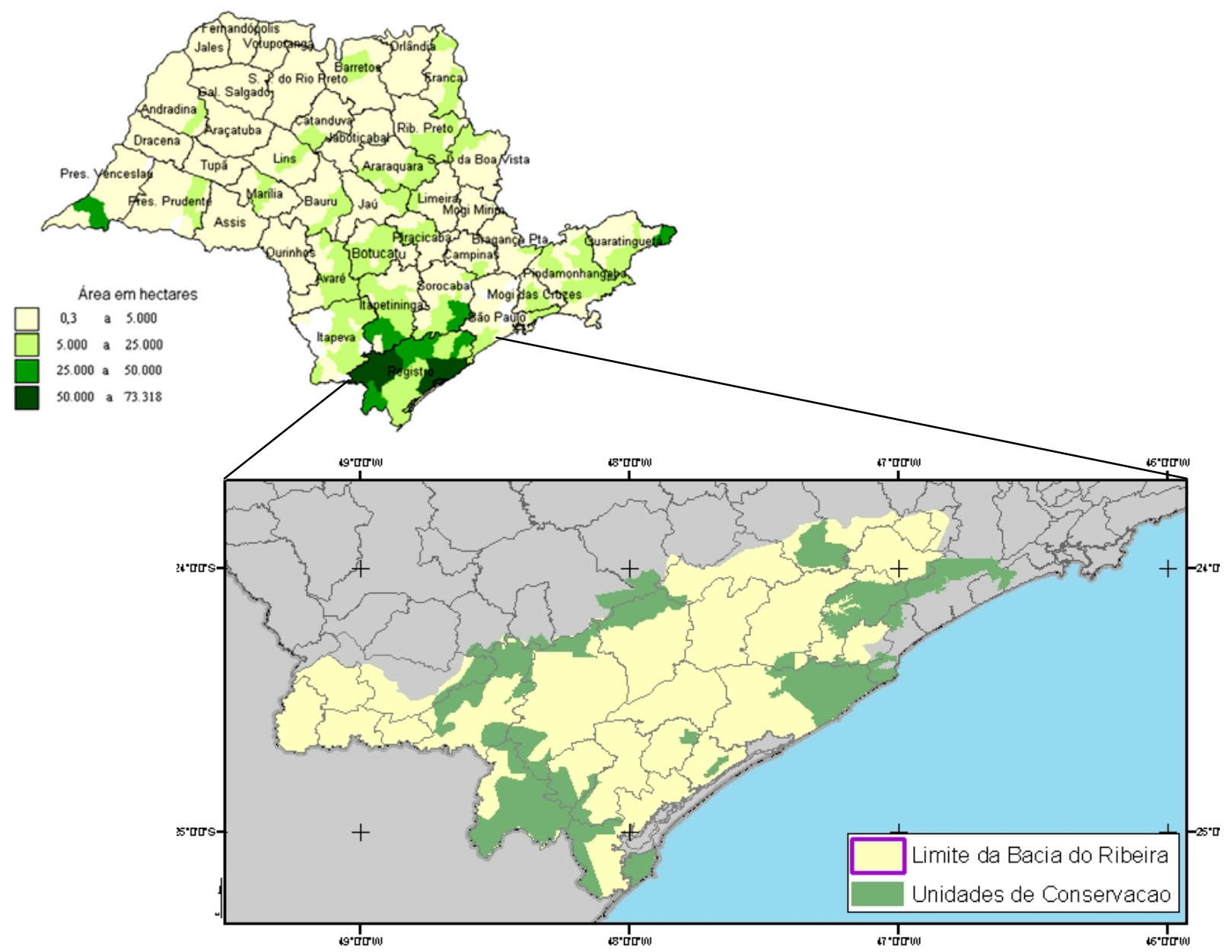

FIGURA 9 - Distribuição da área ocupada por floresta tropical natural no estado de São Paulo (CATI - LUPA, 2004) e distribuição por Unidade de Conservação, na Bacia Hidrográfica do Ribeira de Iguape, SP.

Muitas unidades possuem superposição legal e espacial de áreas ou têm fronteiras entre si, além de apresentarem conflitos nos seus conceitos e objetivos. Embora, de uma forma genérica, cada categoria de área protegida possui diferentes objetivos de gestão, expressos nos termos de sua respectiva legislação (mesmo que não é admissível definir objetivos únicos), a União Internacional para a Conservação da Natureza (UICN), em encontros internacionais definiu categorias de Unidades de Conservação Ambiental, baseadas em critérios de gestão e manejo - desde a preservação restrita ao uso sustentado (CETEC, 2000). A correspondência dos objetivos de gestão classificados internacionalmente e os mesmos objetivos de algumas áreas protegidas pela legislação brasileira constam da TAB. 5 . 
Tabela 5 - Correspondência entre áreas protegidas por lei da UGRHI 11 e as categorias classificadas pela União Internacional para a Conservação da Natureza UICN (CETEC, 2000).

\begin{tabular}{|c|c|}
\hline $\begin{array}{c}\text { Objetivos da gestão } \\
\text { (objetivo principal do manejo). }\end{array}$ & Áreas protegidas da Bacia \\
\hline I - Proteção restrita & $\begin{array}{l}\text { Reserva Natural Estrita e Área Natural } \\
\text { silvestre Estação Ecológica de Chauás, } \\
\text { Estação Ecológica tupiniquins, Estação } \\
\text { Ecológica Juréia - Itatins. }\end{array}$ \\
\hline $\begin{array}{c}\text { II - Conservação de ecossistemas e } \\
\text { turismo/recreação }\end{array}$ & $\begin{array}{l}\text { Parque Estadual da Serra do Mar, } \\
\text { Parque Estadual Carlos Botelho, Parques } \\
\text { Estadual Jacupiranga, Parque Estadual } \\
\text { da Ilha do Cardoso, Parques Estadual } \\
\text { Campina do Encantado e Parque } \\
\text { Estadual Jurupará. }\end{array}$ \\
\hline $\begin{array}{l}\text { III - Conservação das } \\
\text { características naturais }\end{array}$ & $\begin{array}{l}\text { Área de Relevante Interesse Ecológico } \\
\text { (ARIE) ZVS }{ }^{1} \text { da llha Comprida. }\end{array}$ \\
\hline \multicolumn{2}{|l|}{$\begin{array}{c}\text { IV - Conservação através da gestão } \\
\text { ativa }\end{array}$} \\
\hline $\begin{array}{c}\text { V - Conservação de paisagens } \\
\text { terrestres marinhas e lazer / } \\
\text { recreação }\end{array}$ & $\begin{array}{l}\text { APA Cananéia - Iguape - Peruíbe, APA } \\
\text { Serra do Mar e APA Ilha Comprida, Área } \\
\text { Sob Proteção Especial (ASPE) da Juréia. }\end{array}$ \\
\hline $\begin{array}{c}\text { VI - Uso sustentável / sustentável } \\
\text { de ambiente / ecossistemas } \\
\text { naturais. }\end{array}$ & $\begin{array}{l}\text { Tombamento da Serra do Mar e } \\
\text { Paranapiacaba, Tombamento de Ilhas do } \\
\text { litoral paulista, Áreas Indígenas. }\end{array}$ \\
\hline
\end{tabular}

1 - Zona de Vida Silvestre

\subsection{Caracterização geomorfológica}

A caracterização morfológica da região, descrita a seguir, foi realizada mediante informações obtidas no mapa geomorfológico do Estado de São Paulo (IPT, 1997).

A área de drenagem da Bacia do Rio Ribeira de Iguape apresenta macrocompartimentos morfoestruturais do Cinturão Orogênico do Atlântico e Bacias Sedimentares Cenozóicas/Depresões Tectônicas. Esses 
macrocompartimentos são divididos em diferentes níveis morfológicos e a região compreende: o Planalto do Ribeira Turvo ao Sul, Planalto de Ibiúna/São Roque no limite Setentrional, Escarpa/Serra do Mar e Morros Litorâneos a Nordeste da região, a Depressão do Baixo Ribeira na central com pequenas planícies aluviais ao longo dessa e a Planície Litorânea Iguape/Cananéia.

Os Planaltos e Depressões apresentam relevos de denudação e as planícies de agradação.

O Planalto do Ribeira/Turvo apresenta como forma de relevo dominante morros altos com topos agudos e convexos com:

- Altimetria dominante entre 700 e $900 \mathrm{~m}$ de declividade alta $(20$ a $30 \%)$;

- A Litologia dominante é composta por granitos, Migmáticos e Micaxisto;

- Os tipos de solos dominantes são: Cambrissolos, Litólicos e Afloramentos rochosos.

Esta região da Bacia apresenta áreas com níveis de fragilidade que variam de potencial baixo a muito alto, com formas muito dissecadas com vales entalhados associados a vales pouco entalhados, com alta densidade de drenagem. Essas são sujeitas a processos erosivos e agressivos com probabilidade de ocorrência de movimentos de massa e erosão linear com voçorocas.

O Planalto Ibiúna/São Roque apresenta como forma de relevo dominante morros altos com topos agudos e convexos com:

- Dois grupos de altimetria dominantes: entre 900 e $1.000 \mathrm{~m}$ de declividade muito alta ( $>30 \%$ ) e 800 a $900 \mathrm{~m}$ com declividade alta (20 a $30 \%)$; 
- A litologia dominante é composta por Granitos, Gnaisses e Migmáticos;

- Os tipos de solos dominantes são: Podzólico Vermelho - Amarelo e Latossolo Vermelho - Amarelo.

Esta região da Bacia também apresenta áreas com níveis de fragilidade que variam potencial médio a alto, com formas de dissecação de média a alta, com vales entalhados e densidade de drenagem que varia de média a alta. Essas são sujeitas fortes atividades erosivas.

A Escarpa/Serra do Mar e Morros Litorâneos apresentam modelos dominantes de Escarpas e Cristas e também de formas agudas e convexas com:

- Duas variações altimétricas: de 10 a 1.000m com declividade muito alta (>30\%) e 10 a 200m com declividade alta (20 a $30 \%$ );

- A litologia dominante apresenta Granitos, Migmatitos, Gnaisses e Micaxisto.

- Nesta região os solos dominantes são: Cambrissolos, Litólicos e Afloramento rochoso.

Esta região apresenta fragilidade que varia de alta, próximo ao Vale do Ribeira, a muito alta, próximo à região litorânea, com formas de dissecação muito intensa e vales de entalhamento pequeno e densidade de drenagem baixa. Essas áreas são sujeitas aos processos erosivos agressivos inclusive com movimentos de massa.

A Depressão do Baixo Ribeira possui um relevo formado por colinas baixas e pequenas de formas convexas e superfícies planas e vales de fundos planos, com:

- Altimetria variando de 0 a $30 \mathrm{~m}$ de baixa declividade (10 a $20 \%$ ); 
- A litologia dominante de Sedimento Argilo-Arenoso com lentes de conglomerados recobrindo total ou parcialmente Migmatitos e Migmatitos Xistosos;

- O solo dominante é o Podzólico Vermelho-Amarelo.

A área apresenta um nível de fragilidade potencial muito alto. A Bacia Hidrográfica do Rio Ribeira nessa região apresenta Planícies Fluviais as margens dos seus rios com as seguintes características:

- Modelos em formas de planícies e terraços fluviais com declividade $<2 \%$;

- Os solos são Glei Hêmico e Glei pouco Hêmico;

- Com litologia dominante de Sedimentos Arenosos e Argilosos Inconsolidados;

- E níveis de fragilidade potencial muito alto.

O litoral da região é formado pela Planície Litorânea o Iguape/Cananéia a qual apresenta formação predominante de Planície Marinha com áreas de Planície Fluvial e Intertidal (Mangue). A altimetria varia de 0 a $20 \mathrm{~m}$ com declividade $<2 \%$. A litologia dominante é de Sedimentos Marinhos e Fluviais Inconsolidados (areias, argilas e cascalhos). Os solos são Podzol Hidromórfico e Hidromórfico com níveis de fragilidade potencial muito alto.

Os níveis de fragilidade potenciais classificados como muito alto para as planícies apresentam as seguintes características: áreas sujeitas a inundação periódicas, lençol freático pouco profundo e sedimentos inconsolidados sujeitos a acomodações.

As informações geomorfológicas acima foram escritas baseada no mapa geomosfológico do Estado de São Paulo do IPT, 1997 apresentado na FIG.10. 


\subsection{Recursos hídricos e o sistema de saneamento básico}

O rio Ribeira nasce no Paraná e somente passa a ser denominado Ribeira de Iguape após a confluência com seu principal afluente o Juquiá. Segundo os parâmetros do CONAMA no 20/86, todos os corpos d’água dessa região foram enquadrados na Classe 2 (águas que podem ser destinadas ao abastecimento humano, após tratamento convencional). Com exceção dos rios Sete Barras, Turvo e seus afluentes, São João, Córrego dos Veados, Córrego Poço Grande, Rio João Surrá e seus afluentes que pertencem a Classe 1(águas que podem ser destinadas ao abastecimento para consumo humano, após tratamento simplificado), no Estado do Paraná, e no Estado de São Paulo, o Rio Juquiá e todos os seus afluentes até a divisa dos Municípios de Juquitiba e Miracatu exceto o Rio São Lourenço que se enquadra como rio de classe 2 (CETESB, 2003; CETEC, 2000).

Toda a bacia nos últimos anos vem recebendo a classificação Boa para suas médias anuais do Índice de Qualidade de Água (IQA) (CETESB, 2003). Embora, seja notória a degradação dos principais cursos d'água da UGRHI, em virtude de fortes lançamentos de esgotos sem tratamento e de atividades agrícolas.

De uma forma geral, têm sido observados concentrações acima dos valores máximos permissíveis de diversos parâmetros, em relação aos padrões estabelecidos para as classes dos corpos d'água da bacia. Em especial, as concentrações de fosfato total e coliformes fecais apresentam-se, persistentemente, fora dos padrões. Testes de toxicidade mostraram que 13\% das amostras encontram-se com toxidade crônica. Este fato evidenciou que a qualidade das águas para a vida aquática não é boa (CETEC, 2000) 


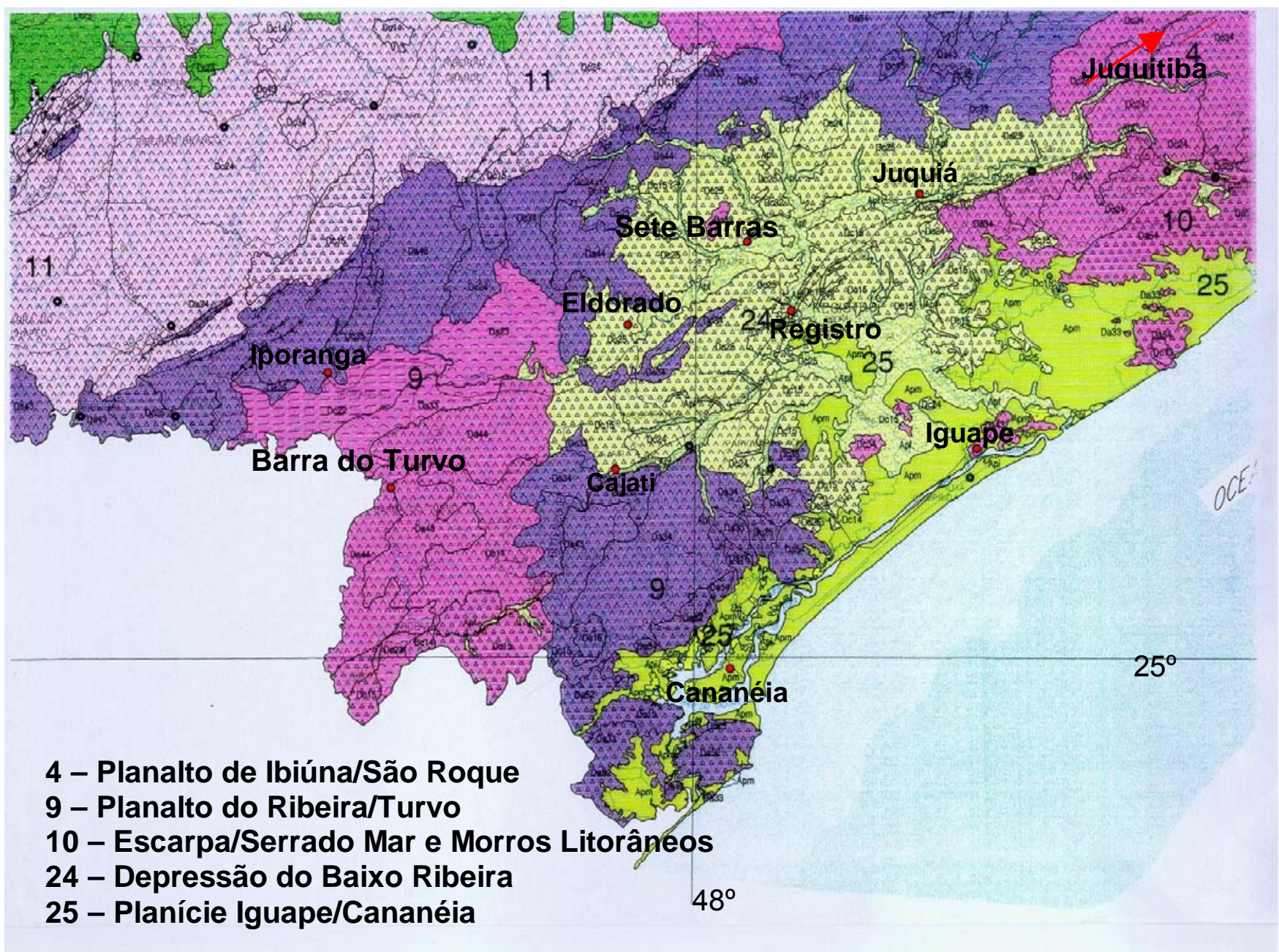

FIGURA 10 - Mapa Geomorfológico da Bacia do Rio Ribeira de Iguape Escala 1:500.000, Adaptado de IPT (1997). 
As condições da saúde pública no Vale do Ribeira são reflexos da baixa qualidade de vida de sua população, das relações de produção desfavoráveis, da fragilidade da base econômica e da precariedade das infraestruturas, apresentando deficiências nos sistemas públicos de esgoto, bem como carência de assistência médica e sanitária, principalmente nas áreas rurais (Setti et al, 2001). Têm-se verificado a expansão de endemias transmitidas por morcegos, doença de chagas, além da malária e da esquistossomose, comuns da região. Além disso, dados de mortalidade infantil e desnutrição são os maiores dos respectivos estados.

A Bacia do Ribeira de Iguape é a única no estado de São Paulo onde a relação disponibilidade versus demanda é extremamente positiva. Com uma situação privilegiada em relação a demais no tocante a qualidade e quantidade de água tanto por apresentar a mais elevada disponibilidade como pela demanda ainda pequena dos recursos hídricos superficiais e subterrâneos (DAEE, 2000). Portanto, é importante que se faça um planejamento avaliando-se a demanda atual e o potencial da bacia e ainda analisem-se as perspectivas de evolução. Procurando compatibilizar o desenvolvimento regional com a proteção dos recursos hídricos, escolhendo diretrizes de desenvolvimento adequadas à implantação na região de atividades que sejam compatíveis com a estrutura do solo e a preservação da sua cobertura vegetal na medida em que isto apresente maior ou menor importância.

Segundo o DAEE, a Bacia do Ribeira de Iguape tem uma demanda total de $6,08 \mathrm{~m}^{3} \mathrm{~s}^{-1}$ dividida em 1,$11 ; 2,67$ e 2,3 $\mathrm{m}^{3} \mathrm{~s}^{-1}$ para os usos: urbano, industrial e irrigação, respectivamente. A sua disponibilidade hídrica, na forma de $Q_{7,10}{ }^{1}$, atinge níveis $179,24 \mathrm{~m}^{3} \mathrm{~s}^{-1}$, portanto, a relação demanda/disponibilidade para toda a bacia é somente de 3,39\%. Na FIG.11 é apresentado o gráfico comparativo entre a disponibilidade da bacia hidrográfica e as demandas superficiais para o uso e abastecimento urbano, industrial e irrigação.

${ }^{1} \mathrm{Q}_{7,10}=$ vazão de 7 dias para 10 anos de retorno, em $\mathrm{m}^{3} \mathrm{~s}^{-1}$ 
De acordo com o cadastro do DAEE, o total de água captada para a indústria é de 2,672 $\mathrm{m}^{3} \mathrm{~s}^{-1}$, em que a Serrana Mineração e a Fazenda Vale do Eta captam 1,29 e $0,98 \mathrm{~m}^{3} \mathrm{~s}^{-1}$ dos rios Jacupiranguinha e Eta, respectivamente, sendo os maiores consumidores.

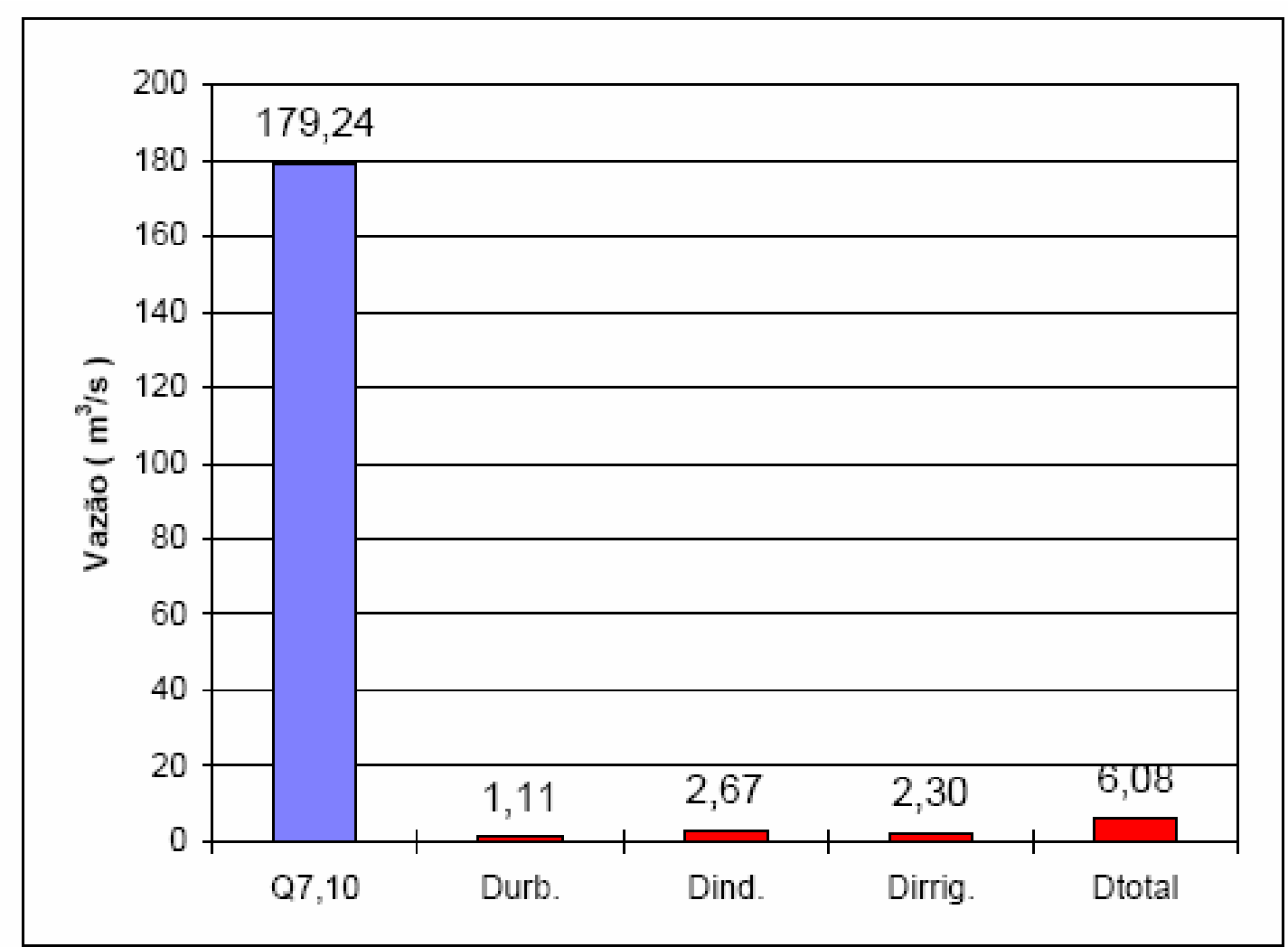

FIGURA 11 - Comparação disponibilidade $\left(Q_{7,10}\right) X$ demanda (D) para a Bacia Hidrográfica do Rio Ribeira de Iguape (CETEC, 2000).

OBS: Durb. = demanda urbana, Dind. = demanda industrial, Dirrig. = demanda para irrigação e Dtotal $=$ demanda total.

Na TAB.6 são apresentadas as demandas de água para irrigação distribuída entre as treze sub-bacias da UGRHI 11. As sub-bacias de Jacupiranga e Ribeira de Iguape respondem por $57 \%$ da irrigação dos histogramas de vazões, seguida das sub-bacias de São Lourenço e Baixa Ribeira com $24 \%$.

O Sistema de Saneamento do Vale do Ribeira, Litoral Sul, denominado pela SABESP de Unidade de Negócio Vale do Ribeira / Litoral, abastece 18 municípios e 48 comunidades isoladas. O sistema operacional das estações de tratamento de água (ETA's) da SABESP de Registro é pioneiro em automação, 
onde $100 \%$ das ETA's são automatizadas, integradas por um Centro de Controle Operacional, em Registro.

A captação da água superficial para o município de Registro é realizada no rio Ribeira de Iguape, a jusante da cidade, por meio de bombas submersíveis. À jusante da captação existem portos de areia e muita área agrícola. À montante da captação existe o lançamento dos efluentes das lagoas de tratamento de esgotos de Sete Barras, Eldorado e Jaguarí-Mirim.

TABELA 6 - Estimativa da demanda para irrigação nas sub-bacias (CETEC,2002).

\begin{tabular}{cccc}
\hline Sub-bacia & $\begin{array}{c}\text { Cultura } \\
\left(\mathbf{K m}^{2}\right)\end{array}$ & $\begin{array}{c}\text { Área irrigada } \\
\mathbf{( \% )}\end{array}$ & $\begin{array}{c}\text { Q irrigação } \\
\left(\mathbf{m}^{\mathbf{3}} \mathbf{s}^{-1}\right)\end{array}$ \\
\hline 1. Córrego Alto Ribeira & 0 & 0 & 0 \\
\hline 2. Baixo Ribeira & 57,2 & 11 & 0,248 \\
\hline $\begin{array}{c}\text { 3. Rio Ribeira de } \\
\text { lguape }\end{array}$ & 138 & 26 & 0,599 \\
\hline 4. Alto Juquiá & 0 & 0 & 0 \\
\hline 5. Médio Juquiá & 8,12 & 2 & 0,035 \\
\hline 6 baixo Juquiá & 24,3 & 5 & 0,298 \\
\hline 7. S. Lourenço & 68,7 & 13 & 0,045 \\
\hline 8 Itariri & 10,3 & 2 & 0,218 \\
\hline 9 . Una da aldeia & 50,3 & 9 & 0 \\
\hline 10. Pardo & 0 & 0 & 0,714 \\
\hline 11. Jacupiranga & 165 & 31 & 0,037 \\
\hline 12. Vert. Marítima Sul & 8,53 & 2 & 0 \\
\hline 13 Vert. Maritina Norte & 0 & 0 & \\
\hline
\end{tabular}

A cidade de Iporanga é abastecida pelo Rio Ribeirão de Iporanga que deságua também no Ribeira. A CETESB recentemente levantou problemas de contaminação por chumbo, devido à presença de minas desativadas no estado do Paraná, no município de Adrianópolis. Estudos recentes (Cotrim et al, 2004; Pires, 2004) sobre o monitoramento de metais, em especial do chumbo, na bacia do Ribeira de Iguape mostraram que as concentrações de chumbo monitoradas nos 
mananciais superficiais, variaram de 0,003 a $0,009 \mathrm{mgL}^{-1}$, e apresentaram valores aproximadamente duas vezes maiores que as concentrações observadas nas águas subterrâneas e nos mananciais de serra. Das 24 amostras de sedimentos analisadas, os sedimentos do Ribeira de Iguape coletados nas áreas de captação de água dos municípios de Eldorado e Sete Barras apresentaram altas concentrações de chumbo $\left(121,5\right.$ e $\left.102,3 \mu \mathrm{gg}^{-1}\right)$.

Segundo informações do Controle Sanitário da SABESP de Registro (dados de 2002), o Vale do Ribeira possui $560 \mathrm{~km}$ de rede de esgoto, com 34 estações de tratamento de esgoto (ETE), 103 estações elevatórias de esgoto (EEE), tendo 95\% de esgoto tratado. Na TAB.7 é apresentado o quadro evolutivo do setor de saneamento na região.

Tabela 7 - Evolução no atendimento do Sistema de Esgoto do Vale do Ribeira (dados fornecidos pela SABESP - Registro, 2002).

\begin{tabular}{ccc}
\hline Parâmetro / Evolução (ano) & $\mathbf{1 9 9 4}$ & $\mathbf{2 0 0 2}$ \\
\hline Número de ETE's & 08 & 34 \\
\hline Número de EEE's & 22 & 103 \\
\hline Coleta de esgoto (\%) & 37 & 60 \\
\hline Esgoto tratado (\%) & 20 & 60 \\
\hline Rede de esgoto $(\mathrm{Km})$ & 300 & 560 \\
\hline População & 307.487 & 358.565 \\
\hline
\end{tabular}




\section{PARTE EXPERIMENTAL}

O principal interesse deste trabalho está voltado para aprofundar o conhecimento científico quanto à qualidade de água e o uso de agrotóxicos na Bacia Hidrográfica do rio Ribeira de Iguape, litoral sul do estado de São Paulo e, de servir como base para realizar uma análise crítica da legislação que estabelece os parâmetros de potabilidade.

Para atingir os objetivos dividiu-se o estudo em etapas distintas:

- Realizar uma análise crítica da legislação que estabelece o controle de qualidade das águas destinadas ao consumo humano.

- Avaliar a área de estudo quanto ao uso e ocupação do solo definindo os principais indicadores a serem avaliados.

- Realizar uma análise do risco potencial de contaminação por agrotóxicos, em águas superficiais e subterrâneas, avaliando o potencial de lixiviação e percolação dos principais agrotóxicos aplicados na região.

- Otimizar metodologia para a análise multi-resíduos dos agrotóxicos aldibarbe, carbofuran carbaril, atrazina e trifluralina, utilizando cromatografia liquida de alta eficiência com detecção ultravioleta/visível (LC - UV/Vis.).

- Desenvolver e otimizar metodologia para a análise multi - resíduo dos agrotóxicos aldicarbe, aldicarbe sulfona, carbaril, carbofurano, 3-hidroxi-carbofurano, metomil, simazina e trifluralina, utilizando cromatografia liquida de alta eficiência acoplada a espectrometria de massas Tandem (LC - MS/MS).

- Caracterizar as variáveis físico-químicas, quanto ao parâmetro agrotóxico, da água superficial (ou água bruta), nas áreas de 
captação de água destinadas ao abastecimento publico e, na água tratada das estações de tratamento de água operadas pela Sabesp, pertencentes à Bacia Hidrográfica do Rio Ribeira de Iguape.

- Avaliar a distribuição espacial e temporal dos agrotóxicos na bacia hidrográfica do rio Ribeira de Iguape e na água tratada, contribuindo para a implantação, complementação e revisão da Portaria $\mathrm{n}^{\circ}$ 518/MS/04.

\subsection{Análise crítica da legislação que estabelece o controle de qualidade das águas destinadas ao consumo humano}

A análise crítica da legislação que estabelece o controle de qualidade das águas foi realizada após várias discussões técnicas e elaboração de dois "workshop" com especialistas do setor de saneamento básico, principalmente do estado de São Paulo. Foram apresentadas e discutidas as avaliações feitas pelos técnicos dos laboratórios de controle sanitário e da produção do setor de saneamento da SAPESP, transmitidos pelos respectivos gerentes de todas as Unidades de Negócios da SABESP do Estado de São Paulo.

Foram comparados e discutidos os parâmetros estabelecidos para os padrões de potabilidade com as outras legislações como: a Portaria no 36/MS/90, Decreto Estadual/ SP no 12.486/78, guia para a qualidade de água potável da Organização Mundial da Saúde - OMS/95, os padrões de potabilidade de água aconselháveis a saúde, recomendados pela Agência de Proteção ao Meio Ambiente do Estados Unidos - EPA/03, bem como com os padrões estabelecidos para as classes dos rios, a Resolução CONAMA no 20/86.

\subsection{Reconhecimento da área de estudo}

O reconhecimento da área piloto, principalmente quanto ao uso e ocupação do solo, foi realizado por meio de visitas aos pontos de captação de água na bacia e respectivas Estações de Tratamento de Água - ETAs da Unidade de Negócio do Vale do Ribeira / Litoral Sul da SABESP. 
A partir dos dados históricos da SABESP, obtidos na Unidade de Negócios do Vale do Ribeira, foi realizado uma avaliação prévia dos parâmetros $\mathrm{pH}$, cor , turbidez e alcalinidade da água superficial e tratada da região, no período de 1996-2000.

Os dados referentes a agricultura local e do uso de agrotóxico foram obtidos a partir do projeto LUPA (Levantamento das Unidades de Produção Agropecuária) e no Escritório Regional da Coordenadoria de Assistência Técnica Integral- CATI, apresentado e discutido, no item 6.1 do Capítulo dos Resultados e Discussão.

Visando obter uma interação maior com a comunidade local do Vale do Ribeira, foi realizado em conjunto com o Comitê de Bacia do Vale do Ribeira o $1^{\circ}$ Seminário da Qualidade da Água do Rio Ribeira de Iguape, Registro-SP, $11 / 02 / 03$.

Na escolha dos principais parâmetros indicadores de contaminação por atividade agrícola na bacia foram observados além da legislação vigente, o uso e ocupação do solo, a inexistência de estudos na área e a nível estadual e federal, a necessidade do monitoramento quanto aos padrões de potabilidade, o aumento de interesse nos estudos de monitoramento dos orgãos ambientais internacionais, o grande volume de importação e exportação de agrotóxicos e o impacto do agronegócio no desenvolvimento do país.

\subsubsection{Análise das condições climáticas}

Consultando-se o banco de dados do Centro Integrado de Informações agrometeorológicos (CIIAGRO), na resenha agrometeorológica no item lista, consulta por Unidade de Gerenciamento dos Recursos Hídricos, foram levantadas informações sobre as condições climáticas da região.

O Centro Integrado de Informações Agrometeorológicos (CIIAGRO) foi criado em 1988 com a finalidade de operacionalizar e disponibilizar informações e aconselhamento às atividades agrícolas com base nos parâmetros 
agrometeorológicos e previsão do tempo. As atividades agrícolas que o CIIAGRO procura dar suporte são: calendário agrícola, preparo do solo, aplicação de produtos químicos agrícolas, monitoramento de irrigação, datas de maturação e colheita, controle e manejo de pragas e doenças vegetais, transporte de produtos agrícolas, operações florestais (incêndios, geadas e outros fenômenos adversos) manejo agrícola e outras atividades correlatas. Duas vezes por semana são coletados os dados diários de temperatura máxima e mínima do ar do período anterior e a precipitação acumulada. Estes dados geram as informações e aconselhamento agrometeorológico (CIIAGRO, 2003).

Para este trabalho foram consultados os dados sobre as sete estações meteorológicas situadas em diferentes pontos da bacia, nos municípios de Cananéia, Eldorado, Miracatu, Pariquera-Açu, Registro, Sete Barras e duas estações em Jacupiranga.

A resenha agrometeorológica do Estado de São Paulo é a síntese mensal dos elementos meteorológicos observados nas localidades do Estado de São Paulo e apresenta uma comparação com os valores médios históricos ou normais das mesmas localidades. Os elementos meteorológicos utilizados para cálculo são a temperaturas máxima e mínima do ar e precipitação pluviométrica.

\subsection{Análise do risco de contaminação por agrotóxicos}

\subsubsection{Avaliação do potencial de lixiviação e percolação dos agrotóxicos}

A primeira etapa de um estudo sobre a possibilidade de contaminação aquática ocorrida em determinada região por agrotóxicos tem como base: o levantamento das informações sobre a região como, o uso e ocupação do solo da região, tipo e quantidade de agrotóxicos aplicados; características ambientais e propriedades físico-químicas dos princípios ativos usados, de modo a permitir avaliar quais pesticidas apresentam a possibilidade de contaminar o ambiente aquático (Albanis et al, 1998; Dores \& Freire, 2001; Katsuóka, 2001). 
O objetivo deste estudo foi realizar uma análise do risco potencial de contaminação dos agrotóxicos, utilizados na região da Bacia Hidrográfica do Rio Ribeira de Iguape, em águas superficiais e subterrâneas. Foram aplicados critérios de avaliação desenvolvidos pela EPA, Goss (1992) e avaliada as características físico-químicas dos produtos utilizados consultando a literatura existente (Cohen et al., 1995; Goss, 1992; Dores \& Freire, 2001; Rao \& Hornsby, 2003; Bicki, 2004).

A cultura de banana é atividade econômica mais importante da região, sendo responsável por cerca de $90 \%$ do consumo de agrotóxicos. Os produtos mais usados e aqui avaliados são os listados na TAB.12 (página 77). Dados referentes a estimativa de área plantada foram levantados junto ao projeto LUPA da C.A.T.I (2001). A aplicação dos agrotóxicos nas culturas de banana, na região, está concentrada majoritariamente nas empresas prestadoras de serviços por via aérea (APÊDICE C, foto 8), segundo o relatório da Coordenadoria de Defesa Agrícola ${ }^{2}$.

Para a avaliação dos riscos de contaminação de águas subterrâneas na região, foram usados os critérios de "screening", descritos a seguir:

- Critérios da Agência de Proteção Ambiental dos Estados Unidos EPA (Cohen et al., 1995; Goss, 1992,);

- GUS - Índice de vulnerabilidade de águas subterrâneas "Groundwater Ubiquity Score" - (Bicki, 2004; Rao\& Hornsby, 2003; Cohen et al, 1995; van der Werf, 1996).

Para avaliar as possibilidades dos agrotóxicos atingirem as águas superficiais, foi utilizado o método de Goss (1995). Utilizando informações sobre os princípios ativos como a solubilidade em água, o coeficiente de adsorção à matéria orgânica do solo, meia vida do agrotóxico no solo e na água; pluviometria

\footnotetext{
${ }^{2}$ Coordenadoria de Defesa Agropecuária - Escritório de defesa agropecuária de Registro. Eng. Agr, Gilmar Gilberto Alves, 2001.
} 
anual, tipo de solo, etc. $O$ índice de vulnerabilidade de águas subterrâneas é calculado também por meio da meia vida do composto no solo e do coeficiente de adsorção à matéria orgânica do solo enquanto que para a água superficial, são levados em conta além da meia vida, a solubilidade em água, isto é, o potencial de transporte. A seguir são descritos detalhadamente os critérios utilizados.

\section{a) Critérios adotado pela EPA}

Os critérios de "screening" aplicados pela EPA para a análise preliminar de riscos de contaminação de águas subterrâneas por agrotóxicos são:

Características dos agrotóxicos:

- solubilidade em água: $>30 \mathrm{mgL}^{-1}$

- coeficiente de adsorção à matéria orgânica do solo: Koc < 300-500

- constante da Lei de Henry: $\mathrm{K}_{\mathrm{H}}<9,9 \times 10^{-10} \mathrm{atmm}^{3} \mathrm{~mol}^{-1}$

- especiação: negativamente carregado a pH normal do ambiente $(5-8)$

- Meia-vida no solo: > 2-3 semanas

- Meia-vida na água: > 25 semanas

- Condições de campo (que favorecem a percolação no solo):

- Pluviosidade anual: $>250 \mathrm{~mm}$

- Aqüífero não confinado

- Solo poroso

\section{b) Índice de vulnerabilidade de águas subterrâneas - GUS}

Este índice é calculado por meio dos valores de meia-vida dos compostos no solo $\left(\mathrm{DT}_{50}\right)$ e do coeficiente de adsorção à matéria orgânica do solo (Koc), não levando em consideração outras propriedades como solubilidade em água. Portanto: $\mathrm{GUS}=\log \left(\mathrm{DT}_{50}\right) \times\left(4-\log \mathrm{K}_{\mathrm{oc}}\right)$. 
As faixas de classificação dos compostos de acordo com sua tendência à lixiviação no solo, são:

- GUS $<1,8$ - não sofre lixiviação

- $1,8<$ GUS $<2,8$ - faixa de transição

- GUS > 2,8 - provável lixiviação.

c) Método de Goss

Os critérios utilizados para avaliação do potencial de contaminação de águas superficiais estão resumidamente descritos na TAB.8. As substâncias que não se enquadram em nenhum dos critérios são consideradas como tendo potencial médio de contaminação para águas superficiais.

TABELA 8 - Critérios para avaliação do potencial de contaminação de águas superficiais, conforme método de Goss(1992).

\begin{tabular}{|c|c|c|c|c|}
\hline $\begin{array}{l}\text { Potencial de } \\
\text { transporte } \\
\text { associado ao } \\
\text { sedimento }\end{array}$ & $\begin{array}{c}\text { Potencial de } \\
\text { transporte } \\
\text { dissolvido em } \\
\text { água }\end{array}$ & $\begin{array}{l}\text { Meia-vida no } \\
\text { solo em dias }\end{array}$ & Koc & $\begin{array}{l}\text { Solubilidade } \\
\text { em água } \\
\left(\mathrm{mgL}^{-1}\right)\end{array}$ \\
\hline Alto & --- & $\geq 40$ & 1.000 & --- \\
\hline Alto & --- & $\geq 40$ & $\geq 500$ & $\leq 0,5$ \\
\hline Baixo & --- & $<1$ & --- & --- \\
\hline Baixo & --- & $\leq 2$ & $\leq 500$ & \\
\hline Baixo & --- & $\leq 4$ & $\leq 900$ & $\geq 0,5$ \\
\hline Baixo & --- & $\leq 40$ & $\leq 500$ & $\geq 0,5$ \\
\hline Baixo & --- & $\leq 40$ & $\leq 900$ & $\geq 2$ \\
\hline-- & Alto & $>35$ & $<100.000$ & $\geq 1$ \\
\hline-- & Alto & $<35$ & $\leq 700$ & $\geq 10 \mathrm{e} \leq 100$ \\
\hline-- & Baixo & --- & $\geq 100.000$ & --- \\
\hline --- & Baixo & $\leq 1$ & $\geq 1.000$ & --- \\
\hline-- & Baixo & $<35$ & --- & $<0,5$ \\
\hline \multicolumn{5}{|c|}{ Médio: Para todas as outras situações } \\
\hline
\end{tabular}


5.4 Otimização de metodologia para a análise multi-resíduos utilizando Cromatografia líquida de alta eficiência (LC) com detecção ultravioleta/visível (UV/vis) e espectrometria de massas em Tandem (MS/MS)

\subsubsection{Equipamento e materiais}

- Cromatógrafo líquido de alta eficiência LC modelo LC - 10Ai da Shimadzu com duas bombas peristálticas de fluxo constante, programador de gradiente para dois solventes, um injetor Rheodyne

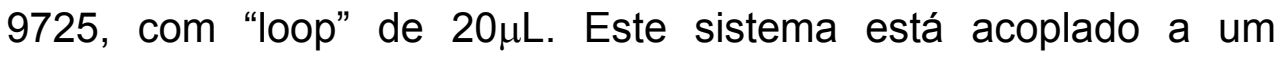
detector UV/visível SPD 10Ai da Shimadzu e um microprocessador de dados equipado com o programa CLASSLC10/M10, também da Shimadzu;

- Software Validation (Shimadzu);

- Coluna de fase reversa Shim-Pach CCL-ODS C $_{18}(150 \times 4,6 \mathrm{~mm}$ ID $5 \mu \mathrm{m})$ Shimadzu;

- Pré-coluna G-ODS $C_{18}(10$ x 4,0mm ID 5 $\mu \mathrm{m})$ Shimadzu;

- Cromatógrafo líquido de alta eficiência LC com injeção automática (auto sampler) - 20 $\mu \mathrm{L}$ - e bombas - Agilente série 1100 - G1311A;

- Coluna de fase reversa MetaChem ODS-3 - 3u - 75 X 4,6mm Varian.

- Espectrômetro de massas triploquadrupolo - AB Sciex Instruments modelo - API4000;

- Bomba de infusão - Harvard apparatus - Pump 11;

- Sistema purificador de água Easypure RF (Barnestd);

- Colunas de SPE ENVI $\mathrm{C}_{18} 500 \mathrm{mg} 3 \mathrm{~mL}$ (polipropileno) Supelco;

- Sistema de extração SPE a vácuo desenvolvido no laboratório (Lebre, 2000); 
- Sistema de filtração de soluções em membranas a vácuo (Santórios);

- Papel de filtro ou membrana $47 \mathrm{~mm}(0,45 \mu \mathrm{m})$, Santórios;

- Bomba de vácuo isenta de óleo, Fanen;

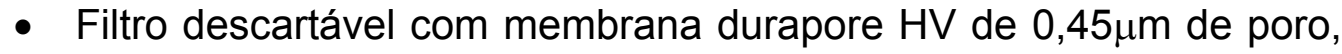
24mm de diâmetro, corpo de polietileno, estéril da MILLIPORE;

- Balança analítica e vidraria básica de laboratório analítico;

- Seringa de volume $50 \mu \mathrm{L}$, Hamilton;

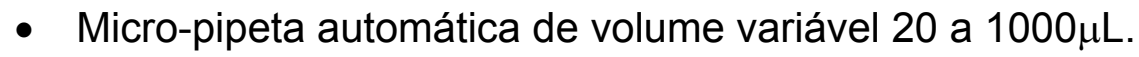

As vidrarias foram lavadas da seguinte forma: enxaguadas com extran, lavadas com solução sulfocrômica, enxaguadas com água destilada e depois com acetona e secas em estufa.

\subsubsection{Reagentes e soluções}

Todos os reagentes utilizados foram de grau analítico cromatográfico ou compatível, de procedência: EM Merck, Mallinckrodt Nanograde, Merck, J.T. Baker, Ciba-Geigy e Institut of Organic Industrial Chemistry.

- Água ultrapura de baixa condutividade, inferior a $1 \mu \mathrm{Scm}^{-1}$;

- Acetonitrila;

- Metanol;

- Acetonitrila; solução $50 \%(\mathrm{v} / \mathrm{v})$ acetonitrila e água;

- Solução de ácido monocloroacético $2,5 \mathrm{molL}^{-1}$ (118g do ácido em $500 \mathrm{~mL}$ de água);

- Solução de acetato de potássio $2,5 \mathrm{molL}^{-1}(122,5 \mathrm{~g}$ do sal em $500 \mathrm{~mL}$ de água);

- Solução tampão ácido monocloroacético $\left(2,5 \mathrm{molL}^{-1}\right) /$ acetato de potássio $\left(2,5 \mathrm{molL}^{-1}\right) \mathrm{pH} 3(312 \mathrm{~mL} / 200 \mathrm{~mL} \mathrm{v} / \mathrm{v})$; 
- tiossulfato de sódio;

- Padrões de referência com certificados de purezas: aldicarbe $99 \%$, atrazina $99,8 \%$, carbaril $99,8 \%$, carbofurano $99,9 \%$, simazina $99,8 \%$ e trifluralina $99,5 \%$;

- Solução padrão estoque (individual) à concentração de $10 \mathrm{mgL}^{-1} \mathrm{em}$ acetonitrila;

- Solução padrão intermediária contendo todos os compostos à concentração de $1,0 \mathrm{mgL}^{-1} \mathrm{em}$ acetonitrila (ACN);

- Solução padrão, na concentração de $100 \mu \mathrm{gL}^{-1}$, dos padrões de aldicarbe sulfona, 3-hidroxi-carbofurano e metomil, fornecidos pela EMBRAPA. A partir desta foram feitas todas as diluições necessárias, para a realização do trabalho, em solução $\mathrm{ACN} / \mathrm{H}_{2} \mathrm{O}$ $50 \%(\mathrm{v} / \mathrm{v})$;

Observação: Todas as soluções padrão preparadas devem ser mantidas no congelador e na ausência de luz. Estas soluções, armazenadas adequadamente, são estáveis por 1 ano (Barcelo, 1993; Dean et al, 1996; Lebre, 2000).

Todos os resíduos gerados nas análises e lavagens de vidraria foram encaminhados para o laboratório de resíduos do Centro de Química e Meio Ambiente - CQMA - IPEN/CNEN - SP.

\subsubsection{Determinação de carbamatos, triazinas e nitroanilinas utilizando LC - UV/Visível}

A metodologia empregada neste trabalho foi desenvolvida por Lebre (2000), no laboratório da Divisão de Diagnóstico Ambiental do Centro de Química e Meio Ambiente do IPEN/CNEN - SP. Neste trabalho, esta metodologia foi otimizada para a determinação dos herbicidas atrazina, simazina e trifluralina e dos inseticidas aldicarbe, carbofurano e carbaril em amostras de águas, utilizando a extração em fase sólida (SPE) para pré-concentração e extração dos compostos, em conjunto com a cromatografia líquida de alta eficiência (LC) com 
detecção UV/visível. Utilizou-se o sistema off-line, onde a amostra é extraída separadamente e posteriormente uma alíquota do extrato é injetada no cromatógrafo, com o objetivo de avaliar o comprometimento da qualidade da água destinada a captação e distribuição de água potável.

\section{a) Extração de fase sólida:}

As amostras foram submetidas à extração de fase sólida - SPE, em colunas de polipropileno de $3 \mathrm{~mL}$ (preenchida com $500 \mathrm{mg}$ da fase $\mathrm{C}_{18}$ ), procedendo-se da seguinte forma: as colunas foram condicionadas com $30 \mathrm{~mL}$ de acetonitrila (ACN) e 3mL de água ultra-pura, para ativação dos sítios e eliminação de impurezas; em seguida, $250 \mathrm{~mL}$ da amostra foi extraída a um fluxo de 5,0 a $6,0 \mathrm{mLmin}^{-1}$. Antes da etapa de secura da coluna sob vácuo, $3 \mathrm{~mL}$ de água ultrapura foram adicionados para eliminação de interferentes. Os compostos foram eluidos da coluna adicionando-se 2 vezes o volume de $3 \mathrm{~mL}$ do solvente acetonitrila. Para análise no cromatógrafo líquido, o solvente foi evaporado até a secura em fluxo de nitrogênio, em seguida o resíduo foi diluído com $2 \mathrm{~mL}$ da solução $50 \%$ (v/v) acetonitrila e água e injetado um volume de $20 \mu \mathrm{L}$ no cromatógrafo líquido. Teve-se o cuidado de não deixar a coluna secar nas etapas de condicionamento, percolação da amostra e eliminação de interferentes. Ao adicionar-se o volume de solvente ou água nas etapas de extração, deixar este em contato por 2 minutos.

\section{b) Condições de operação do LC - UV/visível}

Para a separação dos compostos no cromatógrafo líquido, utilizou-se uma coluna de fase reversa $\mathrm{C}_{18}$, Shim-Pack CCL-ODS e uma pré-coluna G-ODS, ambas da Shimadzu. A eluição foi realizada utilizando-se um gradiente da fase móvel aumentando a composição do solvente orgânico em função do tempo de análise, como mostra a TAB.9.

As condições de operação do sistema foram:

Fluxo da fase móvel: $1,0 \mathrm{mLmin}^{-1}$;

Pressão: 96 kgfcm ${ }^{-2}$; 
Volume de injeção: $20 \mu \mathrm{L}$;

Detecção no ultravioleta: $220 \mathrm{~nm}$.

TABELA 9 - Programação do gradiente de eluição utilizando como fase móvel água (A) e acetonitrila (B)

\begin{tabular}{cccc}
\hline Tempo (min) & \% A & \% B & Curva \\
\hline 0 & 52 & 48 & ---- \\
\hline 4,5 & 52 & 48 & ---- \\
\hline 20,0 & 20 & 80 & Convexa* $^{*}$ \\
\hline 21,0 & 20 & 80 & ---- \\
\hline
\end{tabular}

${ }^{*}$ Curva de gradiente não linear, convexa inclinação de -8 .

\subsubsection{Determinação de carbamatos, triazinas e nitroanilinas utilizando o LC - MS/MS.}

A Espectrometria de massas começou a desenvolver-se no início do século $\mathrm{XX}$, quando foram construídos os primeiros espectrômetros de massas com base nas pesquisas de J.J Thomson em 1912 e F. W Aston em 1919. Após a invenção dos instrumentos de quadrupolo por W. Paul em 1953, a técnica tem se modificado rapidamente (Bustillos et al, 2003).

O espectrômetro de massas (MS) é um instrumento de análise que determina a massa molecular de compostos químicos de acordo com sua razão massa/carga ( $\mathrm{m} / \mathrm{z})$. Para tanto, os átomos e moléculas são ionizados e os íons produzidos podem ser controlados por campos magnéticos e/ ou elétricos que podem ser mantidos constantes ou variados rapidamente. Os íons são gerados a partir de uma perda ou ganho de carga e estes são acelerados e selecionados por sua razão $\mathrm{m} / \mathrm{z}$, por meio de um campo elétrico-magnético sob vácuo e finalmente detectados. O objetivo da MS é obter a massa molecular exata dos compostos analisados, a fim de identificar, caracterizar e quantificar os mesmos. Na FIG.12 é apresentado de forma esquemática um processo utilizando espectrômetro de massas. 
A Espectrometria de massas quando aliada à cromatografia líquida ou gasosa permite a detecção e determinação de várias substâncias presentes em uma mistura em uma única análise, com alto grau de precisão e sensibilidade.

Atualmente, instrumentos que associam LC - MS e técnicas de ionização a pressão atmosférica (API - Atmospheric Pressure lonization) como ionização por elétron spray (ESI - Electrospray Ionization), ionização química a pressão atmosférica (APCl - Atmospheric Pressure Chemical Ionization) fotoionização a pressão atmosférica (APPI - Atmospheric Pressure Photoionization) vêm aumentando significativamente a capacidade de detecção da cromatografia líquida em termos de seletividade e sensibilidade, e ampliando o campo de aplicação da cromatografia em análises ambientais. Principalmente, quando estes instrumentos estão associados com o "tandem mass spectrometry" espectrometria de massas com triploquadrupolo - (MS-MS), pois a fragmentação do composto torna-se uma ferramenta potente, aumentando a confiabilidade na determinação deste. Além de diminuir a razão sinal ruído no cromatograma diminuindo o limite de detecção (LOD). Estes instrumentos possibilitam a realização de análises rápidas com limites de detecção menores que $0,1 \mu \mathrm{gL}^{-1}$ utilizando volumes pequenos de amostra (Asperger et al, 2001; Henández et al, 2001; Azevedo et al, 2000; Neuhaus et al, 2002; Ohlenbusch et al, 2002; Goodiwin et al, 2003; Robb et al, 2000).

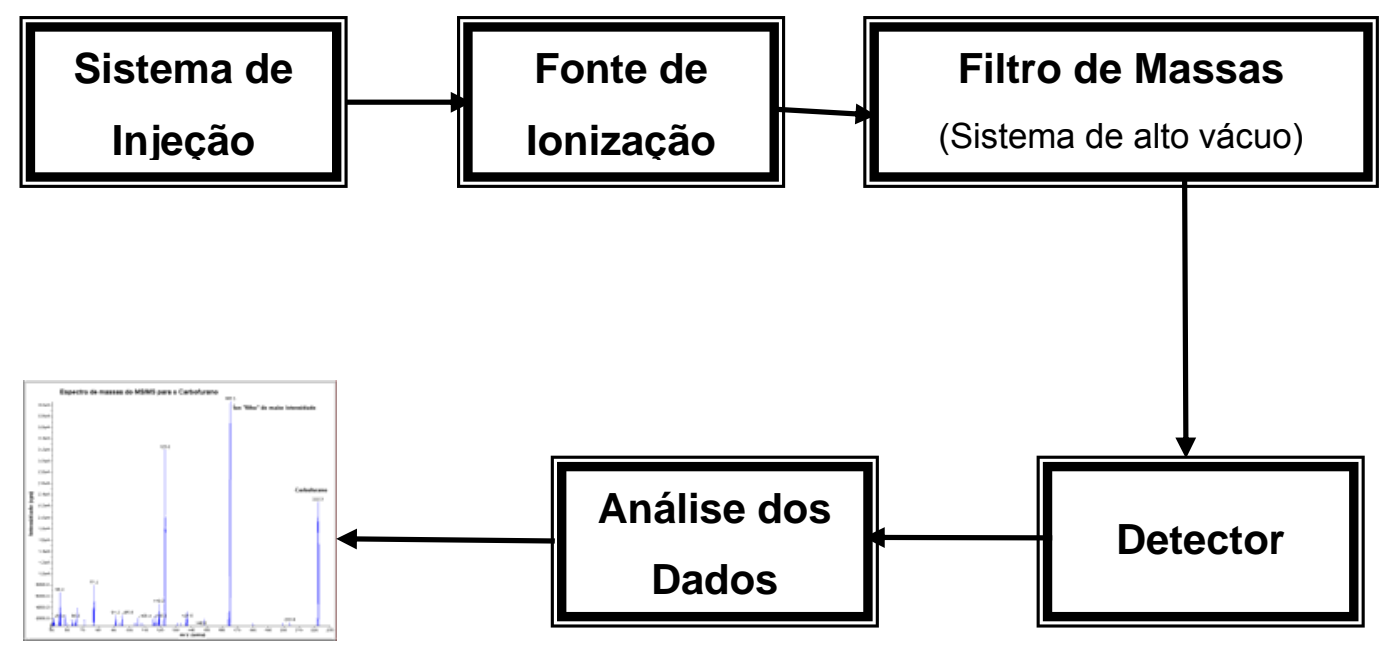

Espectro de Massas

FIGURA 12 - Representação esquemática de um processo utilizando espectrômetro de massas. 
Durante o ano de 2003 a Divisão de Diagnóstico Ambiental do IPEN/CNEN-SP fez uma parceria com a Applied Biosystems do Brasil Ltda recebendo um espectrômetro de massas - LC - MS/MS, modelo - API 4000, para desenvolvimento de metodologias analíticas e de recursos humanos. Devido ao grande interesse em aplicações ambientais, desenvolveu-se metodologia de análise multi-resíduos de agrotóxicos atendendo aos compostos: Aldicarbe, Aldicarbe sulfona, carbaril, carbofurano, 3-hidroxi-carbofurano, metomil, simazina e trifluralina.

A aplicação da metodologia foi feita em amostras de água superficial e tratada dos 10 pontos de coletas do Vale do Ribeira, coletadas em janeiro de 2004. O procedimento de coleta de amostra descrito anteriormente foi mantido, com exceção da adição da solução tampão de ácido monocloroacético e acetato de potássio.

Após a calibração do equipamento, tanto no modo negativo quanto no positivo, foi obtido um espectrômetro de massas no modo "multiple reaction monitoring" (MRM) detectando um MRM de transição para cada composto com um "dwell-time" de 200ms, no modo positivo, dos nove compostos estudados, na concentração de $100 \mu \mathrm{gL}^{-1}$ em solução $50 \%$ metanol e água, com adição de $0,1 \%$ de solução de acetato de amônia $0,001 \mathrm{molL}^{-1}$ por infusão, com uma razão de fluxo de $10 \mu \mathrm{Lmin}^{-1}$.

Em seguida, fez-se uma análise em MS/MS para se verificar o padrão de fragmentação dos analitos e determinou-se o melhor par iônico (íon precursor / íon produto) e as melhores energias de fragmentação para detecção dos íons selecionados. O ESI e APCI são processos complexos, têm muitos parâmetros instrumentais, os quais, influenciam drasticamente na eficiência da ionização. É requerida uma otimização cuidadosa do espectrômetro de massas para obter sua máxima sensibilidade. Isto inclui os ajustes dos parâmetros típicos da interface como a voltagem de ionização no ESI e a corrente na agulha de descarga do $\mathrm{APCl}$, respectivamente, pressão dos gases de spray/nebulização temperatura da interface e "declustering potencial" - potencial aplicado na interface do vácuo. 
Quando se trabalha no modo MS/MS a energia de colisão e a pressão do gás de colisão também são parâmetros importantes (Asperger et al, 2001).

Devido às características da metodologia desenvolvida, neste estudo incluíram-se mais três compostos o aldicarbe sulfona, produto de degradação do aldicarbe, o metomil e o metabólito do carbofurano o 3-hidróxi-carbofurano.

\subsection{Caracterização das Variáveis Físicas e Químicas}

\subsubsection{Locais de amostragem e periodicidade de coleta}

A caracterização das variáveis físicas e químicas da água bruta e da água tratada pertencente à bacia hidrográfica do Ribeira de Iguape, principalmente quanto à presença dos agrotóxicos, foi realizada nas áreas de captação superficial e nas estações de tratamento de água operadas pela Sabesp.

Estudos iniciais abordaram todos os 18 pontos de captação superficial e suas respectivas ETA's, sendo realizadas duas coletas. Após avaliação prévia, o estudo foi redirecionado, sendo avaliados em 10 sistemas, com adoção dos os seguintes critérios para escolha das estações de coleta: nove pontos com maior probabilidade de impacto agrícola e um ponto de amostragem em local totalmente preservado. Foram realizadas seis coletas, cinco no período de março de 2002 a fevereiro de 2003 e uma no mês de janeiro de 2004. No total de 152 amostras foram coletadas entre amostras de água superficial e tratada. Na TAB.10 é apresentada uma descrição dos pontos ou estações de coleta agrupadas por município.

Quanto à periodicidade de amostragens, foram realizadas coletas durante um ano em períodos distintos, abordando períodos chuvoso e seco: março de 2002 (11.03 a 14.03.2002); junho de 2002 (19.06 a 01.07.2002); setembro de 2002 (10.09 a 16.09.2002); novembro de 2002 (20.11 a 25.11.2002); fevereiro de 2003 (13.02 A 20.2.2003) e janeiro de 2004 (25.01 a 28.01.2004). 
TABELA 10 - Descrição e agrupamento dos locais de coleta nas diferentes áreas de captação de água superficial e respectivas ETA's.

\begin{tabular}{|c|c|c|c|c|}
\hline $\begin{array}{c}\text { Código de } \\
\text { amostragem } \\
\text { SABESP }\end{array}$ & Município & $\begin{array}{l}\text { Local de } \\
\text { Captação }\end{array}$ & $\begin{array}{l}\text { Coordenadas Geodésicas } \\
\text { dos pontos de coleta }\end{array}$ & $\begin{array}{c}\text { Classicação } \\
\text { do Corpo } \\
\text { d'água(*) }\end{array}$ \\
\hline LR 001 & Registro & $\begin{array}{l}\text { Rio } \\
\text { Ribeira do } \\
\text { Iguape }\end{array}$ & $\begin{array}{c}\text { Captação } \\
\text { S: } 24^{\circ} 28^{`} 25^{\prime \prime} \text { WO: } 47^{\circ} 50^{`} 37^{\prime \prime} \\
\text { ETA } \\
\text { S: } 24^{\circ} 29^{\circ} 04^{\prime \prime} \text { WO: } 47^{\circ} 51^{\prime} 01^{\prime \prime}\end{array}$ & Classe 2 \\
\hline LR 005 & Sete Barras & $\begin{array}{l}\text { Ribeira do } \\
\text { Iguape }\end{array}$ & $\begin{array}{c}\text { Captação } \\
\text { S: } 24^{\circ} 23^{`} 33^{\prime \prime} \text { WO: } 47^{\circ} 55^{`} 43^{\prime \prime} \\
\text { ETA } \\
\text { S: } 24^{\circ} 23^{`} 31^{\prime \prime} \text { WO: } 47^{\circ} 55^{\prime} 44^{\prime \prime}\end{array}$ & Classe 2 \\
\hline LR 007 & Jacupiranga & Rio Canha & $\begin{array}{c}\text { Captação } \\
\text { S: } 24^{\circ} 43^{`} 03^{\prime \prime} \text { WO: } 47^{\circ} 59^{`} 58^{\prime \prime} \\
\text { ETA } \\
\text { S: } 24^{\circ} 42^{\prime} 33^{\prime \prime} \text { WO: } 48^{\circ} 00^{`} 40^{\prime \prime}\end{array}$ & Classe 2 \\
\hline LR 011 & Cajati & $\begin{array}{c}\text { Rio } \\
\text { Jacupiran- } \\
\text { guinha }\end{array}$ & $\begin{array}{c}\text { Captação } \\
\text { S: } 24^{\circ} 43^{`} 50^{\prime \prime} \text { WO: } 48^{\circ} 07^{`} 56^{\prime \prime} \\
\text { ETA } \\
\text { S: } 24^{\circ} 43^{`} 42^{\prime \prime} \text { WO: } 48^{\circ} 08^{`} 02^{\prime \prime}\end{array}$ & Classe 2 \\
\hline LR 012 & $\begin{array}{l}\text { Barra do } \\
\text { Turvo }\end{array}$ & $\begin{array}{l}\text { Rio Pardo } \\
\text { e Córrego } \\
\text { Chopim }\end{array}$ & $\begin{array}{c}\text { Captação } \\
\text { S: } 24^{\circ} 45^{`} 40^{\prime \prime} \text { WO: } 48^{\circ} 30^{\prime} 28^{\prime \prime} \\
\text { ETA } \\
\text { S: } 24^{\circ} 45^{\prime} 34^{\prime \prime} \text { WO: } 48^{\circ} 30^{\prime} 14^{\prime \prime}\end{array}$ & Classe 2 \\
\hline LR 013 & Cananéia & $\begin{array}{c}\text { Rio } \\
\text { Itapitangui }\end{array}$ & $\begin{array}{c}\text { Captação } \\
\text { S: } 24^{\circ} 55^{`} 58^{\prime \prime} \text { WO: } 47^{\circ} 57^{\prime} 41^{\prime \prime} \\
\text { ETA } \\
\text { S: } 24^{\circ} 55^{\prime} 58^{\prime \prime} \text { WO: } 47^{\circ} 57^{\prime} 41^{\prime \prime}\end{array}$ & Classe 2 \\
\hline LR 017 & Eldorado & $\begin{array}{l}\text { Rio } \\
\text { Ribeira do } \\
\text { Iguape }\end{array}$ & $\begin{array}{c}\text { Captação } \\
\text { S: } 24^{\circ} 31^{\circ} 09^{\prime \prime} \text { WO: } 48^{\circ} 066^{\prime} 54^{\prime \prime} \\
\text { ETA } \\
\text { S: } 24^{\circ} 31^{\prime} 13^{\prime \prime} \text { WO: } 48^{\circ} 06^{\prime} 53^{\prime \prime}\end{array}$ & Classe 2 \\
\hline LR 021 & $\begin{array}{c}\text { Pariquera - } \\
\text { Açu }\end{array}$ & $\begin{array}{l}\text { Córrego } \\
\text { Braço } \\
\text { Grande }\end{array}$ & $\begin{array}{c}\text { Captação } \\
\text { S: } 24^{\circ} 43^{`} 21^{\prime \prime} \text { WO: } 47^{\circ} 53^{`} 29^{\prime \prime} \\
\text { ETA } \\
\text { S: } 24^{\circ} 43^{\prime} 21^{\prime \prime} \text { WO: } 47^{\circ} 53^{\prime} 26^{\prime \prime}\end{array}$ & Classe 2 \\
\hline LR 022 & Juquiá & Rio Juquiá & $\begin{array}{c}\text { Captação } \\
\text { S: } 24^{\circ} 19^{`} 12^{\prime \prime} \text { WO: } 47^{\circ} 37^{`} 30^{\prime \prime} \\
\text { ETA } \\
\text { S: } 24^{\circ} 18^{`} 48^{\prime \prime} \text { WO: } 47^{\circ} 38^{`} 27^{\prime \prime}\end{array}$ & Classe 2 \\
\hline LR 026 & Miracatu & $\begin{array}{l}\text { Rio São } \\
\text { Lourenço }\end{array}$ & $\begin{array}{c}\text { Captação } \\
\text { S: } 24^{\circ} 16^{\prime} 24^{\prime \prime} \text { WO: } 47^{\circ} 27^{\prime} 09^{\prime \prime} \\
\text { ETA } \\
\text { S: } 24^{\circ} 16^{\prime} 48^{\prime \prime} \text { WO: } 47^{\circ} 27^{\prime} 00^{\prime \prime}\end{array}$ & Classe 2 \\
\hline LR 033 & Iguape & $\begin{array}{l}\text { Rio } \\
\text { Ribeira do } \\
\text { Iguape }\end{array}$ & $\begin{array}{c}\text { Captação } \\
\text { S: } 24^{\circ} 40^{`} 54^{\prime \prime} \text { WO: } 47^{\circ} 35^{`} 50^{\prime \prime} \\
\text { ETA } \\
\text { S: } 24^{\circ} 42^{`} 29^{\prime \prime} \text { WO: } 47^{\circ} 34^{`} 02^{\prime \prime}\end{array}$ & Classe 2 \\
\hline
\end{tabular}


TABELA 10 - Descrição e agrupamento dos locais de coleta nas diferentes áreas de captação de água superficial e respectivas ETA's (Continuação).

\begin{tabular}{|c|c|c|c|c|}
\hline $\begin{array}{l}\text { Código de } \\
\text { amostragem } \\
\text { SABESP }\end{array}$ & Município & $\begin{array}{l}\text { Local de } \\
\text { Captação }\end{array}$ & $\begin{array}{l}\text { Coordenadas Geodésicas } \\
\text { dos pontos de coleta }\end{array}$ & $\begin{array}{l}\text { Classicação } \\
\text { do Corpo } \\
\text { d'água(*) }\end{array}$ \\
\hline LR 044 & $\begin{array}{l}\text { Pedro de } \\
\text { Toledo }\end{array}$ & $\begin{array}{l}\text { Rio do } \\
\text { Peixe }\end{array}$ & $\begin{array}{c}\text { Captação } \\
\text { S: } 24^{\circ} 17^{\circ} 02^{\prime \prime} \text { WO: } 47^{\circ} 13^{`} 40^{\prime \prime} \\
\text { ETA } \\
\text { s: } 24^{\circ} 16^{\prime} 59^{\prime \prime} \text { WO: } 47^{\circ} 13^{\prime} 49^{\prime \prime}\end{array}$ & Classe 2 \\
\hline LR 045 & Juquitiba & $\begin{array}{l}\text { Córrego } \\
\text { dos } \\
\text { Godinhos }\end{array}$ & $\begin{array}{c}\text { Captação } \\
\text { S: } 23^{\circ} 56^{\circ} 00^{\prime \prime} \text { WO: } 47^{\circ} 03^{`} 38^{\prime \prime} \\
\text { ETA } \\
\text { S: } 23^{\circ} 55^{\prime} 51^{\prime \prime} \text { WO: } 47^{\circ} 03^{`} 55^{\prime \prime}\end{array}$ & Classe 2 \\
\hline LR 049 & $\begin{array}{l}\text { S. Lourenço } \\
\text { da Serra }\end{array}$ & $\begin{array}{l}\text { Rio São } \\
\text { Lourenço }\end{array}$ & $\begin{array}{c}\text { Captação } \\
\text { S: } 23^{\circ} 51^{\prime} 04^{\prime \prime} \text { WO: } 46^{\circ} 56^{`} 34^{\prime \prime} \\
\text { ETA } \\
\text { S: } 23^{\circ} 51^{\prime} 07^{\prime \prime} \text { WO: } 46^{\circ} 56^{`} 39^{\prime \prime}\end{array}$ & Classe 2 \\
\hline LR 050 & $\begin{array}{l}\text { Paiol do } \\
\text { Meio }\end{array}$ & $\begin{array}{l}\text { Rio São } \\
\text { Lourenço }\end{array}$ & $\begin{array}{c}\text { Captação } \\
\text { S: } 23^{\circ} 52^{\prime} 56^{\prime \prime} \text { WO: } 46^{\circ} 58^{`} 28^{\prime \prime} \\
\text { ETA } \\
\text { S: } 23^{\circ} 52^{\prime} 57^{\prime \prime} \text { WO: } 46^{\circ} 58^{`} 28^{\prime \prime}\end{array}$ & Classe 2 \\
\hline LR 068 & Iporanga & $\begin{array}{c}\text { Rio } \\
\text { Iporanga }\end{array}$ & $\begin{array}{c}\text { Captação } \\
\text { S: } 24^{\circ} 34^{\prime} 49^{\prime \prime} \text { WO: } 48^{\circ} 35^{\prime} 25^{\prime \prime} \\
\text { ETA } \\
\text { S: } 24^{\circ} 35^{\prime} 06^{\prime \prime} \text { WO: } 48^{\circ} 35^{\prime} 46^{\prime \prime}\end{array}$ & Classe 2 \\
\hline LR 142 & $\begin{array}{l}\text { Bairro do } \\
\text { Turvo }\end{array}$ & Rio Turvo & $\begin{array}{c}\text { Captação } \\
\text { S: } 23^{\circ} 53^{\prime} 48^{\prime \prime} \text { WO: } 47^{\circ} 30^{`} 44^{\prime \prime} \\
\text { ETA } \\
\text { S: } 23^{\circ} 53^{`} 55^{\prime \prime} \text { WO: } 47^{\circ} 31^{`} 29^{\prime \prime}\end{array}$ & Classe 2 \\
\hline LR 043 & Itariri & $\begin{array}{l}\text { Manancial } \\
\text { de Serra }\end{array}$ & $\begin{array}{c}\text { Captação } \\
\text { s: } 24^{\circ} 18^{\prime} 17^{\prime \prime} \text { WO: } 47^{\circ} 10^{`} 47^{\prime \prime} \\
\text { ETA } \\
\text { S: } 24^{\circ} 18^{\prime} 09^{\prime \prime} \text { WO: } 47^{\circ} 10^{\prime} 39^{\prime \prime}\end{array}$ & $\begin{array}{l}\text { Classe } \\
\text { Especial }\end{array}$ \\
\hline
\end{tabular}

Os pontos de coleta monitorados, durante todo o período de estudo (março de 2002 a fevereiro de 2003), localizam-se nos municípios de Barra do Turvo, Cajati, Cananéia, Eldorado, Iguape, Iporanga, Juquitiba, Juquiá, Registro e Sete Barras. A localização da Bacia hidrográfica do Ribeira de Iguape - SP com a indicação dos municípios e respectivos pontos de coleta estão apresentados na FIG.13. 


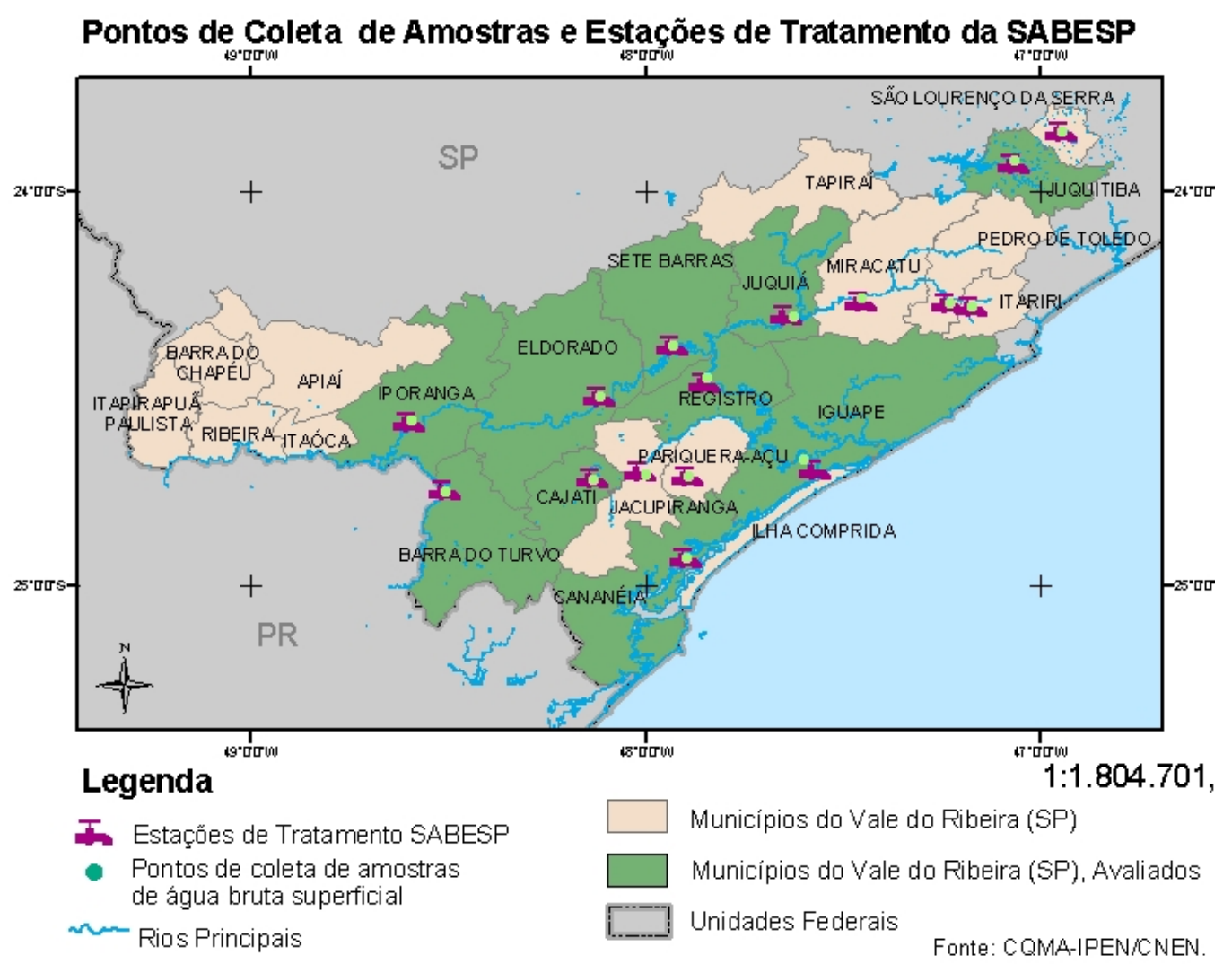

FIGURA 13 - Mapa da Bacia Hidrográfica do Ribeira de Iguape com identificação das estações de coleta: captações superficiais e ETAs.

\subsubsection{Coleta, preservação e análise das amostras de água}

As amostragens foram realizadas com auxílio da equipe de coletas da Unidade de Negócios da SABESP de Registro, após avaliações prévias da equipe do IPEN, de acordo com o Manual de coleta da CETESB (1985).

Foram coletadas amostras de água superficial e água tratada, em vidros âmbar de $1 \mathrm{~L}$ contendo $30 \mathrm{~mL}$ de solução tampão $\mathrm{pH} 3 \mathrm{e} \cong 1,00 \mathrm{~g}$ de tiossulfato de sódio (Standard Methods, 1997). As amostras, devidamente identificadas, foram mantidas sob refrigeração à temperatura de $4^{\circ} \mathrm{C}$.

Nos laboratórios do Controle Sanitário da SABESP de Registro foram analisados os parâmetros físico-químicos de cor, turbidez e pH. Em seguida as amostras foram para os laboratórios do IPEN, onde foram filtradas em membranas de $0,45 \mu \mathrm{m}$, para a eliminação de partículas em suspensão. 
Separaram-se alíquotas de $250 \mathrm{~mL}$, mantidas em pH 3, para a determinação dos resíduos de agrotóxicos. Estas foram submetidas à extração em fase sólida $\mathrm{SPE}$, em colunas de polipropileno de $3 \mathrm{~mL}$ (preenchida com $500 \mathrm{mg}$ da fase $\mathrm{C}_{18}$ ).

Analisaram-se os pesticidas atrazina, simazina, trifluralina, albicabe, carbaril e carbofurano por cromatografia líquida de alta eficiência com detecção UV/vis (Lebre, 2000; Katsuóka, 2001; PIRES et al, 2002), conforme descrito no item 5.4.3.

As amostras coletadas no mês de janeiro de 2004 foram analisadas em HPLC-UV/vis e também utilizando-se a cromatografia líquida de alta eficiência acoplada a espectrometria de massas Tandem (LC-MS/MS) (Lebre, 2004; Marques et al, 2004), conforme descrito no item 5.4.4. 


\section{RESULTADOS E DISCUSSÃO}

\subsection{Avaliação da área de estudo}

\subsubsection{Uso e ocupação do solo}

O Vale do Ribeira possui todas as condições ambientais para se caracterizar como uma das regiões mais prósperas de nosso país, mas até hoje tem permanecido à margem do desenvolvimento nacional.

Este apresenta características bastante singulares, como os mais baixos índices de desenvolvimento do estado, uma economia baseada principalmente na agricultura (banana, chá e arroz), mineração e extrativismo vegetal (palmito). Os parâmetros sócio-econômicos e demográficos apresentam uma imagem contrastante com o resto do estado. Além disso, é uma região peculiar por ser uma das áreas menos urbanizadas do estado. Apesar da capital regional do Vale do Ribeira, o município de Registro, estar localizada a menos de $200 \mathrm{~km}$ da Região Metropolitana de São Paulo, a industrialização nunca foi importante no Vale, sua contribuição não passou de 0,3\%, no período de 1985 a 1996. Razões históricas, dificuldades de acesso e condições naturais adversas às atividades econômicas garantiram até hoje um relativo isolamento e a preservação dos seus recursos naturais (Hogan et al, 2001).

Atualmente, a agricultura é a principal atividade econômica, destacando-se as culturas da banana e do chá pela área que ocupam e importância comercial que representam, além de absorverem a maior parte da mão-de-obra local. Embora, passe por sérias dificuldades de expansão e modernização, configurando-se em problemas estruturais que determinam pouco dinamismo econômico.

O setor secundário regional apresenta reduzido número de estabelecimentos e baixa absorção de mão-de-obra. Destacam-se a exploração do fosfato e do calcário, predominantemente em Cajati, com a Serrana S/A de Mineração e em Apiaí com a empresa de cimento Portland Eldorado, do grupo 
Moinho Santista e Camargo Corrêa, respectivamente. Os municípios de Eldorado, Juquiá e Registro comportam pequenas indústrias em setores diversificados (CETEC, 2000).

A região da Bacia do Ribeira de Iguape / Litoral Sul responde por $65,87 \%$ da área ocupada por vegetação nativa do estado de São Paulo. A Mata Atlântica no Vale do Ribeira ocupa mais de um milhão de hectares de vegetação nativa. Este indicador variando entre 13\% em Ribeira a 90\% em Pedro de Toledo (dados de 1988). Abrange várias unidades de conservação como parques estaduais estações ecológicas, áreas de proteção ambiental, com instrumento legal de criação (SEDAE, 2002).

Recentemente o INPE (2004) disponibilizou informações detalhadas (Atlas dos Municípios da Mata Atlântica - FIG.14) sobre a situação da Mata Atlântica em dez dos 17 estados que são abrangidos pelo bioma: Bahia, Minas Gerais, Goiás, Mato Grosso do Sul, Espírito Santo, Rio de Janeiro, São Paulo, Paraná, Santa Catarina e Rio Grande do Sul. Neste relatório foi criado o Índice de Preservação da Mata Atlântica, indicador criado pela organização ambientalista, com o ranking dos municípios que mais possuem vegetação nativa da Mata Atlântica. Vários municípios pertencentes à Região do Ribeira de Iguape estão entre os de maior índice de preservação, alguns deles como Iporanga, com 98\% de mata preservada (INPE,2004).

Portanto, o turismo ecológico e a piscicultura são atividades com grandes chances de desenvolvimento na região, desde que, seus planejamentos sejam adequados e sustentáveis capazes de gerar renda sem comprometer a conservação do meio ambiente.

O Vale do Ribeira é apresentado como potencial modelo brasileiro de desenvolvimento sustentado. Posiciona-se em local privilegiado, entre duas importantes capitais, São Paulo e Curitiba, e o acesso à região se dá por meio de rodovias e ferrovias. Por suas peculiaridades, a região concentra natureza e cultura para tornar-se importante pólo de desenvolvimento sustentado e do ecoturismo (CETEC, 2000). 


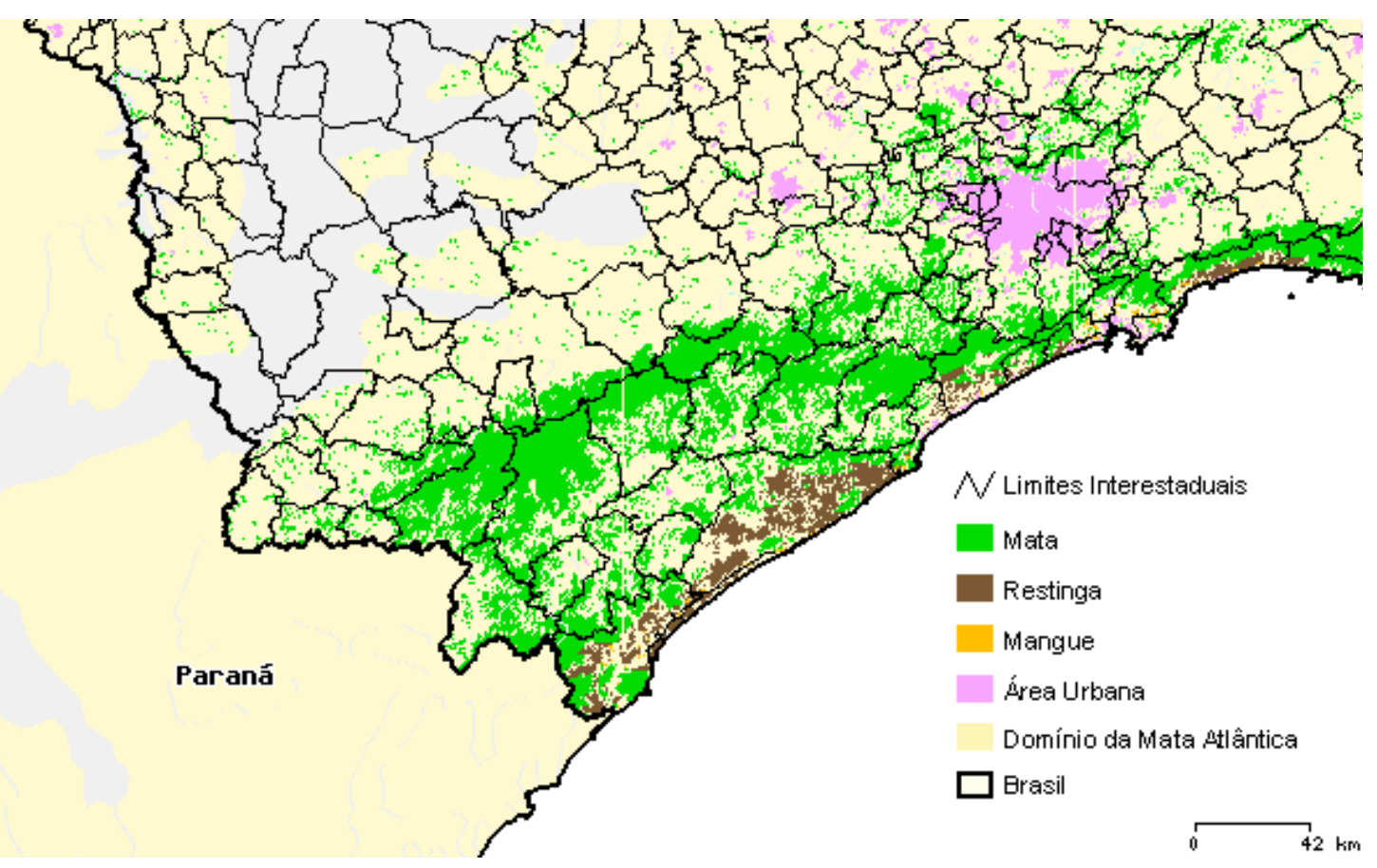

FIGURA 14 - Distribuição da Densidade de Mata Atlântica (INPE, 2004).

Na FIG.15 é apresentado um resumo das principais características quanto ao uso do solo no Vale do Ribeira (CATI, 2001). Com relação à capacidade do uso das terras, baseado nas características físicas dos terrenos tais como declividade do terreno, efeito do clima e outros, somente $6,28 \%$ das terras são consideradas terras aráveis; $12,18 \%$ terras para culturas permanentes, $10,97 \%$ para pastagens, $46,19 \%$ para pastagens ocasionais e reflorestamento e $24,37 \%$ como terras inaproveitáveis. Isso mostra a vocação florestal por excelência.

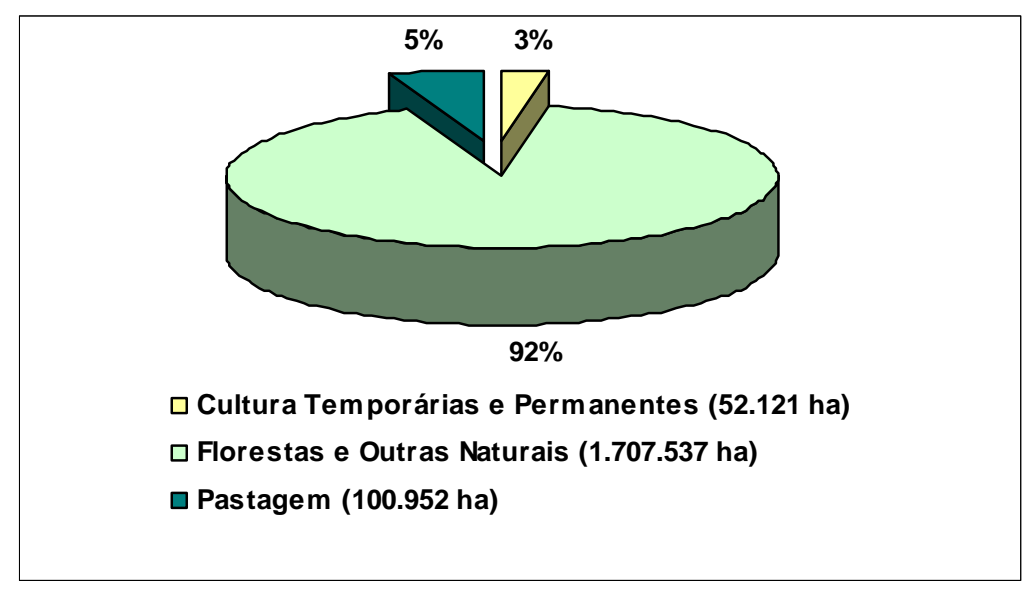

FIGURA 15 - Uso e ocupação do solo na Bacia Hidrográfica do Rio Ribeira de Iguape (CATI, 2001). 


\subsubsection{Agricultura e cobertura vegetal}

A cobertura vegetal natural compreende também as matas alteradas ainda não completamente descaracterizadas, tais como: mata, mata degradada ou em recuperação, séries iniciais de sucessão; várzea arbórea, várzea herbácea; floresta de encosta ou mata de encosta; floresta de transição; mata paludosa em solo turfoso; floresta de restinga; floresta de restinga degradada; brejo de restinga e mangue. O reflorestamento compreende formações florestais artificiais constituídas predominantemente por pinus e eucalyptus. As culturas perenes, culturas de ciclo longo, destacam-se a teicultura e a bananicultura (CETEC, 2004).

A teicultura corresponde a áreas com campos agrícolas de chá, algumas vezes associadas com capoeiras ou outros estágios de recuperação de mata. Na bananicultura é comum a associação a vegetação natural. A estrutura fundiária de grandes propriedades ocupa boa parte da área total. Culturas pequenas ou de médio porte, puras ou mistas são comuns na região, como tomate, pêssego, maracujá, feijão, gengibre, arroz e batata.

Devido à baixa fertilidade do solo, excesso de água, e limitações impostas pela mecanização (encharcamento e terrenos muito acidentados) a região possui pequenas áreas com solos do tipo muito bom e extensas áreas de solos apenas regulares para agricultura (CETEC, 2004; SMA, 1992).

Segundo o Projeto LUPA, as culturas com maior extensão de cultivo por hectare na Regional Agrícola de Registro, em ordem crescente, são: braquiária, banana, palmito, chá, pinus, eucalípto, milho, arroz, outros capins, maracujá, capim-gordura, tangerina, feijão, mandioca, seringueira, chuchu, outras culturas, capim-colonião, cacau, outras flores, laranja, cana-de-açúcar e capimnapier (CATI, 2004).

De modo geral, a agropecuária local utiliza tecnologia pouco desenvolvida, com baixo rendimento, ressentindo-se das limitações dos fatores solo, topografia e inundações, além dos já aludidos aspectos fundiários. 
As produções de banana e chá, da região, representam as maiores porcentagens da produção do estado de São Paulo. O extrativismo do palmito, embora quantitativamente expressivo quando comparado às produções estaduais, tem relativamente pequeno valor econômico para a região.

Segundo dados obtidos no Ministério da Agricultura, Pecuária e Abastecimento (2004), o Estado de São Paulo está entre os três maiores produtores de banana do país. O gráfico da FIG.16 mostra o perfil da produção de banana nos estados do Pará, São Paulo e Bahia, no período de 1992 a 2001.

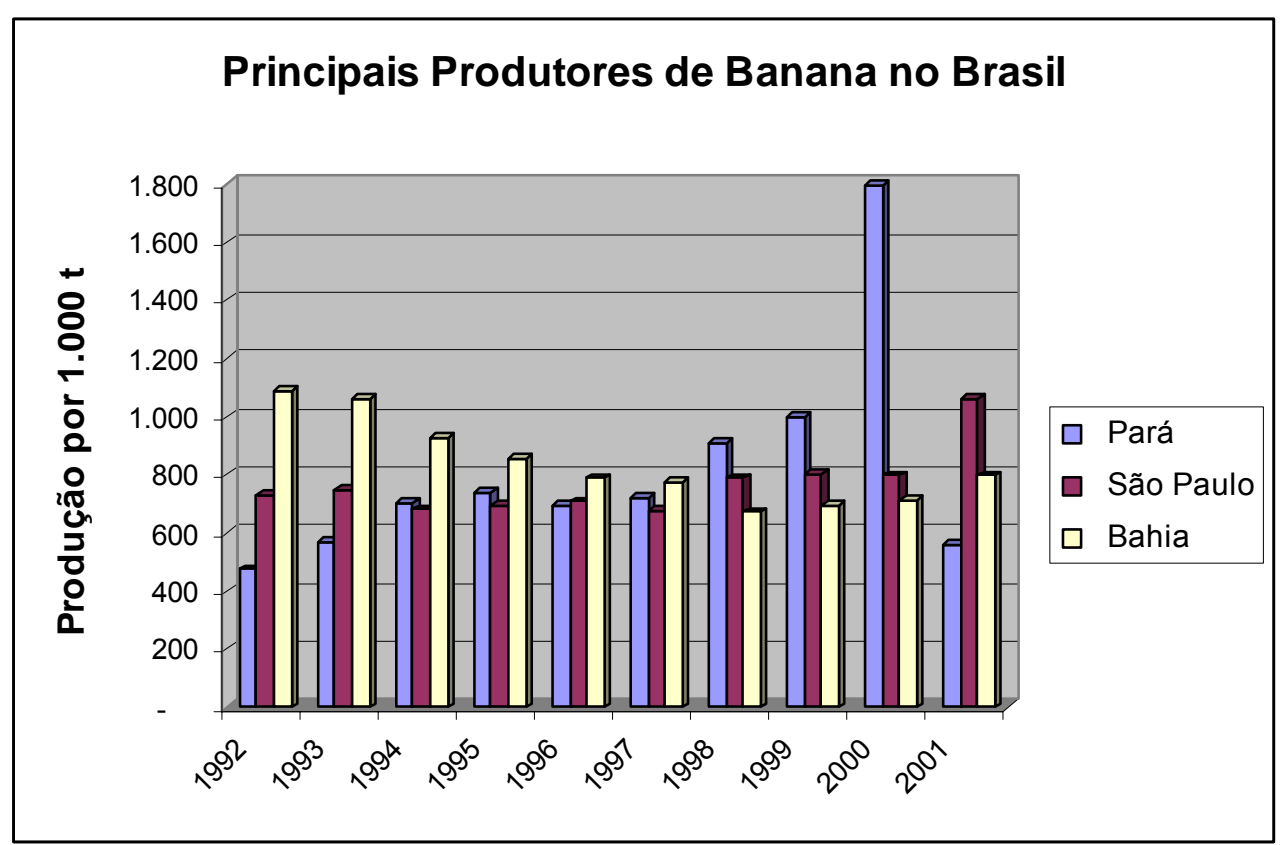

FIGURA 16 - Principais produtores de banana no Brasil, no período de 1992

a 2001 (Ministério da Agricultura, 2004; adaptado por Marques, M.N.).

A produção de bananas do estado de São Paulo é estimada em cerca de $\mathrm{R} \$ 413$ milhões. O Vale do Ribeira é responsável por $83 \%$ deste valor e a banana responde por $80 \%$ da produção agrícola da região (SEAA, 2004). A produção é estimada em um milhão toneladas/ano, com geração direta de 30.000 
empregos $^{3}$. Na TAB.11 são apresentadas as principais regionais agrícolas produtoras de banana no Estado.

TABELA 11 - Principais Regionais Produtoras de Banana do estado de São Paulo (C.A.T.I. - LUPA, 2004).

\begin{tabular}{ccc}
\hline Regional & Área Plantada (ha) & Área Plantada (\%) \\
\hline Assis & 400 & 0,60 \\
\hline Jaboticabal & 500 & 0,80 \\
\hline Sorocaba & 550 & 0,90 \\
\hline Catanduva & 620 & 1,20 \\
\hline Avaré & 777 & 1,27 \\
\hline Fernandópolis & 1.500 & 2,50 \\
\hline Jales & 1.700 & 2,80 \\
\hline São José Campos & 1.970 & 3,20 \\
\hline São Paulo & 6.800 & 11,00 \\
\hline Registro & 41.600 & 72,00 \\
\hline
\end{tabular}

\subsubsection{Uso de agrotóxico na região}

O uso de agrotóxicos foi introduzido na região do Vale do Ribeira na década de 60, estimulado pela Cooperativa Agrícola de Cotia - CAC, para uso no combate a pragas e doenças da bananicultura, visando obter produtos competitivos no mercado externo (SMA, 1992).

\footnotetext{
${ }^{3}$ Palestra ministrada pelo Eng. Agrônomo Luis Alberto Saez do Instituto Agronômico de Campinas - Unidade de Pesquisa e Desenvolvimento de Pariquera-Açu - S.A.A, 2001.
} 
Aproximadamente 4.000 propriedades rurais têm na cultura da banana sua principal atividade agrícola. Como conseqüência, ela é responsável por cerca de $90 \%$ do consumo de agrotóxicos na região ${ }^{4}$.

O Vale do Ribeira, principalmente na cultura da banana, utiliza alguns agrotóxicos que em qualquer situação de uso apresentam risco à saúde dos trabalhadores, da população e do meio ambiente. Os fungicidas representam o maior volume de agrotóxicos aplicados na região, como mostra a TAB.12.

TABELA 12 - Principais agrotóxicos comercializados no Vale do Ribeira².

\begin{tabular}{|c|c|c|c|c|}
\hline $\begin{array}{c}\text { AgROTÓXICOS } \\
\text { NOME } \\
\text { COMERCIAL }\end{array}$ & $\begin{array}{l}\text { PRINCÍPIO ATIVO } \\
\text { (ANVISA, 2004) }\end{array}$ & $\begin{array}{c}\text { CLASSE }^{(A)} \\
\text { TOXICOLÓ - } \\
\text { GICA }\end{array}$ & $\begin{array}{c}\text { QUANTIDADE } \\
\text { COMERCIALIZADA } \\
\text { NO ANO DE } 2000 \\
\left(\text { L.ano }^{-1}\right)\end{array}$ & $\begin{array}{c}\text { TIPO DE } \\
\text { AGROTÓXICO }\end{array}$ \\
\hline Óleo mineral & Hidrocarbonetos & IV & 1.800 .000 & Fungicida \\
\hline Tilt & Propiconazol & III & 20.000 & Fungicida \\
\hline Folicur & Tebuconazol & III & 4.000 & Fungicida \\
\hline Juno & Propiconazol & III & 4.000 & Fungicida \\
\hline Cercobin & Benzimidazoles & IV & 4.000 & Fungicida \\
\hline Priori & Azoxistrobina & III & 1.000 & Fungicida \\
\hline Furadan (líq.) & Carbofurano & $\mathrm{I}$ & 4.000 & Inset/Nemat \\
\hline Furadan (gran) & Carbofurano & III & 60.000 kg.ano-1 & Inset/Nemat \\
\hline Servin & Carbaril & II & 5.000 & Inset/Nemat \\
\hline Counter 50G & Terbufós & $\mathrm{I}$ & 2.000 & Inset/Nemat \\
\hline Gramoxone & Paraquate & II & 20.000 & Herbicidas \\
\hline Gramocil & Paraquate+Diuron & II & 60.000 & Herbicidas \\
\hline Roundup & Glifosato & IV & 30.000 & Herbicidas \\
\hline Finale & Glufosinato & IV & 25.000 & Herbicidas \\
\hline Zapp & Sulfosato & IV & 8.000 & Herbicidas \\
\hline
\end{tabular}

(A) Classe I - EXTREMAMENTE TóXICO; CLASSE II - ALTAMENTE TóXICO; CLASSE III - MEDIANAMENTE TÓXICO E CLASSE IV POUCO TÓXICO (PORTARIA MA/MS № 220/14/03/79).

${ }^{4}$ Coordenadoria de Defesa Agropecuária - Escritório de defesa agropecuária de Registro. Eng. Agr, Gilmar Gilberto Alves, 2001. 
Além das informações sobre os principais agrotóxicos utilizados na região foram avaliados também, utilizando como indicadores os 12 parâmetros de agrotóxicos incluídos na Portaria de Potabilidade (Apêndice A), as informações sobre cada um destes agrotóxicos obtidas na literatura ("O Manual de Pesticidas", $20^{\circ}$ edição, e "Compêndio de Defensivos Agrícolas", 5ª edição). Concluiu-se que existe grande probabilidade de utilização nas culturas da região os pesticidas contendo os princípios ativos atrazina, 2,4-D, endosulfan, glifosato, metoxicloro, pendimetalina, simazina e trifluralina. Deste somente o glifosato (TAB.12) é citado no relatório do Escritório de Defesa Agropecuária de Registro - EDA/RE.

\subsubsection{Reconhecimento da área}

As várias visitas à área de estudo permitiram realizar uma prospecção sobre o uso e ocupação do solo, revelando evidências objetivas do impacto das atividades agropecuárias ao redor da bacia. $\mathrm{Na}$ TAB.13 são apresentadas as principais informações observadas sobre as áreas de captação estudada.

O reconhecimento da área possibilitou obter uma "fotografia" da região. No APÊNDICE C temos a representação fotográfica da área de estudo. Verificouse que a região, embora preservada, apresenta impactos ambientais, principalmente, causados pela agropecuária, tais como:

- Substituição da mata ciliar por plantação de banana ao longo das margens do rio Ribeira de Iguape.

- A ocupação de uma pequena ilha a montante da ETA de Eldorado, no Rio Ribeira de Iguape, para plantação de banana e um pequeno pasto para eqüinos (APÊNDICE $C$ fotos 1 e 2 ).

- Grandes áreas desmatadas, inclusive cumes de morro, para plantação de braquiária para o pasto bovino em área de proteção ambiental (APA), entre Iporanga e Barra do Turvo e as margens do rio Turvo (APÊNDICE $C$ fotos 17 e 18). A presença de queimada para o cultivo (APÊNDICE C foto 12). 
- Depósito de produtos agrícolas próximos as margens do rio Ribeira (APÊNDICE C fotos 4, 5 e 6).

- Pulverização aérea de agrotóxicos em áreas de plantação de banana próximo à cidade de Registro (APÊNDICE $\mathrm{C}$ foto 8 ).

- As fotos $11,12,14,15$ e 16 (APÊNDICE C) são registros de algumas ETAs e pontos de captação da SABESP.

- Área com plantação de hortaliças ao redor do ponto de captação de Registro, foto tirada em novembro de 2003 (APÊNDICE C foto 19). Na ocasião da primeira visita, em março de 2001, havia uma plantação de banana nessa área, indicando uma mudança nos insumos agrícolas utilizados e, portanto, uma mudança nas substâncias carreadas para o rio nos períodos de cheias. Atualmente, a área está abandonada, sem plantação e coberta por mato.

- Exploração de mineração de areia ao longo do rio Ribeira de Iguape (APÊNDICE C foto 20).

Tabela 13 - Caracterização da Área de Estudo: usos da água; ETAs , captações e observações relevantes quanto o uso e ocupação do solo Unidade do Vale do Ribeira - SABESP.

\begin{tabular}{|c|c|c|c|}
\hline $\begin{array}{l}\text { Município } \\
\text { Código } \\
\text { SABESP }\end{array}$ & $\begin{array}{l}\text { População } \\
\text { Total e } \\
\text { Urbana }^{1}\end{array}$ & $\begin{array}{l}\text { Informações sobre } \\
\text { Captação }^{(2)} \text { e ETA }{ }^{(3)} \text {, }\end{array}$ & $\begin{array}{l}\text { Observações de campo } \\
\qquad(2002 / 2004) \\
\text { e dados de literatura (*) }\end{array}$ \\
\hline Iporanga & 4.564 hab & $\begin{array}{l}\text { Captação: Rio Iporanga } \\
\text { ETA convencional, } 10 \text { Ls }^{-1} \\
\text { Início de Operação: } 1987\end{array}$ & $\begin{array}{l}\text { O rio Iporanga nasce em Apiaí e corre } \\
\text { em área de parque estadual, porém, } \\
\text { perto da nascente existem culturas de } \\
\text { tomate e pêssego. }\end{array}$ \\
\hline LR 068 & 2.076 hab & $\begin{array}{l}\text { Índice de atendimento atual: } \\
\text { Água de abastecimento - } \\
100 \% \\
\text { Coleta de esgoto - } 72 \% \\
\text { Tratamento de esgoto - } \\
100 \%\end{array}$ & $\begin{array}{l}\text { Próximo ao ponto de captação, a jusante } \\
\text { da área, devido ao fácil acesso, existe a } \\
\text { possibilidade de invasão da área. Isso } \\
\text { pode ser observado in'loco com a } \\
\text { presença de um caminhão de mudas, } \\
\text { dentro do rio, utilizando a água para } \\
\text { molhar as mudas. (foto-7, março 2002) - } \\
\text { APÉNDICE C. }\end{array}$ \\
\hline & & & - Cidade histórica fundada em 1576. \\
\hline
\end{tabular}


Tabela 13 - Caracterização da Área de Estudo: usos da água; ETAs , captações e observações relevantes quanto o uso e ocupação do solo Unidade do Vale do Ribeira - SABESP (continuação).

\begin{tabular}{|c|c|c|c|}
\hline $\begin{array}{l}\text { Município } \\
\text { Código } \\
\text { SABESP }\end{array}$ & $\begin{array}{c}\text { População } \\
\text { Total e } \\
\text { Urbana }^{1}\end{array}$ & $\begin{array}{l}\text { Informações sobre } \\
\text { Captação }^{(2)} \text { e ETA }{ }^{(3)}\end{array}$ & $\begin{array}{l}\text { Observações de campo } \\
\qquad(2002 / 2004) \\
\text { e dados de literatura }\left(^{*}\right)\end{array}$ \\
\hline Eldorado & 13.884 hab & $\begin{array}{l}\text { Captação: Rio Ribeira de } \\
\text { Iguape } \\
\text { ETA convencional, } 33 \text { Ls }^{-1} \\
\text { Início de Operação: Anterior } \\
\text { à } 1986 \\
\text { Índice de atendimento atual: } \\
\text { Água de abastecimento - } \\
100 \% \\
\text { Coleta de esgoto - } 80 \% \\
\text { Tratamento de esgoto - } \\
100 \%\end{array}$ & $\begin{array}{l}\text { A ETA apresenta sérios problemas de } \\
\text { enchentes nos períodos de chuva. } \\
\text { A montante do ponto de captação há } \\
\text { uma área de plantação com mais de } \\
100.000 \text { pés de banana. } \\
\text { O solo é muito rico em Fe e Mn. } \\
\text { Segundo informações dos técnicos da } \\
\text { ETA de Eldorado a pulverização aérea } \\
\text { com agrotóxicos ocorre nos bananais da } \\
\text { região sem respeitar os limites do rio. } \\
\text { Há aldeias de quilombolas na região. } \\
\text { A montante da captação existe uma llha } \\
\text { no centro do rio Ribeira onde metade de } \\
\text { sua área é utilizada como pasto para os } \\
\text { cavalos e outra metade para cultivo da } \\
\text { banana (fotos - } 1 \text { e } 2 \text { ) - APÊNDICE C. } \\
\text { A mineração de areia no leito do rio } \\
\text { provoca erosão das margens (foto - } 3 \text { ) - } \\
\text { Apêndice C. } \\
\text { No km } 98 \text { da estrada de Eldorado a } \\
\text { Iporanga registrou-se a existência de um } \\
\text { galpão, a poucos metros do rio em uma } \\
\text { área de plantação de banana, que } \\
\text { continha sacos de um produto granulado } \\
\text { que pode ser agrotóxico ou fertilizante. } \\
\text { Pouco antes do galpão havia manchas } \\
\text { azuis no solo, provavelmente, devido à } \\
\text { utilização do sulfato de cobre (fotos - } 4 \text {, } \\
5 \text { e } 6 \text { ) - APÊNDICE C. }\end{array}$ \\
\hline
\end{tabular}


Tabela 13 - Caracterização da Área de Estudo: usos da água; ETAs , captações e observações relevantes quanto o uso e ocupação do solo Unidade do Vale do Ribeira - SABESP (continuação).

\begin{tabular}{|c|c|c|c|}
\hline $\begin{array}{l}\text { Município } \\
\text { Código } \\
\text { SABESP }\end{array}$ & $\begin{array}{l}\text { População } \\
\text { Total e } \\
\text { Urbana }^{1}\end{array}$ & $\begin{array}{l}\text { Informações sobre } \\
\text { Captação }^{(2)} \text { e ETA }{ }^{(3)}\end{array}$ & $\begin{array}{l}\text { Observações de campo } \\
\qquad(2002 / 2004) \\
\text { e dados de literatura }\left(^{*}\right)\end{array}$ \\
\hline \multirow{3}{*}{$\begin{array}{l}\text { Sete } \\
\text { Barras }\end{array}$} & \multirow[t]{2}{*}{ 13.669 hab } & $\begin{array}{l}\text { Captação: Rio Ribeira de } \\
\text { lguape }\end{array}$ & $\begin{array}{l}\text { Área de cultivo de banana e Mineração } \\
\text { de areia }\end{array}$ \\
\hline & & $\begin{array}{l}\text { ETAs convencionais, } \\
1 \text { un. } 12 \text { Ls }^{-1}\end{array}$ & $\begin{array}{l}\text { Economia da cidade baseia-se na } \\
\text { produção de banana, piscicultura e } \\
\text { palmito pupunha (Infovale, 2004) }\end{array}$ \\
\hline & \multirow[t]{7}{*}{4.651 hab } & 1 un $25 \mathrm{Ls}^{-1}$ & \\
\hline \multirow[t]{6}{*}{$L R-005$} & & $\begin{array}{l}\text { Início de Operação: } 1994 \text { : } \\
\text { un. } 25 \mathrm{Ls}^{-1}\end{array}$ & \\
\hline & & Anterior à $1986:$ un $12 \mathrm{Ls}^{-1}$ & \\
\hline & & $\begin{array}{l}\text { Índice de atendimento } \\
\text { atual: }\end{array}$ & \\
\hline & & $\begin{array}{l}\text { Água de abastecimento - } \\
100 \%\end{array}$ & \\
\hline & & Coleta de esgoto $-81 \%$ & \\
\hline & & $\begin{array}{l}\text { Tratamento de esgoto - } \\
97 \%\end{array}$ & \\
\hline \multirow{2}{*}{ Juquiá } & \multirow{2}{*}{20.448 hab } & \multirow{4}{*}{$\begin{array}{l}\text { Captação: Rio Juquiá- } \\
\text { classe especial; } \\
\text { ETA convencional, } 27 \text { Ls }^{-1} \\
\text { Início de operação: anterior } \\
\text { a 1986; } \\
\text { Índice de atendimento } \\
\text { atual: }\end{array}$} & $\left({ }^{*}\right)$ Uso do solo: \\
\hline & & & $\begin{array}{l}\text { Agricultura: Banana-ordenada; } 37.000 \text { ha } \\
\text { zona rural com pequenos, médios e } \\
\text { grandes agricultores.; }\end{array}$ \\
\hline \multirow{7}{*}{ LR - 022} & \multirow{7}{*}{12.394 hab } & & Pecuária: gado, 9.000 cabeças de leite e \\
\hline & & & $\begin{array}{l}\text { corte e, } 6.000 \text { ha de pastagens. } \\
\text { Extração mineral: }\end{array}$ \\
\hline & & $\begin{array}{l}\text { Água de abastecimento - } \\
100 \%\end{array}$ & \multirow{2}{*}{$\begin{array}{l}\text { areia de rio- utilização de dragas } \\
\text { regularizadas mas sem controle; } 8 \\
\text { areeiros ativos e mineradodas- Rios } \\
\text { Juquiá e Assungi }\end{array}$} \\
\hline & & Coleta de esgoto $-64 \%$ & \\
\hline & & $\begin{array}{l}\text { Tratamento de esgoto - } \\
96 \%\end{array}$ & $\begin{array}{l}\text { A mineração de cascalho é ilegal, pois é } \\
\text { realizada por mineradoras embargadas } \\
\text { pelo IBAMA. }\end{array}$ \\
\hline & & & $\begin{array}{l}\text { brita - empreiteira, legal e fiscalizada. } \\
\text { BR } 116\end{array}$ \\
\hline & & & Lixão próximo bairro Ribeirãozinho. \\
\hline
\end{tabular}


Tabela 13 - Caracterização da Área de Estudo: usos da água; ETAs , captações e observações relevantes quanto o uso e ocupação do solo Unidade do Vale do Ribeira - SABESP (continuação).

\begin{tabular}{|c|c|c|}
\hline $\begin{array}{c}\text { Município } \\
\text { Código } \\
\text { SABESP }\end{array}$ & $\begin{array}{c}\text { População } \\
\text { Total e } \\
\text { Urbana }^{1}\end{array}$ & $\begin{array}{l}\text { Informações sobre } \\
\text { Captação }^{(2)} \text { e ETA }{ }^{(3)} \text {, }\end{array}$ \\
\hline \multirow[t]{2}{*}{ Registro } & 53.505 hab & $\begin{array}{l}\text { Captação: Rio Ribeira de } \\
\text { lguape }\end{array}$ \\
\hline & & $\begin{array}{l}\text { ETA convencional, } 188 \text { Ls }{ }^{-1} \\
\text { Início de Operação : } 1994\end{array}$ \\
\hline \multirow[t]{4}{*}{ LR - 001} & 42.853 hab & Índice de atendimento atual: \\
\hline & & $\begin{array}{l}\text { Água de abastecimento - } \\
100 \%\end{array}$ \\
\hline & & Coleta de esgoto $-71 \%$ \\
\hline & & $\begin{array}{l}\text { Tratamento de esgoto - } \\
98 \%\end{array}$ \\
\hline
\end{tabular}

\author{
Observações de campo \\ (2002/ 2004) \\ e dados de literatura $(*)$
}
Captação no rio Ribeira de Iguape fica na periferia da cidade. À margem direita do rio, entorno da captação, há uma grande área para a plantação que na primeira visita à região era uma plantação de banana, depois numa próxima visita (pouco mais de um ano) a mesma esta sendo usada para o cultivo de hortaliças e recentemente, constatou- se que a área não está sendo usada para agricultura. Indicando uma rotatividade no uso do solo.

Registro é o pólo metropolitano do Vale do Ribeira, embora, a cidade não possua a maior arrecadação. $O$ monitoramento de todas a ETA's da SABESP no Vale é feito na ETA de Registro

\begin{tabular}{|c|c|c|c|}
\hline Iguape & 26.052 hab & $\begin{array}{l}\text { Captação: Rio Ribeira de } \\
\text { lguape, }\end{array}$ & $\begin{array}{l}\text { O ponto de captação localiza-se próximo } \\
\text { ao estuario. }\end{array}$ \\
\hline \multirow{7}{*}{ LR 033} & \multirow{7}{*}{20.076 hab } & ETA convencional: & \multirow{2}{*}{$\begin{array}{l}\text { Ilha com mata nativa e área de } \\
\text { pastagem de búfalo. } \\
\left({ }^{*}\right) \text { Uso do solo: }\end{array}$} \\
\hline & & 1 un $104 \mathrm{Ls}^{-1}$ & \\
\hline & & \multirow{5}{*}{$\begin{array}{l}\text { Início de Operação: } \\
\text { 1978:1. un } 78 \text { Ls }^{-1} \\
\text { I998 com } 1 \text { un } 104 \text { Ls }^{-1}\end{array}$} & $\begin{array}{l}\text { Agricultura: Bananicultura- } 70 \% \text { área } \\
\text { cultivada }\end{array}$ \\
\hline & & & Subsistência e regime de meia. Com: \\
\hline & & & $\begin{array}{l}\text { 1.700ha para plantio; e } 2.170 \\
\text { trabalhadores sindicalizados }\end{array}$ \\
\hline & & & $\begin{array}{l}\text { Pecuária: boi de corte e leite, bufalo, } \\
9.500 \text { cabeças bolvinos; } 2.200 \text { cabeças } \\
\text { de bubalino; } 80.000 \text { litros de leite / ano; } \\
5.500 \text { ha pastagens. }\end{array}$ \\
\hline & & & $\begin{array}{l}\text { Grandes produtores e pequemos } \\
\text { proprietários. }\end{array}$ \\
\hline
\end{tabular}


Tabela 13 - Caracterização da Área de Estudo: usos da água; ETAs , captações e observações relevantes quanto o uso e ocupação do solo Unidade do Vale do Ribeira - SABESP (continuação).

\begin{tabular}{|c|c|c|c|}
\hline $\begin{array}{l}\text { Município } \\
\text { Código } \\
\text { SABESP }\end{array}$ & $\begin{array}{l}\text { População } \\
\text { Total e } \\
\text { Urbana }^{1}\end{array}$ & $\begin{array}{l}\text { Informações sobre } \\
\text { Captação }^{(2)} \text { e ETA }{ }^{(3)}\end{array}$ & $\begin{array}{l}\text { Observações de campo } \\
\qquad(2002 / 2004) \\
\text { e dados de literatura (*) }\end{array}$ \\
\hline \multirow{3}{*}{$\begin{array}{l}\text { Barra do } \\
\text { Turvo }\end{array}$} & \multirow[t]{2}{*}{8.107 hab } & & \multirow{8}{*}{$\begin{array}{l}\text { A captação fica na divisa com o Estado } \\
\text { do Paraná. } \\
\text { No trecho entre Iporanga e Barra do } \\
\text { Turvo, ao longo do rio Turvo, embora } \\
\text { seja uma área de Reserva, observou-se } \\
\text { uma vasta área de desmatamento com } \\
\text { plantação de baquearia como pasto para } \\
\text { gado. }\end{array}$} \\
\hline & & $\begin{array}{l}\text { Córrego do Chopim - } \\
\text { Classe } 2\end{array}$ & \\
\hline & \multirow[t]{6}{*}{2.879 hab } & ETA convencional: $16 \mathrm{Ls}^{-1}$ & \\
\hline \multirow[t]{5}{*}{ LR - 142} & & $\begin{array}{l}\text { Início de operação: } 1994 \text { no } \\
\text { rio Pardo e anterior a } 1986 \\
\text { o córrego Chopim; }\end{array}$ & \\
\hline & & Índice de atendimento: & \\
\hline & & $\begin{array}{l}\text { Água de abastecimento - } \\
100 \%\end{array}$ & \\
\hline & & Coleta de esgoto $-64 \%$ & \\
\hline & & Tratamento de esgoto $94 \%$ & \\
\hline \multirow[t]{8}{*}{ Cajati } & \multirow[t]{3}{*}{29.018 hab } & $\begin{array}{l}\text { Captação: rio } \\
\text { Jacupiranguinha }\end{array}$ & $\begin{array}{l}\text { Maior receita da agropecuária } \\
(\mathrm{R} \$ 41.172,00) \text { da microrregião de }\end{array}$ \\
\hline & & ETA convencional, $80 \mathrm{Ls}^{-1}$ & \\
\hline & & Início de operação: 1998; & $\begin{array}{l}\text { Exploração de fosfato e calcário pela } \\
\text { Serrana S/A. }\end{array}$ \\
\hline & \multirow[t]{5}{*}{20.934 hab } & $\begin{array}{l}\text { Índice de atendimento atual: } \\
\text { Água de abastecimento - }\end{array}$ & $\begin{array}{l}\text { A indústria é a principal atividade } \\
\text { econômica do município. }\end{array}$ \\
\hline & & $100 \%$ & \multirow{3}{*}{$\begin{array}{l}\text { As terras em Cajati são muito férteis. A } \\
\text { lavoura de banana ocupa } 5320 \text { hectares } \\
\text { de terra com a produção anual de } \\
162500 \text { toneladas. Em } 18 \text { hectares são } \\
\text { colhidas } 9000 \text { caixas de maracujá. } \\
\text { Mexerica, } 50000 \text { caixas. São produzidas } \\
480 \text { toneladas de chá, além de outras } \\
\text { culturas. }\end{array}$} \\
\hline & & Coleta de esgoto $-71 \%$ & \\
\hline & & Tratamento de esgoto $-0 \%$ & \\
\hline & & & $\begin{array}{l}\text { A pecuária com } 6000 \text { hectares de pasto } \\
\text { natural e } 3600 \text { de pasto cultivado cria } \\
5000 \text { cabeças de gado de corte e de } 100 \\
\text { de gado leiteiro (Cajati, 2004). }\end{array}$ \\
\hline
\end{tabular}


Tabela 13 - Caracterização da Área de Estudo: usos da água; ETAs , captações e observações relevantes quanto o uso e ocupação do solo Unidade do Vale do Ribeira - SABESP (continuação).

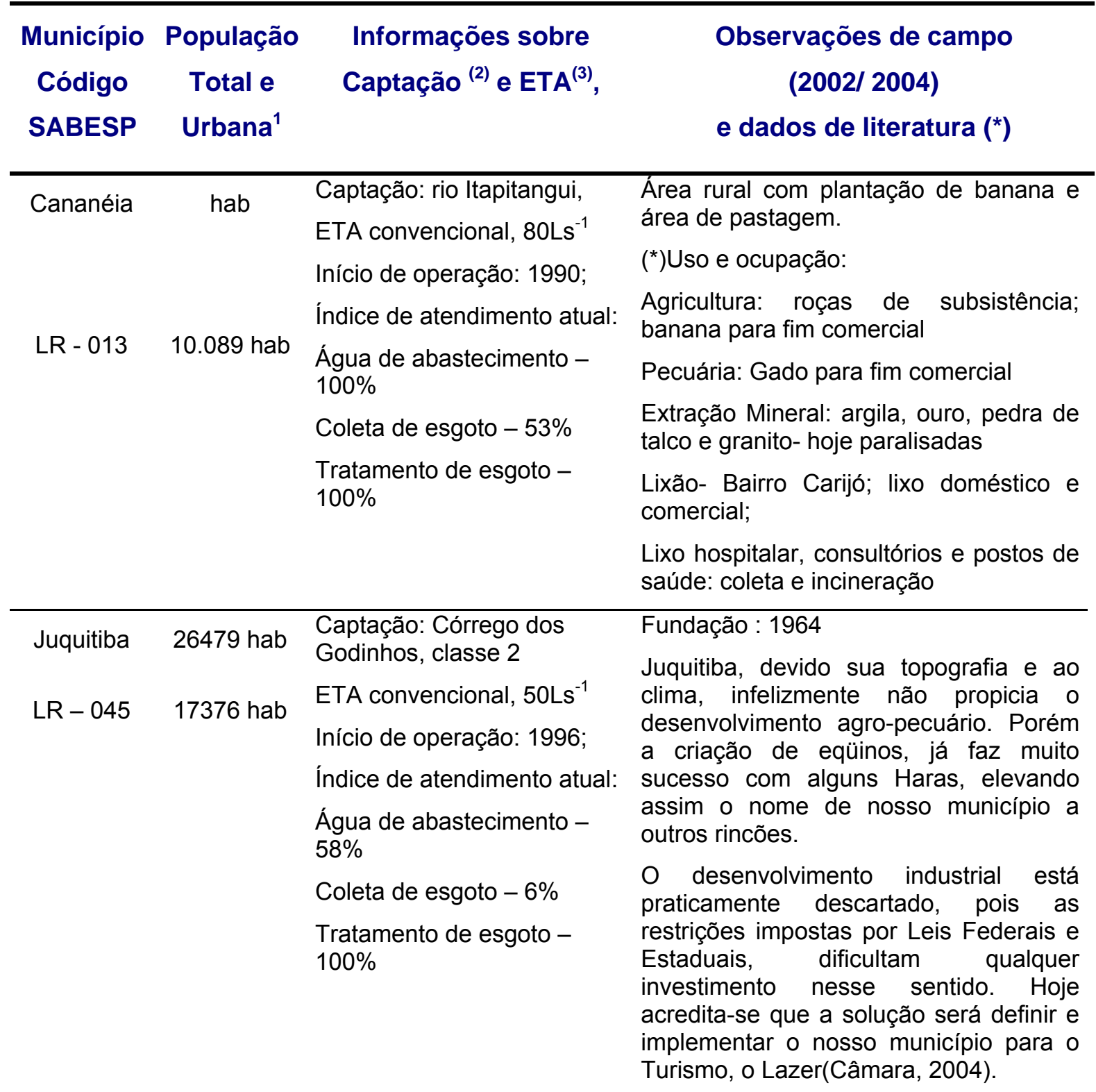

Fonte: SABESP- Unidade de Negócio Vale do Ribeira, Junho, 2001; CETESB, 2002.

(1) IBGE, 2000, 1997

(2) Classe 2: Rio Ribeira de Iguape; Rio Juquiá; Rio Pardo, Córrego Chopim; Rio Jacupiranguinha

(3) ETA Convencional: Tratamento-Floculação, decantação, filtração, cloração e fluoretação (Informações : Setor de Controle Sanitário LR C1- Unidade de Negócio do Vale do Ribeira - LR Registro/ SP, 2002).

(*) Uso do solo: IBAMA, SMA,UNICAMP, 1998.Diagnóstico ambiental participativo do Vale do Ribeira e Litoral Sul de São Paulo. 
A região, embora, preservada já mostra impactos visuais da ocupação antrópica, principalmente, no setor agropecuário. A FAO (Food and Agriculture Organization) adverte que operações agrícolas podem contribuir para degradação da qualidade da água através da liberação de diversos materiais para os corpos d’água, como: solo, sedimentos, agrotóxicos, esterco animal, adubos e outros materiais orgânicos e inorgânicos. Muitos destes poluentes alcançam os recursos superficiais e subterrâneos através das enxurradas (runoff) e percolação no solo e são chamados de fontes de poluição difusas. A identificação, quantificação e controle de fontes difusas são tarefas relativamente mais difíceis de se realizar quando comparada às fontes pontuais (FAO, 1996; Katsuóka, 2001).

\subsubsection{Avaliação dos parâmetros físico-químicos da qualidade da água bruta}

Nas FIG.17, 1819 e 20 são apresentados os comportamentos espaçotemporal dos parâmetros físico-químicos da água ao longo Bacia, no período de 1996-2000 referentes aos municípios de Juquiá, Eldorado, Iguape, Registro, Sete Barras e Iporanga (banco de dados fornecido pelo Laboratório de Controle Sanitário da SABESP de Registro).

Aplicou-se a estatística descritiva, obtendo-se as médias mensais dos parâmetros físico-químicos: $\mathrm{pH}$, cor, turbidez e alcalinidade da água bruta com os quais construiram-se os gráficos para todo o período. Estes dados possibilitaram traçar um perfil das características físico-químicas da água da bacia e verificar que os parâmetros cor e turbidez são elevados e apresentam um comportamento sazonal (FIG.17, 18, 19 e 20). Portanto, foram estabelecidas coletas sazonais, sendo, quatro coletas no período de cheia (outubro a março) e duas coletas no período de seca (abril a setembro), sem perder a representatividade amostral. 


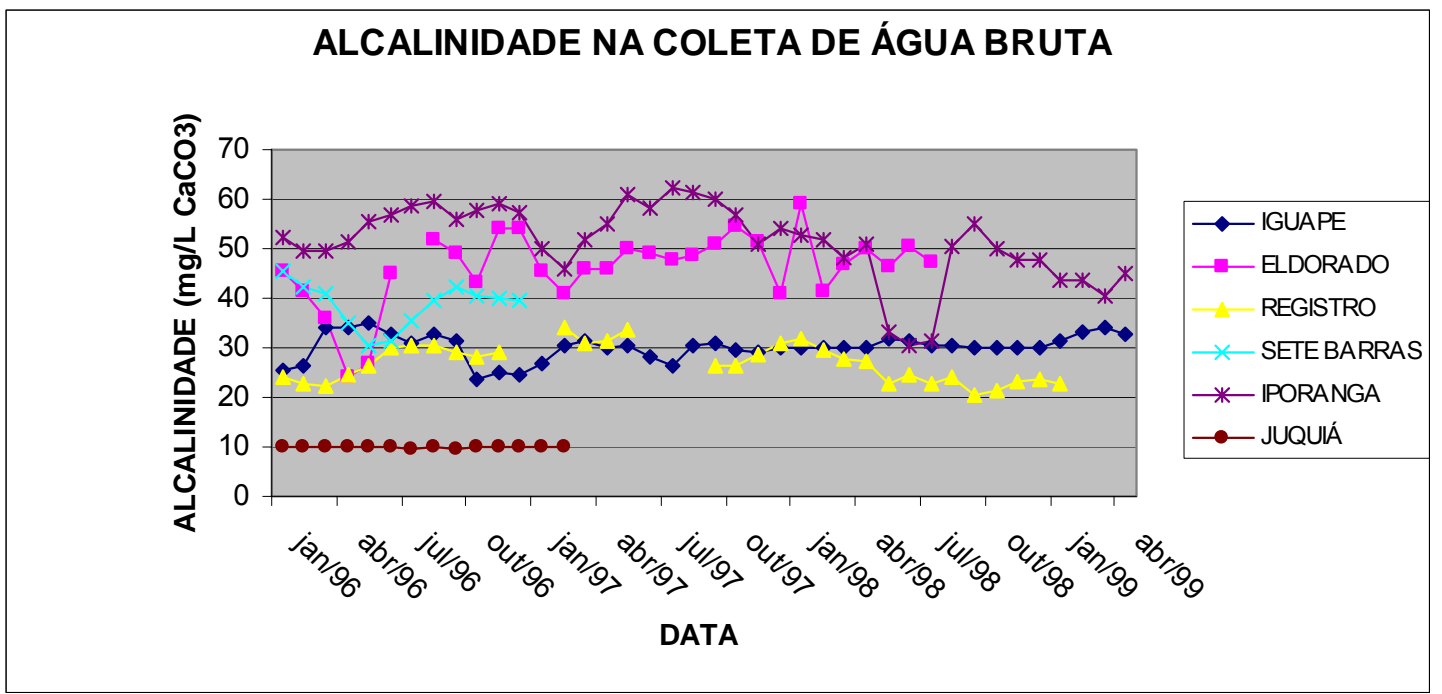

FIGURA 17 - Variação da alcalinidade da água superficial no período de Janeiro/96 a Abril/99, nas ETAs de Iguape, Eldorado, Registro, Sete Barras, Iporanga e Juquiá.

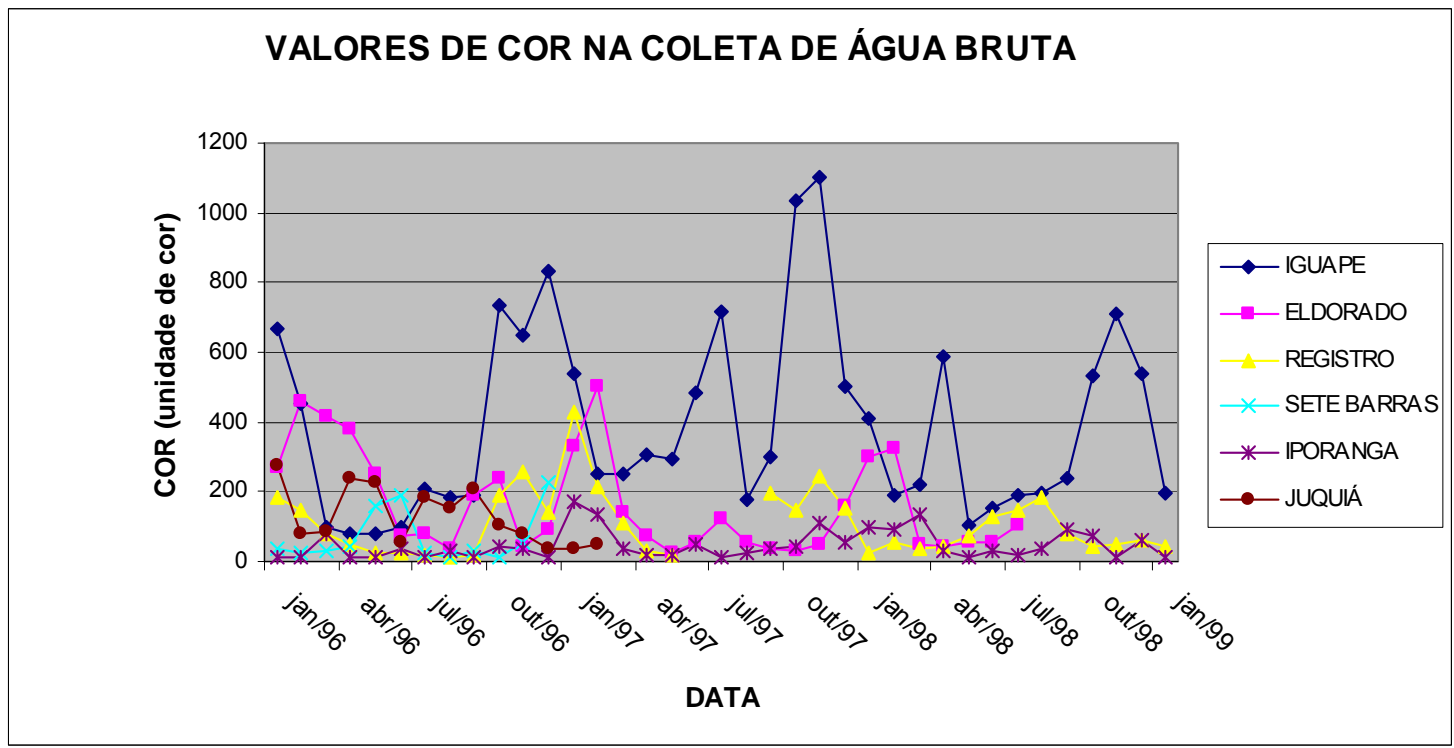

FIGURA 18 - Variação da cor da água superficial no período de Jan/96 a Jan/99, nas ETAs de Iguape, Eldorado, Registro, Sete Barras, Iporanga e Juquiá. 


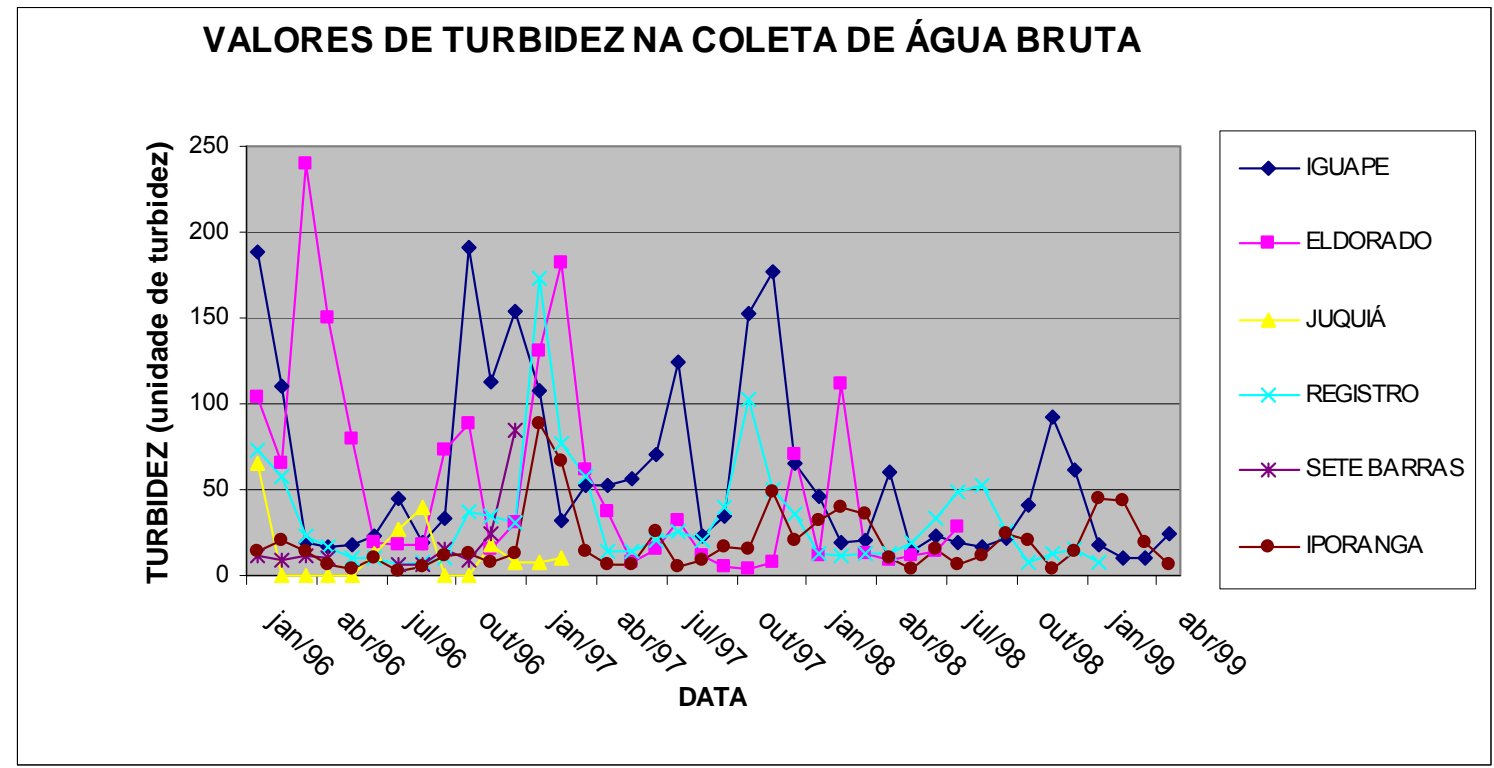

FIGURA 19 - Variação da turbidez da água superficial no período de Jan/96 a mar/99, nas ETAs de Iguape, Eldorado, Registro, Sete Barras, Iporanga e Juquiá.

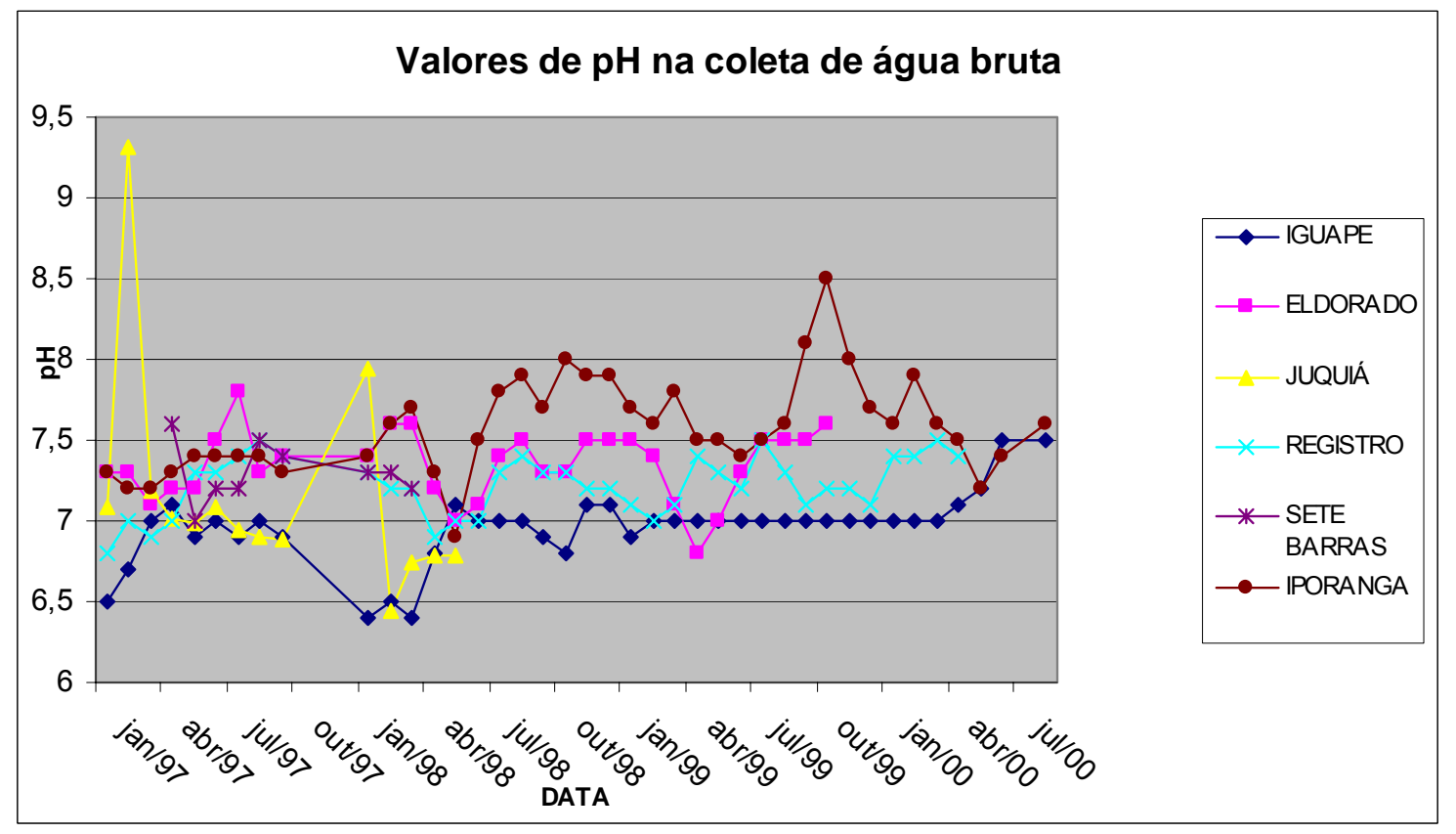

FIGURA 20 - Variação da pH da água superficial no período de Jan/97a Jul/00, nas ETAs de Iguape, Eldorado, Registro, Sete Barras, Iporanga e Juquiá. 
Analisando os gráficos se observa que a alcalinidade e $\mathrm{o} \mathrm{pH}$ não apresentam um comportamento sazonal. A alcalinidade do rio Juquiá (ETA Juquiá), praticamente, é constante além de apresentar um valor, relativamente, baixo $\left(10 \mathrm{mgL}^{-1}\right.$ de $\left.\mathrm{CaCO}_{3}\right)$. O rio Ribeira de Iguape apresenta uma variação maior na faixa de 20 a $55 \mathrm{mgL}^{-1}$ de $\mathrm{CaCO}_{3}$ (ETAs - Eldorado, Sete Barras, Registro e Iguape). As amostras de água da captação da ETA de Iporanga, no rio Iporanga, apresentram maior alcalinidade na faixa de 40 a $60 \mathrm{mgL}^{-1}$ de $\mathrm{CaCO}_{3}$. Quanto ao pH o rio Juquiá apresentou maior variação no período avaliado, com uma média de $\mathrm{pH}$ alta para o mês de fevereiro de 97 , já o rio Ribeira de Iguape variou em média na faixa de $\mathrm{pH} 7$ a 7,5 em todo o período. O rio Iporanga apresentou valores de $\mathrm{pH}$ maiores, na faixa 7,3 a 8 .

Quanto aos parâmetros cor e turbidez estas apresentaram um perfil sazonal com médias mais altas nos períodos de cheia e médias mais baixas no período de seca. Os rios Juquiá e Iporanga apresentaram médias mais baixas tanto para turbidez como para cor. O rio Ribeira de Iguape apresentou médias mais altas, principalmente, nos períodos de cheia. A ETA de lguape apresentou as maiores médias, provavelmente, por receber a contribuição de toda a bacia.

\subsubsection{Avaliação da temperatura e precipitação}

A água destinada ao abastecimento público na região é captada em três diferentes compartimentos: manancial superficial, manancial subterrânea e manancial de serra. Neste trabalho foram estudados os pontos de captação superficial, portanto, com maior probabilidade de sofrer contaminações provenientes de atividades antrópicas e variações da intempérie.

No período de chuvas, geralmente, ocorre um aumento da concentração de matéria orgânica dissolvida e de material particulado que são carreados para os corpos d'água. A decomposição microbiana dessa matéria orgânica consome grande parte do oxigênio dissolvido, aumentando o grau de desoxigenação da água, com conseqüências danosas sobre o metabolismo do sistema aquático (Esteves, 1988). Em períodos de seca, normalmente são verificadas baixas concentrações de substâncias nos corpos d'água. Essa baixa 
concentração pode ser justificada pela ausência de escoamento superficial proveniente das águas de chuvas (“runnoff”) (Katsuóka, 2001).

A região situa-se no limite entre clima tropical e subtropical, ainda sob influência dos ventos do sudeste. Estes ventos sopram constantemente do sudeste rumo ao Equador, têm sua origem na forte queda de pressão atmosférica entre o centro de alta pressão (anticiclone) subtropical do atlântico sul entre latitudes $20^{\circ}$ e $30^{\circ}$ e o centro de baixa pressão (ciclone) equatorial. Típica dessa região costeira é a intensidade pluviométrica, além da distribuição diferenciada das chuvas (SMA,1992).

A região litorânea da UGRHI 11 (estação de Iguape) apresenta características climáticas com temperatura média anual de $21,5^{\circ} \mathrm{C}$, precipitação normal anual de cerca de $1.900 \mathrm{~mm}$ e unidade relativa do ar de aproximadamente $70 \%$.

Chove em média cerca de $1.400 \mathrm{~mm}^{\mathrm{ano}}{ }^{-1}$, sendo que na sub-bacia de Juquiá com $1.500 \mathrm{~mm} \mathrm{ano}^{-1}$ chove mais que na sub-bacia do Ribeira de Iguape, abrangendo as áreas de drenagens à jusante de Registro. O período mais chuvoso vai de setembro a março, sendo janeiro o mês de maior pluviosidade. Entre os meses de abril e agosto, período de seca, a precipitação média fica ao redor de $50 \mathrm{~mm}$, sendo o mês de agosto o menos chuvoso.

Nas FIG.21 e 22 são apresentados os diagramas climáticos com as médias mensais de chuva e temperatura, no período de 2000 a 2003, medidos nas oito estações meteorológicas da bacia do rio Ribeira de Iguape. Os dados foram obtidos no Centro Integrado e Informações agrometeorológicos (CIIAGRO). Estas se localizam nos municípios de: Cananéia, Eldorado, Jacupiranga (duas estações), Miracatu, Pariquera - Açu, Registro e Sete Barras. O diagrama da FIG.23 apresenta as médias mensais de chuva e temperatura da região como um todo e foi construído com as médias das oito estações. 
Cananéia - Precipitação média anual = $1876 \mathrm{~mm}$ - (2000 - 2003)

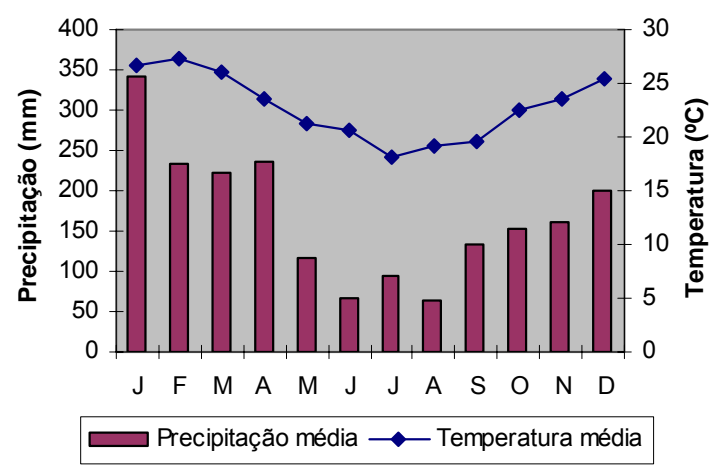

Jacupiranga - Precipitação média anual $=1658 \mathrm{~mm}-(2000-2003)$

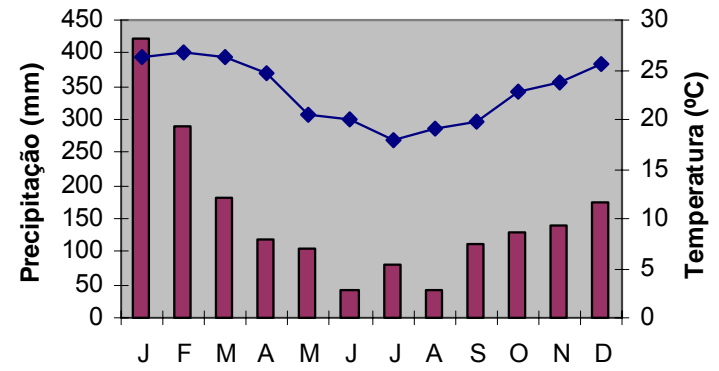

Precipitação $\multimap$ Temperatura
Eldorado - Precipitação média anual = $1175 \mathrm{~mm}$ - (2000-03)

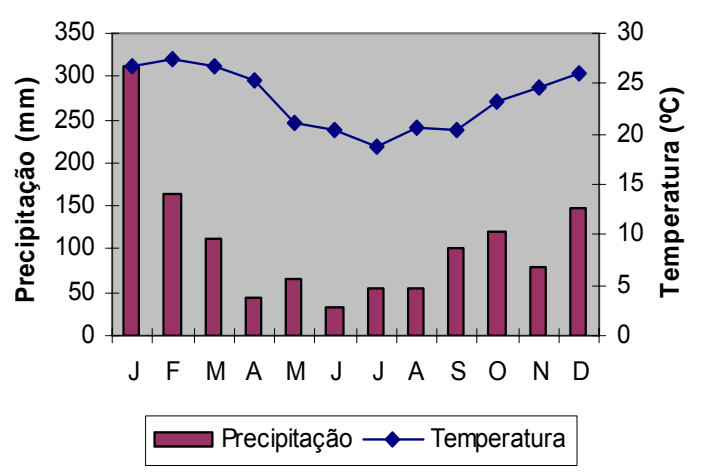

Jacupiranga CA - Precipitação média anual $=1385 \mathrm{~mm}-(2000-2003)$

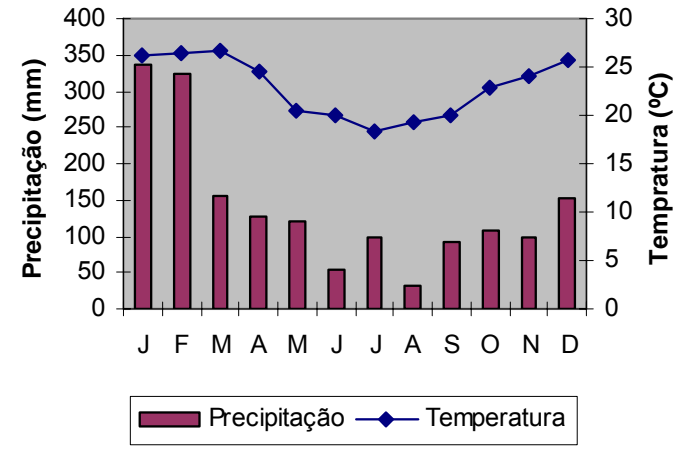

FIGURA 21 - Diagramas climáticos das Estações Meteorológicas de Cananéia, Eldorado, Jacupiranga e Jacupiranga-CA, da UGRH Ribeira de Iguape e Litoral Sul no período de 2000 a 2003. (CIAGRO, 2003; adaptado por Marques, M.N.) 

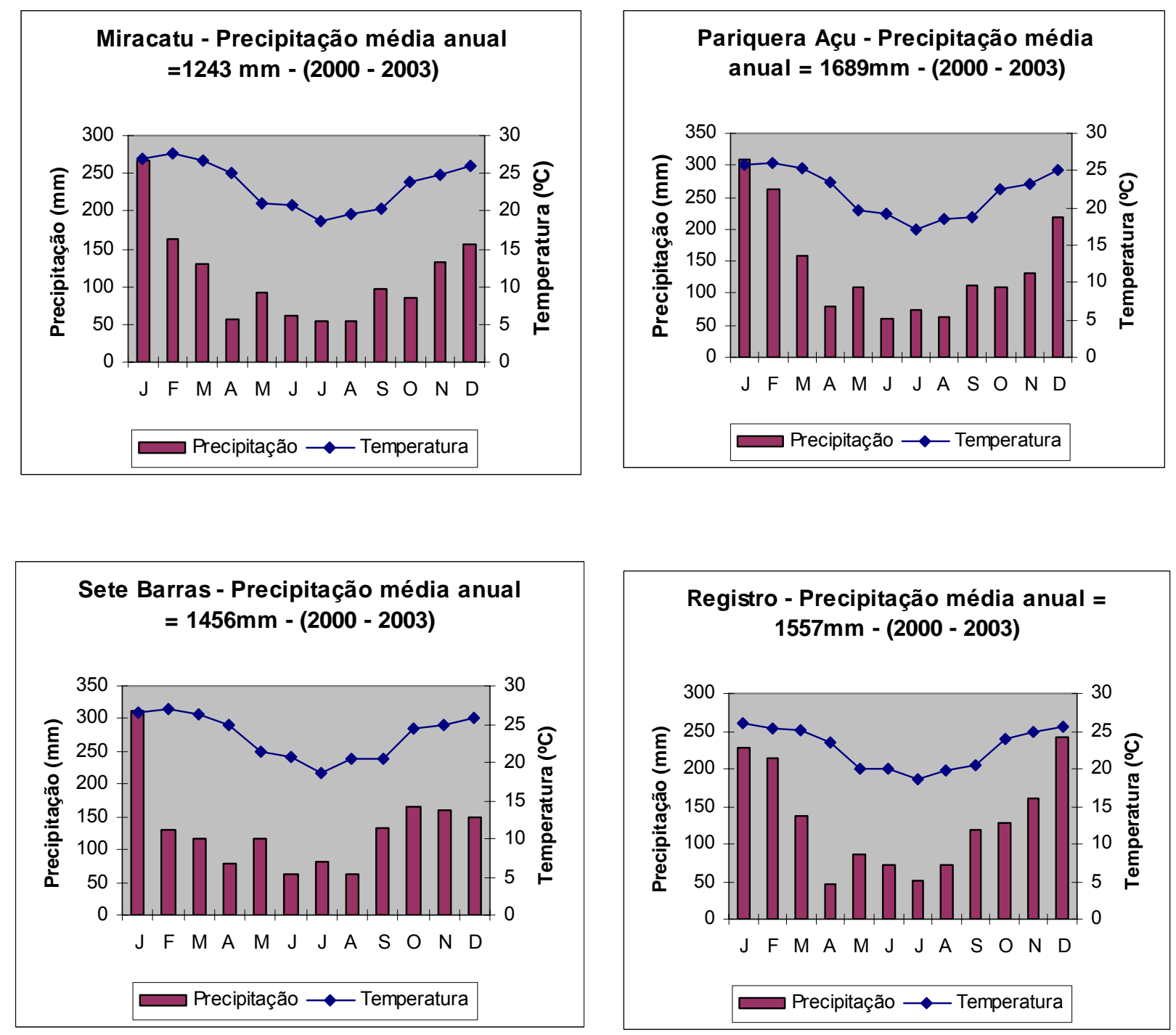

FIGURA 22 - Diagramas climáticos das Estações Meteorológicas de Miracatu, Pariquera-Açu, Sete Barras e Registro, da UGRH Ribeira de Iguape e Litoral Sul no período de 2000 a 2003. (CIAGRO, 2003; adaptado por Marques, M.N.)

O clima da região não é homogêneo devido a fatores locais como a presença das serras, vegetação e proximidade do mar, principalmente, em relação à precipitação que apresenta um valor anual médio de $1876 \mathrm{~mm}$ para os dados obtidos na estação meteorológica de Cananéia e $1175 \mathrm{~mm}$ e $1243 \mathrm{~mm}$ para as estações de Eldorado e Miracatu, respectivamente. 
UGRH do Ribeira de Iguape e Litoral Sul - Precipitação média anual = 1758mm - (2000-2003)

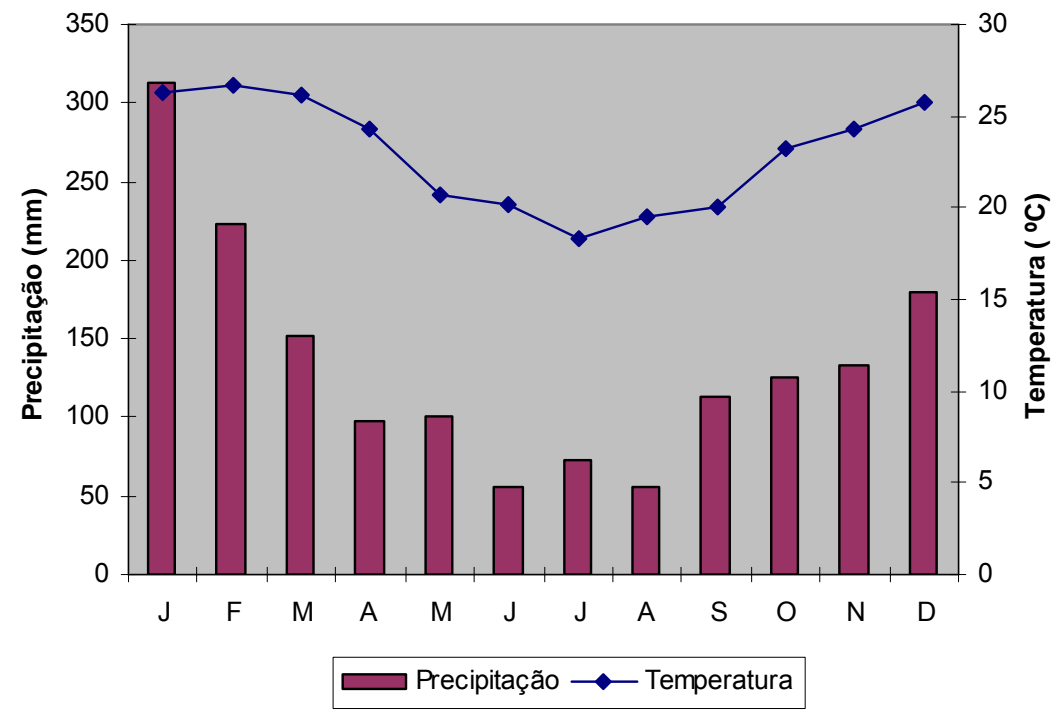

FIGURA 23 - Diagrama climático da UGRH Ribeira de Iguape e Litoral Sul no no período de 2000 a 2003. (CIAGRO, 2003; adaptado por Marques, M.N.)

Durante o período de coleta as estações meteorológicas de Jacupiranga e Cananéia registraram médias acima de $600 \mathrm{~mm}$ no mês de janeiro de 2003. Pode-se observar que a região de uma maneira geral apresenta uma temperatura média de $23,2^{\circ} \mathrm{C}$ que oscilam entre $28^{\circ} \mathrm{C}$ e $18^{\circ} \mathrm{C}$ e precipitação anual média de 1758mm (FIG.23). 


\subsection{Avaliação do potencial de lixiviação e percolação dos agrotóxicos como análise de risco}

O objetivo desse estudo foi realizar uma análise do risco potencial de contaminação por agrotóxicos em águas superficiais e subterrâneas, principalmente herbicidas, aplicando critérios desenvolvidos pela EPA e literatura básica (Cohen et al., 1995; Goss, 1992; Dores \& Freire, 2001; Rao \& Hornsby, 2003; Bicki, 2004).

A SABESP na Unidade de Negócios Vale do Ribeira/Litoral Sul abastece 18 municípios e 48 comunidades isoladas e tem como pontos de captação 48 sistemas produtores, dos quais 17 são de água superficial, 17 são poços e 10 são de mananciais de serra (água de classe especial) bem protegidas, permitindo um tratamento mais simples como a cloração e fluoretação, diferenciado das ETAs que utilizam sistema de tratamento convencional (Pires, 2004; SABESP, 2004). Segundo o relatório de situação dos recursos hídricos da bacia hidrográfica do Ribeira de Iguape (CETEC, 2002) os aqüíferos da região são sedimentares e cristalinos.

\subsubsection{Análise de risco}

Para se fazer uma análise preliminar do risco potencial de contaminação das águas superficiais e subterrâneas, seria ideal que se fizesse um estudo das características dos solos da região estudada. Mas isto tornaria o trabalho extremamente oneroso além de não corresponder ao foco principal do nosso estudo. Portanto, as avaliações foram focadas somente nas propriedades físico-químicas dos princípios ativos dos agrotóxicos mais usados na região e nas informações de solos obtidas no mapa geomorfológico do Estado de São Paulo (IPT, 1997), FIG.10.

As propriedades físico-químicas dos princípios ativos dos produtos comerciais aplicados na Região e os demais agrotóxicos estudados neste trabalho, são apresentadas na TAB.14. As propriedades físico-químicas dos agrotóxicos usados como critérios de avaliação de seu potencial de risco para 
ambientes aquáticos foram: constantes da Lei de Henry $\left(\mathrm{K}_{H}\right)$, solubilidade em água, coeficiente de partição octanol - água Kow, coeficiente de adsorção à matéria orgânica do solo Koc, meia-vida (DT ${ }_{50}$ ) no solo e na água. Analisando-se as informações contidas na Tabela 21 pode-se observar que estas propriedades diferem grandemente entre os diversos compostos de classes químicas diferentes ou de mesma classe química, tornado extremamente difícil a tarefa de fazer generalizações sobre os destinos e impactos de agrotóxicos no ambiente.

O comportamento de agrotóxicos no ambiente deve ser diferente entre as condições de climas temperado e tropical, mas existem poucos estudos sobre agrotóxicos em ambientes tropicais, portanto, optou-se por usar os dados publicados na literatura para ambientes temperados, de modo que fosse possível uma comparação entre eles (Dores \& Freire, 2001).

Quanto à toxicidade aguda, a maioria dos agrotóxicos aplicados na região (TAB.12, pág.77) são considerados de medianamente a pouco tóxicos (classe III e IV). Somente os inseticidas Furadan Líquido e Counter $50 \mathrm{G}$ são extremamente tóxicos (classe I) e o Servin, Gramoxone e Gramoxil são altamente tóxicos (classe II). Onde, os critérios de classificação toxicológica são apresentados na TAB.4 (pág.33).

\subsubsection{Risco de contaminação de águas subterrâneas}

Na TAB.15 são apresentados os resultados da análise do potencial de contaminação de águas subterrâneas usando os critérios de "screening" propostos pela EPA. Foram consideradas as propriedades apresentadas na TAB.14 para analisar o risco dos agrotóxicos usados na região atingirem águas subterrâneas. Conforme se pode observar alguns dados não foram encontrados na literatura consultada. Alguns dos princípios ativos podem ser classificados como compostos que apresentam maior probabilidade de atingir as águas subterrâneas, pois têm elevada solubilidade em água, baixa adsorção à matéria orgânica do solo e meia-vida no solo relativamente alta. 
TABELA 14 - Propriedades físico-químicas, a $20-25^{\circ} \mathrm{C}$, dos princípios ativos dos agrotóxicos usados na região da Bacia do Rio Ribeira e os avaliados neste trabalho.

\begin{tabular}{|c|c|c|c|c|c|c|c|c|c|}
\hline Classe & Princípio Ativo & $\begin{array}{l}\text { Pressão de } \\
\text { Vapor (atm) }\end{array}$ & $\begin{array}{c}\text { Solubilidade } \\
\text { em água } \\
\left(\mathrm{mgL}^{-1}\right)\end{array}$ & $\operatorname{Kow}_{\text {Kow }}$ & $\begin{array}{c}\mathrm{Koc} \\
\left(\mathrm{cm}^{3} \mathrm{~g}^{-1}\right)^{(2)}\end{array}$ & $\begin{array}{c}\mathrm{DT}_{50}{ }^{(3)} \\
\text { no solo } \\
\text { (dias) }\end{array}$ & $\begin{array}{c}\mathrm{DT}_{50} \text { hidrólise } \\
\text { (dias) }\end{array}$ & $\begin{array}{c}\mathrm{K}_{\mathrm{H}}^{(4)} \\
\left(\operatorname{atm} \cdot \mathrm{m}^{3} \cdot \mathrm{mol}^{-1}\right)\end{array}$ & GUS $^{5}$ \\
\hline \multirow{4}{*}{$\begin{array}{l}\frac{\pi}{0} \\
\frac{0}{0} \\
\frac{5}{5} \\
\frac{1}{4}\end{array}$} & Propiconazole & $1,3 \times 10^{-9}$ & $100-110$ & 3,5 & 1.900 & $40-70$ & $25-85$ & $4,1 \times 10^{-9}$ & 1,33 \\
\hline & Terbuconazole & $1,3 \times 10^{-11}$ & $36\left(20^{\circ} \mathrm{C}\right)$ & 3,7 & --- & --- & --- & $1,45 \times 10^{-10}$ & --- \\
\hline & Benzimidazoles & $1,0 \times 10^{-7}$ & $\begin{array}{c}2,01 \times 10^{3} \\
\left(30^{\circ} \mathrm{C}\right)\end{array}$ & 1,32 & 110 & --- & --- & $3,7 \times 10^{-7}$ & --- \\
\hline & Azoxistrobina & $1,1 \times 10^{-15}$ & 6 & 2,5 & 550 & 4015 & -- & $6,91 \times 10^{-14}$ & 4,54 \\
\hline \multirow{4}{*}{ 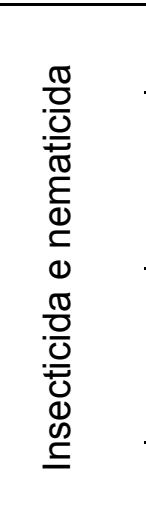 } & Aldicarbe & $1,3 \times 10^{-7}$ & $4,93 \times 10^{3}$ & 1,13 & 100 & $1-15$ & $62-433$ & $4,9 \times 10^{-9}$ & 2,35 \\
\hline & Carbofurano & $\begin{array}{c}3,1 \times 10^{-10}- \\
7.1 \times 10^{-10}\end{array}$ & 320 & 2,32 & 22 & $30-60$ & $\begin{array}{c}>365(\mathrm{pH} \mathrm{4}) \\
121(\mathrm{pH} 7) \mathrm{e} \\
31(\mathrm{pH} \mathrm{9})\end{array}$ & $4,4 \times 10^{-9}$ & 4,52 \\
\hline & Carbaril & $5,3 \times 10^{-8}$ & 120 & 2,36 & 300 & 10 & $\begin{array}{c}12(\mathrm{pH} 7) \\
3,2 \mathrm{~h}(\mathrm{pH} \mathrm{9})\end{array}$ & $8,8 \times 10^{-8}$ & 1,52 \\
\hline & Terbufós & $4,2 \times 10^{-7}$ & 15 (ppm) & 3,68 & 2,400 & 5 & 3.5 & $2,4 \times 10^{-5}$ & 0,43 \\
\hline & $\begin{array}{l}{ }^{(1)} \mathrm{Kow}=\text { coeficier } \\
{ }^{(4)} \mathrm{K}_{\mathrm{H}}=\text { constante } \\
\text { Obs.: Os dados } \mathrm{f} \\
\text { Tomlin (1994). }\end{array}$ & $\begin{array}{l}\text { le partição octa } \\
\text { lei de Henry; } \\
\text { n obtidos nas }\end{array}$ & $\begin{array}{l}\text { Dlágua; }{ }^{(2)} \mathrm{Koc} \\
\text { US calculado } \\
\text { yuintes publica }\end{array}$ & $\begin{array}{l}\text { coeficien } \\
\text { ndice de } \\
\text { es: TOXN }\end{array}$ & $\begin{array}{l}\text { de adsorçãc } \\
\text { Inerabilidad } \\
\text { T (2004); Rc }\end{array}$ & $\begin{array}{l}\text { matéria } \\
\text { la água } s \\
\text { igues e } A\end{array}$ & $\begin{array}{l}\text { ânica; }{ }^{(3)} \text { DT50 = } \\
\text { terrânea). } \\
\text { eida (1998); Dor }\end{array}$ & $\begin{array}{l}\text { neia-vida; } \\
\text { \& Freire, 2001; }\end{array}$ & \\
\hline
\end{tabular}


TABELA 14 - Propriedades físico-químicas, a $20-25^{\circ} \mathrm{C}$, dos princípios ativos dos agrotóxicos usados na região da Bacia do Rio Ribeira e os avaliados neste trabalho (continuação).

\begin{tabular}{|c|c|c|c|c|c|c|c|c|c|}
\hline Classe & Princípio Ativo & $\begin{array}{l}\text { Pressão de } \\
\text { Vapor (atm) }\end{array}$ & $\begin{array}{l}\text { Solubilidade } \\
\text { em água } \\
\left(\mathrm{mgL}^{-1}\right)\end{array}$ & $\log \underset{(1)}{K o w}$ & $\begin{array}{c}\mathrm{Koc} \\
\left(\mathrm{cm}^{3} \mathrm{~g}^{-1}\right)^{(2)}\end{array}$ & $\begin{array}{c}\mathrm{DT}_{50}{ }^{(3)} \\
\text { no solo } \\
\text { (dias) }\end{array}$ & $\begin{array}{c}\mathrm{DT}_{50} \text { hidrólise } \\
\text { (dias) }\end{array}$ & $\begin{array}{c}\mathrm{K}_{\mathrm{H}^{(4)}} \\
\left(\mathrm{atm} \cdot \mathrm{m}^{3} \cdot \mathrm{mol}^{-1}\right)\end{array}$ & GUS $^{5}$ \\
\hline \multirow{8}{*}{$\begin{array}{l}\frac{n}{\pi} \\
\frac{\pi}{0} \\
: \frac{0}{0} \\
\frac{0}{2} \\
\end{array}$} & Paraquate & $<1,3 \times 10^{-8}$ & solúvel & 4,22 & $\begin{array}{c}15.473- \\
1.000 .000\end{array}$ & 1,000 & --- & $1 \times 10^{-9}$ & 0,57 \\
\hline & Diuron & $9,1 \times 10^{-11}$ & 36,4 & 2,68 & $224-879$ & 330 & --- & $5,8 \times 10^{-10}$ & $\begin{array}{c}2,66- \\
4,15\end{array}$ \\
\hline & Glifosato & desprezível & 12.000 & $0,17 \times 10^{-2}$ & 24.000 & $45-60$ & --- & --- & 0,64 \\
\hline & Glufosinato & $1.2 \times 10^{-14}$ & 1370 & $\begin{array}{l}<0,1 \\
(\mathrm{pH} 7)\end{array}$ & $9,6-1.229$ & $6-20$ & $>300$ & $4,4 \times 10^{-14}$ & $\begin{array}{c}2,35- \\
5,09\end{array}$ \\
\hline & Sulfosato & --- & --- & --- & --- & --- & --- & --- & --- \\
\hline & Atrazina & $3,85 \times 10^{-7}$ & 33 & 2,5 & 124 & 50 & $105-200$ & $2,86 \times 10^{-9}$ & 3,24 \\
\hline & Simazina & $2,9 \times 10^{-11}$ & 6,2 & 2,1 & 115 & 59 & --- & $3,36 \times 10^{-9}$ & 3,43 \\
\hline & Trifluralina & $9,38 \times 10^{-10}$ & 0,221 & 5,2 & 6417 & 170 & --- & $3,97 \times 10^{-7}$ & 0,43 \\
\hline
\end{tabular}

(1)Kow = coeficiente de partição octanol/água; ${ }^{(2)}$ Koc = coeficiente de adsorção à matéria orgânica; ${ }^{(3)}$ DT50 = meia-vida;

(4) $\mathrm{K}_{\mathrm{H}}=$ constante da lei de Henry; ${ }^{(5)}$ GUS calculados (Índice de vulnerabilidade da água subterrânea).

Obs.: Os dados foram obtidos nas seguintes publicações: TOXNET (2004); Rodrigues e Almeida (1998); Dores \& Freire, 2001; Tomlin (1994). 
TABELA 15 - Resultados da avaliação de risco de contaminação de águas subterrâneas com base nos critérios de "screening" estabelecido pela EPA e no índice de vulnerabilidade da água subterrânea (GUS).

\begin{tabular}{|c|c|c|c|c|c|c|c|c|}
\hline $\begin{array}{c}\text { Classe } \\
\text { agrotóxico }\end{array}$ & Princípio Ativo & Solub. & Koc & $\begin{array}{l}{ }^{1} \mathrm{DT}_{50} \\
\text { soil }\end{array}$ & $\begin{array}{l}\mathrm{DT}_{50} \\
\text { hidr. }\end{array}$ & ${ }^{2} K_{H}$ & GUS & Risco \\
\hline \multirow{4}{*}{ Fungicida } & Propiconazole & $\odot$ & (:) & ๑ & (;) & (:) & baixo & IN \\
\hline & Terbuconazole & $\odot$ & & & & (:) & & I \\
\hline & Benzimidazoles & $\odot$ & $\odot$ & & & (:) & & $\mathrm{CP}$ \\
\hline & Azoxistrobina & (:) & (:) & $\odot$ & & $\odot$ & alto & $\mathrm{CP}$ \\
\hline \multirow{4}{*}{$\begin{array}{l}\text { Inseticida e } \\
\text { nematicida }\end{array}$} & Aldicarbe & $\odot$ & $\odot$ & () & $\odot$ & ;) & moderado & $\mathrm{CP}$ \\
\hline & Carbofurano & $\odot$ & $\odot$ & $\odot$ & (-) & ;) & alto & $\mathrm{CP}$ \\
\hline & Carbaril & $\odot$ & ๑ & ;) & (;) & (:) & médio & IN \\
\hline & Terbufós & (:) & (:) & (:) & & $\odot$ & baixo & $\mathrm{NC}$ \\
\hline \multirow{8}{*}{ Herbicida } & Paraquate & ๑ & (:) & $\odot$ & & () & baixo & IN \\
\hline & Diuron & ๑ & $\odot$ & $\odot$ & & $\odot$ & médio a alto & $\mathrm{CP}$ \\
\hline & Glifosato & 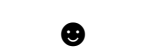 & (-) & () & & & baixo & IN \\
\hline & Glufosinato & 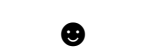 & 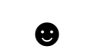 & () & 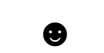 & $\Theta$ & médio a alto & $\mathrm{CP}$ \\
\hline & Sulfosate & & & & & & & I \\
\hline & Atrazina & 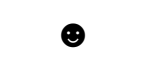 & $\odot$ & $\odot$ & $\odot$ & $\odot$ & alto & $\mathrm{CP}$ \\
\hline & Simazina & (;) & $\odot$ & $\odot$ & & (-) & alto & $\mathrm{CP}$ \\
\hline & Trifluralina & (;) & (;) & & & (;) & baixo & $\mathrm{NC}$ \\
\hline
\end{tabular}

Obs: ๑) - não atende ao critério; $\odot$ - atende ao critério como potencial perigoso; CP contaminante em potencial; NC - não contaminante; IN - intermediário; I - inconclusivo; em branco -dado não disponível na literatura consultada; ${ }^{1} \mathrm{DT}_{50}$ - meia-vida; ${ }^{2} \mathrm{~K}_{\mathrm{H}}-$ Constante da lei de Henry

Foram considerados contaminantes em potencial aqueles princípios ativos para os quais a maioria das propriedades físico-químicas disponíveis 
indicava uma possibilidade de contaminação de águas subterrâneas, com as seguintes considerações:

- Embora a solubilidade e o coeficiente de adsorção à matéria orgânica do solo (Koc) do azoxistrobina não atendam aos critérios de "screening" estabelecidos pela EPA, o índice de vulnerabilidade (GUS) obtido foi alto devido a meia-vida no solo ser extremamente alta (11 anos), colocando-o sob suspeita de contaminação de água subterrânea.

- O Koc e a solubilidade do diuron está no limite determinado, mostrando uma capacidade de ser altamente adsorvido mas, devido às outras características e citações na literatura este foi colocado sob suspeita de contaminação.

- . glifosato apesar de apresentar um índice de vulnerabilidade (GUS) baixo, por adsorver fortemente ao solo, poderá contaminar águas subterrâneas quando as características do solo não favorecerem a adsorção.

No caso do terbuconazole e sulfosate, para os quais não foram encontradas informações na literatura consultada, os resultados foram apresentados como inconclusivos.

Os compostos classificados na faixa de transição e de lixiviação provável, de acordo com o índice de vulnerabilidade (GUS), necessitam de uma investigação adicional usando métodos mais detalhados. Compostos classificados como improváveis de sofrerem lixiviação podem, seguramente, ser considerados como não contaminantes de águas subterrâneas (Cohen et al., 1995; Bicki, 2004).

Considerando esta afirmação e os critérios da EPA (TAB.15) pode-se dizer que o terbufós e trifluralina não são contaminantes em potencial para água subterrânea. Ficando em estágio intermediário o propiconazole, carbaril, paraquate e glifosato, necessitando assim para estes compostos estudos de monitoramento e controle de qualidade da água. Os compostos benzimidazoles, azoxistrobina, aldicarbe, carbofurano, paraquate, diuron, glifosato, atrazina e 
simazima foram classificados como possíveis contaminantes de águas subterrâneas, segundo suas características físico-químicas. Dentre esse a atrazina, simazina, carbofurano e diuron já foram detectados em águas subterrâneas, segundo a literatura consultada (Quintana et al, 2001; Hernández et al, 2001; Albanis et al, 1998; Dean et al, 1996; Kolpin et al, 2000).

\subsubsection{Risco de contaminação de águas superficiais}

Para a avaliação de risco de contaminação da água superficial por agrotóxico, utilizaram-se os critérios aplicados no método de avaliação do potencial de contaminação de águas superficiais desenvolvido por Goss (1992), TAB.16. Os agrotóxicos foram divididos entre os que podem ser transportados dissolvidos em água e aqueles que são transportados associados ao sedimento em suspensão.

A classificação, segundo os critérios de Goss, para os agrotóxicos em estudo são apresentados na TAB.16. Dentre aqueles com alto potencial de transporte associado ao sedimento estão: propiconazole, paraquate, glifosato, atrazina, simazina e trifluralina.

Os agrotóxicos que apresentaram maior capacidade de mobilidade disperso em água são: propiconazole, benzimidazoles, azoxistrobina, aldicarbe, carbofurano, paraquate, diuron e glifosato, sendo que destes o benzimidazoles, azoxistrobina, aldicarbe, carbofurano e diuron também são contaminantes em potencial de água subterrâneas.

Dos agrotóxicos estudados e mais utilizados na região o carbofurano é o composto com maior potencial de contaminação de água superficial devido à elevada meia-vida em água. Vale ressaltar que sua presença foi confirmada no decorrer do desenvolvimento deste trabalho (Marques et al, 2003).

Os fatores que podem contribuir para a contaminação dos agrotóxicos acima estudados, na região, são: o alto índice pluviométrico (1758mm por ano), 
os aqüíferos não confinados e, no Médio e Baixo Ribeira, a predominância solos com textura predominantemente arenosa com boa permeabilidade da água.

TABELA 16 - Classificação dos princípios ativos usados na região e dos demais compostos avaliados neste trabalho, de acordo com o seu potencial de contaminação de águas superficiais.

\begin{tabular}{|c|c|c|c|}
\hline $\begin{array}{c}\text { Classe } \\
\text { agrotóxico }\end{array}$ & Princípio Ativo & $\begin{array}{c}\text { Potencial de } \\
\text { transporte associado } \\
\text { ao sedimento }\end{array}$ & $\begin{array}{l}\text { Potencial de } \\
\text { transporte } \\
\text { dissolvido em } \\
\text { água }\end{array}$ \\
\hline \multirow{4}{*}{ Fungicida } & Propiconazole & $\bar{A}$ & $A$ \\
\hline & Terbuconazole & $\mathrm{I}$ & $\mathrm{I}$ \\
\hline & Benzimidazoles & $B$ & $A$ \\
\hline & Azoxistrobina & $\mathrm{M}$ & $\bar{A}$ \\
\hline \multirow{4}{*}{$\begin{array}{l}\text { Inseticida e } \\
\text { nematicida }\end{array}$} & Aldicarbe & B & $A$ \\
\hline & Carbofurano & $B$ & $A$ \\
\hline & Carbaril & $B$ & $M$ \\
\hline & Terbufós & $\mathrm{M}$ & $B$ \\
\hline \multirow{8}{*}{ Herbicida } & Paraquate & $A$ & $A$ \\
\hline & Diuron & $\mathrm{M}$ & $A$ \\
\hline & Glifosato & $A$ & $A$ \\
\hline & Glufosinato & $B$ & $\mathrm{M}$ \\
\hline & Sulfosate & $\mathrm{I}$ & $\mathrm{I}$ \\
\hline & Atrazina & A & $\mathrm{M}$ \\
\hline & Simazina & $A$ & $M$ \\
\hline & Trifluralina & $A$ & $\mathrm{M}$ \\
\hline
\end{tabular}

A - Alto; $\mathrm{B}$ - baixo; $\mathrm{M}$ - médio e I - inconclusivo

A análise dos dados apresentados permite afirmar que entre os agrotóxicos mais usados na agricultura da região, quase todos apresentam mobilidade no meio ambiente com exceção do terbufós que apresenta somente o potencial de transporte associado ao sedimento médio devido ao $\mathrm{Koc}$ alto ( $\mathrm{Koc}=$ $2.400 \mathrm{~cm}^{3} \mathrm{~g}^{-1}$ ) e os compostos terbuconazole e sulfosate que foram inconclusivos por não terem dados disponíveis na literatura consultada. 


\subsection{Otimização da metodologia para a análise multi-resíduos de carbamatos, triazinas e nitroanilinas utilizando LC - UVIVisível}

Os perfís dos cromatogramas obtidos no estudo de otimização de metodologia para análise multi-resíduo dos agrotóxicos aldicarbe, carbofurano, carbaril, atrazina e trifluralina utilizando a técnica de LC-UV/vis são apresentados nas FIG.24, 25 e 26. Todos cromatogramas foram obtidos nas condições analíticas apresentadas na TAB.17.

TABELA 17 - Programação do gradiente de eluição utilizando como fase móvel água (A) e acetonitrila (B)

\begin{tabular}{cccc}
\hline Tempo (min) & \% A & \% B & Curva \\
\hline 0 & 52 & 48 & ---- \\
\hline 4,5 & 52 & 48 & ---- \\
\hline 20,0 & 20 & 80 & Convexa* $^{\star}$ \\
\hline 21,0 & 20 & 80 & ---- \\
\hline
\end{tabular}

As condições de operação do sistema foram:

Fluxo da fase móvel: 1,0 $\mathrm{mLmin}^{-1}$; $\quad$ Pressão: $96 \mathrm{kgfcm}^{-2}$;

Volume de injeção: $20 \mu \mathrm{L} ; \quad$ Detecção no ultravioleta: 220 ๆm.

${ }^{*}$ Curva de gradiente não linear, convexa inclinação de -8.

$\mathrm{Na}$ FIG.24 é apresentado o cromatograma de uma amostra representando uma solução padrão contendo $0,20 \mathrm{mgL}^{-1}$ de cada princípio ativo estudado.

Na FIG.25 são apresentados dois cromatogramas; sendo um de uma amostra de água superficial, referente ao ponto de captação da ETA de Eldorado e o outro cromatograma da mesma amostra na qual foi realizada uma adição de uma amostra padrão contendo todos os princípios ativos estudados (amostra "spike").

Na FIG.26 são apresentados cromatogramas; de uma amostra de água tratada, amostra coletada na ETA de Iguape e da mesma amostra na qual foi realizada também a adição de padrão (amostra "spike"). 


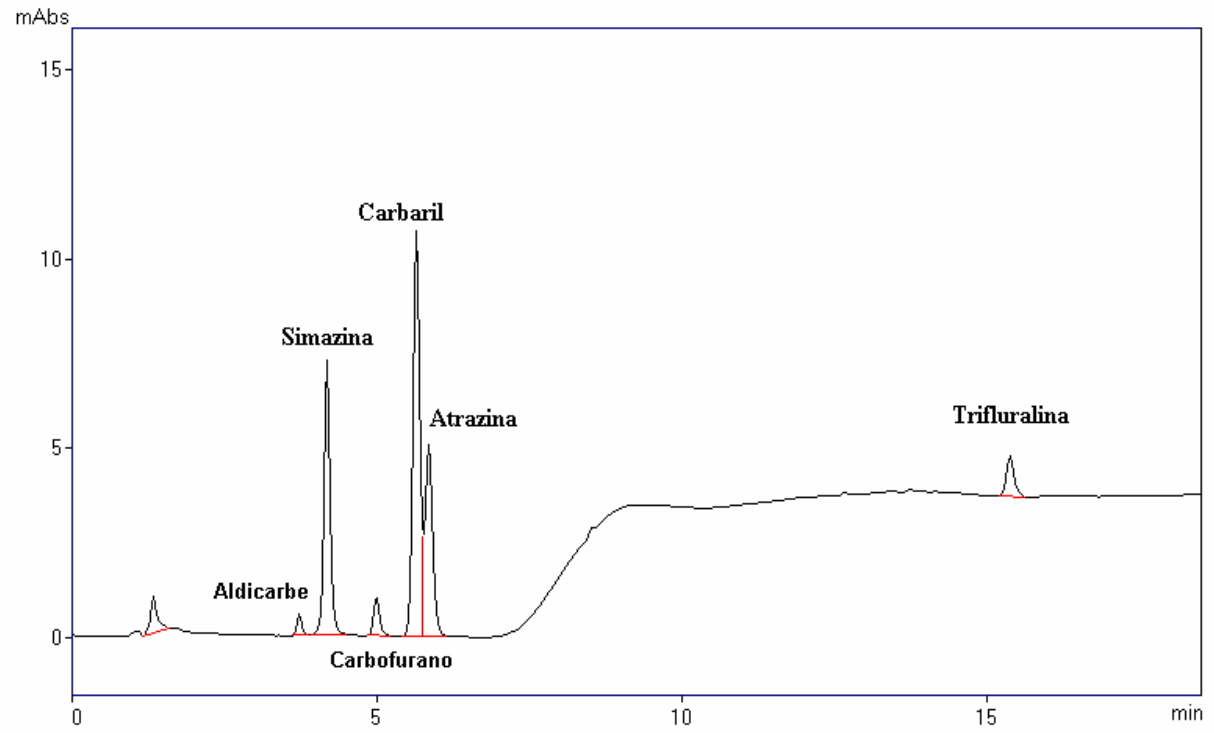

FIGURA 24 - Cromatograma de uma amostra padrão, concentração de cada composto: 0,20 mgL-1 (massa injetada = $4 \mathrm{mg}$ ).

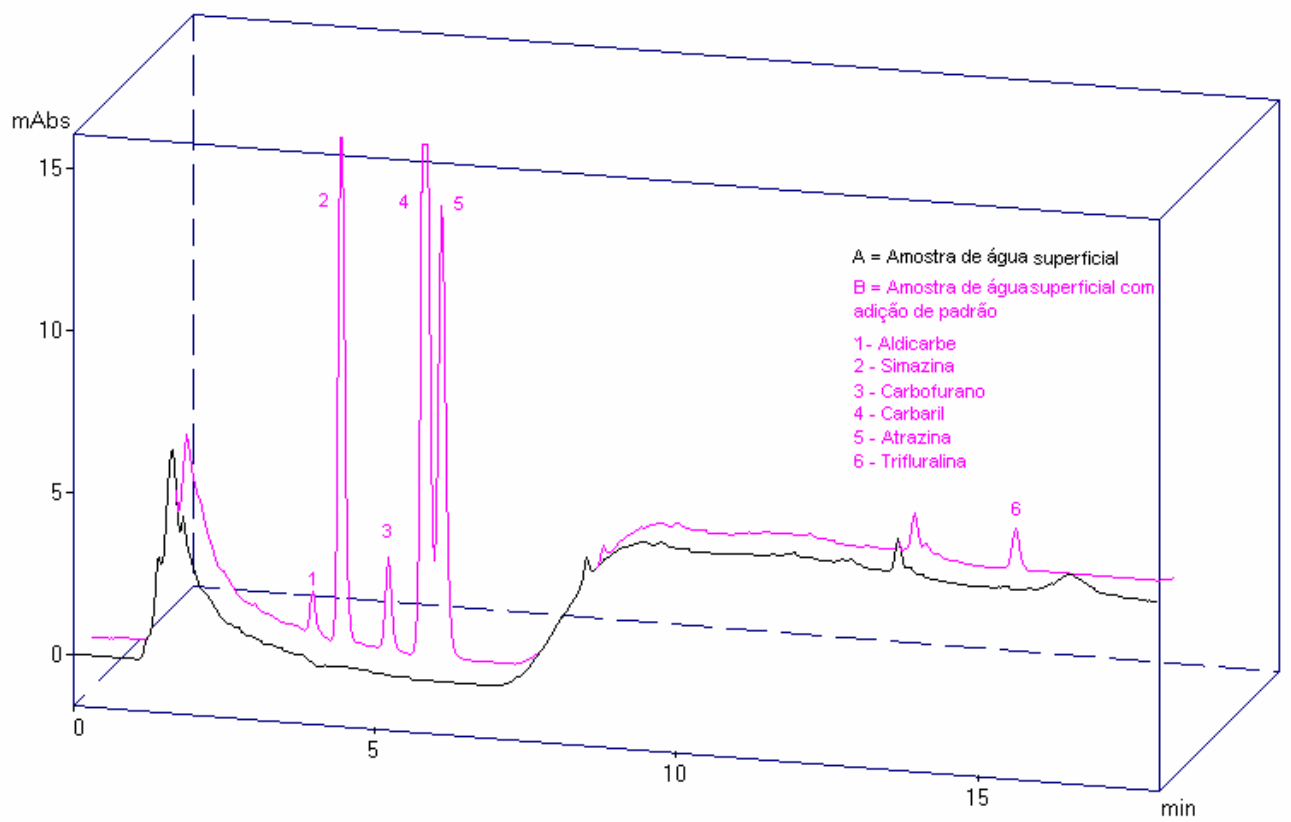

FIGURA 25 - Cromatogramas de uma amostra de água superficial (Rio Ribeira de Iguape, ponto de captação de Eldorado) e da amostra com adição de padrão, na concentração de $1,0 \mathrm{mgL}^{-1}$ de cada composto. 


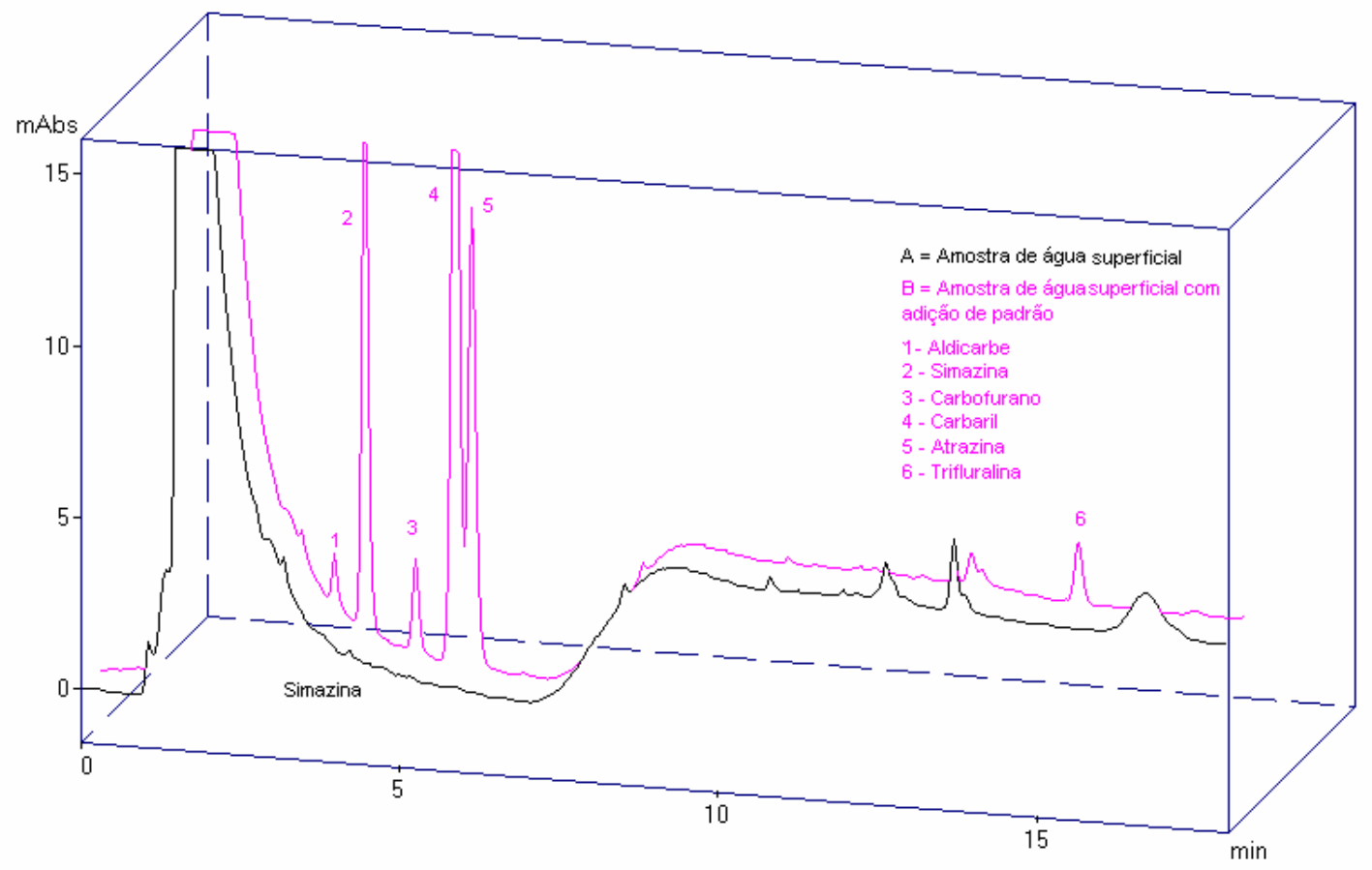

FIGURA 26 - Cromatogramas de uma amostra de água tratada, proveniente da ETA de Iguape, e da amostra com adição de padrão, na concentração de $1,0 \mathrm{mgL}^{-1}$ de cada composto

\subsubsection{Limite de detecção (LD) e limite de quantificação (LQ)}

Determinou-se o limite de detecção (LD) e quantificação (LQ) com a utilização da medida do sinal e do ruído, injetando-se soluções-padrão em triplicata, cujas concentrações são apresentadas na TAB.18.

Medindo-se a altura dos ruídos e dos picos, relativo à concentração dos compostos, obteve-se a média destes para calcular o LD e LQ, conforme as Equações 1 e 2, a seguir:

$$
\begin{array}{ll}
L D=C \times \frac{3}{S / R} & \text { Equação 1 } \\
L Q=C \times \frac{10}{S / R} & \text { Equação 2 }
\end{array}
$$


onde,

$C=$ concentração do composto

$S=$ sinais obtidos (uAbs)

$\mathrm{R}=$ ruído (uAbs)

3 = a razão S/R mínima para um pico ser detectado com segurança

10 = a razão S/R mínima para um pico ser quantificado com segurança

Todos o parâmetros utilizados para os cálculos do LD e LQ, os valores obtidos com o desvio padrão e os valores obtidos anteriormente por Lebre (2000), para comparação são apresentados na TAB.18.

TABELA 18 - Parâmetros utilizados para os cálculos do LD e LQ.

\begin{tabular}{|c|c|c|c|c|c|c|c|c|c|c|}
\hline Composto & $c^{a}$ & $\begin{array}{c}\mathrm{S} \\
(\mathrm{cm})\end{array}$ & $\begin{array}{c}\mathrm{R} \\
(\mathrm{cm})\end{array}$ & $F=S / R$ & LD & $L D \pm d p^{a}$ & LQ & $L Q \pm d p^{a}$ & $\begin{array}{c}\text { LD }^{\mathrm{a}} \\
\text { *antigo }\end{array}$ & $\begin{array}{c}\mathrm{LQ}^{\mathrm{a}} \\
\text { *antigo }\end{array}$ \\
\hline \multirow{3}{*}{ Aldicarbe } & \multirow{3}{*}{0,010} & $\overline{1,950}$ & 0,300 & 6,500 & 0,005 & \multirow{3}{*}{$\begin{array}{c}0,006 \pm \\
0,002\end{array}$} & 0,016 & \multirow{3}{*}{$\begin{array}{c}0,021 \pm \\
0,006\end{array}$} & \multirow{3}{*}{0,011} & \multirow{3}{*}{0,035} \\
\hline & & 1,900 & 0,350 & 5,429 & 0,006 & & 0,019 & & & \\
\hline & & 1,500 & 0,400 & 3,750 & 0,008 & & 0,028 & & & \\
\hline \multirow{3}{*}{ Atrazina } & \multirow{3}{*}{0,003} & 2,600 & 0,300 & 8,667 & 0,001 & \multirow{3}{*}{$\begin{array}{c}0,002 \pm \\
0,000\end{array}$} & 0,003 & \multirow{3}{*}{$\begin{array}{c}0,003 \pm \\
0,000\end{array}$} & \multirow{3}{*}{0,001} & \multirow{3}{*}{0,003} \\
\hline & & 2,400 & 0,300 & 8,000 & 0,001 & & 0,003 & & & \\
\hline & & 2,300 & 0,300 & 7,667 & 0,001 & & 0,003 & & & \\
\hline \multirow{3}{*}{ Carbaril } & \multirow{3}{*}{0,001} & 1,500 & 0,300 & 5,000 & 0,0006 & \multirow{3}{*}{$\begin{array}{c}0,0005 \pm \\
0,0001\end{array}$} & 0,002 & \multirow{3}{*}{$\begin{array}{c}0,002 \pm \\
0,001\end{array}$} & \multirow{3}{*}{0,001} & \multirow{3}{*}{0,002} \\
\hline & & 1,500 & 0,350 & 4,286 & 0,0007 & & 0,002 & & & \\
\hline & & 3,000 & 0,300 & 10,000 & 0,0003 & & 0,001 & & & \\
\hline \multirow{3}{*}{ Carbofurano } & \multirow{3}{*}{0,010} & 2,000 & 0,300 & 6,667 & 0,005 & \multirow{3}{*}{$\begin{array}{c}0,004 \pm \\
0,001\end{array}$} & 0,016 & \multirow{3}{*}{$\begin{array}{c}0,015 \pm \\
0,002\end{array}$} & \multirow{3}{*}{0,005} & \multirow{3}{*}{0,015} \\
\hline & & $\overline{1,950}$ & 0,250 & 7,800 & 0,004 & & 0,013 & & & \\
\hline & & 1,950 & 0,300 & 6,500 & 0,005 & & 0,016 & & & \\
\hline \multirow{3}{*}{ Simazina } & \multirow{3}{*}{0,001} & 4,000 & 0,400 & 10,000 & 0,0003 & \multirow{3}{*}{$\begin{array}{c}0,0003 \pm \\
0,0000\end{array}$} & 0,001 & \multirow{3}{*}{$\begin{array}{c}0,001 \pm \\
0,000\end{array}$} & \multirow{3}{*}{0,001} & \multirow{3}{*}{0,003} \\
\hline & & 4,050 & 0,350 & 11,571 & 0,0003 & & $\overline{0,001}$ & & & \\
\hline & & 4,150 & 0,400 & 10,375 & 0,0003 & & $\overline{0,001}$ & & & \\
\hline \multirow{3}{*}{ Trifluralina } & & 2,750 & 0,300 & 9,167 & 0,0034 & \multirow{3}{*}{$\begin{array}{c}0,004 \pm \\
0,001\end{array}$} & 0,011 & \multirow{3}{*}{$\begin{array}{c}0,013 \pm \\
0,002\end{array}$} & \multirow{3}{*}{0,010} & \\
\hline & 0,0102 & 2,500 & 0,400 & 6,250 & 0,0049 & & 0,016 & & & 0,035 \\
\hline & & 3,050 & 0,350 & 8.714 & 0.0035 & & $\overline{0.012}$ & & & \\
\hline
\end{tabular}

${ }^{\mathrm{a}}$ Todas as concentrações estão em $\mu \mathrm{gmL}^{-1}$

$\left(^{*}\right)$ LEBRE, 2000 
Analisando-se os valores obtidos para detecção e quantificação dos compostos atrazina, carbaril e carbofurano pode-se observar que eles não se alteraram, mas para os compostos aldicarbe, simazina e trifluralina estes apresentaram uma diminuição, indicando uma melhora nos LD e LQ destes compostos quando comparados com os valores obtidos por Lebre.

\subsubsection{Estudo de recuperação}

Uma das maneiras de se determinar a exatidão do método analítico é aplicar a metodologia em amostras contendo quantidades conhecidas dos compostos de interesse (Lebre, 2000; Taylor, 1983). Dessa forma, a cada coleta realizada uma amostra de água superficial, uma amostra de água tratada e uma amostra água ultrapura (considerada "branco"), para avaliar a eficiência do processo de extração utilizou-se o processo de adição de padrão (concentração final de $4 \mu \mathrm{gL}^{-1}$ de cada composto).

Deste modo obteve-se no final do programa 6 amostras de água superficial, 6 amostras de água tratada e 12 amostras de água ultrapura para o estudo de recuperação do método. Os resultados da recuperação estão apresentados na TAB.19.

TABELA 19 - Estudo de recuperação dos compostos avaliados em amostras de água ultrapura, água superficial e água tratada.

\begin{tabular}{cccccccccc}
\hline \multirow{2}{*}{ Compostos } & \multicolumn{3}{c}{ Água ultrapura } & \multicolumn{3}{c}{ Água superficial } & \multicolumn{3}{c}{ Água tratada } \\
\cline { 2 - 10 } & $\begin{array}{c}\text { Rec. } \\
(\%)\end{array}$ & DRP & $\begin{array}{c}\text { CV } \\
(\%)\end{array}$ & $\begin{array}{c}\text { Rec. } \\
(\%)\end{array}$ & DRP & $\begin{array}{c}\text { CV } \\
(\%)\end{array}$ & $\begin{array}{c}\text { Rec. } \\
(\%)\end{array}$ & DRP & $\begin{array}{c}\text { CV } \\
(\%)\end{array}$ \\
\hline Aldicarbe & 32 & 13 & 41 & 89 & 21 & 24 & 92 & 27 & 29 \\
\hline Simazima & 92 & 7 & 8 & 106 & 8 & 8 & 105 & 9 & 9 \\
\hline Carbofurano & 108 & 7 & 6 & 101 & 9 & 9 & 104 & 10 & 10 \\
\hline Carbaril & 105 & 7 & 7 & 108 & 6 & 5 & 105 & 8 & 8 \\
\hline Atrazina & 88 & 10 & 12 & 106 & 5 & 5 & 109 & 16 & 15 \\
\hline Trifluralina & 56 & 14 & 25 & 64 & 14 & 22 & 64 & 7 & 11 \\
\hline
\end{tabular}

$\mathrm{n}=6$ para as amostras de água superficial e tratada e 12 para amostras de água ultrapura.

$\operatorname{Rec}=$ recuperação e $\mathrm{DRP}=$ desvio padrão relativo e $\mathrm{CV}=$ coeficiente de variação. 
Embora os valores de desvio padrão relativos (DPR) obtidos não foram tão baixos quanto os obtidos por Lebre (2000) são menores que os $30 \%$ considerados pela EPA (Barceló, 1993). Também neste estudo o aldicabe e a trifluralina foram os compostos que apresentaram as menores porcentagens de recuperação e maiores valores de DPR.

Segundo Lebre (2000) a baixa recuperação da trifluralina está associada a sua alta massa molecular e baixa polaridade possuindo forte afinidade pelo material extrator. O inverso ocorre com o aldicarbe que possui baixo peso molecular e solubilidade em água relativamente alta $\left(4,93 \mathrm{gL}^{-1}\right)$. Lebre, ainda, levanta a hipótese de que o aldicarbe quando associado ao ácido húmico, presente nas amostras de água superficial e tratada, tenha sua solubilidade diminuída, aumentando sua carga e afinidade com o material extrator, melhorando a sua recuperação, como pode ser observado na TAB.19. Balinova (1996) afirma que colunas de SPE empacotadas com $C_{18}$ não são ideais para extração de compostos altamente polares como aldicarbe, metomil e dimetoato em amostras de água, pois as recuperações são muito baixas.

\subsection{Desenvolvimento e otimização da metodologia para determinação de carbamatos, triazinas e nitroanilinas utilizando LC - MS/MS.}

Nas TAB.20 e 21 são apresentados os íons produzidos por cada um dos compostos e determinando-se o melhor par iônico e as melhores energias de fragmentação para detecção dos íons selecionados. Na FIG.27 são apresentados os espectros de massas dos carbamatos estudados, um espectro MS/MS e um espectro de um íon precursor do carbofurano.

O ESI (Electrospray Ionization), APCI (Atmospheric Pressure Chemical Ionization) e APPI (Atmospheric Pressure Photonization) são processos complexos, têm muitos parâmetros instrumentais, os quais influenciam drasticamente na eficiência da ionização, por isso foi necessário se fazer uma otimização cuidadosa do espectrômetro de massas para obter sua máxima sensibilidade (Asperger et al, 2001; Robb et al, 2000). 
TABELA 20 - Valores otimizados para os parâmetros da interface e o gás de colisão.

$(+)$ TurbolonSpray ${ }^{\circledR}$

$\begin{array}{cc}\text { IS voltagem } & 5300 \mathrm{~V} \\ \text { Temperatura } & 500^{\circ} \mathrm{C} \\ \text { IS gás } 1 \text { (nebulizante) } & 45 p . s . i \\ \text { IS gás 2 (secante) } & 45 p . s . i . \\ \text { Curtain gas }^{*} & 12 \text { p.s.i. }\end{array}$

Gás de colisão $\left(\mathrm{N}_{2}\right)$

5u.a.

*Cortina de gás o termo em inglês é usado comumente na área de espectrometria de massas.

u.a. = unidades arbitrárias.

TABELA 21 - Parâmetros de operação para as medidas de MS/MS.

\begin{tabular}{cccccccc}
\hline Composto & $\begin{array}{c}\text { Massa } \\
\text { Molecular }\end{array}$ & $\begin{array}{c}\text { Íon } \\
\text { Precursor }\end{array}$ & Ion Produto & $\begin{array}{c}\text { Dwell } \\
(\mathbf{m s e c})\end{array}$ & $\begin{array}{c}\text { DP } \\
(\mathrm{V})\end{array}$ & $\begin{array}{c}\text { CE } \\
(\mathrm{V})\end{array}$ & $\begin{array}{c}\text { CXP } \\
\text { (V) }\end{array}$ \\
\hline Aldicarbe & 189 & 208 & 116 & 200 & 31 & 11 & 20 \\
\hline $\begin{array}{c}\text { Aldicarbe } \\
\text { sulfona }\end{array}$ & 201 & 223 & 86 & 200 & 71 & 23 & 14 \\
\hline Atrazina & 197 & 216 & 174 & 200 & 86 & 25 & 30 \\
\hline Carbaril & 183 & 202 & 145 & 200 & 56 & 15 & 24 \\
\hline Carbofurano & 203 & 222 & 165 & 200 & 66 & 17 & 28 \\
\hline $\begin{array}{c}\text { 3-hidróxi- } \\
\text { carbofurano }\end{array}$ & 219 & 238 & 163 & 200 & 66 & 21 & 28 \\
\hline Metomil & 144 & 163 & 88 & 200 & 51 & 13 & 14 \\
\hline $\begin{array}{c}\text { Simazina } \\
\text { Trifluralina }\end{array}$ & 183 & 202 & 132 & 200 & 36 & 27 & 22 \\
\hline $\begin{array}{l}\text { DP = "declustering potential" - potencial aplicado na interface do vácuo; CE = energia de colisão e CXP } \\
\text { potencial de saída da célula de colisão. }\end{array}$ & & & & &
\end{tabular}




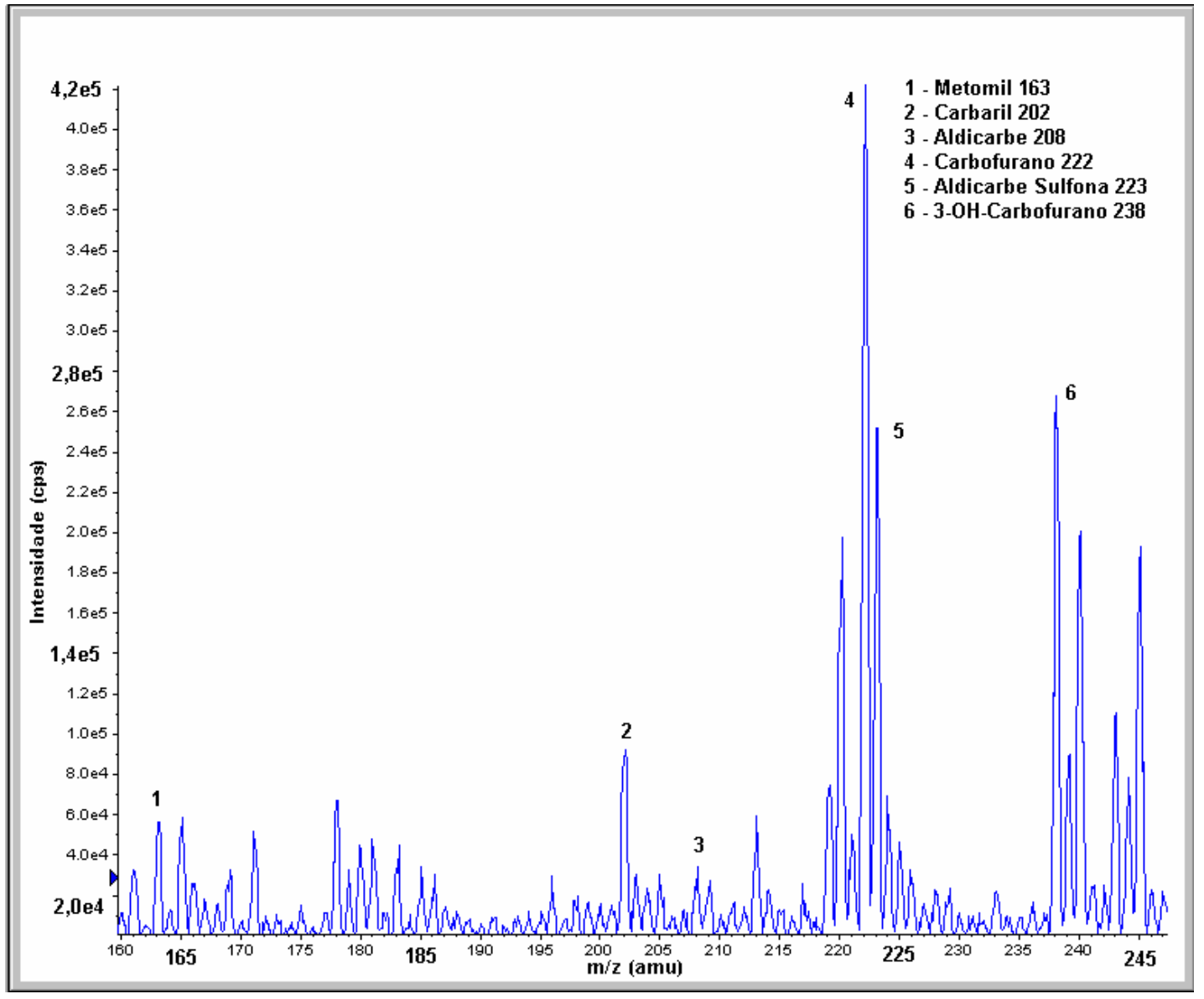

(a)

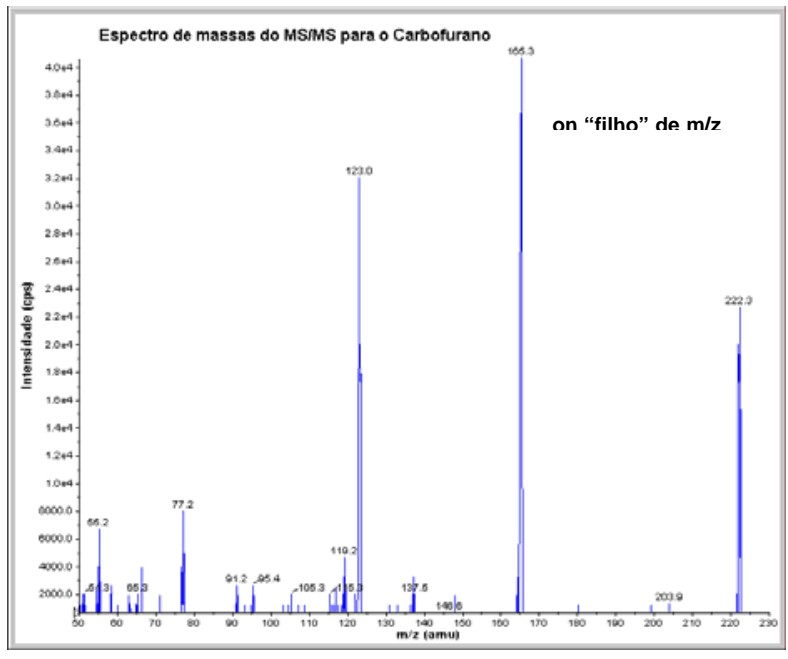

(b)

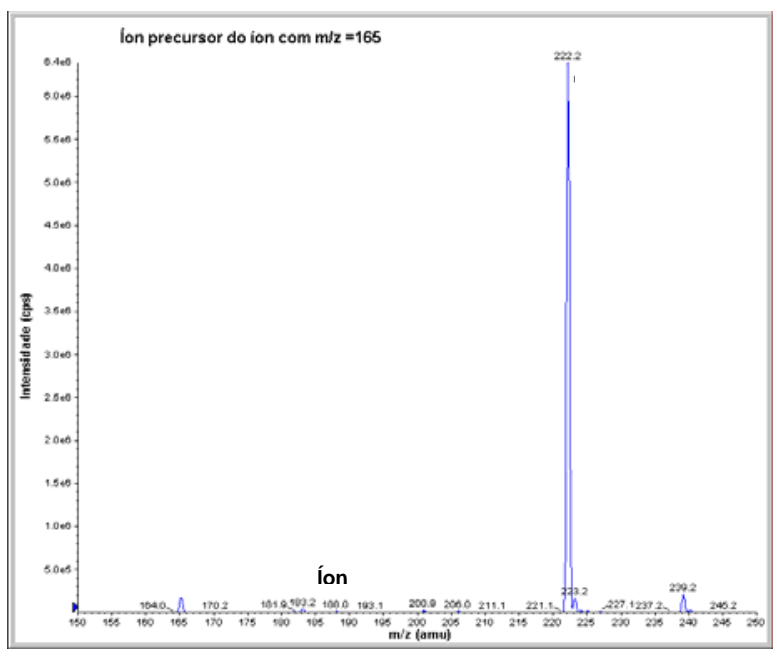

(c)

FIGURA 27 - (a) do espectro de massas dos carbamatos, (b) o espectro de massas MS/MS do carbofurano e (c) espectro de identificação do precursor (carbofurano) do íon produto de $\mathrm{m} / \mathrm{z}=165$. 
Determinadas as condições do MS/MS acoplou-se o equipamento ao cromatografo líquido de alta eficiência - LC e ajustaram-se os parâmetros da fonte de íons por electrospray para condição de análise por injeção em fluxo (Flow injection analysis). Otimizaram-se os parâmetros cromatográficos aplicando-se um gradiente na solução eluente (TAB.22). Na FIG.28 é apresentado um cromatograma obtido nas condições ótimas de análise dos analítos.

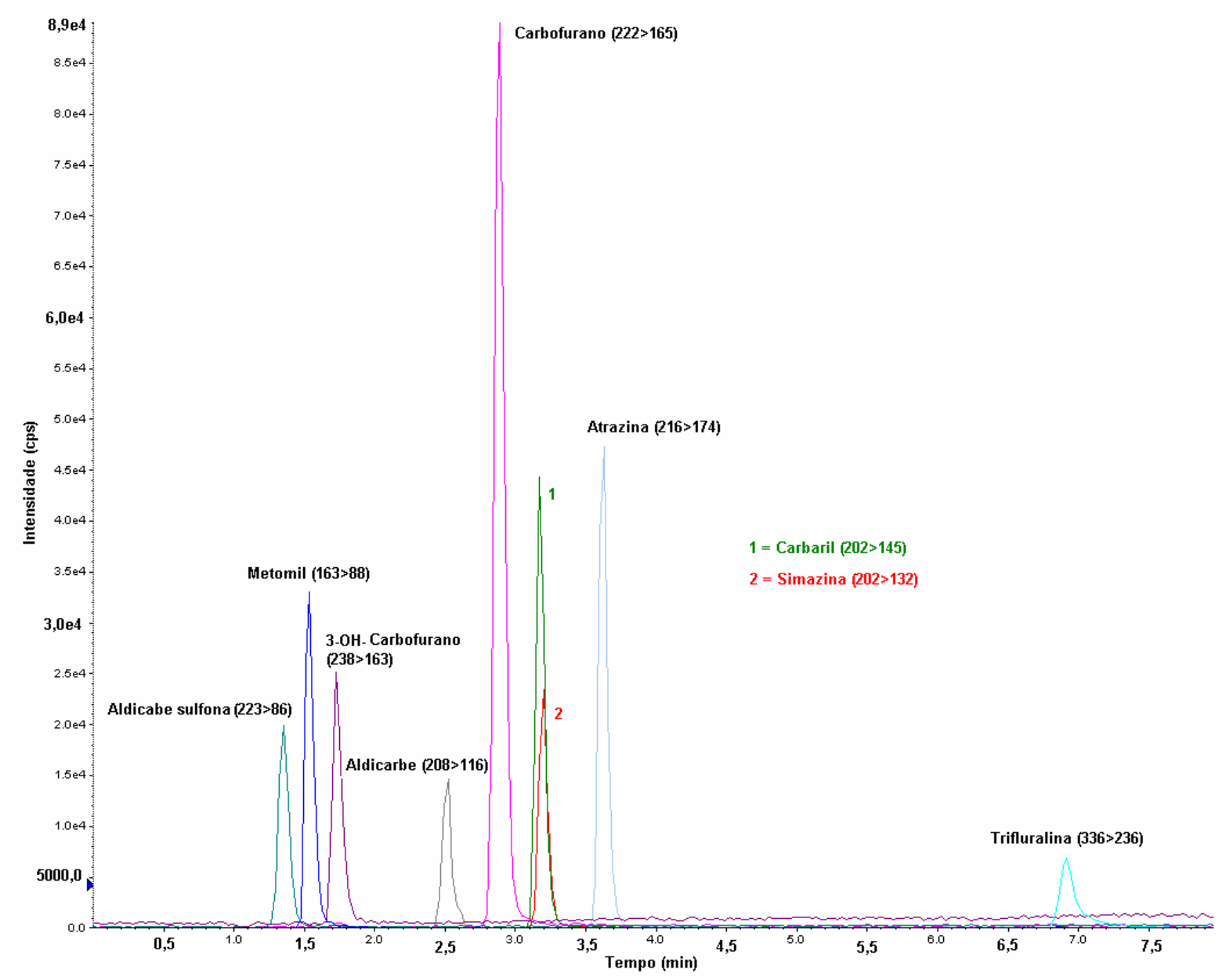

FIGURA 28 - Cromatograma dos compostos analisados nas concentrações de $2,0 \mathrm{ngmL}^{-1}$ para os carbamatos e triazinas e $200 \mathrm{ngmL}^{-1}$ para trifluralina utilizando LC - MS/MS 
TABELA 22 - Condições cromatográficas e gradiente das soluções eluentes.

\begin{tabular}{cccccc}
\hline Etapas & $\begin{array}{c}\text { Tempo total } \\
(\mathbf{m i n})\end{array}$ & $\begin{array}{c}\text { Fluxo } \\
\left(\mu \mathbf{l m i n}^{-1}\right)\end{array}$ & $\begin{array}{c}\text { Vol. de Injeção } \\
(\mu \mathrm{L})\end{array}$ & Água (\%) & Metanol (\%) \\
\hline 0 & 3,00 & 700 & 20 & 35 & 65 \\
\hline 1 & 0,00 & 700 & 20 & 35 & 65 \\
\hline 2 & 1,00 & 700 & 20 & 10 & 90 \\
\hline 3 & 4,00 & 700 & 20 & 10 & 90 \\
\hline 4 & 4,01 & 700 & 20 & 05 & 95 \\
\hline 5 & 8,00 & 700 & 20 & 05 & 95 \\
\hline
\end{tabular}

\subsubsection{Estudo de linearidade}

Verificou-se que a sensibilidade para a trifluralina foi menor que a dos outros componentes estudados, portanto, na construção das curvas analíticas utilizaram-se concentrações 100 vezes maiores que os outros compostos. As curvas analíticas foram construídas diluindo-se as soluções padrão aquosas e em solução $50 \%$ acetonitrila (ACN) e água $V / N$, para analisar as amostras de injeção direta e amostras que passaram por extração em SPE, respectivamente. Avaliouse a correlação entre a concentração e a área dos picos através da regressão linear.

Nas TAB.23 e 24 apresentam-se as faixas de estudos da linearidade, as equações das curvas analíticas e os fatores de regressão linear $\left(r^{2}\right)$ obtidos para os compostos em estudo, onde os padrões foram diluídos em água ultrapura e solução de $A C N 50 \%$ em água $V / N$, respectivamente. No dois casos as curvas apresentaram boa linearidade para todos os compostos em uma faixa de variação de até 100 vezes da primeira para a ultima concentração. Na TAB.24 são apresentados os limites de detecção e de quantificação calculados conforme as Equações 1 e 2, no item 6.3.1. 
TABELA 23 - Parâmetros obtidos no estudo de linearidade com padrões diluídos em água ultrapura

\begin{tabular}{cccc}
\hline Composto & $\begin{array}{c}\text { Faixa de estudo da } \\
\text { linearidade }\left(\mathbf{n g L}^{-1}\right)\end{array}$ & Equação de calibração & $\mathbf{R}^{2}$ \\
\hline Aldicarbe & $25-2.000$ & $\mathrm{y}=3,58.10^{4} \mathrm{x}-114$ & 0,9970 \\
\hline Aldicarbe sulfona & $25-2.000$ & $\mathrm{y}=5,50.10^{4} \mathrm{x}+239$ & 0,9997 \\
\hline Atrazina & $25-2.000$ & $\mathrm{y}=1,10.10^{5} \mathrm{x}-266$ & 0,9996 \\
\hline Carbaril & $25-2.000$ & $\mathrm{y}=1,02.10^{5} \mathrm{x}-15$ & 0,9988 \\
\hline Carbofurano & $25-2.000$ & $\mathrm{y}=2,41.10^{5} \mathrm{x}-413$ & 0,9999 \\
\hline 3-hidróxi-carbofurano & $25-2.000$ & $\mathrm{y}=6,13.10^{4} \mathrm{x}+1,03.10^{3}$ & 0,9989 \\
\hline Metomil & $25-2.000$ & $\mathrm{y}=7,45.10^{4} \mathrm{x}-95,3$ & 0,9991 \\
\hline Simazina & $25-2.000$ & $y=5,56.10^{4} \mathrm{x}-266$ & 0,9995 \\
\hline Trifluralina & $2,5.10^{3}-0,2.10^{5}$ & $y=27,20 \mathrm{x}-24,7$ & 0,9965 \\
\hline
\end{tabular}

TABELA 24 - Parâmetros obtidos no estudo de linearidade com padrões diluídos em solução $50 \%$ ACN e água ultrapura

\begin{tabular}{|c|c|c|c|c|c|}
\hline Composto & $\begin{array}{c}\text { Faixa de estudo } \\
\text { da linearidade } \\
\left(\mathrm{ngL}^{-1}\right)\end{array}$ & $\begin{array}{c}\text { Equação de } \\
\text { calibração }\end{array}$ & $\mathbf{R}^{2}$ & $\begin{array}{c}\text { Limite de } \\
\text { Detecção } \\
\left(\mathrm{ngL}^{-1}\right)^{\mathrm{a}} \\
\end{array}$ & $\begin{array}{c}\text { Limite de } \\
\begin{array}{c}\text { Quantificação } \\
\left(n \mathrm{~nL}^{-1}\right)^{\mathrm{a}}\end{array} \\
\end{array}$ \\
\hline Aldicarbe & $25-2.000$ & $y=3,32 \cdot 10^{4} x+269$ & 0,9972 & $4,9 \pm 1,9$ & $14,5 \pm 8,3$ \\
\hline $\begin{array}{l}\text { Aldicarbe } \\
\text { sulfona }\end{array}$ & $25-2.000$ & $y=5,89.10^{4} x-869$ & 0,9985 & $14,6 \pm 4,7$ & $59,8 \pm 13,2$ \\
\hline Atrazina & $25-2.000$ & $y=1,09.10^{5} x-57,6$ & 0,9992 & $3,1 \pm 1,2$ & $10,1 \pm 3,6$ \\
\hline Carbaril & $25-2.000$ & $y=1,07 \cdot 10^{5} x+103$ & 0,9997 & $1,8 \pm 0,7$ & $5,9 \pm 1,6$ \\
\hline Carbofurano & $25-2.000$ & $y=2,39.10^{5} x-256$ & 0,9995 & $1,8 \pm 0,3$ & $6,1 \pm 1,5$ \\
\hline $\begin{array}{c}\text { 3-hidróxi- } \\
\text { carbofurano }\end{array}$ & $25-2.000$ & $y=6,54 \cdot 10^{3} x+42,1$ & 0,9995 & $17,3 \pm 4,3$ & $57,5 \pm 17,1$ \\
\hline Metomil & $25-2.000$ & $y=7,35 \cdot 10^{4} x-1,1 \cdot 10^{3}$ & 0,9994 & $4,4 \pm 1,2$ & $16,2 \pm 6,3$ \\
\hline Simazina & $25-2.000$ & $y=5,54 \cdot 10^{4} x-219$ & 0,9994 & $4,5 \pm 1,4$ & $13,7 \pm 3,8$ \\
\hline Trifluralina & $2,5.10^{3}-0,2.10^{5}$ & $y=27,50 x-15,5$ & 0,9992 & $1,9 \cdot 10^{3} \pm 0,8$ & $2,6.10^{3} \pm 2,8$ \\
\hline
\end{tabular}


Os valores de LD e LQ obtidos para esta técnica mostram o quanto está técnica é mais sensível que a LC-UV/Vis. Foram obtidas concentrações da ordem de $\mathrm{ngL}^{-1}$, valores bem menores que $\circ 0,1 \mu \mathrm{gL}^{-1}$ exigido pela legislação da Comunidade Econômica Européia (EEC) (Barceló, 1993). Exceto para a trifluralina, a qual se trabalhou com concentrações de $\mu \mathrm{gL}^{-1}$, mas mesmo assim estes valores estão abaixo do valor máximo permissível da Portaria de potabilidade $\mathrm{n}^{-5} 518 / \mathrm{MS} / 04$ que é $20 \mu \mathrm{gL}^{-1}$.

\subsubsection{Estudo de recuperação}

Realizou-se o estudo de recuperação dos compostos para o método por injeção direta e utilizando a extração com SPE.

No estudo de recuperação por injeção direta adicionaram-se soluções padrão em concentrações, extremamente baixas, próximas ao limite de 0,025 ; 0,05 e $0,10 \mathrm{ngmL}^{-1}$, com exceção da trifuluralina a qual foi estudada na concentração de $5, \mathrm{OngmL}^{-1}$, em amostras de água ultrapura e água superficial. Essas foram realizadas em triplicata totalizando seis amostras para cada concentração.

As médias das recuperações com seus respectivos desvios padrões e coeficientes de variação estão apresentados nas TAB.25. Como se pode observar os valores de recuperação obtidos encontram-se na faixa de $70 \%$ a $111 \%$ e com coeficiente de variação $(\mathrm{CV})$ dentro da faixa dos $30 \%$ para quase todos compostos, mostrando o bom desempenho do método para injeção direta, os mesmo em concentrações próximas do LD.

Para o estudo de recuperação, aplicando-se o processo de prétratamento da amostra de extração com SPE, inicialmente, fortificou-se $250 \mathrm{~mL}$ de amostras de água ultrapura e superficial na concentração de $10 \mathrm{ng}^{-1}$ de cada composto. Todos os ensaios foram feitos em triplicata. Os resultados estão apresentados na TAB.26. 
TABELA 25 - Resultados do ensaio de recuperação dos agrotóxicos utilizando injeção direta no sistema LC - MS/MS

\begin{tabular}{|c|c|c|c|c|c|c|c|c|c|c|c|c|}
\hline \multirow{3}{*}{ Compostos } & \multicolumn{12}{|c|}{ Concentrações $\left(\mathrm{ngmL}^{-1}\right)$} \\
\hline & \multicolumn{4}{|c|}{0,025} & \multicolumn{4}{|c|}{0,05} & \multicolumn{4}{|c|}{0,10} \\
\hline & $\mathbf{n}$ & $\begin{array}{c}R \\
\text { (\%) }\end{array}$ & DP & $\begin{array}{c}\text { CV } \\
\text { (\%) }\end{array}$ & $\mathbf{n}$ & $\begin{array}{c}R \\
\text { (\%) }\end{array}$ & DP & $\begin{array}{l}\text { CV } \\
\text { (\%) }\end{array}$ & $\mathbf{n}$ & $\begin{array}{c}R \\
(\%)\end{array}$ & DP & $\begin{array}{c}\mathrm{CV} \\
\text { (\%) }\end{array}$ \\
\hline Aldicarbe & 3 & 106 & 28,4 & 26,8 & 6 & 78 & 16,8 & 21,5 & 6 & 69 & 33,2 & 48,1 \\
\hline Aldicarbe sulfona & 5 & 59 & 22,8 & 38,6 & 6 & 87 & 11,3 & 13,0 & 6 & 82 & 9,7 & 11,8 \\
\hline Atrazina & 3 & 99 & 8,5 & 8,6 & 6 & 102 & 13,3 & 13,0 & 6 & 99 & 11,9 & 12,0 \\
\hline Carbaril & 4 & 99 & 15,6 & 15,8 & 6 & 98 & 12,0 & 12,2 & 6 & 99 & 5,2 & 5,2 \\
\hline Carbofurano & 6 & 104 & 11,6 & 11,2 & 6 & 103 & 8,0 & 7,8 & 6 & 98 & 8,2 & 8,4 \\
\hline 3-hidróxi-carbofurano & 3 & 69 & 18,6 & 27,0 & 6 & 72 & 17,2 & 23,9 & 6 & 82 & 10,6 & 13,0 \\
\hline Metomil & 5 & 90 & 7,3 & 8,1 & 6 & 92 & 7,0 & 7,6 & 6 & 82 & 6,2 & 7,6 \\
\hline Simazina & 4 & 111 & 15,2 & 13,7 & 6 & 101 & 12 & 11,9 & 6 & 106 & 15,8 & 14,9 \\
\hline Trifluralina & nd & nd & nd & nd & 6 & 88 & 15 & 17,0 & nd & nd & nd & nd \\
\hline
\end{tabular}

Onde: $\mathrm{n}=\mathrm{o}$ número de amostras utilizadas para calcular a recuperação; $\mathrm{DP}=$ desvio padrão; $\mathrm{R}=$ recuperação e CV = coeficiente de variação. $\square$ Concentração da trifluralina $=5,0 \mathrm{ngmL}^{-1}$

Para explorar a sensibilidade e seletividade da técnica bem como propor um método mais sensível Optou-se por estudar as recuperações em baixas concentrações.

Como se pode observar na TAB.26 para o método SPE LC - MS/MS obteve-se boa recuperação, na faixa de $79 \%$ a $101 \%$, para cinco dos nove compostos analisados. Os compostos aldicarbe, aldicarbe sulfona, metomil e trifluralina apresentaram uma recuperação abaixo de $70 \%$ o que já era previsível uma vez que estes compostos apresentaram baixa recuperação no método SPE LC - UV/Vis. 
TABELA 26 - Recuperação do método SPE - LC - MS/MS em amostras de água ultrapura e água superficial

\begin{tabular}{|c|c|c|c|c|c|c|c|c|}
\hline Amostras & \multicolumn{4}{|c|}{ Água ultrapura } & \multicolumn{4}{|c|}{ Água Superficial } \\
\hline \multirow{2}{*}{$\frac{\text { Concentrações }}{\text { Compostos }}$} & \multicolumn{4}{|c|}{$10,0 \mathrm{ngL}^{-1}$} & \multicolumn{4}{|c|}{$10,0 \mathrm{ngL}^{-1}$} \\
\hline & $\mathbf{n}$ & R (\%) & DP & CV & $\mathbf{n}$ & R (\%) & DP & $\mathrm{CV}$ \\
\hline Aldicarbe & 2 & 4 & 2,2 & 55 & 2 & 68 & 3,9 & 5,7 \\
\hline Aldicarbe sulfona & 3 & 27 & 4 & 14,8 & 3 & 23 & 6,2 & 26,9 \\
\hline Atrazina & 3 & 80 & 3,5 & 4,3 & 3 & 96 & 14,1 & 14,7 \\
\hline Carbaril & 3 & 96 & 5,5 & 5,7 & 3 & 94 & 3,9 & 4,1 \\
\hline Carbofurano & 3 & 95 & 7,8 & 8,2 & 3 & 97 & 2,3 & 2,3 \\
\hline 3-hidróxi-carbofurano & 3 & 101 & 18,3 & 18,1 & 3 & 95 & 7,1 & 7,4 \\
\hline Metomil & 3 & 18 & 5,9 & 32,8 & 3 & 23 & 0,9 & 3,9 \\
\hline Simazina & 3 & 90 & 6,4 & 9,4 & 3 & 79 & 3,7 & 4,6 \\
\hline Trifluralina & 3 & 54 & 14,4 & 26,7 & 3 & 54 & 12,1 & 22,1 \\
\hline
\end{tabular}

Onde: $\mathrm{n}=$ o número de amostras utilizadas para calcular a recuperação; $\mathrm{DP}=$ desvio padrão; $\mathrm{R}=$ recuperação e CV = coeficiente de variação.

$\mathrm{Na}$ TAB. 27 são apresentados os limites de detecção e de quantificação calculados conforme as Equações 1 e 2, no item 6.3.1., em amostras de água superficial, para o método SPE - LC - MS/MS. Quando se compara o limite de detecção para o método com os limites de detecção de alguns trabalhos na literatura consultada, apresentados na TAB.28, verifica-se o quanto este método é sensível para os compostos estudados. Com exceção da trifluralina que apresenta limites melhores na cromatografia a gás. 
TABELA 27 - Limites de detecção e quantificação obtidos para o método SPE - LC - MSIMS

\begin{tabular}{ccc}
\hline Composto & $\begin{array}{c}\text { Limite de Detecção } \\
\left(\mathbf{n g L}^{-1}\right)^{\mathbf{a}}\end{array}$ & $\begin{array}{c}\text { Limite de Quantificação } \\
\left(\mathbf{n g L}^{-1}\right)^{\mathbf{a}}\end{array}$ \\
\hline Aldicarbe & 0,09 & 0,27 \\
\hline Aldicarbe sulfona & 1,23 & 3,70 \\
\hline Atrazina & 0,04 & 0,13 \\
\hline Carbaril & 0,02 & 0,08 \\
\hline Carbofurano & 0,02 & 0,06 \\
\hline 3-hidróxi-carbofurano & 0,37 & 1,20 \\
\hline Metomil & 0,15 & 0,77 \\
\hline Simazina & 0,04 & 0,14 \\
\hline Trifluralina & 74,07 & 238,09
\end{tabular}

TABELA 28 - Relação do limite de detecção de alguns métodos multiresíduos adotado pela literatura consultada

\begin{tabular}{|c|c|c|c|c|c|c|c|c|c|}
\hline $\begin{array}{l}\frac{\mathscr{0}}{2} \\
\frac{0}{0} \\
\frac{0}{0} \\
\frac{0}{\alpha}\end{array}$ & 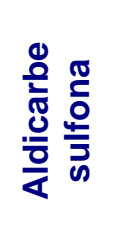 & 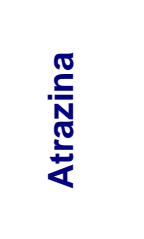 & 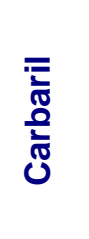 & $\begin{array}{l}\stackrel{0}{5} \\
\frac{0}{5} \\
\frac{2}{0} \\
\frac{0}{2} \\
0 \\
0\end{array}$ & 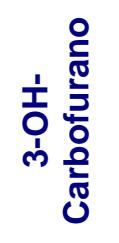 & $\begin{array}{l}\overline{\bar{\xi}} \\
\overline{0} \\
\text { ¿ँ }\end{array}$ & 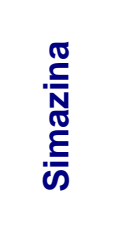 & 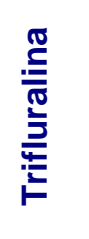 & $\begin{array}{c}\text { Referências } \\
\text { Método }\end{array}$ \\
\hline \multicolumn{10}{|c|}{$\left[\mathrm{ngL}^{-1}\right]$} \\
\hline NA & NA & 20 & NA & NA & NA & NA & 3 & 1 & $\begin{array}{l}\text { Albanis, } 1998 \\
\text { SPE-GC-MS }\end{array}$ \\
\hline NA & NA & 9 & NA & NA & NA & NA & 20 & 5 & $\begin{array}{l}\text { Azevedo, } 2000 \\
\text { SPE-GC-MS }\end{array}$ \\
\hline NA & NA & $2.10^{4}$ & NA & NA & NA & NA & $2.10^{4}$ & NA & $\begin{array}{c}\text { Azevedo, } 2000 \\
\text { SPE-LC-APCI-MS }\end{array}$ \\
\hline NA & NA & $2,4.10^{3}$ & NA & NA & NA & NA & $6,3.10^{3}$ & NA & $\begin{array}{c}\text { EPA-US, 2004a } \\
\text { 505/ME-GC-ECD }\end{array}$ \\
\hline 15 & NA & NA & NA & NA & NA & NA & 14 & NA & $\begin{array}{c}\text { EPA-US, 2004a } \\
507 / G C-N P D\end{array}$ \\
\hline NA & NA & 3 & NA & NA & NA & NA & 8 & 1 & $\begin{array}{c}\text { EPA-US, 2004a } \\
\text { 508/SPE-GC-ECD }\end{array}$ \\
\hline NA & NA & 78 & NA & NA & NA & NA & 150 & 96 & $\begin{array}{c}\text { EPA-US, 2004a } \\
\text { 525.2/SPE(coluna) } \\
\text { - GC-MS }\end{array}$ \\
\hline
\end{tabular}


TABELA 28 - Relação do limite de detecção de alguns métodos multiresíduos adotado pela literatura consultada (continuação)

\begin{tabular}{|c|c|c|c|c|c|c|c|c|c|}
\hline 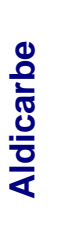 & 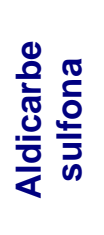 & 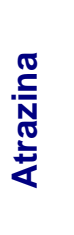 & 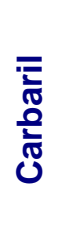 & 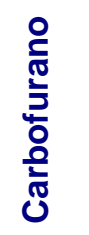 & 市 & $\begin{array}{l}\overline{\bar{\varepsilon}} \\
\overline{0} \\
\bar{d}\end{array}$ & 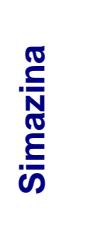 & 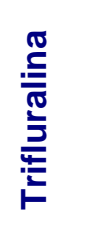 & $\begin{array}{c}\text { Referências } \\
\text { Método }\end{array}$ \\
\hline \multicolumn{10}{|c|}{$\left[\mathrm{ngL}^{-1}\right]$} \\
\hline NA & NA & 65 & NA & NA & NA & NA & 180 & 48 & $\begin{array}{c}\text { EPA-US, 2004a } \\
\text { 525.2/ SPE(disco) - } \\
\text { GC-MS }\end{array}$ \\
\hline NA & NA & 81 & NA & NA & NA & NA & 130 & 240 & $\begin{array}{c}\text { EPA-US, 2004a } \\
\text { 525.2/SPE(coluna) } \\
\text { - GC-IT-MS }\end{array}$ \\
\hline NA & NA & 76 & NA & NA & NA & NA & 45 & 140 & $\begin{array}{c}\text { EPA-US, 2004a } \\
\text { 525.2/ SPE(disco) - } \\
\text { GC-IT-MS }\end{array}$ \\
\hline 26 & 57 & NA & 45 & 43 & 29 & 50 & NA & NA & $\begin{array}{c}\text { EPA-US, 2004a } \\
531.2 / \mathrm{LC}^{1}\end{array}$ \\
\hline 42 & 26 & NA & 65 & 58 & 41 & 45 & NA & NA & $\begin{array}{c}\text { EPA-US, 2004a } \\
531.2 / \mathrm{LC}^{2}\end{array}$ \\
\hline 49 & 33 & NA & 43 & 50 & 38 & 54 & NA & NA & $\begin{array}{c}\text { EPA-US, 2004a } \\
531.2 / \text { LC }^{3}\end{array}$ \\
\hline NA & NA & NA & 40 & NA & NA & NA & 100 & 6 & $\begin{array}{l}\text { Komatsu, } 2004 \\
\text { SPEM GC - MS }\end{array}$ \\
\hline 489 & NA & 24 & 17 & 129 & NA & NA & 26 & 448 & $\begin{array}{c}\text { Lebre, } 2000 \\
\text { SPE-LC-UV/Vis }\end{array}$ \\
\hline
\end{tabular}

$1=$ waters postcolumn carbamate system and the waters model 474 detector

$2=$ pickering model pcx5200 postcolumn system and the waters model 474 detector

$3=$ waters postcolumn carbamate analysis system and the waters model 2475 detector

NA = Não analisado. 


\subsection{Variação dos parâmetros físicos e químicos da água superficial e tratada}

A Unidade de Negócios do Vale do Ribeira da SABESP trabalha com um sistema automatizado nas ETAs, integrado por um centro de controle operacional, na cidade de Registro. Por meio do banco de dados gerado por este sistema, durante o período de coleta, construíram-se gráficos do tipo Blox-plot para os parâmetros cor, turbidez e pH da água superficial e tratada, apresentados nas FIG.29, 30 e 31, dos municípios estudados neste trabalho.

As representações de Blox-plot possibilitam a visualização das seguintes grandezas estatísticas: a média, a mediana (divide o conjunto de dados ao meio, deixando metade dos dados abaixo e metade acima dela), o primeiro quartil (é o valor que deixa $1 / 4$ das observações abaixo dele), o terceiro quartil (é o valor que deixa $3 / 4$ das observações abaixo dele) e o máximo e o mínimo são os valores extremos da distribuição dos dados.

Deve-se dar uma atenção especial aos pontos extremos, pois podem indicar erros de amostragem, de medida e, mesmo, de transcrição dos dados, ou ainda, simplesmente, um comportamento fora do habitual. Além de afetarem a média e a variabilidade dos dados, podendo até distorcer o resultado das inferências estatísticas.

Na FIG.29 são representados os gráficos Blox-plot de pH para água superficial e tratada dos municípios estudados durante o período de janeiro de 2002 a dezembro de 2003.

Na FIG.30 são representados os gráficos Blox-plot de cor para água superficial e tratada dos municípios estudados durante o período de janeiro de 2002 a dezembro de 2003.

Na FIG.31 são representados os gráficos Blox-plot de turbidez para água superficial e tratada dos municípios estudados durante o período de janeiro de 2002 a dezembro de 2003. 


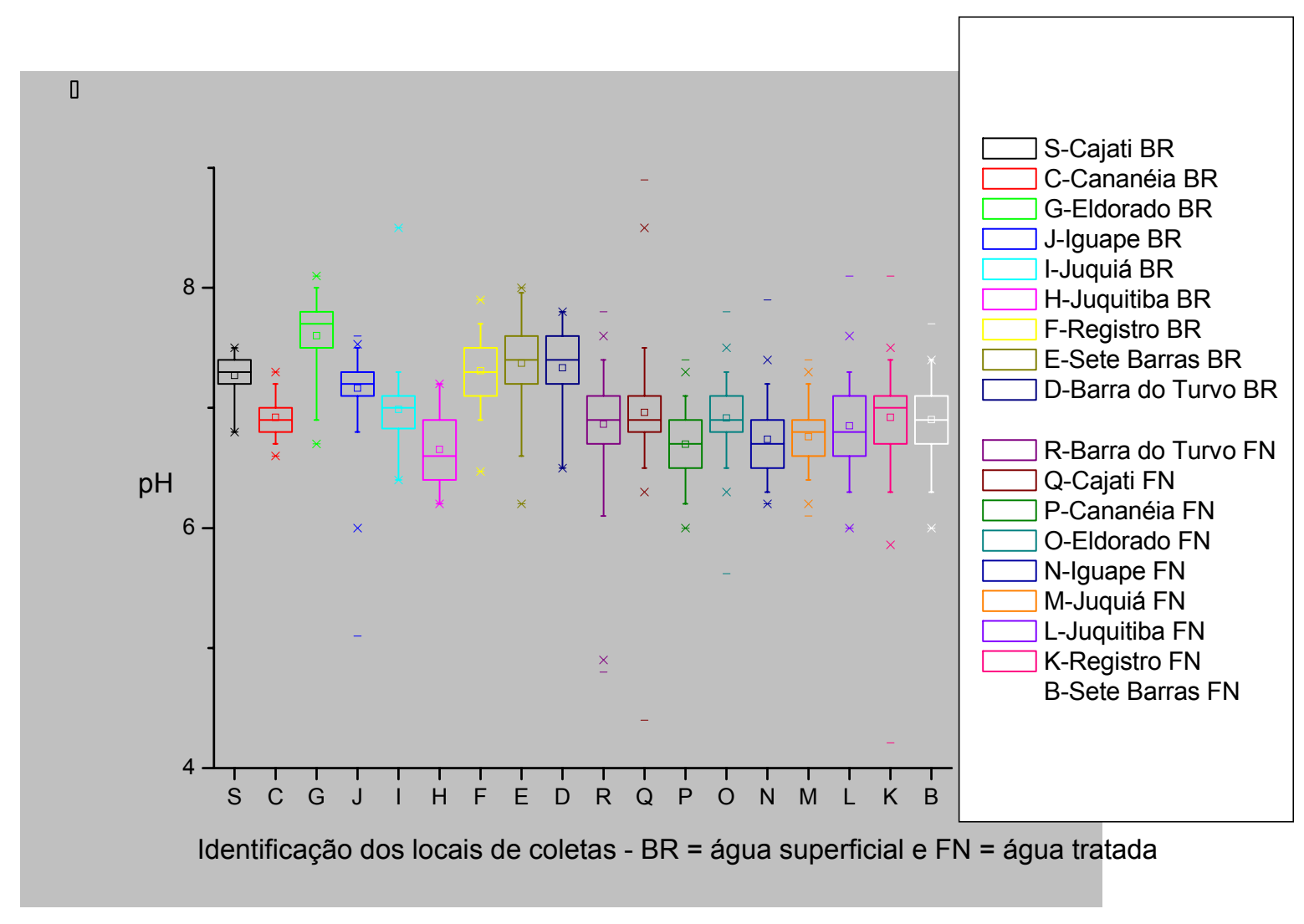

FIGURA 29 - Índice de pH de água superficial e tratada por município

Tanto as amostras de água superficial quanto as amostras de água tratada apresentaram faixas de $\mathrm{pH}$ entre 6 e 8 . Esta amplitude atende aos valores estabelecidos de $\mathrm{pH}$ exigida pela Portaria $\mathrm{n}^{\circ}$ 518/MS/04 (6,0-9,5) bem como da Resolução CONAMA no $20 / 86$, para corpos d água classe 2 . Com exceção de dos pontos mínimos de Iguape BR (água superficial), Barra do Turvo FN (água tratada); Cajati FN, Eldorado FN e Registro FN que apresentaram pH entre 4,5 e 5; esses pontos ocorreram no período de cheia e em dias de chuva.

Com relação aos valores obtidos para $\mathrm{opH}$ da água tratada foi observado o controle perfeito na eficiência do tratamento, pois os dados apresentaram uma homogeneidade com valores próximos do $\mathrm{pH} 7$. 


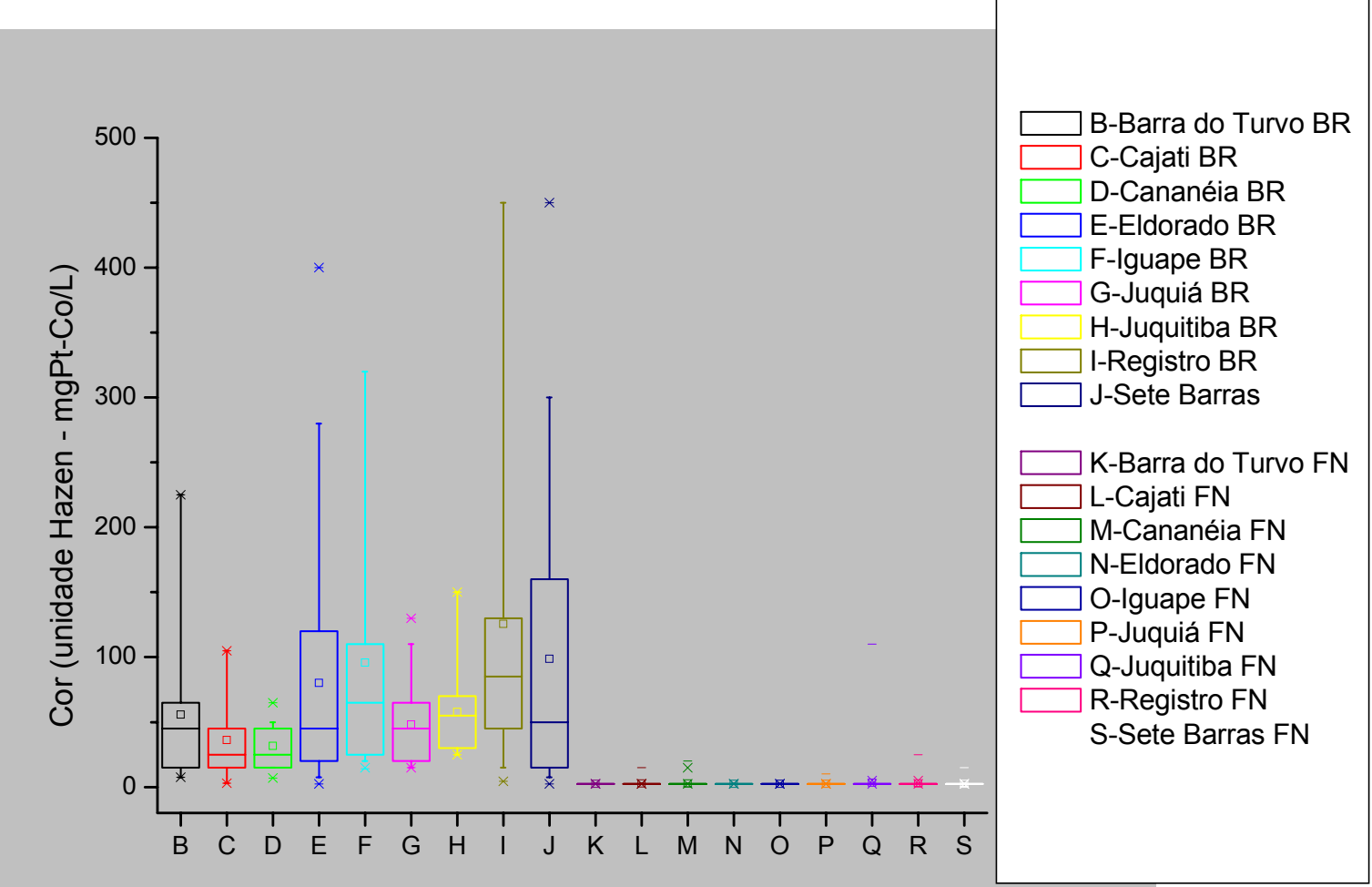

Identificação dos locais de coletas - $\mathrm{BR}=$ água superficial e $\mathrm{FN}=$ água tratada

FIGURA 30 - Índice de cor de água superficial e tratada por município

Na FIG.30 pode-se observar que a água tratada apresenta valores baixos para o parâmetro cor, sendo este de 2,5 para 99\% das medidas. Estes valores estão dentro do limite estabelecido da Portaria no 518/MS/04 $(5,0)$ com exceção do ponto máximo para Juquitiba FN. Quanto à água superficial os municípios que apresentaram maior variabilidade nos dados foram àqueles situados no Médio e Baixo Ribeira - Eldorado, Sete Barras, Registro e Iguape - e cuja captação é feita no Rio Ribeira de Iguape. A amplitude de variação da cor da água observada no Rio Ribeira de Iguape foi observada, principalmente, no período de chuvoso. 


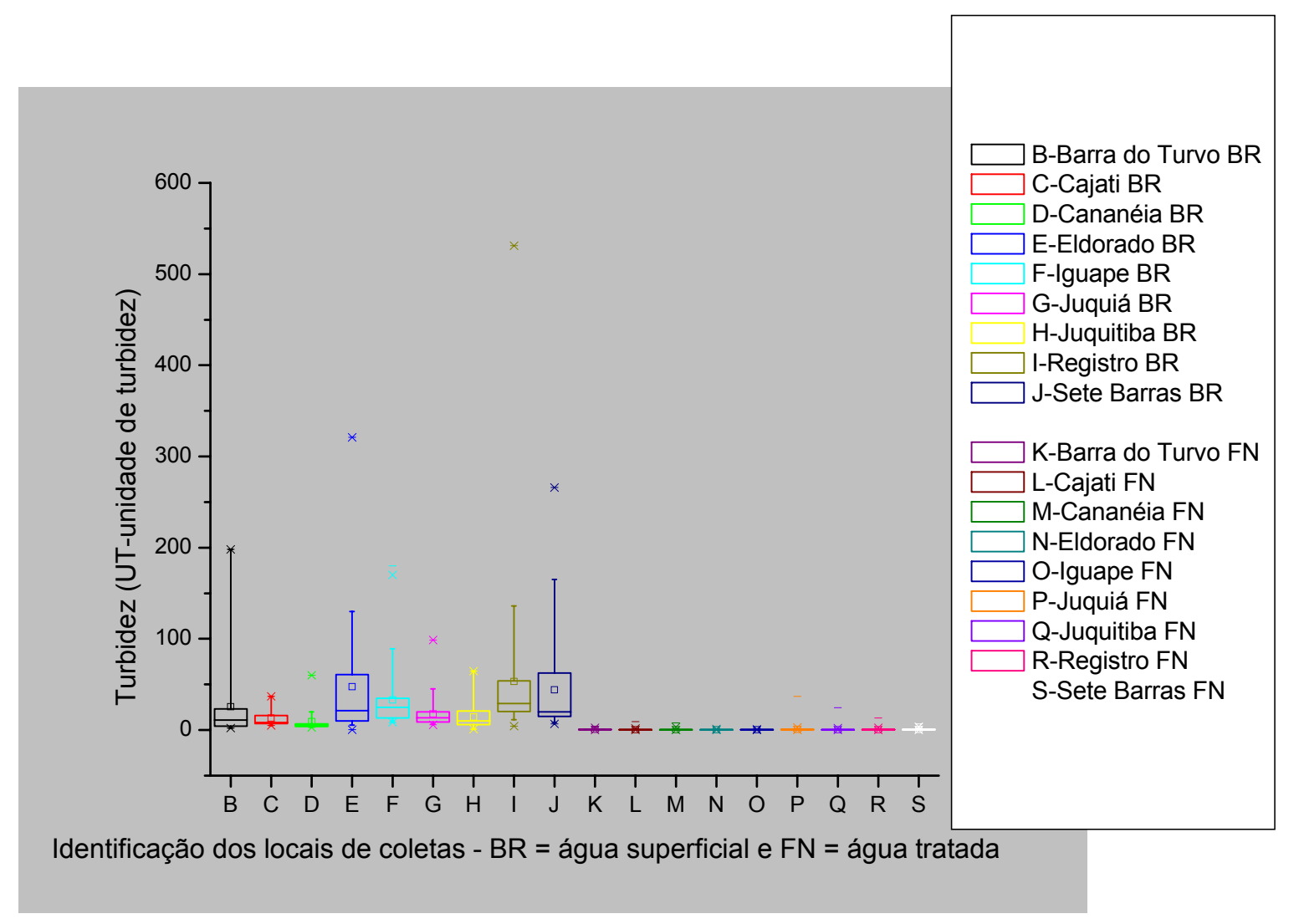

FIGURA 31 - Índice de turbidez de água superficial e tratada por município

Todos as amostras de água superficial avaliadas apresentam $75 \%$ dos valores de turbidez com valores $\leq 100$, em conformidade com a Resolução CONAMA no 20/86, para corpos d’água classe 2. Neste caso também os municípios do Médio e Baixo Ribeira apresentam maior variabilidade nos dados, principalmente, no período chuvoso.Cabe salientar que na região o mês de janeiro apresenta precipitações com média superior a 300mm (FIG.23), ocasionando grandes enchentes. Quanto os valores de água tratada quase todos apresentam valores de turbidez $<1,0$ de acordo com Portaria $n^{\circ}$ 518/MS/04 $(1,0)$, com exceção dos pontos máximos dos municípios de Juquitiba e Juquiá. 
6.5.1 Análise dos parâmetros físico-químicos das amostras de água superficial e tratada

As análises físico-químicas das amostras estudadas foram realizadas nos Laboratório de Controle Sanitário da SABESP de Registro. Os gráficos representados nas FIG.32, 33, 34, 35, 36 e 37 foram construídos com os valores obtidos nas análises destas amostras.

Nas FIG.32 e 33 estão representados os gráficos que relacionam o pH das amostras com as coletas, para as amostras de água superficial e tratada, respectivamente. Por meio dos gráficos observa-se que houve uma diminuição no $\mathrm{pH}$ das amostras dos períodos de chuva como fevereiro de 2003 e janeiro de 2004, principalmente nas amostras de água superficial.

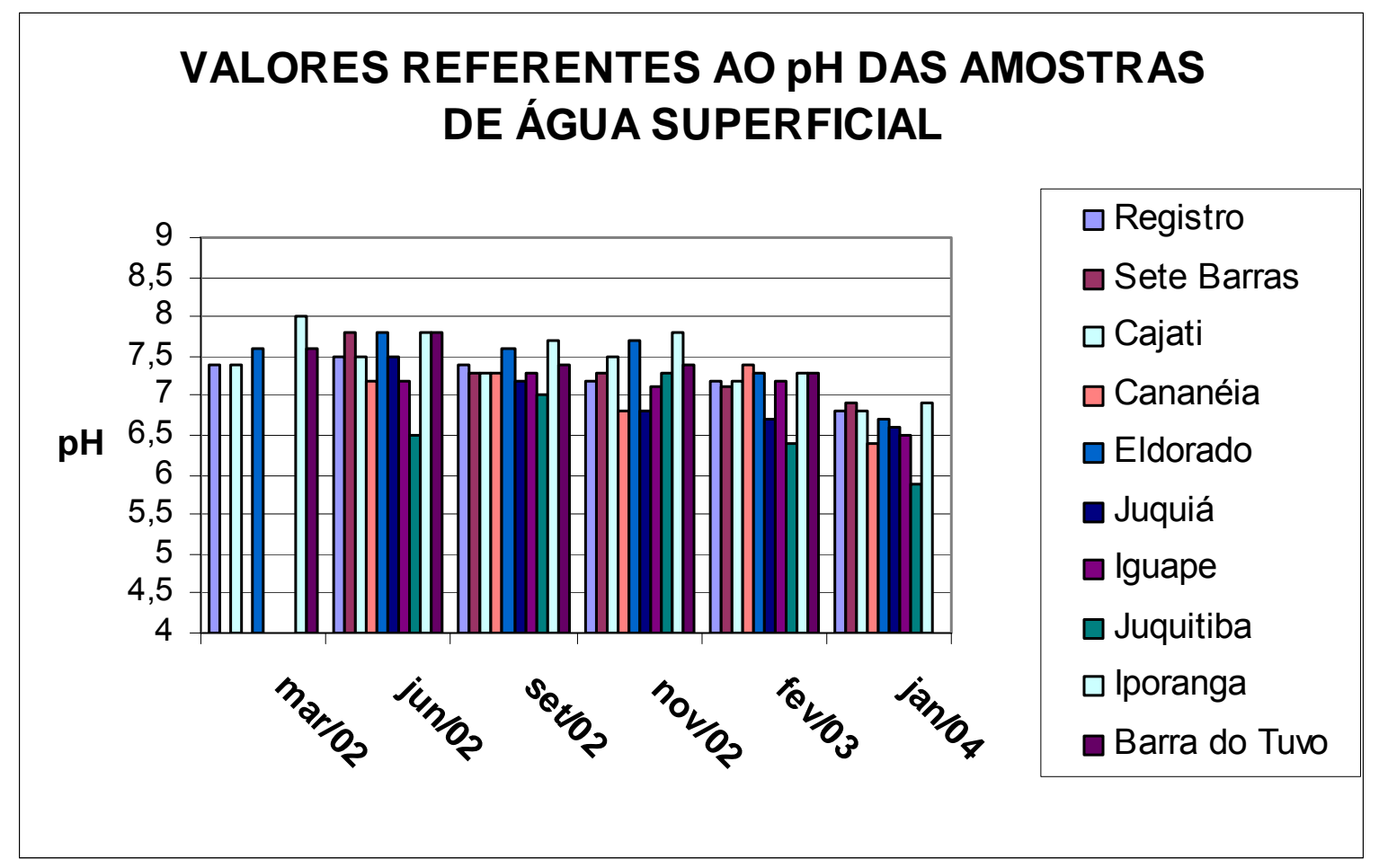

FIGURA 32 - Variação temporal e espacial dos valores de pH das amostras de água superficial 


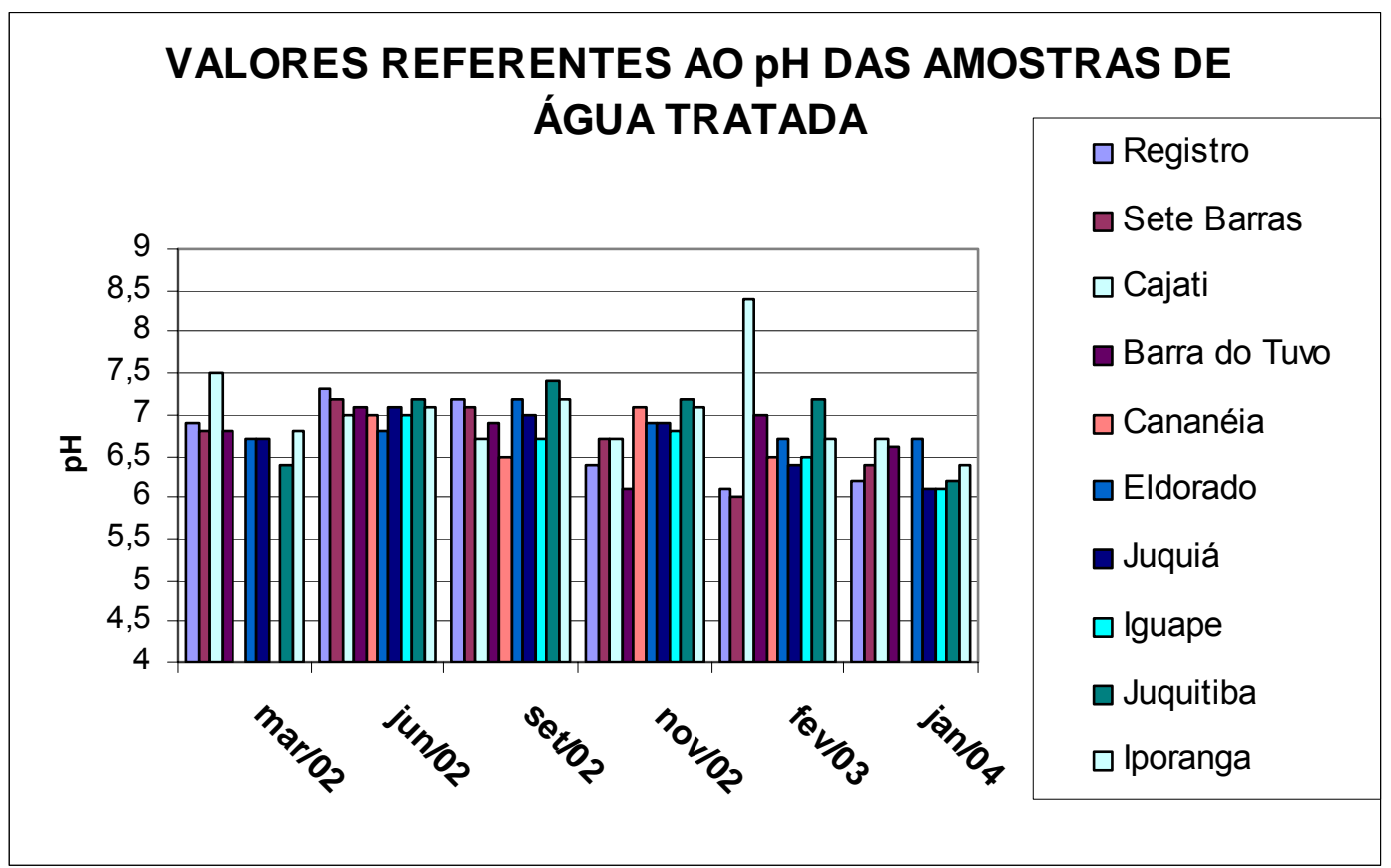

FIGURA 33 - Variação temporal e espacial dos valores de pH das amostras de água tratada

Na FIG.34 está representado o gráfico que relaciona a cor das amostras com as datas de coletas, para as amostras de água superficial. Conforme comentado anteriormente, e observado na FIG.34 as amostras de água superficial, no período de cheia, apresentam valores maiores para cor. Quanto à água tratada todos os valores obtidos foram $<5$.

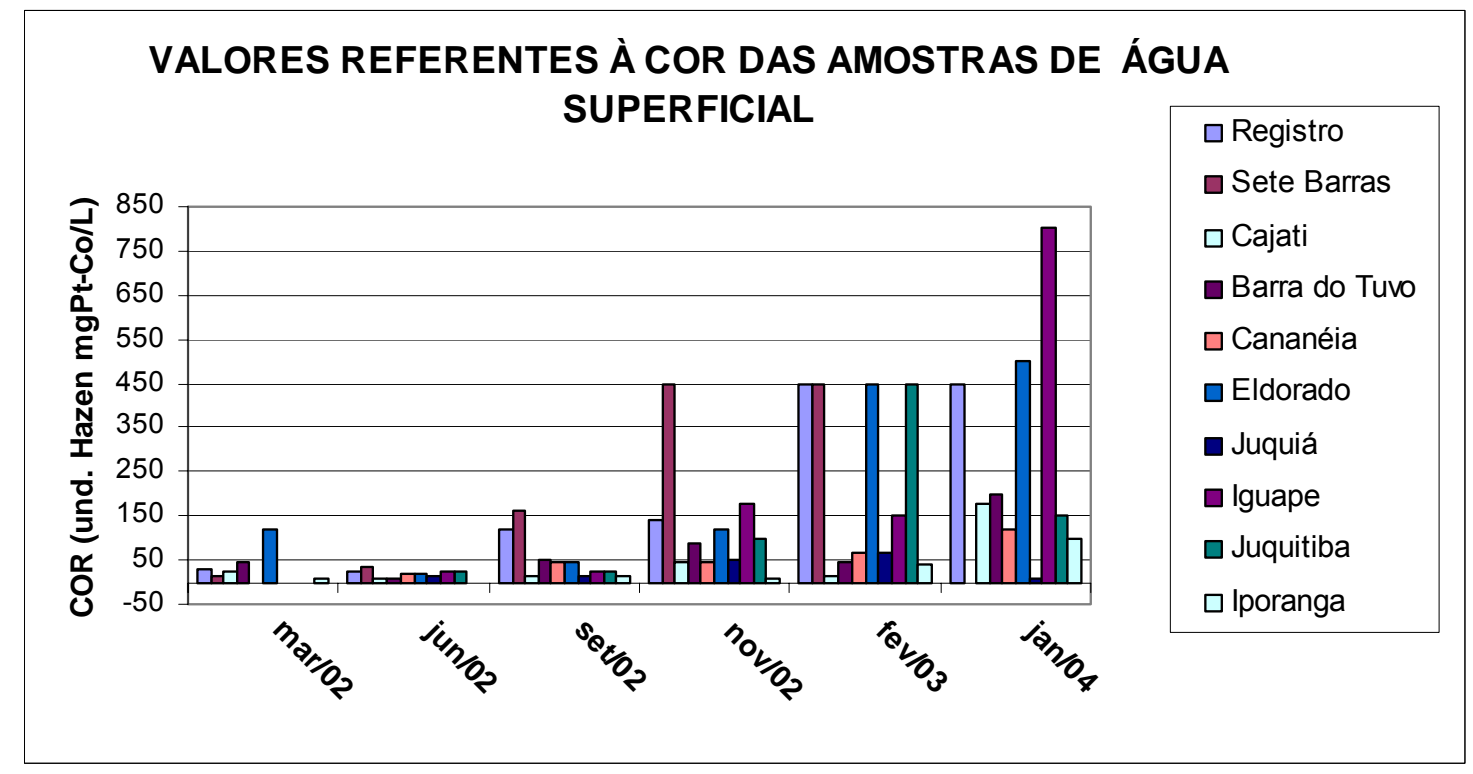

FIGURA 34 - Variação temporal e espacial dos valores da cor das amostras de água superficial 
Nas FIG.35 e 36 estão representados os gráficos que relacionam a turbidez das amostras com as datas de coletas, para as amostras de água superficial e tratada, respectivamente. Conforme comentado anteriormente, e observado na FIG.36 as amostras de água superficial, no período de chuva, apresentam valores maiores de turbidez.

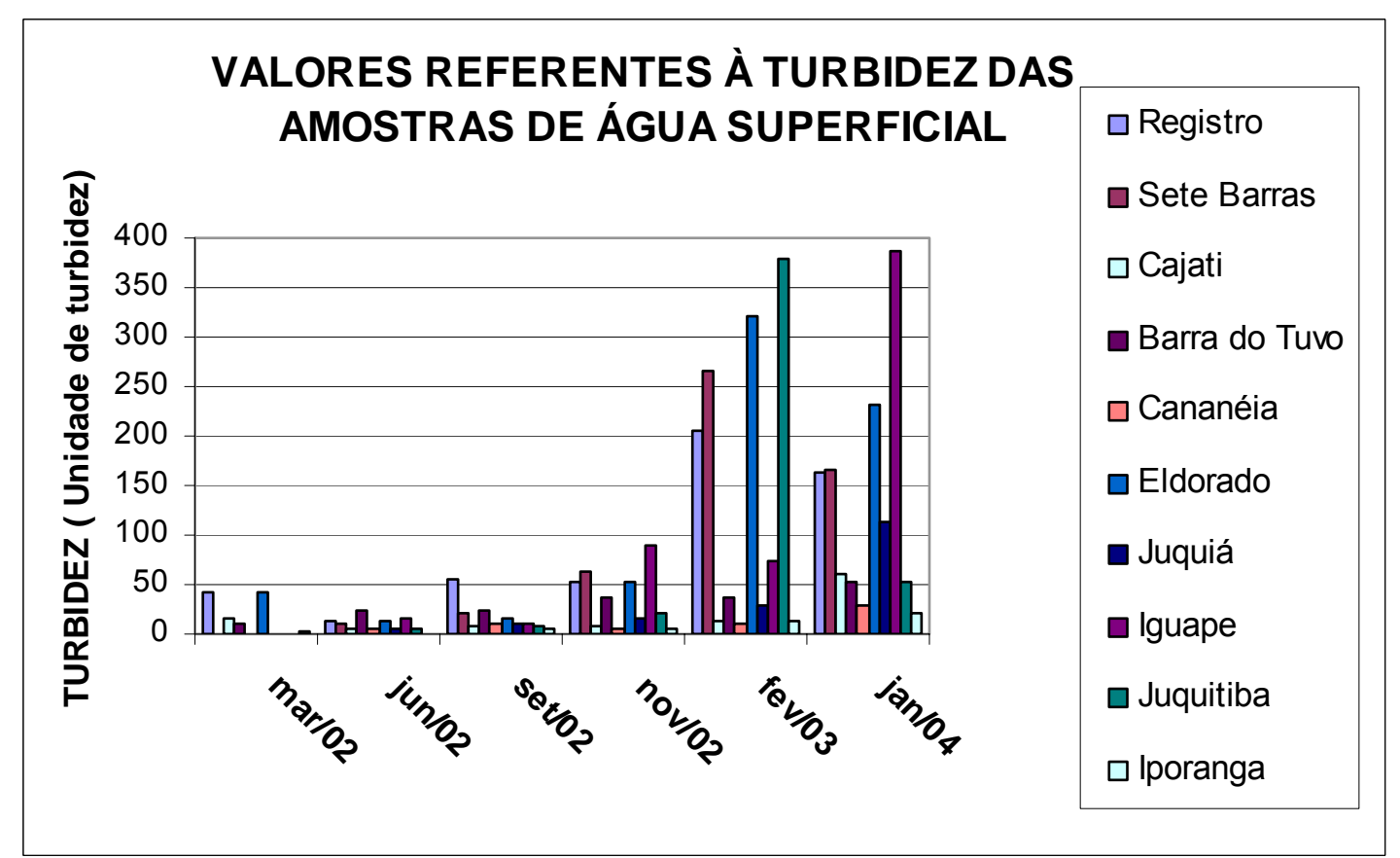

FIGURA 35 - Variação temporal e espacial dos valores da turbidez das amostras de água superficial

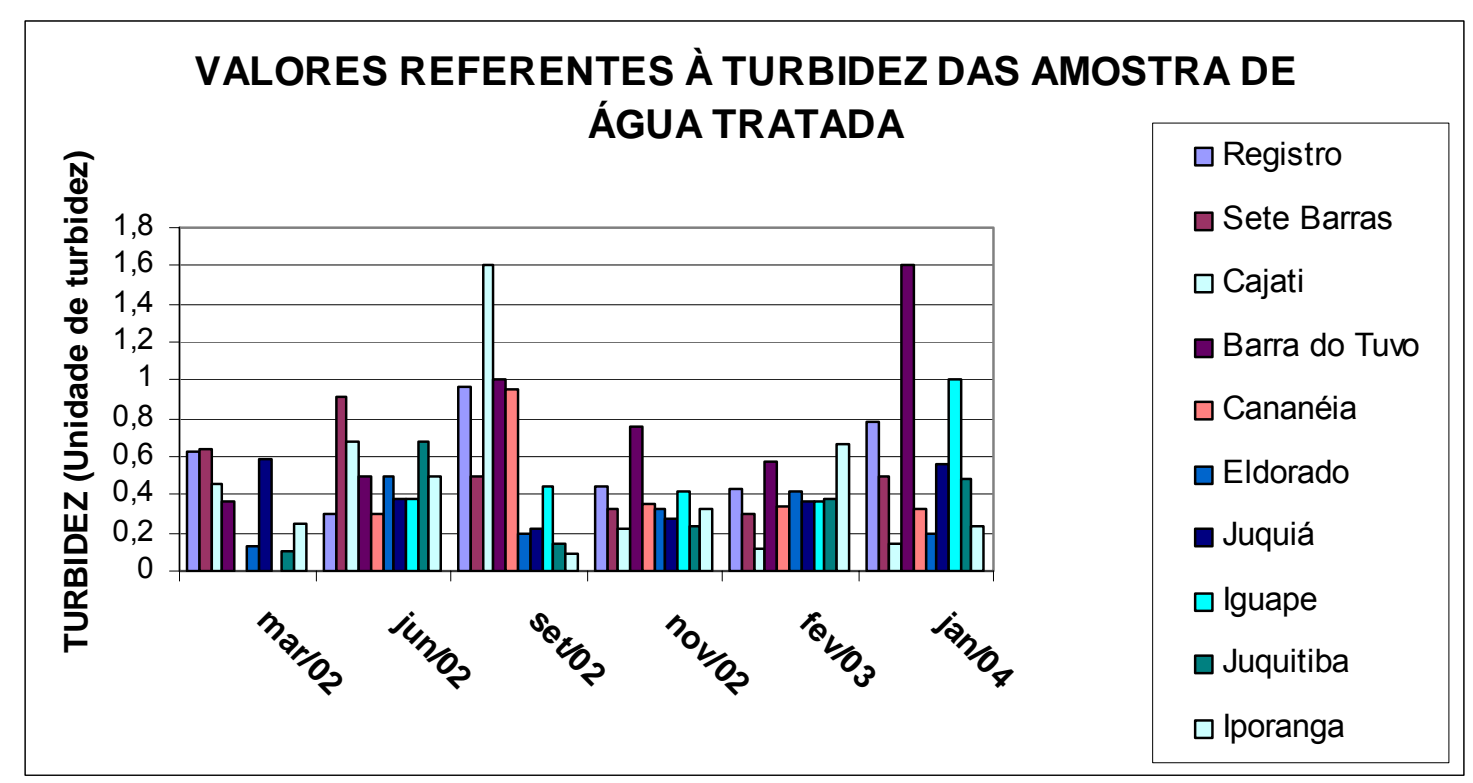

FIGURA 36 - Variação temporal e espacial dos valores da turbidez das amostras de água tratada 


\subsection{Análise dos resíduos de agrotóxicos em amostras de água superficial e tratada}

No APÊNDICE D são apresentados todos os resultados das análises de resíduos de agrotóxicos nas amostras de água superficial e tratada, no período de março de 2002 a fevereiro de 2003 e as amostras de janeiro de 2004, utilizando o método SPE - LC - UV/visível. Nas TAB.29 e 30 os resultados destas análises são apresentados de forma resumida.

Observa-se que das 76 amostras de água superficial analisadas, TAB.29, apenas uma (1) amostra de água superficial apresentou resíduo de aldicarbe, uma (1) apresentou resíduo de simazina, dezesseis (16) resíduo de carbofurano, uma (1) de atrazina e três (3) apresentaram resíduo de trifluralina.

Os resultados apresentados na TAB.30 mostram que apesar das concentrações encontradas serem extremamente baixas $\left(\mu \mathrm{gL}^{-1}\right)$ a água tratada também apresentou resíduos de agrotóxicos, pois das 76 amostras analisadas quatro (4) apresentaram resíduos de simazina, sete (7) de carbofurano, uma (1) de carabaril, duas (2) de atrazina e uma (1) de trifluralina.

O carbofurano foi encontrado em 23 amostras do total de 152 analisadas, entre água superficial e tratada, por SPE - LC - UV/visível, portanto, aproximadamente, $15 \%$ das amostras apresentaram resíduo de carbofurano. 0 resíduo de carbofurano o padrão de distribuição esperado, pois está entre os princípios ativos mais vendidos e aplicados na região de estudo. A análise preliminar do risco potencial de contaminação por pesticidas em águas superficiais e subterrâneas, discutida e apresentada no item 6.2, mostrou que dos pesticidas estudados o carbofurano, por ter elevada meia-vida em água $\left(\mathrm{DT}_{50}=\right.$ 121 em $\mathrm{pH} 7$ ), apresentou uma grande probabilidade de contaminação da água superficial. 
TABELA 29 - Ocorrência de resíduos de agrotóxicos em $\mu \mathrm{gL}^{-1}$ nas amostras de água superficial da Bacia Hidrográfica do rio Ribeira de Iguape, durante o período de março/2002 a fevereiro/2003 e em janeiro/2004.

\begin{tabular}{|c|c|c|c|c|c|c|c|c|c|c|c|c|c|}
\hline \multirow{2}{*}{ Localidade } & & \multicolumn{2}{|l|}{ Aldicarbe } & \multicolumn{2}{|l|}{ Simazina } & \multicolumn{2}{|c|}{ Carbofurano } & \multicolumn{2}{|l|}{ Carbaril } & \multicolumn{2}{|l|}{ Atrazina } & \multicolumn{2}{|c|}{ Trifluralina } \\
\hline & & Min - máx & Fq. & min - máx & $\mathrm{Fq}$. & min - máx & Fq. & min - máx & Fq. & min - máx & Fq. & min - máx & Fq. \\
\hline Registro & 6 & $<0,17$ & n.d. & $<0,01$ & n.d. & $<0,12-0,32$ & 1 & $<0,01$ & n.d. & $<0,02$ & n.d. & $<0,10$ & n.d. \\
\hline Sete Barras & 6 & $<0,17$ & n.d. & $<0,01$ & n.d. & $<0,12-0,24$ & 2. & $<0,01$ & n.d. & $<0,02$ & n.d. & $<0,10$ & n.d. \\
\hline Jacupiranga & 2 & $<0,17$ & n.d. & $<0,01$ & n.d. & $<0,12$ & n.d. & $<0,01$ & n.d. & $<0,02$ & n.d. & $<0,10$ & n.d. \\
\hline Cajati & 6 & $<0,17$ & n.d. & $<0,01$ & n.d. & $<0,12$ & n.d. & $<0,01$ & n.d. & $<0,02$ & n.d. & $<0,10$ & n.d. \\
\hline Barra do Turvo & 6 & $<0,17$ & n.d. & $<0,01$ & n.d. & $<0,12-0,62$ & 1 & $<0,01$ & n.d. & $<0,02$ & n.d. & $<0,10$ & n.d. \\
\hline Cananéia & 6 & $<0,17$ & n.d. & $<0,01$ & n.d. & $<0,12-0,52$ & 2 & $<0,01$ & n.d. & $<0,02$ & n.d. & $<0,10-1,73$ & 1 \\
\hline Eldorado & 6 & $<0,17$ & n.d. & $<0,01$ & n.d. & $<0,12-0,56$ & 3 & $<0,01$ & n.d. & $<0,02$ & n.d. & $<0,10$ & n.d. \\
\hline Pariquera Açu & 2 & $<0,17$ & n.d. & $<0,01$ & n.d. & $<0,10-0,15$ & 1 & $<0,01$ & n.d. & $<0,02$ & n.d. & $<0,10-0,97$ & 1 \\
\hline Juquiá & 6 & $<0,17-2,15$ & 1 & $<0,01$ & n.d. & $<0,12$ & n.d. & $<0,01$ & n.d. & $<0,02-0,06$ & 1 & $<0,10$ & n.d. \\
\hline Miracatu & 2 & $<0,17$ & n.d. & $<0,01$ & n.d. & $<0,12$ & n.d. & $<0,01$ & n.d. & $<0,02$ & n.d. & $<0,10$ & n.d. \\
\hline Iguape & 6 & $<0,17$ & n.d. & $<0,01$ & n.d. & $<0,12-0,50$ & 3 & $<0,01$ & n.d. & $<0,02$ & n.d. & $<0,10$ & n.d. \\
\hline Itariri & 2 & $<0,17$ & n.d. & $<0,01$ & n.d. & $<0,12$ & n.d. & $<0,01$ & n.d. & $<0,02$ & n.d. & $<0,10$ & n.d. \\
\hline Pedro de Toledo & 2 & $<0,17$ & n.d. & $<0,01$ & n.d. & $<0,12$ & n.d. & $<0,01$ & n.d. & $<0,02$ & n.d. & $<0,10$ & n.d. \\
\hline Juquitiba & 6 & $<0,17$ & n.d. & $<0,01-0,03$ & 1 & $<0,12-0,31$ & 1 & $<0,01$ & n.d. & $<0,02$ & n.d. & $<0,10-0,59$ & 1 \\
\hline $\begin{array}{l}\text { S. Lourenço da } \\
\text { Serra }\end{array}$ & 2 & $<0,17$ & n.d. & $<0,01$ & n.d. & $<0,12$ & n.d. & $<0,01$ & n.d. & $<0,02$ & n.d. & $<0,10$ & n.d. \\
\hline Paiol do Meio & 2 & $<0,17$ & n.d. & $<0,01$ & n.d. & $<0,12$ & n.d. & $<0,01$ & n.d. & $<0,02$ & n.d. & $<0,10$ & n.d. \\
\hline Iporanga & 6 & $<0,17$ & n.d. & $<0,01$ & n.d. & $<0,12-0,11$ & 2 & $<0,01$ & n.d. & $<0,02$ & n.d. & $<0,10$ & n.d. \\
\hline Tapirai & 2 & $<0,17$ & n.d. & $<0,01$ & n.d. & $<0,12$ & n.d. & $<0,01$ & n.d. & $<0,02$ & n.d. & $<0,10$ & n.d. \\
\hline
\end{tabular}

$\mathrm{n}=$ número de amostras; $\mathrm{Fq} .=$ freqüência 
TABELA 30 - Ocorrência de resíduos de agrotóxicos em $\mu \mathrm{gL}^{-1}$ nas amostras de água tratada da Bacia Hidrográfica do rio Ribeira de Iguape, durante o período de março/2002 a fevereiro/2003 e em janeiro/2004.

\begin{tabular}{|c|c|c|c|c|c|c|c|c|c|c|c|c|c|}
\hline \multirow{2}{*}{ Localidade } & & \multicolumn{2}{|c|}{ Aldicarbe } & \multicolumn{2}{|l|}{ Simazina } & \multicolumn{2}{|c|}{ Carbofurano } & \multicolumn{2}{|l|}{ Carbaril } & \multicolumn{2}{|l|}{ Atrazina } & \multicolumn{2}{|c|}{ Trifluralina } \\
\hline & & Min - máx & Fq. & min - máx & $\mathrm{Fq}$. & min - máx & Fq. & min - máx & Fq. & min - máx & Fq. & min - máx & Fq. \\
\hline Registro & 6 & $<0,17$ & n.d. & $<0,01$ & n.d. & $<0,12$ & n.d. & $<0,01$ & n.d. & $<0,02$ & n.d. & $<0,10$ & n.d. \\
\hline Sete Barras & 6 & $<0,17$ & n.d. & $<0,01-0,26$ & 2 & $<0,12$ & n.d. & $<0,01-0,92$ & 1 & $<0,02$ & n.d. & $<0,10$ & n.d. \\
\hline Jacupiranga & 2 & $<0,17$ & n.d. & $<0,01$ & n.d. & $<0,12$ & n.d. & $<0,01$ & n.d. & $<0,02$ & n.d. & $<0,10$ & n.d. \\
\hline Cajati & 6 & $<0,17$ & n.d. & $<0,01$ & n.d. & $<0,12-0,11$ & 2 & $<0,01$ & n.d. & $<0,02$ & n.d. & $<0,10$ & n.d. \\
\hline Barra do Turvo & 6 & $<0,17$ & n.d. & $<0,01$ & n.d. & $<0,12$ & n.d. & $<0,01$ & n.d. & $<0,02$ & n.d. & $<0,10$ & n.d. \\
\hline Cananéia & 6 & $<0,17$ & n.d. & $<0,01$ & n.d. & $<0,12-2,24$ & 1 & $<0,01$ & n.d. & $<0,02$ & n.d. & $<0,10$ & n.d. \\
\hline Eldorado & 6 & $<0,17$ & n.d. & $<0,01$ & n.d. & $<0,12$ & n.d. & $<0,01$ & n.d. & $<0,02$ & n.d. & $<0,10$ & n.d. \\
\hline Pariquera Açu & 2 & $<0,17$ & n.d. & $<0,01$ & n.d. & $<0,12$ & n.d. & $<0,01$ & n.d. & $<0,02$ & n.d. & $<0,10$ & n.d. \\
\hline Juquiá & 6 & $<0,17$ & n.d. & $<0,01$ & n.d. & $<0,12$ & n.d. & $<0,01$ & n.d. & $<0,02$ & n.d & $<0,10$ & n.d. \\
\hline Miracatu & 2 & $<0,17$ & n.d. & $<0,01$ & n.d. & $<0,12$ & n.d. & $<0,01$ & n.d. & $<0,02$ & n.d. & $<0,10$ & n.d. \\
\hline Iguape & 6 & $<0,17$ & n.d. & $<0,01-0,02$ & 1 & $<0,12-0,66$ & 1 & $<0,01$ & n.d. & $<0,02-0.22$ & 2 & $<0,10$ & n.d. \\
\hline Itariri & 2 & $<0,17$ & n.d. & $<0,01$ & n.d. & $<0,12$ & n.d. & $<0,01$ & n.d. & $<0,02$ & n.d. & $<0,10$ & n.d. \\
\hline Pedro de Toledo & 2 & $<0,17$ & n.d. & $<0,01$ & n.d. & $<0,12$ & n.d. & $<0,01$ & n.d. & $<0,02$ & n.d. & $<0,10$ & n.d. \\
\hline Juquitiba & 6 & $<0,17$ & n.d. & $<0,01-0,03$ & 1 & $<0,12-0,65$ & 1 & $<0,01$ & n.d. & $<0,02$ & n.d. & $<0,10-2,06$ & 1 \\
\hline $\begin{array}{l}\text { S. Lourenço da } \\
\text { Serra }\end{array}$ & 2 & $<0,17$ & n.d. & $<0,01$ & n.d. & $<0,12$ & n.d. & $<0,01$ & n.d. & $<0,02$ & n.d. & $<0,10$ & n.d. \\
\hline Paiol do Meio & 2 & $<0,17$ & n.d. & $<0,01$ & n.d. & $<0,12$ & n.d. & $<0,01$ & n.d. & $<0,02$ & n.d. & $<0,10$ & n.d. \\
\hline Iporanga & 6 & $<0,17$ & n.d. & $<0,01$ & n.d. & $<0,12-0,23$ & 2 & $<0,01$ & n.d. & $<0,02$ & n.d. & $<0,10$ & n.d. \\
\hline Tapirai & 2 & $<0,17$ & n.d. & $<0,01$ & n.d. & $<0,12$ & n.d. & $<0,01$ & n.d. & $<0,02$ & n.d. & $<0,10$ & n.d. \\
\hline
\end{tabular}

$\mathrm{n}=$ número de amostras; $\mathrm{Fq}$. = freqüência 
Dos pontos de coleta estudados, as áreas de captação pertencentes aos municípios de Iguape, Juquitiba, Iporanga e Sete Barras foram os pontos que apresentaram os maiores números de amostras positivas (ou impactadas), sendo um total de sete (7), seis (6), cinco (5) e quatro (4) amostras respectivamente, das doze (12) amostras analisadas de cada ponto.

O ponto de captação da ETA de Iguape fica próximo ao desemboque do rio Ribeira de Iguape no mar, o que indica que neste ponto o rio apresenta contribuição de toda a sua carga tributária, desde a nascente até a foz. $\mathrm{O}$ rio Ribeira de Iguape apresenta cultura de bananas ao longo de quase toda margem, conforme se observou nas cidades de Eldorado, Sete Barras e Registro, durante as visitas a região (fotos do APÊNDICE C). Explicando a maior freqüência de amostras contaminadas nas regiões de Iguape e Sete Barras.

Juquitiba apresentou grande impacto relativo ao uso do solo pela agricultura, essa influência se deve principalmente pela proximidade de unidades com alta atividade agrícola como Sorocaba, localizada na bacia do Médio e Alto Tietê, região de intensa atividade agrícola.

A captação da ETA de Iporanga é feita no rio Iporanga, embora, sua nascente fique em Apiaí, o rio percorre grande parte dentro do Parque Estadual do Alto do Ribeira - PETAR, que apesar de Área de Proteção Ambiental (APA) existem culturas de tomate e pêssego próximo a nascente (Molander, 1998) o que provavelmente pode ter causado a grande incidência de amostras positivas.

Na FIG.37 é apresentada uma representação esquemática dos pontos de coletas e das principais fontes de poluição quanto ao uso e ocupação do solo.

Os gráficos apresentados nas FIG.38 (a) e (b) indicam: (a) os números de amostras as quais foram detectados resíduos de agrotóxicos por compostos e (b) a porcentagem dos compostos por número total de amostras analisada. 


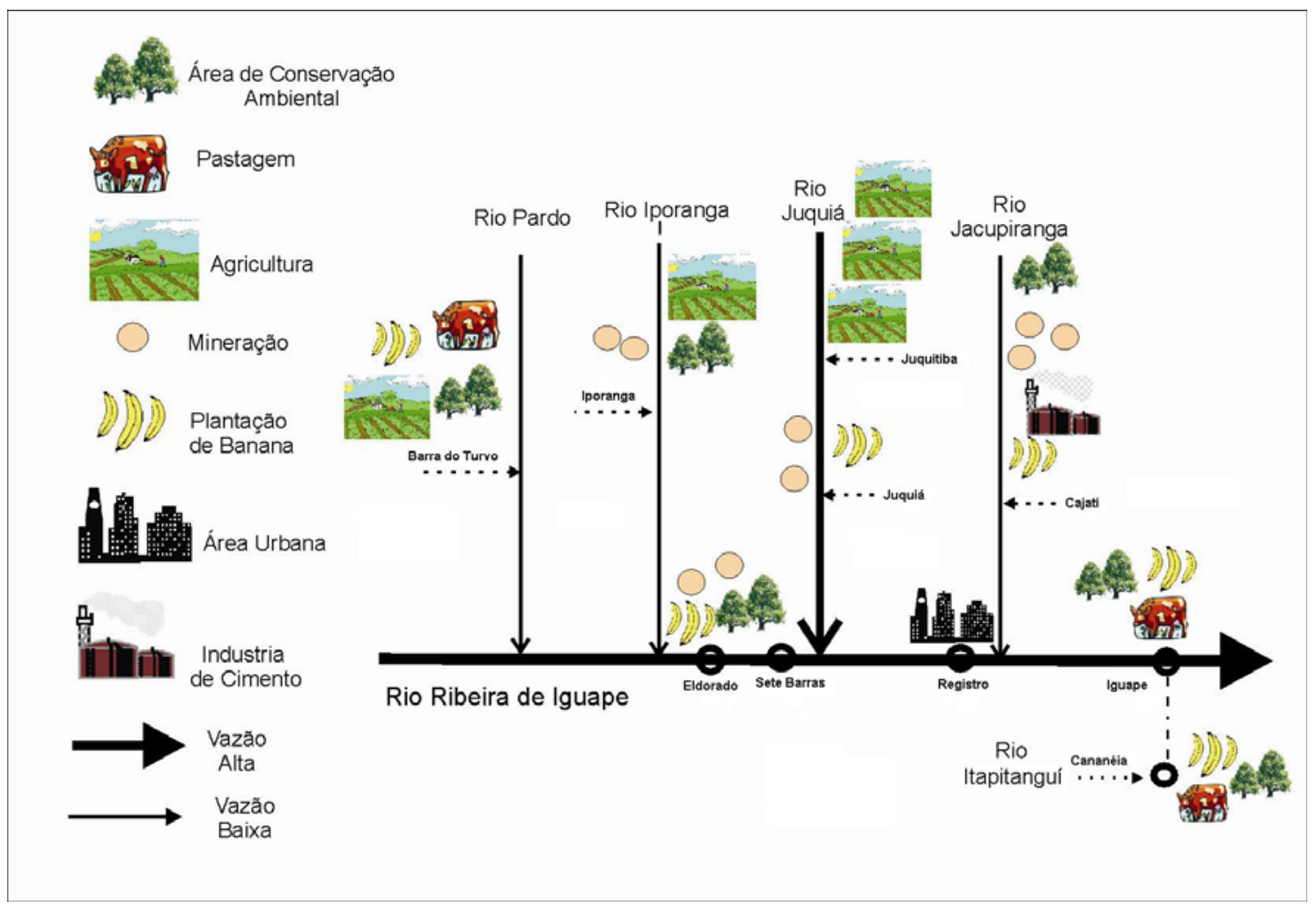

FIGURA 37 - Representação esquemática dos pontos de coleta e do uso e ocupação do solo identificando as principais fontes de poluição da Bacia Hidrográfica do Rio Ribeira de Iguape.

Na TAB.31 são apresentados os resultados das análises de resíduos de agrotóxicos obtidos por SPE -LC - MS/MS, nas amostras coletadas em janeiro de 2004. Por se tratar de uma detecção muito mais sensível e seletiva que a detecção por UV/visível, foi possível confirmar e quantificar a presença de resíduos de agrotóxicos nas amostras de água analisadas na ordem de $\mathrm{ngL}^{-1}$.

Devido a esta grande sensibilidade, o carbofurano foi detectado em todas as amostras tanto em água bruta como tratada. Em três (3) amostras de água tratada (Registro, Juquiá e Iguape) registrou-se a presença de um dos seus produtos de degradação o 3-hidroxi-carbofurano. Das vinte (20) amostras analisadas doze (12) apresentaram resíduos de carbaril, dezessete (17) de atrazina, cinco (5) de simazina e três (3) de trifluralina. 


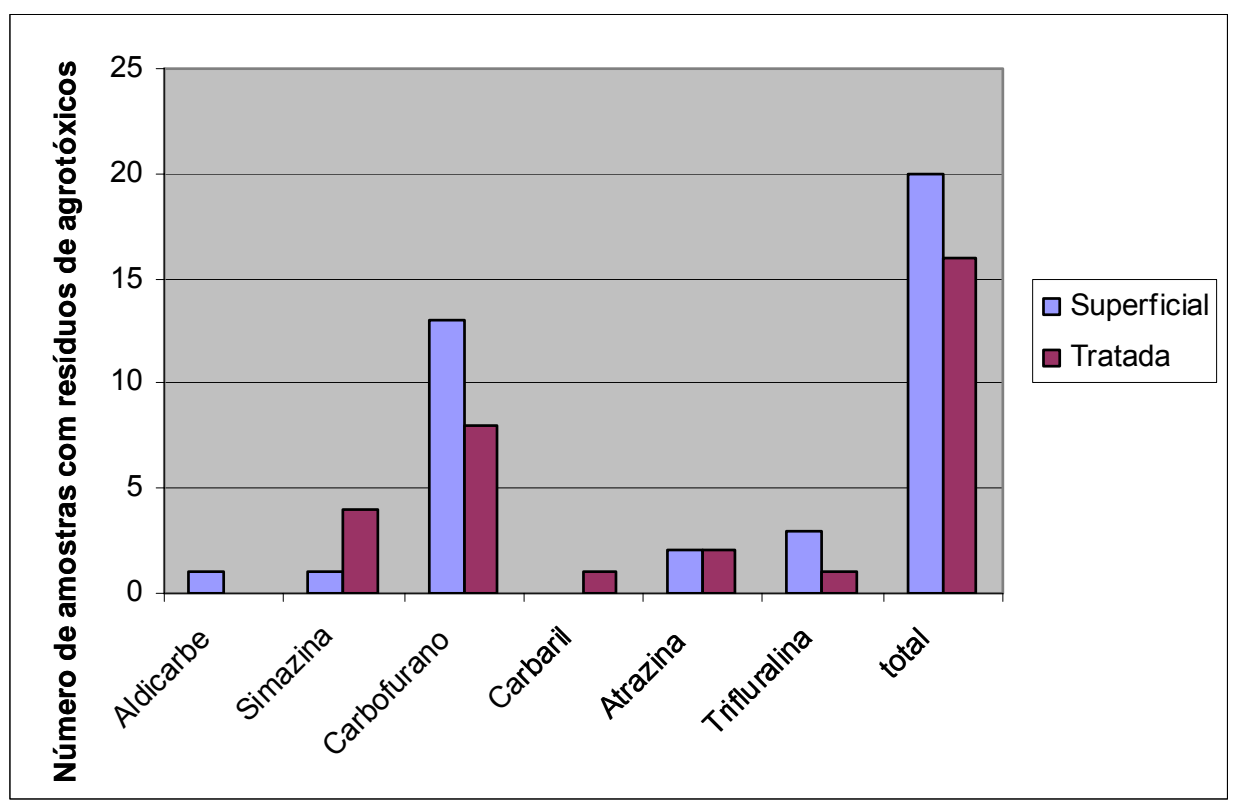

(a)

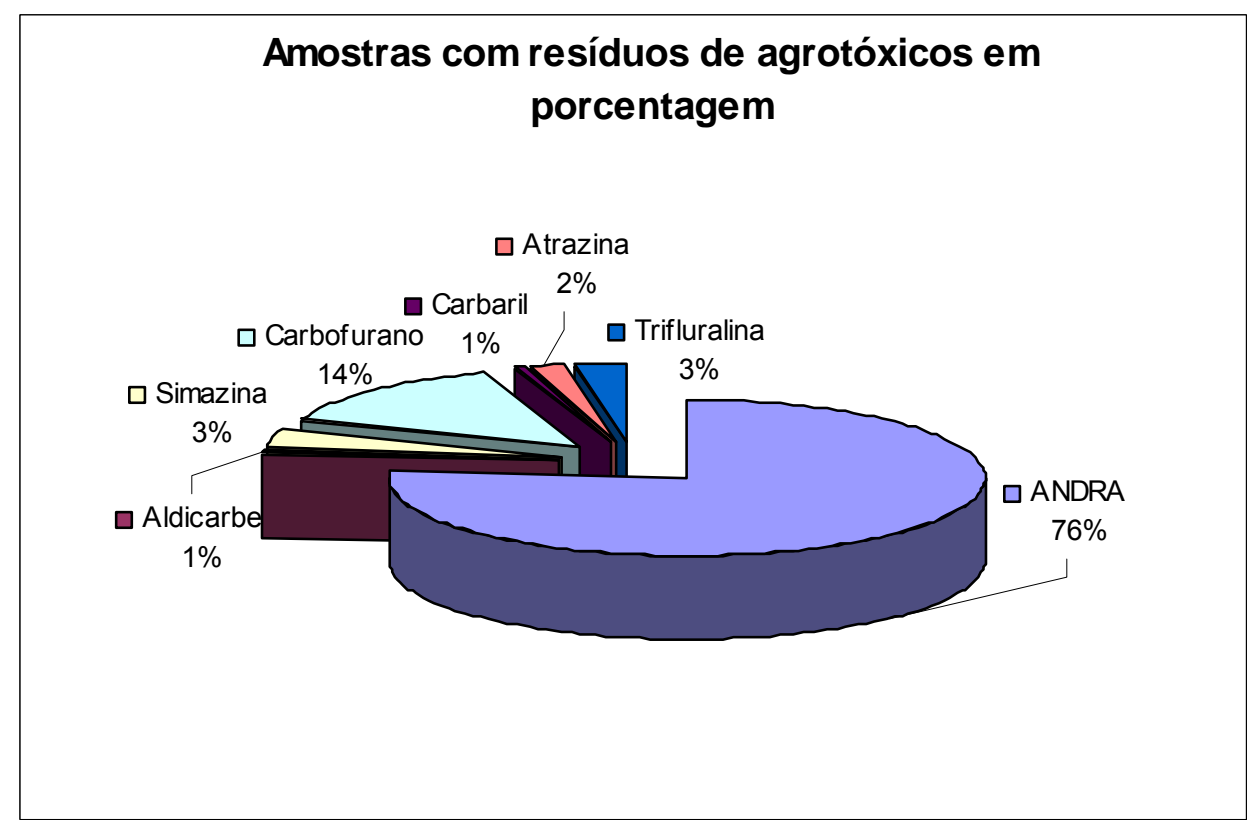

(b)

ANDRA = amostras onde não foram detectados resíduos de agrotóxicos .

FIGURA 38 - Gráficos da porcentagem de amostras que apresentaram resposta positiva na identificação e quantificação dos agrotóxicos analisados. 
TABELA 31 - Resultado da determinação de resíduos de agrotóxicos em amostras de água superficial (BR) e tratada (FN), pertencentes à Região do Vale do Ribeira analisadas por SPE - LC - MS/MS, janeiro de 2004.

\begin{tabular}{|c|c|c|c|c|c|c|c|c|c|c|c|}
\hline 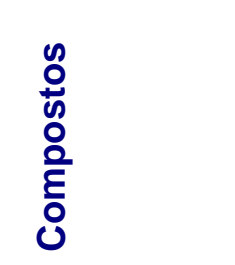 & 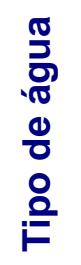 & 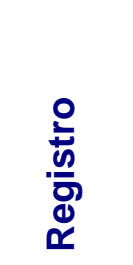 & 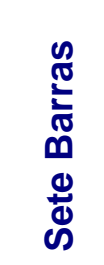 & 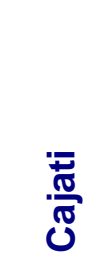 & 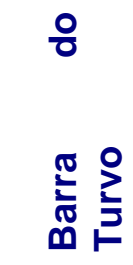 & 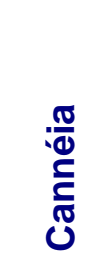 & $\begin{array}{l}\frac{0}{0} \\
\frac{\pi}{4} \\
\frac{0}{0} \\
\frac{0}{\amalg}\end{array}$ & $\frac{\sqrt[\pi]{\pi}}{\frac{\pi}{0}}$ & $\frac{0}{\frac{0}{0}}$ & 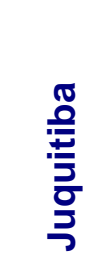 & 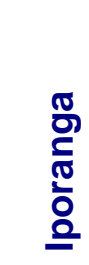 \\
\hline \multirow{2}{*}{$\begin{array}{l}\text { Aldicarbe } \\
{\left[\mathrm{ngL}^{-1}\right]}\end{array}$} & $\mathrm{BR}$ & n.d. & n.d. & n.d. & n.d. & n.d. & n.d. & n.d. & n.d. & n.d. & n.d. \\
\hline & FN & n.d. & n.d. & n.d. & n.d. & n.d. & n.d. & n.d. & n.d. & n.d. & n.d. \\
\hline \multirow{2}{*}{$\underset{\left[\mathrm{ngL}^{-1}\right]}{\text { Simazina }}$} & $\mathrm{BR}$ & n.d. & n.d. & n.d. & n.d. & n.d. & n.d. & n.d. & n.d. & n.d. & n.d. \\
\hline & $\mathrm{FN}$ & n.d. & n.d. & n.d. & 1,31 & n.d. & 1,41 & n.d. & 2,12 & 1,62 & 3,64 \\
\hline \multirow{2}{*}{$\begin{array}{c}\text { Carbofurano } \\
{\left[\mathrm{ngL}^{-1}\right]}\end{array}$} & $\mathrm{BR}$ & 16,90 & 8,56 & 1,14 & 0,15 & 0,40 & 0,87 & 14,10 & 15,10 & 0,11 & 0,08 \\
\hline & $\mathrm{FN}$ & 2,13 & 2,77 & 0,47 & 0,95 & 0,27 & 1,69 & 5,27 & 8,38 & 1,39 & 2,90 \\
\hline \multirow{2}{*}{$\begin{array}{c}\text { Carbaril } \\
{\left[\mathrm{ngL}^{-1}\right]}\end{array}$} & BR & 2,69 & 1,53 & 0,80 & 0,13 & n.d. & 0,30 & 0,98 & 2,87 & n.d. & n.d. \\
\hline & $\mathrm{FN}$ & n.d. & n.d. & n.d. & 0,80 & n.d. & 0,67 & n.d. & 2,33 & 0,73 & 2,22 \\
\hline \multirow{2}{*}{$\begin{array}{c}\text { Atrazina } \\
{\left[\mathrm{ngL}^{-1}\right]}\end{array}$} & BR & 1,04 & 1,39 & 0,20 & 0,37 & n.d. & 3,35 & 0,79 & 1,18 & 0,68 & 0,22 \\
\hline & $\mathrm{FN}$ & 0,38 & 0,61 & n.d. & 3,41 & n.d. & 4,98 & 0,40 & 4,41 & 4,29 & 7,55 \\
\hline \multirow{2}{*}{$\begin{array}{c}\text { Trifluralina } \\
{\left[\mathrm{ngL}^{-1}\right]}\end{array}$} & BR & n.d. & n.d. & n.d. & n.d. & n.d. & n.d. & n.d. & n.d. & n.d. & n.d. \\
\hline & $\mathrm{FN}$ & n.d. & n.d. & n.d. & n.d. & n.d. & n.d. & n.d. & $\phi$ & $\phi$ & $\phi$ \\
\hline \multirow{2}{*}{$\begin{array}{l}\text { Aldicarbe } \\
\text { sulfona } \\
{\left[\mathrm{ngL}^{-1}\right]}\end{array}$} & BR & n.d. & n.d. & n.d. & n.d. & n.d. & n.d. & n.d. & n.d. & n.d. & n.d. \\
\hline & $\mathrm{FN}$ & n.d. & n.d. & n.d. & n.d. & n.d. & n.d. & n.d. & n.d. & n.d. & n.d. \\
\hline \multirow{2}{*}{$\begin{array}{l}\text { Metomil } \\
{\left[\mathrm{ngL}^{-1}\right]}\end{array}$} & BR & n.d. & n.d. & n.d. & n.d. & n.d. & n.d. & n.d. & n.d. & n.d. & n.d. \\
\hline & $\mathrm{FN}$ & n.d. & n.d. & n.d. & n.d. & n.d. & n.d. & n.d. & n.d. & n.d. & n.d. \\
\hline \multirow{2}{*}{$\begin{array}{c}\text { 3-Hidróxi- } \\
\text { carbofurano } \\
{\left[\mathrm{ngL}^{-1}\right]}\end{array}$} & $\mathrm{BR}$ & n.d. & n.d. & n.d. & n.d. & n.d. & n.d. & n.d. & n.d. & n.d. & n.d. \\
\hline & $\mathrm{FN}$ & $\phi$ & n.d. & n.d. & n.d. & n.d. & n.d. & $\phi$ & $\phi$ & n.d. & n.d. \\
\hline
\end{tabular}


Do total das amostras analisadas: $76 \%$ não apresentaram resíduos de agrotóxicos, $14 \%$ apresentaram resíduos de carbofurano, 3\% de trifluralina, $2 \%$ de atrazina e $3 \%$ de simazina. As amostras provenientes das coletas de Iguape foram as que apresentaram maior incidência de resíduos de agrotóxicos, seguidas pelas amostras de Eldorado, Barra do Turvo e Iporanga. Estes resultados mostram que, embora as concentrações encontradas sejam extremamente baixas, da ordem de $\mathrm{ngL}^{-1}$, não comprometendo a qualidade da água da Bacia para consumo o humano, esta já apresenta indícios de contaminação pelo uso de agrotóxico na região, principalmente provenientes das plantações de banana.

Como previsto no estudo de lixiviação o alto índice pluviométrico apresentou grande influencia no carreamento dos agrotóxicos para os rios da Bacia, pois houve maior incidência de amostras positiva no período de cheia como mostra os gráficos apresentados nas FIG.39, 40 e 41.

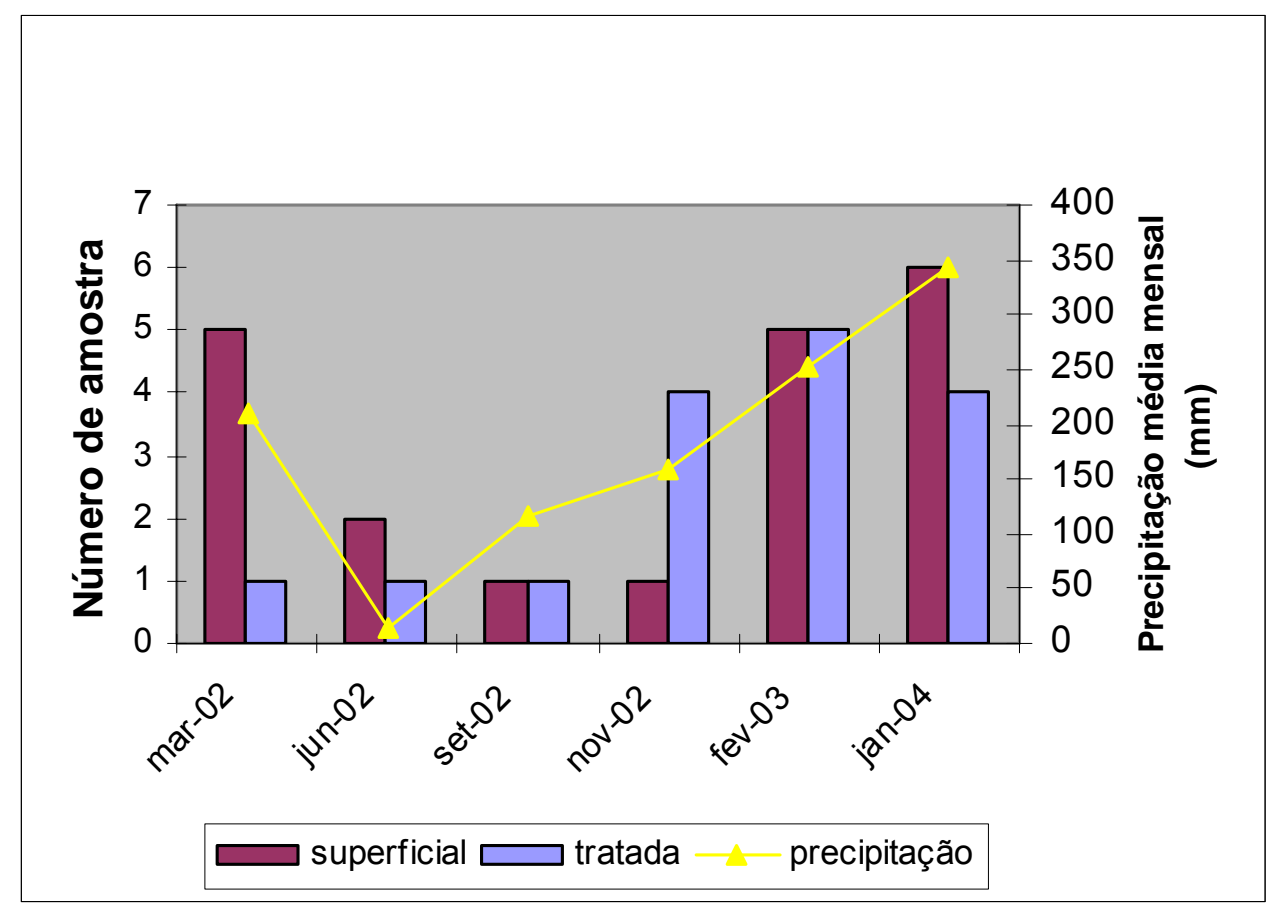

FIGURA 39 - Gráfico comparativo de intensidade pluviométrica e o número de amostras positivas para resíduos dos agrotóxicos estudados. 

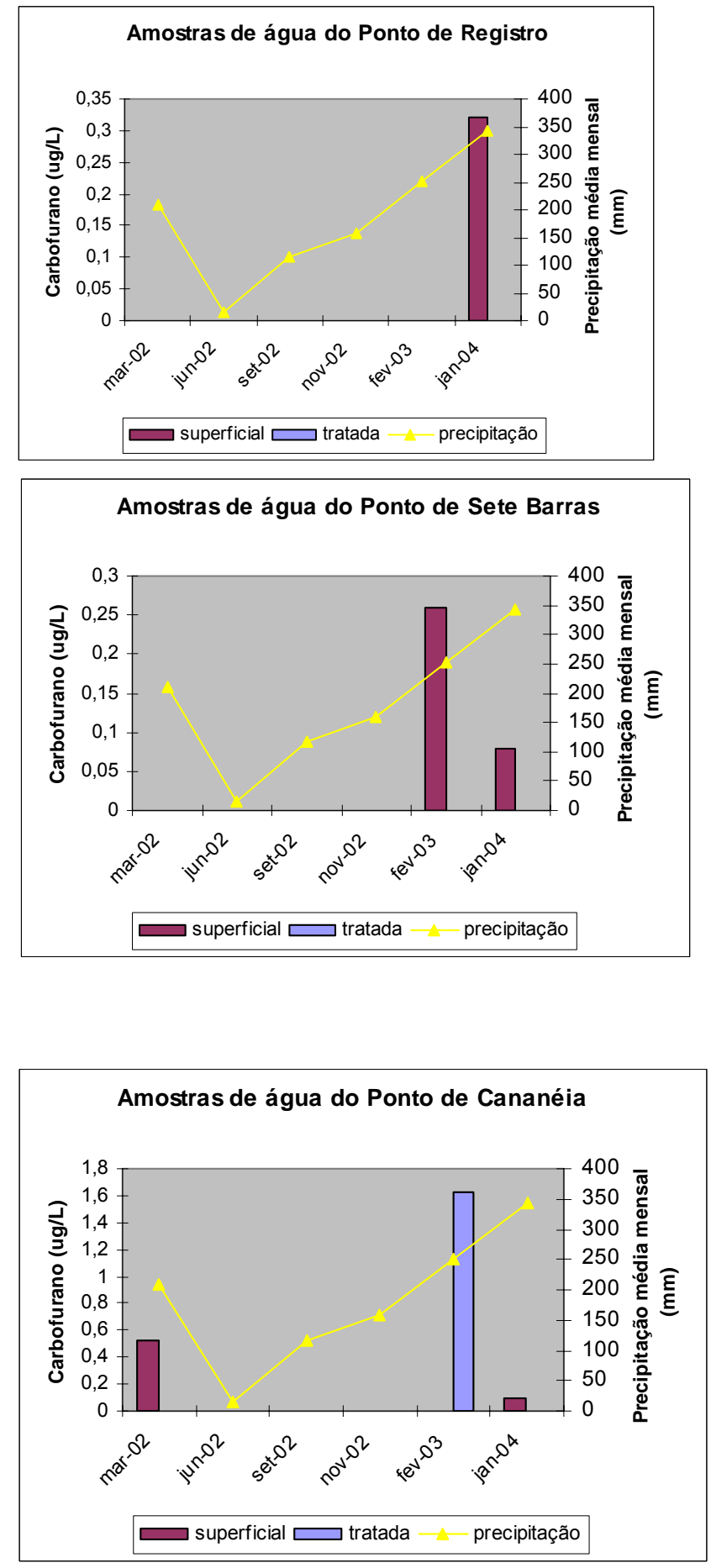

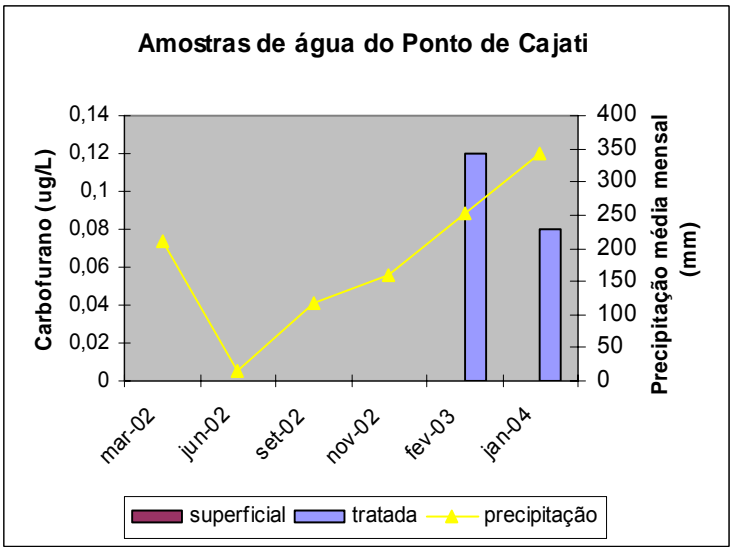

Amostras de água do Ponto de Barra do Turvo

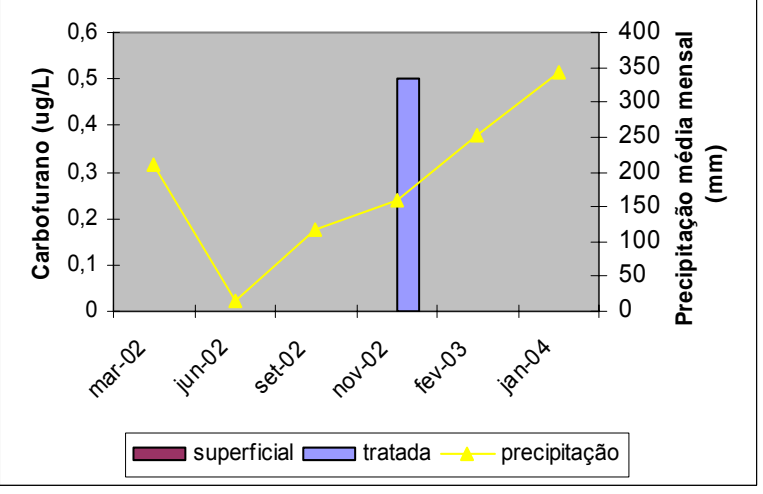

Amostras de água do Ponto de Eldorado

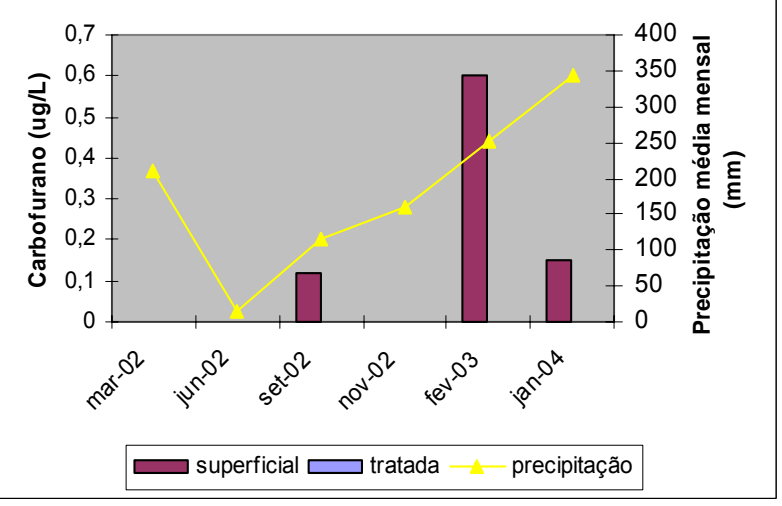

FIGURA 40 - Densidade da distribuição sazonal dos agrotóxicos analisados para os pontos de captação de Registro, Cajati, Sete Barras, Barra do Turvo, Cananéia e Eldorado, no período de março 2002 a fevereiro de 2003 e em janeiro de 2004, água superficial e água tratada, respectivamente. 

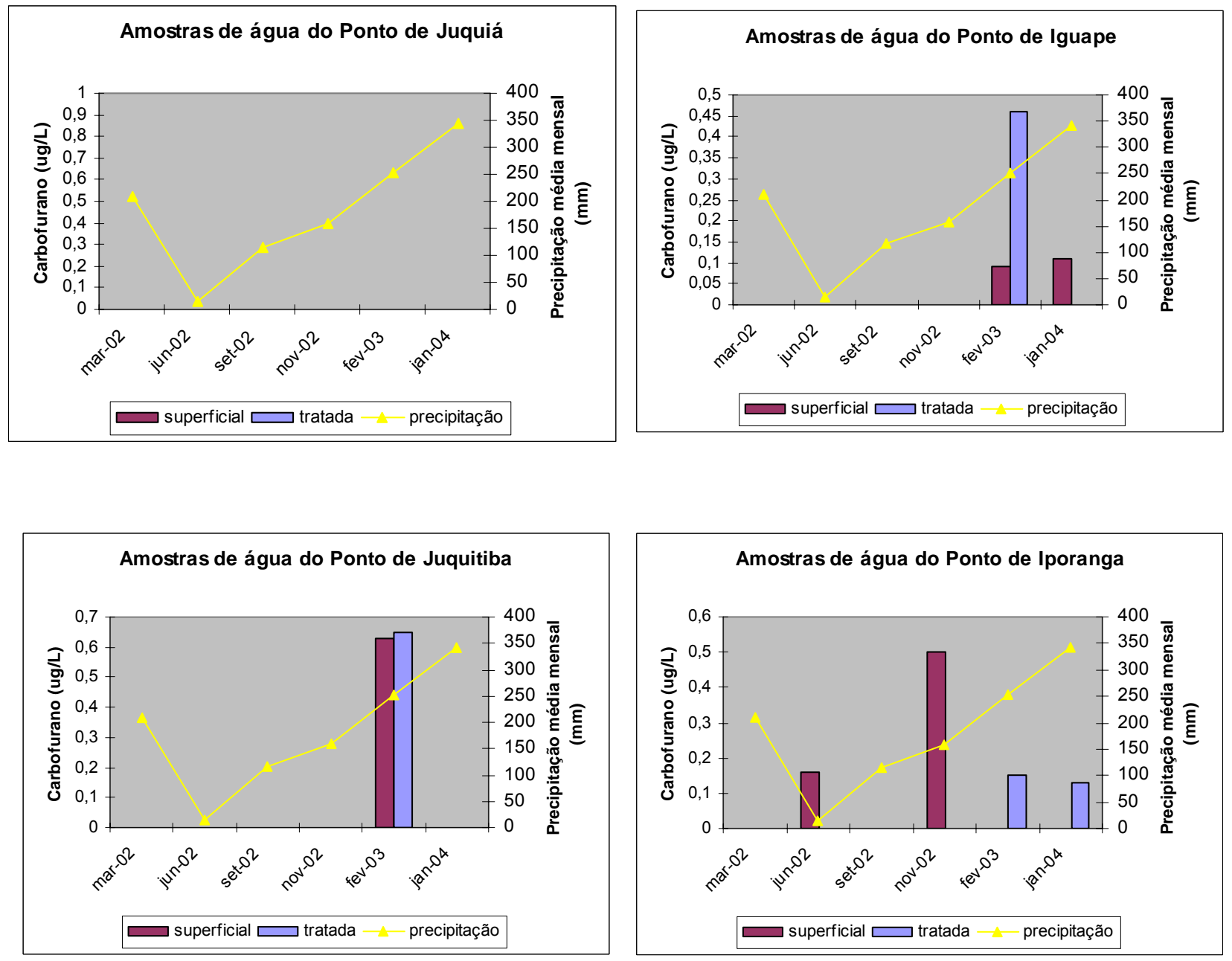

FIGURA 41 - Densidade da distribuição sazonal dos agrotóxicos analisados para os pontos de captação de Juquiá, Iguape, Juquitiba e Iporanga, no período de março 2002 a fevereiro de 2003 e em janeiro de 2004, água superficial e água tratada, respectivamente. 


\subsection{Análise crítica da legislação que estabelece o controle de qualidade das águas destinadas ao consumo humano}

(Portaria nํㅜㅇ/MS/90 - revisada como Portaria nำ1469/MS/00 e revogada como Portaria nํ518/MS/04)

Um dos objetivos específicos do trabalho foi realizar um estudo crítico da legislação que estabelece o controle da qualidade da água destinada ao consumo humano descrita na Portaria nํ36/MS/90 de modo a estabelecer novas necessidades de avaliação, como, a necessidade de introduzir uma avaliação integrada do sistema de bacias contribuintes, principalmente quanto área de captação, juntamente com a necessidade da introdução de novos parâmetros de potabilidade ainda não contemplados nos padrões de potabilidade nacional como por exemplo, novos agrotóxicos amplamente utilizados em todo território Nacional (Lebre, 2000; Pires et al, 2001; Katsuóka, 2001;Pires et al,2002; Pires, 2004).

Durante o segundo semestre de 2000 o Ministério de Estado da Saúde lançou a proposta de revisão dessa e em 29/12/2000 é assinada a Portaria no1469 pelo Sr. Ministro de Estado da Saúde José Serra, sendo publicada em 02/01/2001 e republicada em 10/01/2001. Essa estabelece os procedimentos e responsabilidades relativas ao controle e vigilância da qualidade da água para o consumo humano e seu padrão de qualidade. Recentemente, em substituição a esta foi aprovada a Portaria no 518 , em 25/03/2004.

Este trabalho está inserido dentro de um projeto maior, de parceria IPEN - SABESP - Faculdade de Saúde Pública da Universidade de São Paulo e CETESB. Em reunião realizada em 09/02/2001, foi de consenso do grupo que os objetivos do projeto continuassem a ser os mesmos, só que se passou a se fazer uma análise crítica da Portaria nำ1469, em vigor até 24/04/2004, estudando os itens como: sazonalidade, legislação para pesticidas, uso e preservação de mananciais e outros. Visando sempre a necessidade de se obter uma legislação flexível, que possa ser viável a todas as estações de tratamento e que garanta a saúde do consumidor. 
Após uma série de reuniões técnicas foi observado que era de primordial importância conhecer qual a opinião e sentimento do setor técnico da área de saneamento quanto às alterações ocorridas na legislação e quais os pontos críticos.

Foram consultados os responsáveis pelos laboratórios de controle sanitário e pela produção de água. Esse levantamento foi realizado por meio de reuniões nas várias unidades de saneamento. Os resultados relacionados na TAB.32 foram discutidos e apresentados pelos gerentes das Unidades de Negócios da SABESP, em reunião técnica, realizada no dia 15/03/2001.

TABELA 32 - Alterações da Portaria de potabilidade vigente. Comentários sobre os pontos mais significativos realizados pelos técnicos em saneamento.

\begin{tabular}{|c|c|c|}
\hline $\begin{array}{c}\text { Localização } \\
\text { na Portaria } \\
\text { nำ18/MS/04 }\end{array}$ & Alterações & Comentários \\
\hline $\begin{array}{l}\text { Portaria } \\
\text { Art. } 2^{\circ}\end{array}$ & $\begin{array}{l}\text { A Portaria n-1469/MS/00 foi criada } \\
\text { em substituição à Portaria } \\
\mathrm{n}^{\circ} \mathrm{36/MS/90} \text { e deveria ser cumprida } \\
\text { em quase sua totalidade até } \\
12 / 2002 \text {. }\end{array}$ & $\begin{array}{l}\text { Até junho de } 2003 \text { a Portaria } \\
\text { n-1469/MS/00 não era cumprida em } \\
\text { sua totalidade pela Empresas } \\
\text { Estatais de Saneamento Básico do } \\
\text { país. Como conseqüência, no dia } 25 \\
\text { de março de } 2004 \text { entrou em vigor a } \\
\text { Portaria n518/04 que alterou o } \\
\text { prazo para o seu cumprimento por } \\
\text { mais } 12 \text { meses. }\end{array}$ \\
\hline
\end{tabular}

\begin{tabular}{cl}
\hline Anexo & Mudança do termo: coliformes fecais O principal indicador bacteriológico \\
Capítulo II & para coliformes termotolerantes, \\
Art.4 item & sendo o principal indicador \\
VII & bacteriológico. \\
\hline
\end{tabular}


TABELA 32 - Alterações da Portaria de potabilidade vigente. Comentários sobre os pontos mais significativos realizados pelos técnicos em saneamento (continuação).

\begin{tabular}{|c|c|c|}
\hline $\begin{array}{c}\text { Localização } \\
\text { na Portaria } \\
\text { n-518/MS/04 }\end{array}$ & Alterações & Comentários \\
\hline Art. $2^{\circ} \S 1^{\circ}$ & $\begin{array}{l}\text { Obrigação do monitoramento das } \\
\text { cianobactérias e cianotoxinas que } \\
\text { deveria ser cumprido até } 12 / 2003 \text {. } \\
\text { Prorrogado até } 25 / 03 / 05 \text { pela } \\
\text { Portaria atual. }\end{array}$ & $\begin{array}{l}\text { Este monitoramento é pertinente } \\
\text { para regiões intensamente } \\
\text { urbanizadas como, p. ex., a cidade } \\
\text { de São Paulo e Grande Metrópole } \\
\text { (RMSP). Mas, regiões menos } \\
\text { urbanizadas como o Interior do } \\
\text { Estado não têm problemas } \\
\text { evidentes com as cianobactérias. } \\
\text { Surgindo aqui um impasse para } \\
\text { essas regiões, ter que investir em } \\
\text { infra-estrutura para a metodologia } \\
\text { de determinação de cianobactérias, } \\
\text { comprovar que não existe o } \\
\text { problema e se realizar os ensaios } \\
\text { com maior espaçamento de tempo, } \\
\text { ou seja, investir para praticamente } \\
\text { não fazer. É uma norma difícil de ser } \\
\text { cumprida. }\end{array}$ \\
\hline
\end{tabular}

\begin{tabular}{|c|c|}
\hline Anexo & A inclusão do controle dos Os \\
\hline $\begin{array}{l}\text { Capítulo III } \\
\text { Seção III }\end{array}$ & $\begin{array}{l}\text { mananciais na Portaria delega a internacionais ficaram descobertos } \\
\text { responsabilidade aos órgãos pela portaria vigente. }\end{array}$ \\
\hline $\begin{array}{l}\text { Art.7 } \S 4 \\
\text { Anexo }\end{array}$ & $\begin{array}{l}\text { governamentais, como se observa } \\
\text { na seção III que, delega ao } \\
\text { município, através das Secretarias }\end{array}$ \\
\hline $\begin{array}{l}\text { Capítulo III } \\
\text { Seção IV } \\
\text { art.9 item V }\end{array}$ & $\begin{array}{l}\text { Municipais de Saúde, fiscalizar e } \\
\text { controlar a ocupação dos } \\
\text { mananciais. Estendendo as } \\
\text { responsabilidades no gerenciamento } \\
\text { das bacias as empresas de } \\
\text { abastecimento. }\end{array}$ \\
\hline
\end{tabular}


TABELA 32 - Alterações da Portaria de potabilidade vigente. Comentários sobre os pontos mais significativos realizados pelos técnicos em saneamento (continuação).

\title{
Localização \\ na Portaria \\ n-518/MS/04
}

\section{Alterações Comentários}

\begin{abstract}
Anexo Este campo exige do fornecedor a Este item na norma é positivo e
Capítulo III garantia da qualidade dos necessário, inferindo no aumento de

Seção IV produtos químicos no tratamento custos do tratamento de água.

Art. $9^{\circ}$ item II da água e de materiais Este item também exige critérios mais

$-b, V, V I$ e empregados na produção e rígidos no controle de qualidade dos

VII distribuição que tenham contato produtos.

com a água. $\quad U m$ fator complicador observado foi

Neste artigo, nos seus itens $\mathrm{VI}$ e como disponibilizar vinte e cinco mil VII solicita à empresa responsável análises por mês de forma acessível à pelo abastecimento deverá compreensão da população. O INDEC fornecer a todos os consumidores - Instituto de Defesa ao Consumidor informações sobre a qualidade da certificou o controle de qualidade, água distribuída, nos termos do mas exigiu a disponibilidade dos Código de Defesa do Consumidor. dados de forma compreensível a população.
\end{abstract}

Anexo A Tabela 1 (Portaria) indica os Observou-se que existe ainda um Capítulo IV parâmetros microbiológicos de ponto crítico, pois a portaria admite Art.11 ${ }^{\circ}$ potabilidade da água para como boa a água no sistema de consumo humano. distribuição que apresenta ausência de coliformes totais em $100 \mathrm{ml}$ em 95\% das amostras examinadas no mês, mas não menciona 0 valor máximo permissível para os $5 \%$ que apresentam coliformes totais. Esse item deveria ser revisto.

Os $\S 1, \S 2$ e $\S 7$ são de bom senso e o $§ 8$ traz uma nova interpretação e muda o conceito de análise de coliformes totais para águas de abastecimento sem distribuição canalizada. 
TABELA 32 - Alterações da Portaria de potabilidade vigente. Comentários sobre os pontos mais significativos realizados pelos técnicos em saneamento (continuação).

Localização

na Portaria

nำ518/MS/04

Alterações Comentários

Anexo $\mathrm{O}$ art. 12 e seus respectivos Questionou-se o fato de existir uma

Capítulo IV parágrafos abordam sobre o padrão preocupação de ordem operacional

Art.12 ${ }^{\circ}$ de turbidez para água pós-filtração ou de saúde pública. Porém ou pré-desinfecção. $\quad$ verificou-se que não é de ordem operacional e sim de saúde pública, pois a filtração auxilia no controle e remoção microbiológica.

Outro fator questionado é o fato de a coleta de amostra para filtração rápida ser feito a cada quatro horas e na saída do tratamento a cada duas horas, conforme a tabela 7 .

\begin{tabular}{|c|c|c|}
\hline $\begin{array}{l}\text { Anexo } \\
\text { Capítulo IV } \\
\text { Art. } 13^{\circ}\end{array}$ & $\begin{array}{l}\text { Referente à cloração recomenda-se } \\
\text { que esta seja feita em } \mathrm{pH} \text { inferior a } \\
8,0 \text {. }\end{array}$ & $\begin{array}{l}\text { Este } \mathrm{pH} \text { é muito elevado, pois na } \\
\text { curva de desinfecção quanto menor } \\
\text { o pH maior a eficiência da cloração } \\
\text { por tempo de contato. }\end{array}$ \\
\hline $\begin{array}{c}\text { Anexo } \\
\text { Capítulo IV } \\
\text { Art. } 14^{\circ}\end{array}$ & $\begin{array}{l}\text { Estabelece na Tabela } 3 \text { (Portaria) } \\
\text { que o valor máximo permitido de } \\
\text { fluoreto para água potável foi } \\
\text { alterado para } 1,5 \mathrm{mg} / \mathrm{L} \text {. } \\
\S 1 \text { faz recomendações para } \\
\text { análise de cianotoxinas e no } \S 2 \\
\text { recomenda-se a determinação de } \\
\text { organofosforados e carbamatos. }\end{array}$ & $\begin{array}{l}\text { Existe a necessidade da área de } \\
\text { saneamento e da vigilância sanitária } \\
\text { da região metropolitana em } \\
\text { conhecer mais sobre estes } \\
\text { parâmetros inclusos neste artigo. } \\
\text { Outra questão delicada é qual será } \\
\text { impacto e como se dará a } \\
\text { implantação deste artigo em todo o } \\
\text { Brasil. }\end{array}$ \\
\hline $\begin{array}{l}\text { Anexo } \\
\text { Capítulo IV } \\
\text { Art. } 15^{\circ}\end{array}$ & $\begin{array}{l}\text { Aborda a questão sobre o padrão de } \\
\text { radioatividade. }\end{array}$ & $\begin{array}{l}\text { Este artigo não está claro uma vez } \\
\text { que já estava anistiado. Cabe } \\
\text { salientar que o IPEN realiza estas } \\
\text { análises, com reavaliações } \\
\text { periódicas. }\end{array}$ \\
\hline
\end{tabular}


TABELA 32 - Alterações da Portaria de potabilidade vigente. Comentários sobre os pontos mais significativos realizados pelos técnicos em saneamento (continuação).

Localização

na Portaria

nำ518/MS/04

Alterações Comentários

Anexo Relata que a água potável deve Cabe salientar que estações de

Capítulo IV estar em conformidade com o tratamento não são o lugar

Art.16 ${ }^{\circ}$ padrão de aceitação de consumo adequado para se fazer testes de expresso na tabela 5 (Portaria). No gosto e odor, devido ao forte cheiro $\S 1$ recomenda-se que, no sistema e de cloro. $\mathrm{E}$ nas redes de de distribuição, o pH da água seja distribuição estes já possuem um mantido na faixa de 6,0 a 9,5 . E no indicador os consumidores, que seu $\S 3$ recomenda-se a realização ligam informando quando detectam de testes para detecção de gosto e gosto e odor fora do normal.

odor em amostras coletadas na

saída do tratamento e na rede de

distribuição.

$\begin{array}{ll}\text { Anexo } & \text { A Portaria recomenda as normas Este item vem ao encontro das } \\ \text { Capítulo IV } & \text { nacionais ou as metodologias exigências atuais de se inserir o } \\ \text { Art.170 } & \text { citadas na edição mais recente do sistema de qualidade nas } \\ & \text { Standard Methodods for the Empresas, garantindo assim a } \\ & \text { Examination of Water and qualidade do produto final. } \\ & \text { Wastewater ou as normas Mas a implantação de um sistema } \\ & \text { publicadas pela ISO (International de controle da qualidade } \\ & \text { Standartization Organization). Os modernizado e com condições } \\ & \text { laboratórios das empresas mínimas de análise mais } \\ & \text { responsáveis pelo abastecimento sofisticadas, para alguns parâmetros } \\ & \text { público deverão ser credenciados ou novos, têm como conseqüência o } \\ & \text { participar de programas de garantia aumento de custos. } \\ & \text { da qualidade segundo o } \S 3 \text { deste } \\ & \text { artigo }\end{array}$


TABELA 32 - Alterações da Portaria de potabilidade vigente. Comentários sobre os pontos mais significativos realizados pelos técnicos em saneamento (continuação).

\begin{tabular}{|c|c|c|}
\hline $\begin{array}{c}\text { Localização } \\
\text { na Portaria } \\
\text { n518/MS/04 }\end{array}$ & Alterações & Comentários \\
\hline $\begin{array}{c}\text { Anexo } \\
\text { Capítulo V } \\
\text { Art. } 18^{\circ}\end{array}$ & $\begin{array}{l}\text { Descreve os planos de amostragem; } \\
\text { Tabelas 6, 7, } 8 \text { e } 9 \text { (Portaria). } \\
\S 1 \text { A amostragem deve obedecer } \\
\text { aos seguintes requisitos: distribuição } \\
\text { uniforme das coletas ao longo do } \\
\text { período; e representatividade dos } \\
\text { pontos de coleta no sistema de } \\
\text { distribuição. } \\
\text { Segundo essa portaria as análises } \\
\text { dos parâmetros como: cor, turbidez, } \\
\text { teor de flúor, etc., com amostragem } \\
\text { a cada duas horas para captação de } \\
\text { água superficial, deixarão de ser um } \\
\text { controle operacional e passarão a } \\
\text { fazer parte do controle da qualidade. }\end{array}$ & $\begin{array}{l}\text { Quanto a este parágrafo embora } \\
\text { seja muito importante do ponto de } \\
\text { vista de saúde e controle é ruim do } \\
\text { ponto de vista estatístico. Pois para } \\
\text { pequenos municípios o número de } \\
\text { amostras diminuiu em relação à } \\
\text { Portaria no-36/MS/90 e o inverso } \\
\text { ocorreu para os grandes municípios. } \\
\text { Na FIG.42 é mostrado um exemplo } \\
\text { de comparação para análise de } \\
\text { coliformes totais. }\end{array}$ \\
\hline $\begin{array}{c}\text { Anexo } \\
\text { Capítulo VI } \\
\text { Art. } 21^{\circ}\end{array}$ & $\begin{array}{l}\text { Define e estabelece } \\
\text { responsabilidade para a operação } \\
\text { do sistema de abastecimento, ou } \\
\text { seja, deve-se ter um técnico, } \\
\text { profissionalmente habilitado, para se } \\
\text { responsabilizar pelo sistema. }\end{array}$ & \\
\hline
\end{tabular}

Cintra Filho (2001) discute o aumento no número de parâmetros e de análise para o setor de produção de água para o abastecimento, e cita como exemplo a análise de coliformes totais para cidades com mais de 150.000 habitantes, FIG.42. 


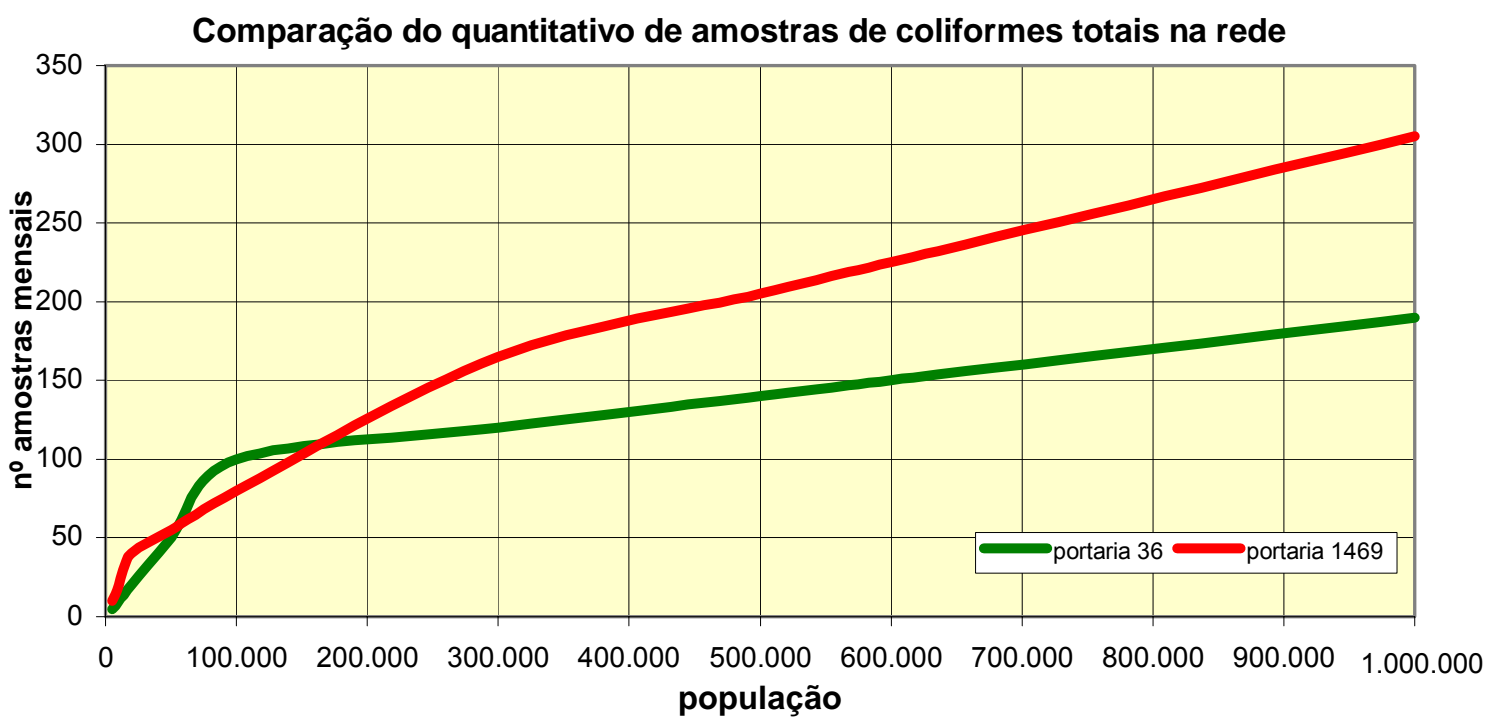

FIGURA 42 - Comparação quantitativa de amostras em populações entre 1 e 1.000.000 de habitantes (Cintra Filho, O. A.,2001).

\subsubsection{Comparação dos atuais parâmetros de potabilidade nacional com outras legislações}

Para esta comparação vale salientar que na legislação nacional os mandamentos jurídicos por ordem de importância (hierarquia) são:

- Constituição Federal - lei maior e que deve regrar e ser obedecida por todas as outras leis.

- Decreto - editado somente pelo chefe do Poder Executivo para regulamentar as leis.

- Portarias - ato regulamentar para dirigir-se a subordinados sobre decisões internas utilizadas por autoridades.

- Resoluções - ato regulamentar utilizado por órgãos colegiados para exprimir deliberações da sua competência.

A Portaria no $518 / \mathrm{MS} / 04$ estabelece os procedimentos e responsabilidades relativos ao controle e vigilância da qualidade da água para consumo humano e seu padrão de potabilidade. Na TAB.A, do APÊNDICE A, é 
apresentada uma comparação dos parâmetros de potabilidade e valores máximos permissíveis (VMP) com demais normas e legislações: Portaria no 36/MS/90, Decreto Estadual-SP no 12.486/78, guia para a qualidade de água potável da Organização Mundial da Saúde - OMS/95, Resolução CONAMA no 20/86 e os padrões de potabilidade de água aconselháveis a saúde, recomendados pela Agência de Proteção ao Meio Ambiente do Estados Unidos - EPA/00.

A Resolução CONAMA no 20/86, dispõe sobre a classificação dos corpos d’água doce, salobras e salinas; padrões de qualidade de emissão e balneabilidade. As classes de água doce especial, 1, 2, e 3 são destinadas ao abastecimento doméstico com ou sem tratamento convencional. Visando fazer um estudo comparativo dos parâmetros destas classes com os parâmetros de potabilidade foram avaliados os pontos mais relevantes dessas legislações descritos nas TAB.33 e 34 .

Analisando-se os pontos críticos levantados na TAB.32 verifica-se que o custo para se cumprir a Portaria no 1460/MS/00, atual Portaria no 518/MS/04, é maior que o custo para cobrir a antiga Portaria no 36/MS/90 e alguns parâmetros inclusos com relação à determinação de metais e orgânicos estão fora da realidade brasileira. Enfatizando-se que as recomendações dessa portaria podem se tornar imposições na próxima revisão e ainda nas resoluções Estatais podem dar obrigatoriedade às recomendações da portaria.

Analisando-se as informações contidas nas TAB.33 e 34 , as quais descrevem as diferenças e pontos relevantes existentes entre os parâmetros químicos e legislações de potabilidade, verifica-se que houve um sensível aumento de parâmetros controlados e diminuição nos valores máximos permissíveis (VMP) dos parâmetros existentes. Observou-se que a atual legislação Brasileira de potabilidade segue o guia de potabilidade da Organização Mundial da Saúde, indicando que esta foi redigida utilizando a mesma como uma das fontes de referência, sendo mais restritiva que a americana. 
TABELA 33 - Pontos relevantes estabelecidos entre os parâmetros químicos de potabilidade $e$ as legislações nacionais referentes à qualidade da água

\section{Legislação}

\section{Pontos relevantes}

Foram alterados alguns valores máximos permissíveis, foram excluídos dos parâmetros de potabilidade a prata, o toxafeno e o fenol e incluídos 28 novos parâmetros no total. Sendo destes, 5 Portaria nํㅜ $36 / \mathrm{MS} / 90$ inorgânicos, 5 orgânicos, 12 agrotóxicos, 5 substâncias que afetam a qualidade organoléptica e as microcistinas produzidas pelas cianobactérias.

Dos 12 agrotóxicos inclusos: 10 são herbicidas, um é inseticida e o outro é um inseticida e acaricida.

Existem 59 parâmetros que constam na Portaria nำ 518/MS/04 e não constam no DE-SP no $12.486 / \mathrm{SP} / 78$ e mais 4 que constam no Decreto DE-SP no $12.486 / S P / 78$ e não constam na Portaria no 518/MS/04. Estadual-SP

no $\quad$ Dos 18 parâmetros comuns as duas legislações 11 possuem 12.486/SP/78 valores máximos permissíveis diferentes, sendo que destes 7 são mais restritivos na Portaria $\mathrm{n}$ - 518/MS/04 que no DE-SP no $12.486 / \mathrm{SP} / 78$

Existem 36 parâmetros que constam na Portaria nำ 518/MS/04 e não constam no CONAMA 20/86 e mais 32 que constam no CONAMA CONAMA 20/86 e não constam na Portaria nำ 518/MS/04.

$\mathrm{n}-20 / 86$

Dos 43 parâmetros comuns as duas legislações 29 possuem valores máximos permissíveis diferentes, sendo que destes 23 são mais restritivos no CONAMA $\mathrm{n}^{-} 20 / 86$ que na Portaria $\mathrm{n}^{\circ}$ 518/MS/04. 
TABELA 34 - Pontos relevantes estabelecidos entre os parâmetros químicos da atual Portaria no 510/MS/04 e as legislações internacionais referentes à qualidade da água

\begin{tabular}{|c|c|}
\hline Legislação & Pontos relevantes \\
\hline $\begin{array}{c}\text { Guia de } \\
\text { potabilidade } \\
\text { da OMS/95 }\end{array}$ & $\begin{array}{l}\text { Os parâmetros da Portaria n } 518 / M S / 04 \text { são iguais ou próximos } \\
\text { aos recomendados pela OMS/95. }\end{array}$ \\
\hline $\begin{array}{c}\text { Padrões de } \\
\text { potabilidade } \\
\text { EPA/03 }\end{array}$ & $\begin{array}{l}\text { Existem } 20 \text { parâmetros que constam na Portaria no 518/MS/04 e } \\
\text { não constam no EPA/03 e mais } 24 \text { que constam no EPA/03 e não } \\
\text { constam na Portaria no } 518 / M S / 04 \text {. } \\
\text { Dos } 54 \text { parâmetros comuns as duas legislações } 40 \text { possuem } \\
\text { valores máximos permissíveis diferentes, sendo que destes } 18 \text { são } \\
\text { mais restritivos no EPA/00 que na Portaria nำ } 518 / M S / 04 \text {. }\end{array}$ \\
\hline
\end{tabular}

Os estudos comparativos também mostraram que, aproximadamente, $43 \%$ dos parâmetros inclusos na Portaria vigente são agrotóxicos indicando a importância deste no monitoramento e avaliação ambiental. Os doze princípios ativos de agrotóxicos inclusos estão apresentados na TAB.E do APÊNDICE E contendo informações relevantes são eles: alaclor, atrazina, bentazone, endossulfan, glifosato, metolacloro, molinato, pendimetalina, permetrina, propanil, simazina e trifluralina. Destes somente quatro princípios ativos estão entre os dez mais consumidos no Brasil: o glifosato, a atrazina, o endosulfan e a trifluralina (TAB.2, pág.18). 


\subsubsection{Situação atual das Empresas Estatais de Saneamento Básico no cumprimento da Portaria atual de potabilidade}

A seguir são apresentadas as informações fornecidas pelos representantes técnicos das Empresas Estatais de Saneamento Básico a respeito da situação das empresas no cumprimento da Portaria. Esses dados foram apresentados pela Associação das Empresas de Saneamento Básico Estaduais AESBE (junho de 2003, Belo Horizonte), e discutido no segundo Workshop: Aspectos Legais da Qualidade da Água. Impactos de uso múltiplos e suas implicações na Portaria nำ 1469/MS/00, realizado no IPEN/CNEN-SP, em 17/06/2003. Os resultados apresentados nas TAB.35 e 36 são referentes às informações obtidas de 22 empresas estatais consultadas. Na TAB.37 são apresentados os números de laboratórios capacitados em realizar os parâmetros com estrutura laboratorial própria.

Estas Tabelas mostram que 90\% das Empresas Estatais de Saneamento Básico do país ainda não estão capacitadas e não possuem estrutura física para atender a legislação de potabilidade (dados de 2003), devido ao grande aumento de parâmetros e custo elevado para a sua realização. Principalmente, para atender as análises dos compostos orgânicos, tanto pela dificuldade de se obter recursos humanos especializados como por exigir técnicas complexas e onerosas.

A Portaria de potabilidade atual aborda fatores e parâmetros de fundamental importância para a saúde pública e suas exigências se igualam aos países de "primeiro mundo", mas o nosso País e o seu sistema de saúde, não.

Outro fator que dificulta a implantação desta Portaria é a extensão territorial do país e suas diferenças nos diversos cenários como: climáticas, geológicas, disponibilidade hídrica, demanda dos recursos hídricos bem como a desigualdade na oferta de água encanada e, conseqüentemente, as diferenças no uso e ocupação do solo. Portanto, alguns parâmetros poderiam ser remetidos a políticas públicas estatais as quais contariam com a presença de representantes dos comitês de bacias para a suas elaboração. 
TABELA 35 - Empresas Estatais de Saneamento Básico com estrutura laboratorial própria.

\begin{tabular}{|c|c|c|c|c|c|}
\hline EMPRESAS & $\begin{array}{l}\text { № } \\
\text { lab. }\end{array}$ & $\begin{array}{c}\text { Compostos } \\
\text { orgânicos }\end{array}$ & Metais & $\begin{array}{l}\text { Bacteriologia } \\
\text { coliformes } \\
\text { totais e } \\
\text { heterotróficas }\end{array}$ & Cianobactérias \\
\hline SENEPAR/PR & 4 & incompleta & completa & completa & completa \\
\hline EMBRASA/BA & 14 & incompleta & completa & completa & completa \\
\hline CESAN/ES & 2 & não tem & não tem & completa & completa \\
\hline COMPESA/PE & 13 & incompleta & completa & completa & completa \\
\hline SANEAGO/GO & 15 & incompleta & completa & completa & não tem \\
\hline CEDAE/RJ & 12 & incompleta & completa & completa & completa \\
\hline SABESP/SP & 15 & completa & completa & completa & completa \\
\hline CAESB/DF & 1 & não tem & completa & completa & completa \\
\hline CAEMA/MA & 9 & não tem & não tem & completa & não tem \\
\hline SANATINS/TO & 4 & não tem & não tem & completa & completa \\
\hline CORSAN/RS & 170 & incompleta & completa & completa & completa \\
\hline AGESPISA/PI & 3 & não tem & não tem & incompleta & não tem \\
\hline SANESUL/MS & 8 & incompleta & não tem & incompleta & incompleta \\
\hline CASAN/SC & 10 & não tem & incompleta & completa & incompleta \\
\hline CAGEPA/PB & 12 & incompleta & incompleta & incompleta & incompleta \\
\hline CAESA/AP & 1 & não tem & incompleta & incompleta & não tem \\
\hline CAERN/RN & 7 & não tem & não tem & incompleta & não tem \\
\hline COSANPA/PA & 1 & não tem & não tem & incompleta & não tem \\
\hline CAGECE/CE & 7 & incompleta & incompleta & completa & completa \\
\hline COPASA/MG & 6 & incompleta & completa & completa & completa \\
\hline CAERD/RD & 1 & não tem & não tem & incompleta & não tem \\
\hline CASAL/AL & 4 & não tem & incompleta & incompleta & não tem \\
\hline
\end{tabular}

Fonte: Cintra Filho: Workshop - Realizado no IPEN/CNEN-SP, em 17/06/2003. 
TABELA 36 - Análises e a freqüência das coletas.

\begin{tabular}{|c|c|c|c|c|c|}
\hline EMPRESAS & $\begin{array}{l}\text { № } \\
\text { lab. }\end{array}$ & $\begin{array}{c}\text { Compostos } \\
\text { orgânicos }\end{array}$ & Metais & $\begin{array}{l}\text { Bacteriologia } \\
\text { final (F) e } \\
\text { rede (R) }\end{array}$ & Cianobactérias \\
\hline SENEPAR/PR & 4 & completo (1) & completo & R e F $(86 \%)$ & completo \\
\hline EMBRASA/BA & 14 & não faz & parcial (G) & $\operatorname{Re} F(G)$ & completo \\
\hline CESAN/ES & 2 & parcial $1(G)$ & parcial $1(G)$ & $\operatorname{Re} F(G)$ & completo \\
\hline COMPESA/PE & 13 & não faz & parcial (G) & $\operatorname{Re} F(G)$ & completo \\
\hline SANEAGO/GO & 15 & não faz & completo & $\operatorname{Re} F(G)$ & não faz \\
\hline CEDAE/RJ & 12 & completa (1) & completo & $\operatorname{Re} F(G)$ & completo \\
\hline SABESP/SP & 15 & parcial & completo & $\operatorname{Re} F(G)$ & parcial \\
\hline CAESB/DF & 1 & não faz & parcial & completa & completo \\
\hline CAEMA/MA & 9 & parcial $1(G)$ & parcial $1(G)$ & parcial $1(G)$ & parcial \\
\hline SANATINS/TO & 4 & parcial (G) & parcial (G) & parcial (G) & parcial (G) \\
\hline CORSAN/RS & 170 & parcial (G) & parcial (G) & completa & completo (1) \\
\hline AGESPISA/PI & 3 & não faz & não faz & parcial (G) & não faz \\
\hline SANESUL/MS & 8 & parcial & não faz & parcial (G) & parcial \\
\hline CASAN/SC & 10 & não faz & parcial (G) & parcial (G) & parcial (G) \\
\hline CAGEPA/PB & 12 & parcial (G) & parcial (G) & parcial (G) & parcial (G) \\
\hline CAESA/AP & 1 & parcial (G) & parcial (G) & parcial (G) & não faz \\
\hline CAERN/RN & 7 & parcial (G) & parcial (G) & parcial (G) & parcial (G) \\
\hline COSANPA/PA & 1 & não faz & não faz & parcial (G) & não faz \\
\hline CAGECE/CE & 7 & não faz & não faz & parcial (G) & completo \\
\hline COPASA/MG & 6 & parcial (G) & completo & parcial (G) & completo \\
\hline CAERD/RD & 1 & não faz & não faz & parcial (G) & não faz \\
\hline CASAL/AL & 4 & não faz & parcial (G) & parcial (G) & não faz \\
\hline
\end{tabular}

OBS: (1) com serviço terceirizado; $(\mathrm{G})$ apenas nas grandes cidades.

Fonte: Cintra Filho: Workshop - Realizado no IPEN/CNEN-SP, em 17/06/2003. 
TABELA 37 - Número de Empresas Estatais de Saneamento Básico com estrutura laboratorial própria que executam os parâmetros da legislação de potabilidade vigente.

\begin{tabular}{ccccc}
\hline Situação & $\begin{array}{c}\text { Compostos } \\
\text { orgânicos }\end{array}$ & Metais & $\begin{array}{c}\text { Bacteriológico } \\
\text { coliformes totais Cianobactérias } \\
\text { e heterotróficas }\end{array}$ & \\
\hline Completa & 2 & 9 & 14 & 5 \\
\hline Incompleta & 9 & 5 & 8 & 8 \\
\hline Não possuem & 11 & 8 & - & 22 \\
\hline Total & 22 & 22 & 22 & \\
\hline
\end{tabular}

Fonte: Cintra Filho: Workshop - Realizado no IPEN/CNEN-SP, em 17/06/2003. 


\section{CONCLUSÕES}

O desenvolvimento do trabalho permitiu concluir que o monitoramento da qualidade da água deve ser direcionado a problemas específicos, principalmente levando-se em conta problemas regionais e uso e ocupação do solo. Os estudos mostraram a dependência da composição da água com as características do ecossistema adjacente.

A agricultura é um dos principais fatores impactantes, mesmo em áreas consideradas ambientalmente preservadas. A utilização de métodos analíticos extremamente sensíveis permitiu identificar a presença de agrotóxicos utilizados na região não contemplados na legislação vigente. Dessa forma foi verificado que as substâncias objeto de normas nacionais devem ser cuidadosamente selecionadas. Vários fatores devem ser considerados como as características geológicas da região e o uso e ocupação do solo, sendo de primordial importância o tipo de atividade humana desenvolvida. As características gerais da qualidade da água natural são muito variáveis e derivam dos ambientes por onde circulam, percolam ou são armazenadas.

A bacia hidrográfica do Rio Ribeira de Iguape é um importante ecossistema para o desenvolvimento regional e estadual, no tocante a disponibilidade de recursos hídricos, contemplando o principal bioma do estado a Mata Atlântica. Atualmente este sistema tem sido estudado sob vários aspectos, principalmente social e ambiental (Programa SOS - Mata Atlântica).

A seleção dessa área piloto levou em conta aspectos socioeconômicos, bióticos e abióticos, políticos, técnicos e funcionais, abordando o núcleo temático de recursos hídricos-captação, tratamento e distribuição de água. Foram observadas estações de base, isto é locais com pouca ou nenhuma atividade antrópica (como área de proteção ambiental e estação ecológica - Mata Atlântica/Vale do Ribeira), bem como áreas urbano-rurais como os Municípios de Registro, Cajati e Iguape. 
Por ser considerada uma das maiores áreas com preservação de Mata Atlântica do estado, carente de área industrial e com intensa atividade agrícola o diagnóstico ambiental realizado forneceu uma fotografia atual do impacto agrícola na região. Foram estudadas áreas de captação destinadas ao abastecimento público pertencente à bacia hidrográfica de Ribeira de Iguape. Caracterizou-se e avaliou-se a qualidade da água da região e verificou-se as inter-relações entre os aspectos básicos de metereologia, hidrologia e uso agrícola do solo.

Embora a região do Ribeira de Iguape tenha grande parte de sua área (92\%) preservada por Parques Estaduais, Áreas de Proteção Ambiental (APA) e santuários ecológicos como o da Juréia, esta já apresenta sinais de impactos antrópicos, tais como: a extração "depredatória" do palmito, presença de pastos para bovinos em APAs, monocultura de banana sem respeitar áreas de mata ciliar além da extração mineral de areia, a quais representam grandes problemas na contaminação dos seus recursos hídricos pela possível disponibilidade de metais tóxicos em água.

Quanto ao diagnóstico realizado para verificar a contaminação causada pelo uso de agrotóxicos nos corpos d'água, pode-se concluir que a escolha dos agrotóxicos para estudo do monitoramento deve levar em conta fatores primordiais, entre eles: índice de aplicação na região, pertencerem ao grupo de agrotóxicos contemplados pela OMS e FAO, a persistência destes compostos no meio ambiente (os carbamatos - aldicarbe, carbaril, carbofurano - são inseticidas com persistência no meio ambiente de 1 a 18 meses) e alguns destes, recentemente, inclusos no controle de potabilidade como a atrazina, a simazina (grupo das triazinas que estão entre os herbicidas mais utilizados no mundo) a trifluralina (grupo das nitroanilinas).

Verificou-se que a qualidade da água é influenciada pela sazonalidade. Em períodos de chuva, detectou-se uma concentração maior de agrotóxicos na água superficial provocada pela lixiviação do solo pela chuva. Observou-se que as amostra de água superficial apresentaram uma maior incidência de resíduos de carbofurano, fato previsto e comprovado devido à grande mobilidade em meio aquoso. As amostras positivas apresentaram maior freqüência de observações 
durante os períodos de chuva, principalmente, quando os índices pluviométricos ultrapassam os $300 \mathrm{~mm}$ na média mensal. Um dos principais fatores contribuintes foram as enchentes, que ocorrem com grande freqüência neste período. Embora, as concentrações observadas dos resíduos de agrotóxicos fossem concentrações baixas, os resultados mostram indícios de contaminação e do impacto da agricultura nos corpos d'águas da bacia hidrográfica do Rio Ribeira de Iguape.

A análise preliminar do risco potencial de contaminação por agrotóxicos em águas superficiais e subterrâneas permitiu observar que:

- embora, a maior parte da região esteja em área de proteção ambiental a agricultura pode ser apontada como um dos fatores impactantes da bacia;

- a maioria dos agrotóxicos utilizados na região apresentaram alta mobilidade no meio ambiente e foram classificados como possíveis contaminantes de águas subterrâneas, por meio de suas características físico-químicas.

Outro fator contribuinte para agravar o impacto da agricultura na qualidade da água é o tipo de aqüífero e o de solo. A região possui aqüíferos sedimentares e cristalinos não confinados e, os tipos de solo - dominante da depressão do Baixo Ribeira (Podzólico), das Planícies Fluviais (Glei Hêmico) e Planície Litorânea (Podzol Hidromérfico), (FIG.10) - que são solos de texturas predominantemente arenosa com boa permeabilidade da água (Embrapa, 1999; Hassuda, 2000).

O alto índice pluviométrico é outro fator favorável à contaminação. A região apresentou uma precipitação média anual de $1758 \mathrm{~mm}$, no período de 2000 - 2003 (FIG.23, pág.92), valor este bem superior aos $250 \mathrm{~mm}$ sugeridos pela EPA para caracterizar as áreas com potencial de contaminação de águas subterrâneas. 
Ações de controle de uso e preservação das áreas de captação devem ser observadas. A primeira linha de defesa é proteger a água da contaminação. $\mathrm{O}$ melhor método é proteger a fonte, procedimento preferível ao tratamento da água contaminada de forma a tornar-se apta para consumo humano.

Avaliando-se as características físico-químicas da água superficial e tratada pode-se verificar a eficiência dos processos de tratamento aplicados nas ETA`s da Unidade de Negócio do Vale do Ribeira da SABESP, no item 6.5. Os parâmetros estudados ( $\mathrm{pH}$, cor e turbidez) apresentaram homogeneidade para os valores obtidos na análise da água tratada além de estarem dentro das faixas indicadas pela legislação de potabilidade vigente. A turbidez da água está associada ao material particulado em suspensão, portanto o tratamento e controle deste parâmetro devem auxiliar no controle dos agrotóxicos estudados que apresentaram potencial alto de transporte associado ao sedimento como o propiconazole, paraquate , glifosato, atrazina, trifluralina e simazina.

A avaliação ambiental da bacia torna-se um importante instrumento que poderá contribuir não só para a avaliação da qualidade da água e o entendimento da dinâmica do sistema, mas também para a escolha de medidas de manejo e recuperação deste ecossistema.

A metodologia para a determinação dos carbamatos, triazinas e nitroanilinas por SPE - LC - MS/MS desenvolvida e aplicada, na última etapa do trabalho, mostrou-se eficiente apresentando ótima sensibilidade e seletividade. Os limites de determinação propostos apresentaram boa recuperação para os compostos atrazina, simazina, carbaril, carbofurano, 3-OH-carbofurano. Embora, a recuperação em $10 \mathrm{ngL}^{-1}$ para os composto aldicarbe, aldicarbe sulfona, metomil e trifluralina tenham apresentado valores menores que $70 \%$ apresentou boa seletividade nesta concentração.

O desenvolvimento de um método com esta sensibilidade e seletividade, no âmbito nacional, traz uma contribuição valiosa para programas de avaliação ambiental e toxicológica, além de possibilitar que futuramente a 
legislação de potabilidade venha diminuir os valores máximos permissíveis deste compostos.

A legislação atual de controle de potabilidade é completa por não somente amostragem e parâmetros físico-químicos mas também abordar temas como preservação dos mananciais, e direitos e informações para o consumidor e controle de qualidade dos produtos químicos utilizados no tratamento de água. Porém, esta abrangência e o aumento de parâmetros físico-químicos, principalmente de parâmetros orgânicos, gerou dificuldades técnicas e aumento de custos dificultando o seu cumprimento no prazo legal pela Empresas de Saneamento do país, como se pode verifica nas TAB.35 e 36. Outro fator primordial é a necessidade de uma rede de laboratórios acreditados pelo Inmetro para atender aos padrões recomendados pelas normas brasileiras.

Ao se comparar todos os agrotóxicos listados na Portaria no 518/MS/04 verifica-se que estes são recomendados pela OMS/95 (APÊNDICE A) e seus VMP são iguais ou próximos da mesma. Mas quando comparados com a TAB.2, a qual, lista dos dez agrotóxicos com maior volumes de consumo no Brasil, somente cinco constam na lista são eles: glifosato, atrazina, 2,4 - D, Endossulfan e trifluralina. Este fato mostra a necessidade de um direcionamento melhor entre os diversos órgãos e instituições públicas do país na organização de um banco de dados com as informações geradas por estes. Fatos como estes levam a criação de políticas públicas deficientes e muitas vezes fora da realidade Nacional, pois são baseadas em informações geradas por órgãos internacionais, normalmente, fornecidas por países desenvolvidos e com uma realidade completamente diferente da realidade brasileira.

A implantação de uma legislação única em todo território nacional é dificultada pela dimensão continental do país e as diferentes realidades com relação ao uso e ocupação do solo e dos recursos hídricos em toda a sua extensão.

O monitoramento dos compostos orgânicos, principalmente os agrotóxicos necessitam de análise elaboradas exigindo tecnologia de ponta e mão 
de obra especializada. Dessa forma, um controle mais efetivo deveria ocorres nas áreas onde as atividades com agronegócios sejam mais intensas.

Avaliando os dados apresentados sobre o uso de agrotóxicos nos estados, sobrepondo essas informações com os parâmetros estabelecidos pela atual Portaria no 518/MS/04 (APÊNDICE A) podemos observar que os principais parâmetros abordados, os agrotóxicos, no total de 12 parâmetros incluídos, estão entre os produtos amplamente utilizados nas principais culturas do País. Dessa forma, podemos observar que a Portaria vem ao encontro das necessidades do controle de qualidade da água de abastecimento de estados com grande desenvolvimento agrícola, como os estados das Regiões Sul, Sudeste e Centro Oeste.

Um dos grandes desafios na área de políticas públicas é harmonizar o desenvolvimento econômico/industrial com a preservação do meio ambiente, de forma que a exploração destes recursos não acarrete maiores danos aos ambientes e ao homem. Dessa forma, os recursos hídricos, principalmente os recursos hídricos destinados ao abastecimento público, devem ser integrados a um planejamento regional dentro do contexto holístico unindo o conhecimento científico e a ação do poder público para sua utilização e manutenção. 
APÊNDICE A - Tabela de comparação dos parâmetros de qualidade de água de diferentes legislações.

TABELA A - Parâmetros de qualidade de água de legislações Federais, do Estado de São Paulo e Internacionais.

\begin{tabular}{|c|c|c|c|c|c|c|c|c|c|c|c|c|}
\hline \multirow{3}{*}{ PARÂMETROS } & \multirow{3}{*}{ UNIDADES } & \multirow{3}{*}{$\begin{array}{c}\text { PORTARIA N }^{\circ} \\
36 / 90\end{array}$} & \multirow{3}{*}{$\begin{array}{c}\text { PORTARIAS } \\
N^{\circ} 1469 / 00 / \\
N^{\circ} 518 / 04 \\
\end{array}$} & \multicolumn{3}{|c|}{ PADRÃO DE POTABILIDADE } & \multirow{2}{*}{\multicolumn{3}{|c|}{${ }^{* * S S}-293$}} & \multirow{2}{*}{\multicolumn{3}{|c|}{$\begin{array}{l}\text { PADRÃO DE QUALIDADE AMBIENTAL } \\
\text { CONAMA No }^{\circ} 20 / 86 \\
\end{array}$}} \\
\hline & & & & D. ESTADUAL/SP & OMS & EPA & & & & & & \\
\hline & & & & Nº12.486/78 & 1995 & 2003 & I & II & III & CLASSE 1 & Classe 2 & CLASSE 3 \\
\hline \multicolumn{13}{|l|}{ I- Físicos Organolépticos } \\
\hline Cor & $\mathrm{UH}^{(1)}$ & 5 & 15 & $10-20$ & 15 & 15 & $\leq 5$ & $5<x \leq 15$ & $>15$ & Natural & $\leq 75$ & $\leq 75$ \\
\hline Odor & - & n. o. & n.o. & Isento / livr. cloro & - & $3^{(11)}$ & n. 0. & n.o. & n. $o$. & - & - & - \\
\hline Sabor & - & n. o. & n.o. & - & - & - & n. o. & n.o. & n. 0. & - & - & - \\
\hline Turbidez & $\mathrm{UT}^{(2)}$ & 1 & 1 & $2-5$ & 5 & 5 & $\leq 1$ & $1<x \leq 5$ & $>5$ & $\leq 40$ & $\leq 100$ & $\leq 100$ \\
\hline Temperatura & ${ }^{\circ} \mathrm{C}$ & - & - & - & - & - & - & - & - & - & - & - \\
\hline $\mathrm{pH}$ & - & $6,5-8,5$ & $6,0-9,5$ & $5,0-9,0$ & $<8,5$ & $6,5-8,5$ & $6,5 / 8,5$ & $6,0 / 10$ & $6,0 / 10$ & $6.0-9.0$ & $6.0-9.0$ & $6.0-9.0$ \\
\hline Condutividade $\left(20^{\circ} \mathrm{C}\right)$ & $\mu \mathrm{Scm}^{-1}$ & - & - & - & - & - & - & - & - & - & - & - \\
\hline Aspecto & - & - & - & Límpido & - & - & - & - & - & - & - & - \\
\hline Mat. flutuantes, inc. esp. não naturais & - & - & - & - & - & - & - & - & - & v. a. & v. a. & v. a. \\
\hline Óleo e graxas & - & - & - & - & - & - & - & - & - & v. a. & v. a. & v. a. \\
\hline Sub. que comuniquem gosto ou odor & - & - & - & - & - & - & - & - & - & v. a. & v. a. & v. a. \\
\hline Corantes artificiais & - & - & - & - & - & - & - & - & - & v. a. & $-(8)$ & $-(8)$ \\
\hline Sub. que formem depósitos objetáveis & - & - & - & - & - & - & - & - & - & v. a. & v. a. & v. a. \\
\hline \multicolumn{13}{|l|}{ II - Químicos } \\
\hline$O D$ & $\mathrm{mg} / \mathrm{L} \mathrm{O} 2$ & - & - & - & - & - & - & - & - & $\geq 6,0$ & $\geq 5,0$ & $\geq 4,0$ \\
\hline$D B O_{5}$ à $20^{\circ} \mathrm{C}$ & $\mathrm{mg} / \mathrm{L} \mathrm{O}_{2}$ & - & - & - & - & - & - & - & - & $\leq 3,0$ & $\leq 5,0$ & $\leq 10,0$ \\
\hline$D Q O$ & $\mathrm{mg} / \mathrm{L} \mathrm{O}_{2}$ & - & - & - & - & - & - & - & - & - & - & - \\
\hline \multicolumn{13}{|l|}{ Compostos Inorgânicos } \\
\hline Antimônio & $\mathrm{mg} / \mathrm{L}$ & - & 0,005 & - & 0,005 & 0,006 & - & - & - & - & - & - \\
\hline Arsênio & $\mathrm{mg} / \mathrm{L}$ & 0,05 & 0,01 & 0,05 & 0,01 & 0,01 & - & - & - & 0,05 & 0,05 & 0,05 \\
\hline Bário & $\mathrm{mg} / \mathrm{L}$ & 1,0 & 0,7 & 1,0 & 0,7 & 2,0 & - & - & - & 1,0 & 1,0 & 1,0 \\
\hline Berílio & $\mathrm{mg} / \mathrm{L}$ & - & - & - & - & 0,004 & - & - & - & 0,1 & 0,1 & 0,1 \\
\hline Boro & $\mathrm{mg} / \mathrm{L}$ & - & - & - & 0,3 & & - & - & - & 0,75 & 0,75 & 0,75 \\
\hline Bromato & $\mathrm{mg} / \mathrm{L}$ & - & 0,025 & - & 0,025 & 0.01 & - & - & - & & & \\
\hline Cádmio & $\mathrm{mg} / \mathrm{L}$ & 0,005 & 0,005 & 0,01 & 0,003 & 0,005 & - & - & - & 0,001 & 0,001 & 0,01 \\
\hline Chumbo & $\mathrm{mg} / \mathrm{L}$ & 0,05 & 0,01 & 0,05 & 0,01 & 0,015 & - & - & - & 0,03 & 0,03 & 0,03 \\
\hline Cianetos & $\mathrm{mg} / \mathrm{L}$ & 0,1 & 0,07 & 0,2 & 0,07 & 0,2 & - & - & - & 0,01 & 0,01 & 0,2 \\
\hline Cromo hexavalente & $\mathrm{mg} / \mathrm{L}$ & - & - & 0,05 & - & - & - & - & - & 0,05 & 0,05 & 0,05 \\
\hline Cromo total & $\mathrm{mg} / \mathrm{L}$ & 0,05 & 0,05 & - & 0,05 & 0,1 & - & - & - & - & - & - \\
\hline Cromo trivalente & $\mathrm{mg} / \mathrm{L}$ & - & - & - & - & - & - & - & - & 0,5 & 0,5 & 0,5 \\
\hline Clorito & $\mathrm{mg} / \mathrm{L}$ & - & 0,2 & - & 0,2 & 1,0 & - & - & - & - & - & - \\
\hline Cloro residual & $\mathrm{mg} / \mathrm{L}$ & - & $3\left(\mathrm{NH}_{2} \mathrm{Cl}\right)$ & 0,3 & $0,6-1,0$ & 4,0 & $>0.2$ & $>0.2$ & $<0,2$ & 0,01 & 0,01 & - \\
\hline Cloro residual livre & $\mathrm{mg} / \mathrm{L}$ & $>0,2$ & 5,0 & - & - & 4,0 & $\geq 2,0$ & $\geq 2,0$ & - & - & - & - \\
\hline Cobalto & $\mathrm{mg} / \mathrm{L}$ & - & - & - & - & - & - & - & - & 0,2 & 0,2 & 0,2 \\
\hline
\end{tabular}


TABELA A - Parâmetros de qualidade de água de legislações Federais, do Estado de São Paulo e Internacionais.

\begin{tabular}{|c|c|c|c|c|c|c|c|c|c|c|c|c|}
\hline \multirow{4}{*}{ PARÂMETROS } & & \multicolumn{8}{|c|}{ Parâmetros de Qualidade de Água - Valores Máximos Permissíveis } & \multirow{2}{*}{\multicolumn{3}{|c|}{ PADRÃO DE QUALIDADE AMBIENTAL }} \\
\hline & \multirow{3}{*}{ UNIDADES } & \multirow{3}{*}{$\begin{array}{c}\text { PORTARIA No } \\
36 / 90\end{array}$} & \multirow{3}{*}{$\begin{array}{c}\text { PORTARIAS } \\
\text { No }^{0} 1469 / 00 / \\
N^{0} 518 / 04\end{array}$} & \multicolumn{3}{|c|}{ PADRÃO DE POTABILIDADE } & & & & & & \\
\hline & & & & D. ESTADUAL/SP & OMS & EPA & \multicolumn{3}{|c|}{ **SS-293 } & \multicolumn{3}{|c|}{ CONAMA No 20/86 } \\
\hline & & & & N¹2.486/78 & 1995 & 2003 & I & $\|$ & III & CLASSE 1 & CLASSE 2 & CLASSE 3 \\
\hline Estanho & $\mathrm{mg} / \mathrm{L}$ & - & - & - & - & - & - & - & - & 2,0 & 2,0 & 2,0 \\
\hline Fluoretos & $\mathrm{mg} / \mathrm{L}$ & $0,6-0,7$ & 1,5 & 1,0 & 1,5 & 4,0 & $0,6 / 08$ & $0,6 / 08$ & $0,6 / 1,0$ & 1,4 & 1,4 & 1,4 \\
\hline Fosfato total & $\mathrm{mg} / \mathrm{L}$ & - & - & - & - & - & - & - & - & 0,025 & 0,025 & 0,025 \\
\hline Lítio & $\mathrm{mg} / \mathrm{L}$ & - & - & - & - & - & - & - & - & 2,5 & 2,5 & 2,5 \\
\hline Mercúrio & $\mathrm{mg} / \mathrm{L}$ & 0,001 & 0,001 & - & 0,001 & 0,002 & - & - & - & 0,0002 & 0,0002 & 0,002 \\
\hline Níquel & $\mathrm{mg} / \mathrm{L}$ & - & - & - & - & - & - & - & - & 0,025 & 0,025 & 0,025 \\
\hline Nitratos (como N) & $\mathrm{mg} / \mathrm{L}$ & 10,0 & 10,0 & 10,0 & 50,0 & 10,0 & - & - & - & 10,0 & 10,0 & 10,0 \\
\hline Nitritos (como N) & $\mathrm{mg} / \mathrm{L}$ & - & 1,0 & - & 3,0 & 1,0 & - & - & - & 1,0 & 1,0 & 1,0 \\
\hline Níquel & $\mathrm{mg} / \mathrm{L}$ & - & - & - & - & - & - & - & - & - & - & - \\
\hline Oxigênio consumido & $\mathrm{mg} / \mathrm{L}$ & - & - & 2,5 & - & - & - & - & - & - & - & - \\
\hline Potássio & $\mathrm{mg} / \mathrm{L}$ & - & - & - & - & - & - & - & - & - & - & - \\
\hline Prata & $\mathrm{mg} / \mathrm{L}$ & 0,05 & - & - & - & 0,10 & - & - & - & 0,01 & 0,01 & 0,05 \\
\hline Selênio & $\mathrm{mg} / \mathrm{L}$ & 0,01 & 0,01 & 0,01 & 0,01 & 0,05 & - & - & - & 0,01 & 0,01 & 0,01 \\
\hline Tálio & $\mathrm{mg} / \mathrm{L}$ & - & - & - & - & 0,002 & - & - & - & - & - & - \\
\hline Urânio total & $\mathrm{mg} / \mathrm{L}$ & - & - & - & - & 0,03 & - & - & - & 0,02 & 0,02 & 0,02 \\
\hline Vanádio & $\mathrm{mg} / \mathrm{L}$ & - & - & - & - & - & - & - & - & 0,1 & 0,1 & 0,1 \\
\hline \multicolumn{13}{|l|}{ Compostos Orgânicos } \\
\hline Acrilamida & $\mu \mathrm{g} / \mathrm{L}$ & - & 0,5 & - & 0,5 & 0,5 & - & - & - & - & - & - \\
\hline Alaclor* & $\mu \mathrm{g} / \mathrm{L}$ & - & 20,0 & - & 20,0 & 2,0 & - & - & - & - & - & - \\
\hline Aldrin e Diedrin* & $\mu \mathrm{g} / \mathrm{L}$ & 0,03 & 0,03 & - & 0,03 & - & - & - & - & $0,01 / 0,005^{(9)}$ & $0,01 / 0,005^{(9)}$ & $0,01 / 0,005^{(9)}$ \\
\hline Atrazina* & $\mu \mathrm{g} / \mathrm{L}$ & - & 2,0 & - & 2,0 & 3,0 & - & - & - & - & - & - \\
\hline Bentazona* & $\mu \mathrm{g} / \mathrm{L}$ & - & 300 & - & 30,0 & - & - & - & - & - & - & - \\
\hline Benzeno & $\mu \mathrm{g} / \mathrm{L}$ & 10,0 & 5,0 & - & 10,0 & 5,0 & - & - & - & 10,0 & 10,0 & 10,0 \\
\hline Benzo-a-pireno & $\mu \mathrm{g} / \mathrm{L}$ & 0,01 & 0,7 & - & 0,7 & 0,2 & - & - & - & 0,01 & 0,01 & 0,01 \\
\hline Bifenilas policloradas (BCP's) & $\mu \mathrm{g} / \mathrm{L}$ & - & - & - & - & 0,5 & - & - & - & 0,001 & 0,001 & 0,001 \\
\hline Carbaril * & $\mu \mathrm{g} / \mathrm{L}$ & - & - & - & - & - & - & - & - & 0,02 & 0,02 & 70,0 \\
\hline Clordano (isômeros) ${ }^{\star}$ & $\mu \mathrm{g} / \mathrm{L}$ & 0,3 & 0,2 & - & 0,2 & 2,0 & - & - & - & 0,04 & 0,04 & 0,3 \\
\hline Cloreto de vinila & $\mu \mathrm{g} / \mathrm{L}$ & - & 5 & - & 5,0 & 2,0 & - & - & - & - & - & - \\
\hline Clorobenzenos & $\mu \mathrm{g} / \mathrm{L}$ & $0,1-0,3$ & $120^{(4)}$ & - & $20-1000$ & 100 & - & - & - & - & - & - \\
\hline Clorofenóis & $\mu \mathrm{g} / \mathrm{L}$ & 0,1 & - & - & $0,1-1,0$ & - & - & - & - & - & - & - \\
\hline 1,2 Dicloroetano & $\mu \mathrm{g} / \mathrm{L}$ & 10,0 & 10,0 & - & 30,0 & 5,0 & - & - & - & 10,0 & 10,0 & 10,0 \\
\hline 1,1 Dicloroeteno & $\mu \mathrm{g} / \mathrm{L}$ & 0,3 & 30,0 & - & 30,0 & - & - & - & - & 0,3 & 0,3 & 0,3 \\
\hline $2,4 \mathrm{D}^{*}$ & $\mu \mathrm{g} / \mathrm{L}$ & 100 & 30,0 & - & 30,0 & 70,0 & - & - & - & 4,0 & 4,0 & 20 \\
\hline Diclorometano & $\mu \mathrm{g} / \mathrm{L}$ & - & 20,0 & - & 20,0 & 5,0 & - & - & - & - & - & - \\
\hline DDT (isômeros)* & $\mu \mathrm{g} / \mathrm{L}$ & 1,0 & 2,0 & - & 2,0 & - & - & - & - & 0,002 & 0,002 & 1,0 \\
\hline Demeton * & $\mu \mathrm{g} / \mathrm{L}$ & - & - & - & - & - & - & - & - & 0,1 & 0,1 & 14,0 \\
\hline Dodecacloro + Nonacloro & $\mu \mathrm{g} / \mathrm{L}$ & - & - & - & - & - & - & - & - & 0,001 & 0,001 & 0,001 \\
\hline Endossulfan * & $\mu \mathrm{g} / \mathrm{L}$ & - & 20,0 & - & - & - & - & - & - & 0,056 & 0,056 & 150 \\
\hline Endrin * & $\mu \mathrm{g} / \mathrm{L}$ & 0,2 & 0,6 & - & - & 2,0 & - & - & - & 0,004 & 0,004 & 0,2 \\
\hline Estireno & $\mu \mathrm{g} / \mathrm{L}$ & - & 20,0 & - & 20,0 & 100 & - & - & - & 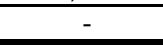 & - & - \\
\hline
\end{tabular}


TABELA A - Parâmetros de qualidade de água de legislações Federais, do Estado de São Paulo e Internacionais.

Parâmetros de Qualidade de Água - Valores Máximos Permissíveis

\begin{tabular}{|c|c|c|c|c|c|c|c|c|c|c|c|c|}
\hline \multicolumn{13}{|c|}{ Parâmetros de Qualidade de Água - Valores Máximos Permissíveis } \\
\hline \multirow{3}{*}{ PARÂMETROS } & \multirow{3}{*}{ UNIDADES } & \multirow{3}{*}{$\begin{array}{l}\text { PORTARIA No } \\
\quad 36 / 90\end{array}$} & \multirow{3}{*}{$\begin{array}{l}\text { PORTARIAS } \\
\text { NN} 1469 / 00 /^{\circ} \text { No518/04 }^{\circ}\end{array}$} & \multicolumn{3}{|c|}{ PADRÃO DE POTABILIDADE } & \multirow{2}{*}{\multicolumn{3}{|c|}{ **SS-293 }} & \multirow{2}{*}{\multicolumn{3}{|c|}{$\begin{array}{c}\text { PADRÃO DE QUALIDADE AMBIENTAL } \\
\text { CONAMA No } 20 / 86\end{array}$}} \\
\hline & & & & D. ESTADUAL/SP & OMS & EPA & & & & & & \\
\hline & & & & 2.486 & 1995 & 2003 & I & II & III & CLASSE 1 & CLASSE 2 & CLASSE 3 \\
\hline Fenol & $\mu \mathrm{g} / \mathrm{L}$ & 0,1 & $-?$ & - & - & - & - & - & - & 1,0 & 1,0 & 300 \\
\hline Glifosato* & $\mu \mathrm{g} / \mathrm{L}$ & - & 500 & - & - & 700 & - & - & - & - & - & - \\
\hline Gution $^{*}$ & $\mu \mathrm{g} / \mathrm{L}$ & - & - & - & - & - & - & - & - & 0,005 & 0,005 & 0,005 \\
\hline Heptacloro + hept. Epóxido* & $\mu \mathrm{g} / \mathrm{L}$ & 0.1 & 0,03 & - & 0,03 & $0,4 / 0,2^{(10)}$ & - & - & - & $0,01 / 0,01^{(10)}$ & $0,01 / 0,01^{(10)}$ & $0,1 / 0,1^{(10)}$ \\
\hline Hexaclorobenzeno * & $\mu \mathrm{g} / \mathrm{L}$ & 0,01 & 1,0 & - & 0,1 & 1,0 & - & - & - & - & - & - \\
\hline Lindano $(\gamma-\mathrm{HCH})^{*}$ & $\mu \mathrm{g} / \mathrm{L}$ & 3,0 & 2,0 & - & 2,0 & 0,2 & - & - & - & 0,02 & 0,02 & 3,0 \\
\hline Malation* $^{*}$ & $\mu \mathrm{g} / \mathrm{L}$ & - & - & - & - & - & - & - & - & 0,1 & 0,01 & 100 \\
\hline Metolacloro * & $\mu \mathrm{g} / \mathrm{L}$ & - & 10,0 & - & 10,0 & - & - & - & - & - & - & - \\
\hline Metoxicloro * & $\mu \mathrm{gg} / \mathrm{L}$ & 30,0 & 20,0 & - & 20,0 & 4,0 & - & - & - & 0,03 & 0,03 & 30 \\
\hline Molinato * & $\mu \mathrm{g} / \mathrm{L}$ & - & 6,0 & - & 6,0 & - & - & - & - & - & - & - \\
\hline Organofosf. e Carbamatos ${ }^{*}$ & $\mu \mathrm{g} / \mathrm{Lp}$ parat. & - & - & - & - & - & - & - & - & 10,0 & 10,0 & 10,0 \\
\hline Paration * & $\mu \mathrm{g} / \mathrm{L}$ & - & - & - & - & - & - & - & - & 0,04 & 0,04 & 35,0 \\
\hline Pendimetalina* & $\mu \mathrm{g} / \mathrm{L}$ & - & 20,0 & - & 20,0 & - & - & - & - & - & - & - \\
\hline Pentaclorofenol $^{*}$ & $\mu \mathrm{g} / \mathrm{L}$ & 10,0 & 9,0 & - & 9,0 & 1,0 & - & - & - & 10,0 & 10,0 & 10,0 \\
\hline Permetrina* & $\mu \mathrm{g} / \mathrm{L}$ & - & 20,0 & - & 20,0 & - & - & - & - & - & - & - \\
\hline Propanil * & $\mu \mathrm{g} / \mathrm{L}$ & - & 20 & - & 20,0 & - & - & - & - & - & - & - \\
\hline Simazina * & $\mu \mathrm{g} / \mathrm{L}$ & - & 2,0 & - & 2,0 & 4,0 & - & - & - & - & - & - \\
\hline Tetracloreto de carbono & $\mu \mathrm{g} / \mathrm{L}$ & 3,0 & 2,0 & - & 2,0 & - & - & - & - & 3,0 & 3,0 & 3,0 \\
\hline Tetracloroeteno & $\mu \mathrm{g} / \mathrm{L}$ & 10,0 & 40,0 & - & 40,0 & 5,0 & - & - & - & 10,0 & 10,0 & 10,0 \\
\hline Toxafeno*? & $\mu \mathrm{g} / \mathrm{L}$ & 5,0 & - & - & - & 3,0 & - & - & - & 0,01 & 0,01 & 5,0 \\
\hline Triclorobenzeno & $\mu \mathrm{g} / \mathrm{L}$ & - & 20,0 & - & 20,0 & 70,0 & - & - & - & - & - & - \\
\hline Tricloetenos & $\mu \mathrm{g} / \mathrm{L}$ & 30,0 & 70,0 & - & 70,0 & 5,0 & - & - & - & 30,0 & 30,0 & 30,0 \\
\hline $\mathrm{I}, \mathrm{I}, \mathrm{I}$, Tricloroetano & $\mu \mathrm{g} / \mathrm{L}$ & - & - & - & 2000 & 200 & - & - & - & - & - & - \\
\hline 2,4,6 Triclorofenol & $\mu \mathrm{g} / \mathrm{L}$ & 10,0 & 200 & - & $2,0-300$ & - & - & - & - & 10,0 & 10,0 & 10,0 \\
\hline Trihalometanos & $\mu \mathrm{g} / \mathrm{L}$ & $100^{(3)}$ & 100 & - & 200 & 80,0 & - & - & - & - & - & - \\
\hline Trifluralina * & $\mu \mathrm{g} / \mathrm{L}$ & - & 20 & - & 20,0 & - & - & - & - & - & - & - \\
\hline Pesticidas - individual & $\mu \mathrm{g} / \mathrm{L}$ & - & - & - & - & - & - & - & - & - & - & - \\
\hline Pesticidas - total & $\mu \mathrm{g} / \mathrm{L}$ & - & - & - & - & - & - & - & - & - & - & - \\
\hline $2,4,5, \mathrm{TP}$ & $\mu \mathrm{g} / \mathrm{L}$ & - & - & - & - & 50,0 & - & - & - & 10,0 & 10,0 & 10,0 \\
\hline $2,4,5 \mathrm{~T}$ & $\mu \mathrm{g} / \mathrm{L}$ & - & - & - & 9,0 & - & - & - & - & 2,0 & 2,0 & 2,0 \\
\hline \multicolumn{13}{|l|}{ Afetam a Qualidade Organoléptica } \\
\hline Alumímio & $\mathrm{mg} / \mathrm{L}$ & $0,2^{(3)}$ & 0,2 & - & 0,2 & $0,05-0,2$ & - & - & - & 0,1 & 0,1 & 0,1 \\
\hline Amônia (como NH${ }_{3}$ ) & $\mathrm{mg} / \mathrm{L}$ & - & 1,5 & - & 1,5 & - & - & - & - & 0,02 & 0,02 & - \\
\hline Surfactantes (LAS) & $\mathrm{mg} / \mathrm{L}$ & 0,2 & 0,5 & - & - & 0,5 & - & - & - & 0,5 & 0,5 & 0,5 \\
\hline Cloretos & $\mathrm{mg} / \mathrm{L}$ & 250 & 250 & 250 & 250 & 250 & - & - & - & 250 & 250 & 250 \\
\hline Cobre & $\mathrm{mg} / \mathrm{L}$ & 1,0 & 2,0 & 1,0 & 1,0 & 1,0 & - & - & - & 0,02 & 0,02 & 0,5 \\
\hline Dureza total $\left(\mathrm{como} \mathrm{CaCO}_{3}\right)$ & $\mathrm{mg} / \mathrm{L}$ & 500 & 500 & - & 500 & - & - & - & - & - & - & - \\
\hline Etilbenzeno & $\mathrm{mg} / \mathrm{L}$ & - & 0,2 & - & $0,002-0,2$ & - & - & - & - & - & - & - \\
\hline
\end{tabular}


TABELA A - Parâmetros de qualidade de água de legislações Federais, do Estado de São Paulo e Internacionais.

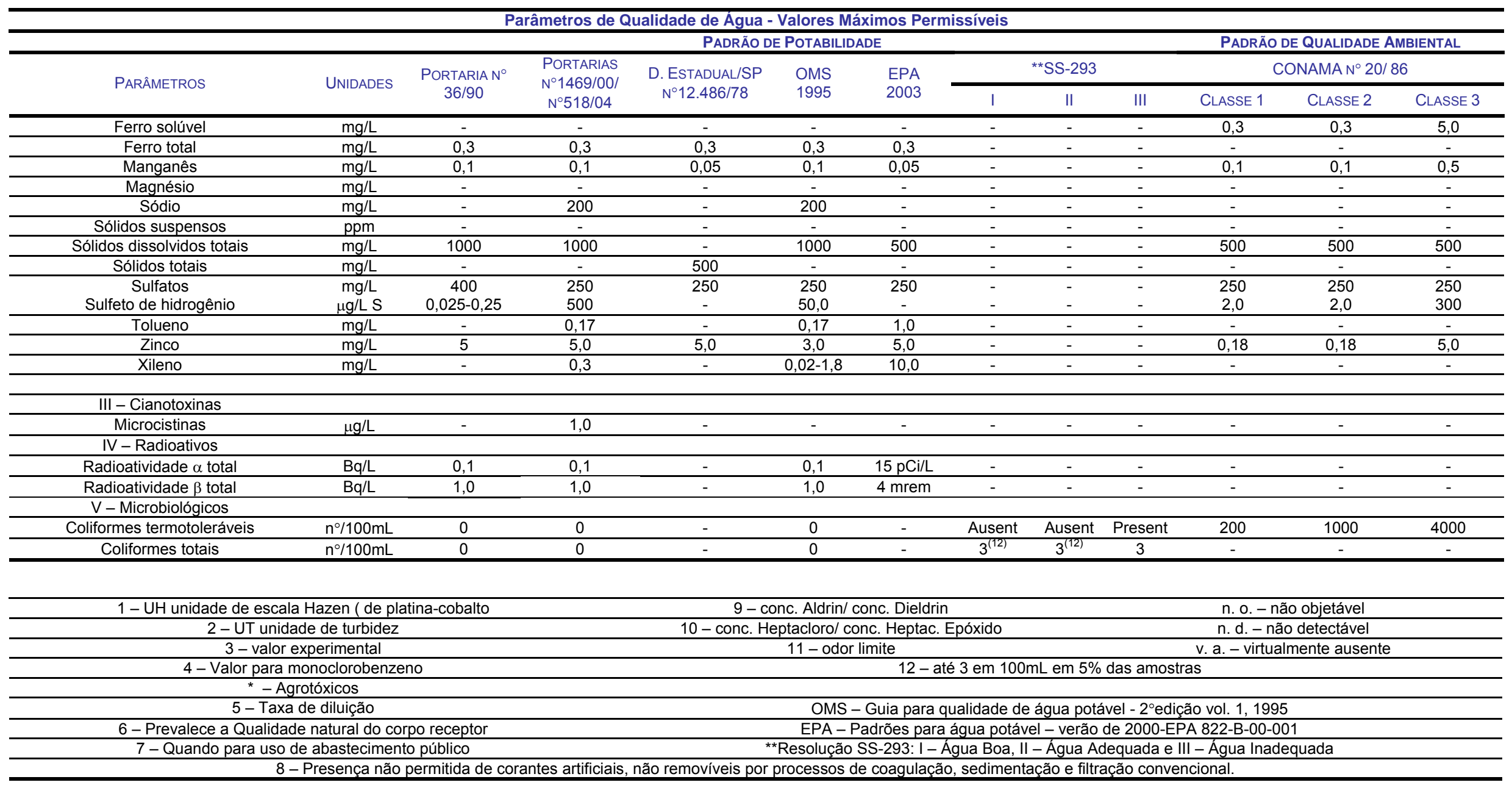


APENDICE B - Características, aplicação e classificação dos agrotóxicos quanto à toxidade (Larini, 1999; Tomlin, 1994; Toxnet, 2004; Anvisa, 2004; Hayes, 1997; Compêndio de defensivos agrícolas,1996; Rodrigues, 1998).

\title{
ALDICARBE
}

\begin{abstract}
Atuação: Inseticida, acaricida e nematicida sistêmico e age com o contato e no estomago. Inibe a Acetilcolinesterase.
\end{abstract}

Grupo Químico: carbamatos

Nome IUPAC: 2-methyl-2-(tiometil)-

propionaldeido-O-(metilcarbamoil)oxima.

№ CAS: $116-06-3$

Nome CAS: 2-methyl-2-(tiometil)-propanal-

O-[(metilamino)carbonil]oxima.

Formula Molecular: $\mathrm{C}_{7} \mathrm{H}_{14} \mathrm{~N}_{2} \mathrm{O}_{2} \mathrm{~S}$

\section{Destino no meio ambiente:}

Peso molecular: 190,3; forma: cristal Animal: Absorvido rápida e completamente em incolor; ponto de fusão: $98-100^{\circ} \mathrm{C}$;

pressão de vapor: $1,28.10^{-7} \mathrm{~atm}\left(20^{\circ} \mathrm{C}\right)$; densidade: $1,195 \mathrm{gL}^{-1}\left(20^{\circ} \mathrm{C}\right)$;

solubilidade: $4,94 \mathrm{gL}^{-1}\left(\mathrm{pH} 7.20^{\circ} \mathrm{C}\right)$ em água, $350 \mathrm{gkg}^{-1}$ em acetona, $300 \mathrm{gkg}^{-1}$ em diclorometano; $150 \mathrm{gkg}^{-1}$ em benzeno; $150 \mathrm{gkg}^{-1}$ em xileno (todos a $25^{\circ} \mathrm{C}$ ); praticamente insolúvel em heptano e óleo mineral;

estabilidade: estável em meio neutro, ácido e fracamente alcalino. Decompõe-se acima de $100^{\circ} \mathrm{C}$ e hidrolisa em álcalis concentrados.

\section{Uso autorizado no Brasil:}

Aplicado no solo das culturas de: algodão, batata, café, citros, feijão; e no pseudocaule da banana. ratos, cachorros e vacas. Mais de $80 \%$ é excretado pela urina em 24 horas e mais de 96\% em 3-4 dias.

Plantas: O átomo de enxofre é oxidado para os grupos sulfóxidos e sulfona. $\mathrm{O}$ sulfóxido é altamente solúvel e age sistematicamente na planta, além de ser 10-20 vezes mais ativo que o próprio aldicarbe na inibição da Acetilcolinesterase.

Solo e água: No solo, os átomos de enxofre são oxidados a grupos sulfóxido e sulfona. A degradação leva a formação de oximas, nitrilas, amidas, ácidos e álcoois.

\section{Toxicologia:}

Classe la; segundo a IARC é classificado como um agrotóxico do Grupo 3 - não classificado como carcinogênico.

\section{Fórmula Estrutural:}<smiles>CNC(=O)O/N=C/C(C)(C)SC</smiles>

$\mathrm{LD}_{50} \mathrm{p} /$ ratos $\left(\mathrm{mgkg}^{-1}\right)$ : 0,46-1,23.

VMP (Valor Máximo Permissível)-(EPA): $10 \mu \mathrm{gL}^{-1}$ e não consta na Portaria $n^{\circ} 518 / M S / 04$. 
Atuação: herbicida seletivo sistêmico absorvido, principalmente, através das raízes, mas também pelas folhagens. Inibe a fotossíntese e interfere em outros processos enzimáticos.

Grupo Químico: triazinas

Fórmula Estrutural:

Nome IUPAC: 6 -cloro- $\mathrm{N}^{2}$-etil- $\mathrm{N}^{4}$-isopropil-

1,3,5-triazina-2,4-diamina.

№ CAS: $1912-24-9$

Nome CAS: 6-cloro-N-etil-N'-(1 metiletil)-

1,3,5-triazina-2,4-diamina.<smiles>CCNc1nc(Cl)nc(NC(C)C)n1</smiles>

Formula Molecular: $\mathrm{C}_{8} \mathrm{H}_{14} \mathrm{CIN}_{5}$

\section{Propriedades Físico-químicas:}

Peso molecular: 215,7;

forma: pó incolor;

ponto de fusão: $175,8^{\circ} \mathrm{C}$;

pressão de vapor: $3,83.10^{-10} \mathrm{~atm}\left(25^{\circ} \mathrm{C}\right)$;

densidade: $1,187 \mathrm{gL}^{-1}\left(20^{\circ} \mathrm{C}\right)$;

solubilidade: $33 \mathrm{mgL}^{-1}\left(20^{\circ} \mathrm{C}\right)$ em água, $15 \mathrm{gL}^{-}$

${ }^{1}$ em metanol, $24 \mathrm{gL}^{-1}$ etil acetona, $31 \mathrm{gL}^{-1} \mathrm{em}$

acetona, $28 \mathrm{gL}^{-1}$ em diclorometano; $6,0 \mathrm{gL}^{-1}$

em tolueno; $0,11 \mathrm{gL}^{-1}$ em n-hexano; $8,7 \mathrm{gL}^{-1}$

em n-octanol (todos a $25^{\circ} \mathrm{C}$ );

estabilidade: estável em meio neutro, fracamente ácido e alcalino. Rapidamente hidrolisado para os hidróxidos derivados em meio fortemente ácido ou alcalino e meio neutro a $70^{\circ} \mathrm{C}$;

pKa: 1,7 .

\section{Destino no meio ambiente:}

Animal: Em mamíferos a atrazina é rápida e completamente metabolisada. $\bigcirc$ principal metabólito é diaminoclorotriazina, o qual é rapidamente conjugado com a glutationa. Mais de $50 \%$ da dose é elimanada pela urina e, aproximadamente, $33 \%$ nas fezes em $42 \mathrm{~h} 00$.

Plantas: Em plantas tolerantes, a atrazina é metabolisada, rapidamente, a hidroxiatrazina e os aminoácidos conjugados, ainda a decomposição da hidroxiatrazina pela degradação da cadeia cíclica e a do hidrolises dos aminoácidos resultantes do anel, junto com a formação do dióxido de carbono. Em plantas sensíveis, ocorre o acúmulo inalterado da atrazina levando a clorose e morte.

Solo e água: Sob qualquer condição os maiores metabólitos são desetilatrazina e hidroxiatrazina.

No campo o $\mathrm{DT}_{50}$ da atrazina é 35-50 dias, mas pode ser maior sob condições frias e secas. Sob as condições da água subterrânea o $\mathrm{DT}_{50}$ varia de 105 a mais de 200 dias.

\section{Toxicologia:}

Classe III; segundo a IARC é classificado como um agrotóxico do Grupo 2B - possível carcinogênico 
cana-de-açúcar, milho, pinus, seringueira, ao Homem.

sisal e sorgo.

A atrazina apresenta atividade mutagênica, avaliada em testes com Salmonella typhimurium.

$\mathrm{LD}_{50} \mathrm{p} /$ ratos $\left(\mathrm{mgkg}^{-1}\right)$ : 1900-3000.

VMP (Valor Máximo Permissível): $3 \mu \mathrm{gL}^{-1}$ (EPA) e

$2 \mu \mathrm{gL}^{-1}$ (Portaria $\left.\mathrm{n}^{\circ} 518 / \mathrm{MS} / 04\right)$

\section{CARBARIL}

Atuação: Inseticida não sistêmico e age com o contato e no estomago. Inibidor fraco da Acetilcolinesterase.

Grupo Químico: carbamatos

Fórmula Estrutural:

Nome IUPAC: 1-naftil metilcarbamato.

№ CAS: $63-25-2$

Nome CAS: 1-naftaenil metilcarbamato.

Formula Molecular: $\mathrm{C} 12 \mathrm{H} 11 \mathrm{NO} 2$<smiles>CNC(=O)Oc1cccc2ccccc12</smiles>

\section{Propriedades Físico-químicas:}

Destino no meio ambiente:

Peso molecular: 201,2;

Animal: Nos mamíferos o carbaril não acumula forma: cristal incolor variando para marrom nos tecidos do corpo, mas é rapidamente claro; metabolisado para substancias não tóxicas, ponto de fusão: $142^{\circ} \mathrm{C}$; pressão de vapor: $4,05.10^{-10} \mathrm{~atm}\left(23,5^{\circ} \mathrm{C}\right)$; densidade: $1,232 \mathrm{gL}^{-1}\left(20^{\circ} \mathrm{C}\right)$; particularmente 1-naftol. Este junto com o ácido glucónico conjugado é eliminado predominantemente pela urina e fezes.

solubilidade: $0,12 \mathrm{gL}^{-1}\left(20^{\circ} \mathrm{C}\right)$ em água, 200 - Plantas: Forma os metabólitos 4-hidróxi-carbaril, $300 \mathrm{gkg}^{-1}$ em acetona, $400-450 \mathrm{gkg}^{-1}$ em 5-hidróxi-carbaril e metilol-carbaril. dimetilformaldeido e em dimetil sulfóxido; $100 \mathrm{gkg}^{-1}$ em e em xileno (todos a $25^{\circ} \mathrm{C}$ ); praticamente insolúvel em heptano e óleo mineral;

estabilidade: estável em meio neutro, e Solo e água: sob condições aeróbicas $1 \mathrm{ppm}$ de carbaril é degradado com uma meia-vida de 7-14 dias em solo arenoso e 14-28 dias em solo argiloso.

fracamente ácido. Hidrolisado em meio alcalino para 1-naftol; $\mathrm{DT}_{50} 12$ dias $(\mathrm{pH} \mathrm{7)}$, $3,2 \mathrm{~h}(\mathrm{pH} 9)$. Estável à luz e ao aquecimento. 


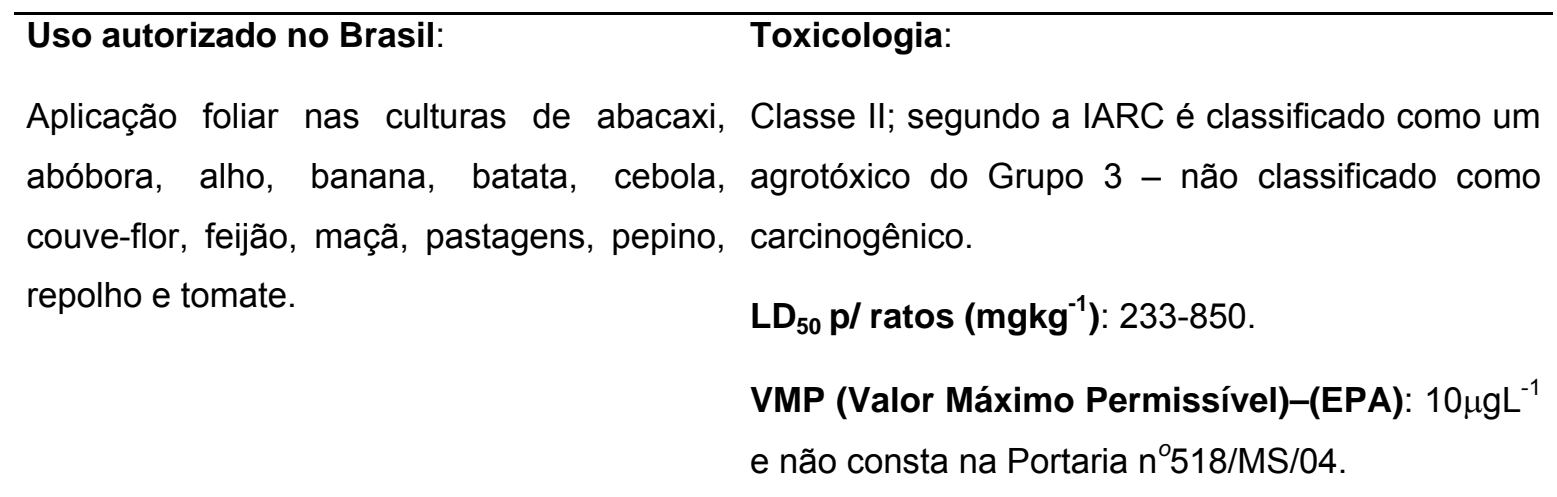

\section{CARBOFURANO}

Atuação: Inseticida sistêmico, acaricida e cupinicida e nematicida age, predominantemente, com o contato e no estomago. Inibidor da Colinesterase.

Grupo Químico: carbamatos Fórmula Estrutural:

Nome IUPAC: 2,3-dihidro-2,2-

dimetilbenzofurano-7-il-metilcarbamato.

№ CAS: $1563-66-2$

Nome CAS: 2,3-dihidro-2,2-dimetil-7-

benzofuranil-metilcarbamato.

Formula Molecular: $\mathrm{C} 12 \mathrm{H} 15 \mathrm{NO} 3$<smiles>CNC(=O)Oc1cccc2c1OC(C)(C)C2</smiles>

\section{Propriedades Físico-químicas:}

Peso molecular: 221,3;

forma: cristal incolor;

ponto de fusão: $142^{\circ} \mathrm{C}$;

pressão de vapor: $3,06.10^{-10} \mathrm{~atm}\left(20^{\circ} \mathrm{C}\right)$;

densidade: $1,18 \mathrm{gL}^{-1}\left(20^{\circ} \mathrm{C}\right)$;

solubilidade: $0,32 \mathrm{gL}^{-1}\left(20^{\circ} \mathrm{C}\right)$ em água, nas urina está na forma de metabólito conjugado.

$>200 \mathrm{gL}^{-1}$ em diclometano, 20-50 $\mathrm{gL}^{-1}$ em Plantas: $O$ carbofurano é rapidamente Isopropanol, $10-20 \mathrm{gL}^{-1}$ em tolueno (todos a metabolisado nos inseticidas 3-hidroxicarbofurano $20^{\circ} \mathrm{C}$ ); e cetocarbofurano.

estabilidade: estável em meio neutro e Solo e água: $\mathrm{DT}_{50} 30-60$ dias no solo. $\mathrm{O}$ ácido. Instável em meio alcalino; decompõe- metabólito mais importante é o $\mathrm{CO}_{2}$ formado pela se $>150^{\circ} \mathrm{C}$. $\mathrm{DT}_{50}\left(22^{\circ} \mathrm{C}\right)>>1$ ano $(\mathrm{pH} 7), 121$ degradação microbiológica dos compostos dias $(\mathrm{pH} 7)$ e 31 dias $(\mathrm{pH} 9)$. fenólicos.

\section{Uso autorizado no Brasil:}

\section{Toxicologia:}

Aplicação no solo nas culturas de algodão, Classe lb. amendoim, arroz, banana, batata, café, LD $_{50}$ p/ ratos $\left(\mathbf{m g k g}^{-1}\right)$ : 5,3-13,2. 
cana-de-açúcar, cenoura, feijão, fumo, milho, VMP (Valor Máximo Permissível)-(EPA): $40 \mu \mathrm{gL}^{-1}$ repolho, tomate e trigo.

e não consta na Portaria n ${ }^{\circ} 518 / \mathrm{MS} / 04$.

Aplicação em sementes de algodão, arroz,

feijão, milho e trigo.

\section{SIMAZINA}

Atuação: herbicida seletivo sistêmico absorvido, principalmente, através das raízes, acumula-se no meristema apical e folhas. Inibidor do transporte elétron fotossintético.

Grupo Químico: triazinas

Nome IUPAC: 6 -cloro- $\mathrm{N}^{2}, \mathrm{~N}^{4}$-dietil-1,3,5-

triazina-2,4-diamina.

№ CAS: $122-34-9$

Nome CAS: 6-cloro-N,N`-dietil-1,3,5-triazina-

2,4-diamina.

Formula Molecular: $\mathrm{C}_{7} \mathrm{H}_{12} \mathrm{CIN}_{5}$

\section{Fórmula Estrutural:}<smiles>CCNc1nc(Cl)nc(NCC)n1</smiles>

\section{Destino no meio ambiente:}

\section{Propriedades Físico-químicas:}

Peso molecular: 201,7;

forma: pó incolor;

ponto de fusão: $225-227^{\circ} \mathrm{C}$ (decompõe-se);

pressão de vapor: $2,902.10^{-11} \mathrm{~atm}\left(25^{\circ} \mathrm{C}\right)$;

densidade: $1,302 \mathrm{gL}^{-1}\left(20^{\circ} \mathrm{C}\right)$;

solubilidade: $\quad 6,2 \mathrm{mgL}^{-1}\left(20^{\circ} \mathrm{C}\right)$ em água, $570 \mathrm{mgL}^{-1}$ em etanol, $1500 \mathrm{mLL}^{-1}$ acetona, $130 \mathrm{mgL}^{-1}$ em tolueno; $3,1 \mathrm{mgL}^{-1}$ em nhexano; $390 \mathrm{mgL}^{-1}$ em n-octanol (todos a $25^{\circ} \mathrm{C}$;

estabilidade: estável em meio neutro, fracamente ácido e alcalino. Rapidamente hidrolisado em meio fortemente ácido ou alcalino.Decompõe-se por irradiação ultravioleta (90\% em 96h);

pKb: 12,3 .
Animal: Em mamíferos, na administração oral, 65$97 \%$ da simazina é eliminada em $24 \mathrm{~h}$. Os principais metabólitos de degradação são desetilsimazina e diaminocloroatrazina.

Plantas: Em plantas tolerantes, a simazina é metabolisada, rapidamente, a 6-hidroxisimazina e os aminoácidos conjugados.Essa sofre degradação por dealquilação da cadeia cíclica e por hidrolise formando os aminoácidos resultantes do anel, junto com a formação do dióxido de carbono. Em plantas sensíveis, ocorre o acúmulo inalterado da simazina levando a clorose e morte.

Solo e água: No solo, a atividade microbiana é responsável pela maior parte da degradação da simazina. $\mathrm{DT}_{50}$ 70-110 dias. A perda por fotodecomposição ou volatilização é insignificante. A penetração no solo ou a lixiviação é muito limitada devido à baixa solubilidade da simazina em água. Após meses da aplicação a maior porção é encontrada a alguns centímetros do solo $(\cong 5 \mathrm{~cm})$. 


\begin{tabular}{|c|c|}
\hline Uso autorizado no Brasil: & Toxicologia: \\
\hline $\begin{array}{l}\text { Aplicação em pré e pós-emergência das } \\
\text { plantas infestantes nas culturas de abacaxi, } \\
\text { banana, cacau, café, cana-de-açúcar, citros, } \\
\text { maçã, milho, pinus, seringueira, sisal, sorgo } \\
\text { e uva. }\end{array}$ & $\begin{array}{l}\text { Classe III; segundo a IARC é classificado como um } \\
\text { agrotóxico do Grupo } 3 \text { - não classificado como } \\
\text { carcinogênico. } \\
\text { O fígado constitui o órgão alvo na ação tóxica da } \\
\text { simazina, durante as exposições prolongadas. } \\
\mathrm{LD}_{50} \mathrm{pl} \text { ratos (mgkg }{ }^{-1} \text { ): }>5000 \text {. } \\
\mathrm{VMP} \text { (Valor Máximo Permissível): } 4 \mu \mathrm{gL}^{-1} \text { (EPA) e } \\
2 \mu \mathrm{gL}^{-1}\left(\text { Portaria } \mathrm{n}^{\circ} 518 / \mathrm{MS} / 04\right)\end{array}$ \\
\hline
\end{tabular}

\section{TRIFLURALINA}

Atuação: herbicida seletivo que atua penetrando na muda da planta atrapalhando a divisão celular e inibindo o desenvolvimento da raiz.

Grupo Químico: dinitroanilinas Fórmula Estrutural:

Nome IUPAC: $\alpha, \alpha, \alpha$-trifluor-2,6-dinitro-

$\mathrm{N}, \mathrm{N}$-dipropil- $p$-toluideno.

№ CAS: $1582-09-8$

Nome CAS: 2,6-dinitro-N,N-dipropil-4(trifluormetil)benzamino.

Formula Molecular: $\mathrm{C}_{13} \mathrm{H}_{16} \mathrm{~F}_{3} \mathrm{~N}_{3} \mathrm{O}_{4}$<smiles>CCCN(CCC)c1c([N+](=O)[O-])cc(C(F)(F)F)cc1[N+](=O)[O-]</smiles>

\section{Propriedades Físico-químicas:}

Peso molecular: 335,3;

forma: cristal amarelo-alaranjado;

ponto de fusão: $48,5-49^{\circ} \mathrm{C}$;

ponto de ebulição: $139-149^{\circ} \mathrm{C}$;

pressão de vapor: $9.38 .10^{-8} \mathrm{~atm}\left(25^{\circ} \mathrm{C}\right)$;

densidade: $1,36 \mathrm{gL}^{-1}\left(22^{\circ} \mathrm{C}\right)$;

solubilidade: $\mathrm{Em}$ água $0,184 \mathrm{mgL}^{-1}(\mathrm{pH} 5)$, $0,221 \mathrm{mgL}^{-1}(\mathrm{pH} 7), 0,189 \mathrm{mgL}^{-1}(\mathrm{pH} 9) . \mathrm{Em}$ acetona, tolueno; clorofórmio, acetonitrila e etil acetato $>1000 \mathrm{gL}^{-1}$ (todos a $25^{\circ} \mathrm{C}$ ). Em hexano; $50-67 \mathrm{gL}^{-1}$ e em metanol 33$40 \mathrm{gL}^{-1}$ (todos a $25^{\circ} \mathrm{C}$ );

estabilidade: estável a temperatura $52^{\circ} \mathrm{C}$.

\section{Destino no meio ambiente:}

Animal: A degradação em animais é como a no solo. $\mathrm{Na}$ administração oral $\cong 70 \%$ é eliminado pela urina e $15 \%$ pelas fezes dentro de $72 \mathrm{~h}$.

Plantas: A degradação em plantas é como a no solo.

Solo e água: Absorvido pelo solo e extremamente resistente a lixiviação. Sofre pequenos movimentos laterais no solo. A degradação é bastante complexa e envolve, principalmente, reações de desalquilação do grupo amino, redução dos grupos nitro para grupos amino, oxidação parcial do grupo trifluormetil para grupo caboxi e degradação subseqüente para fragmentos menores. $\mathrm{DT}_{50}$ 57-126 dias. A duração da atividade residual no solo é 6-8meses. 
Estável a hidrólise em valores de $\mathrm{pH} \mathrm{3,6}$

e $9\left(52^{\circ} \mathrm{C}\right)$.Decompõe-se por irradiação

ultravioleta;

ponto de fulgor: $151^{\circ} \mathrm{C}$.

Uso autorizado no Brasil:

Toxicologia:

Aplicação em pré-emergência das plantas Classe III; segundo a IARC é classificado como um infestantes nas culturas de algodão, alho, agrotóxico do Grupo 3 - não classificado como amendoim, arroz, berinjela, cana-de- carcinogênico.

açúcar, cebola, cenoura, citros, couve,

couve-flor, eucalipto, feijão, feijão-vagem,

$\mathrm{LD}_{50} \mathrm{p} /$ ratos $\left(\mathrm{mgkg}^{-1}\right):>5000$.

girassol, gladíolo, mamona, milho, VMP (Valor Máximo Permissível): $2 \mu \mathrm{gL}^{-1}$ (EPA) e pimentão, pinus, quiabo, repolho, $20 \mu \mathrm{gL}^{-1}$ (Portaria $\left.\mathrm{n}^{\circ} 518 / \mathrm{MS} / 04\right)$

seringueira, rosa, soja e tomate. 
APÊNDICE C - Registro fotográfico para mostrar algumas atividades antrópicas da região.
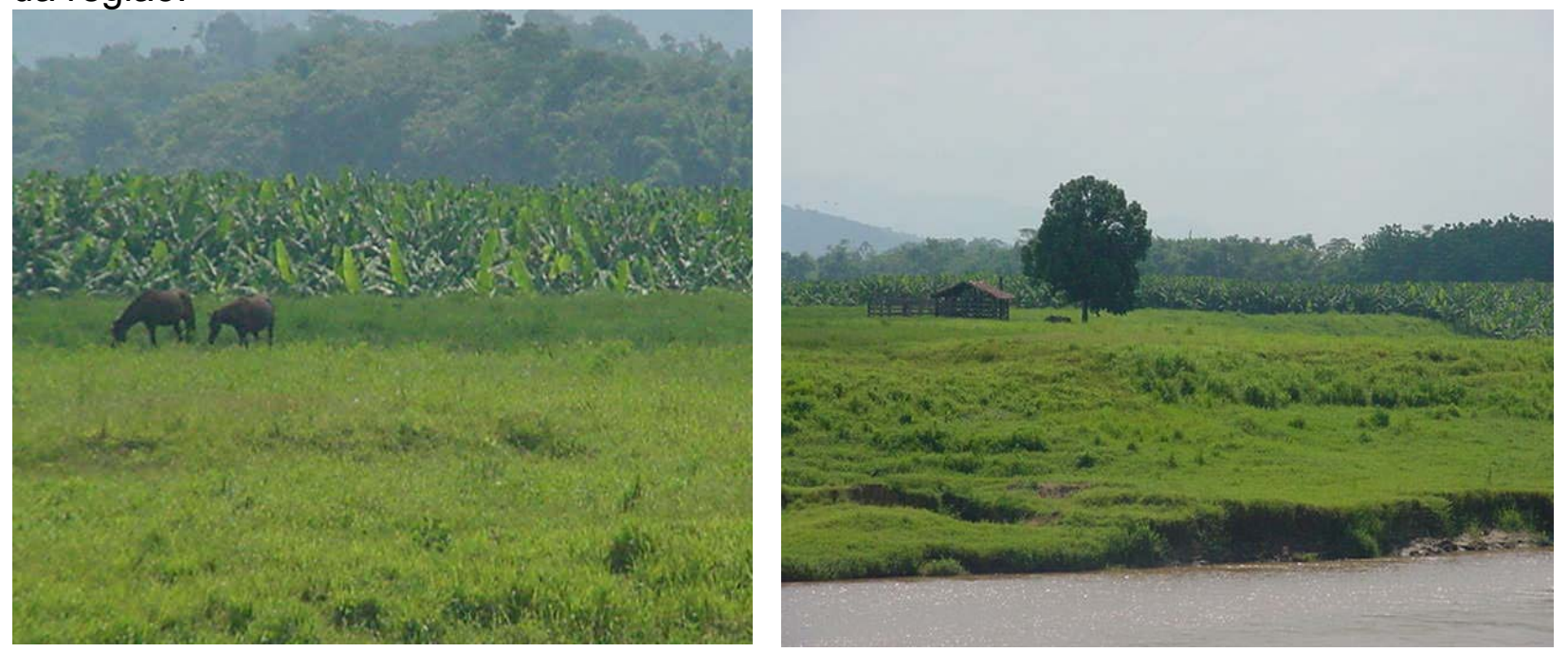

Foto - 1 e Foto - 2: Área de pastagem e de cultivo de banana numa ilha no rio Ribeira a montante da ETA de Eldorado.

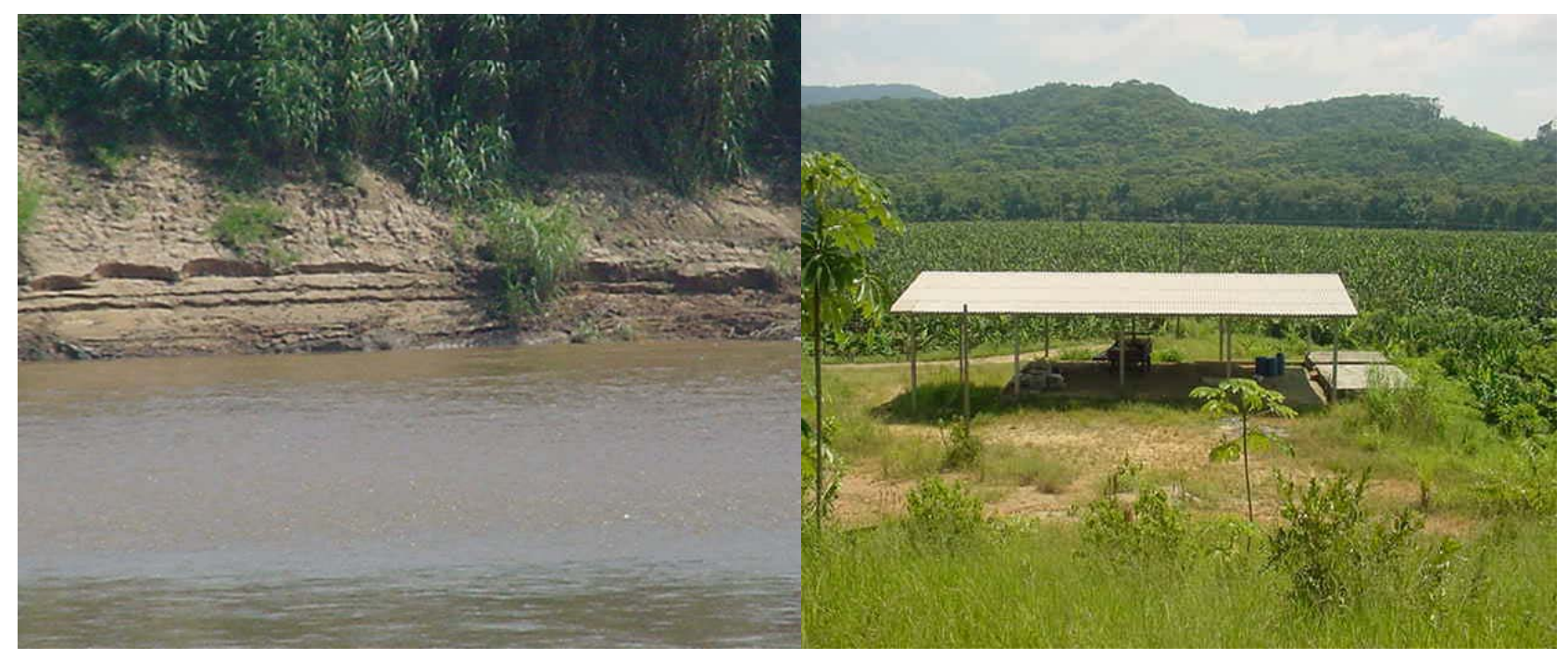

Foto - 3: Erosão de uma das margens do rio Ribeira
Foto -4: Galpão de armazenamento de produtos para agricultura, próximo ao rio Ribeira. 


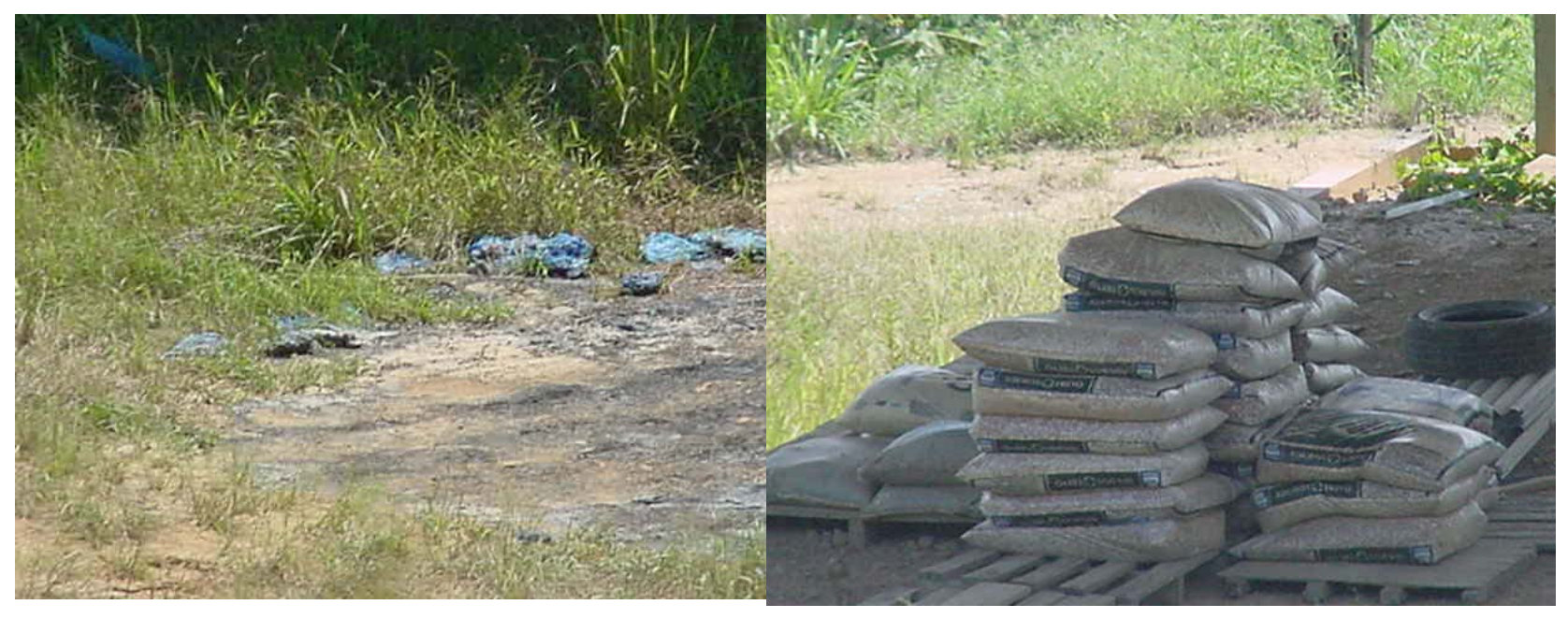

Foto-5 e Foto-6: Próximo ao rio Ribeira de Iguape, em Eldorado, sacos de produtos granulados para agricultura.

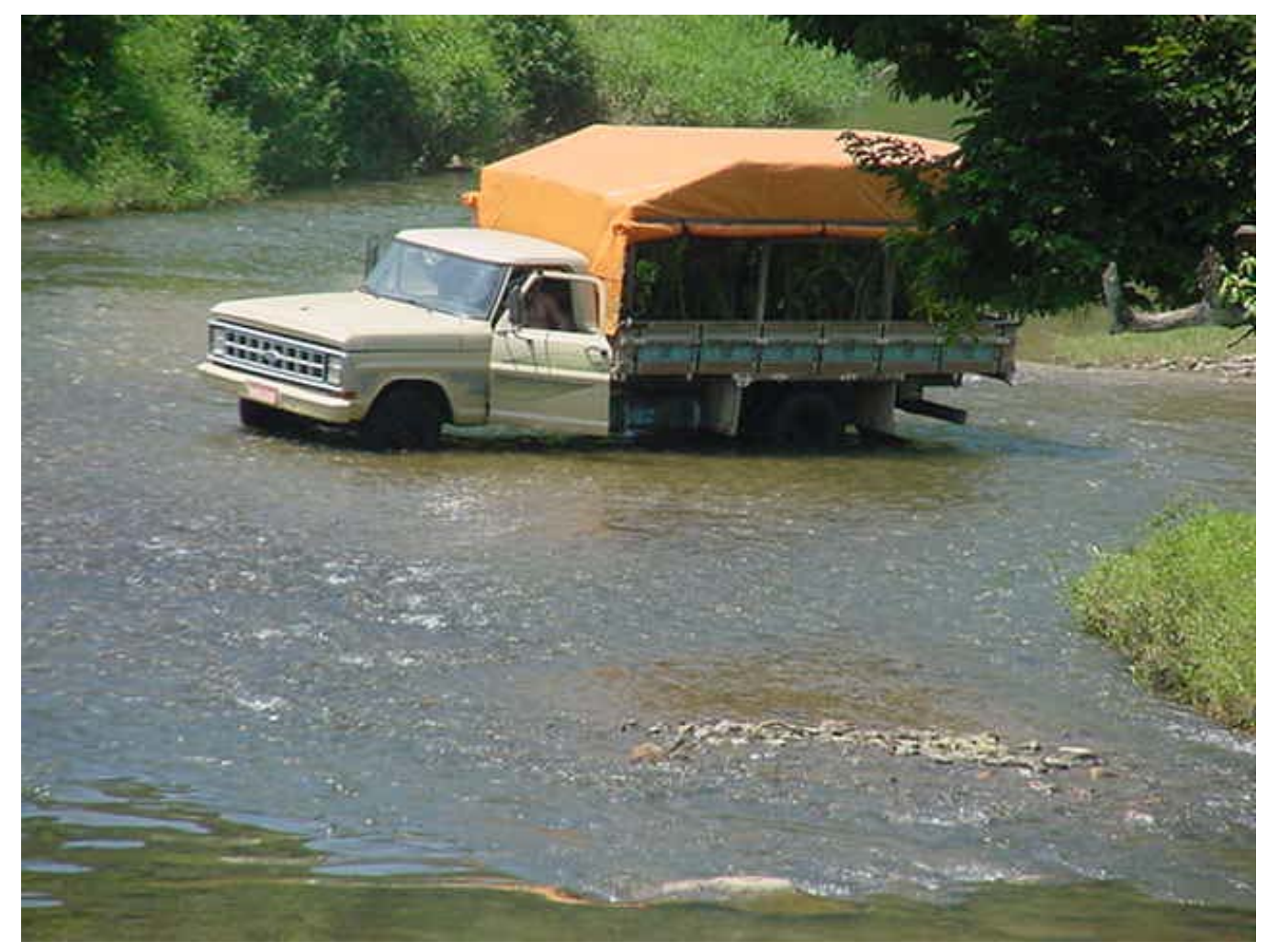

Foto-7: Caminhão de mudas a jusante, próximo, da captação de Iporanga 


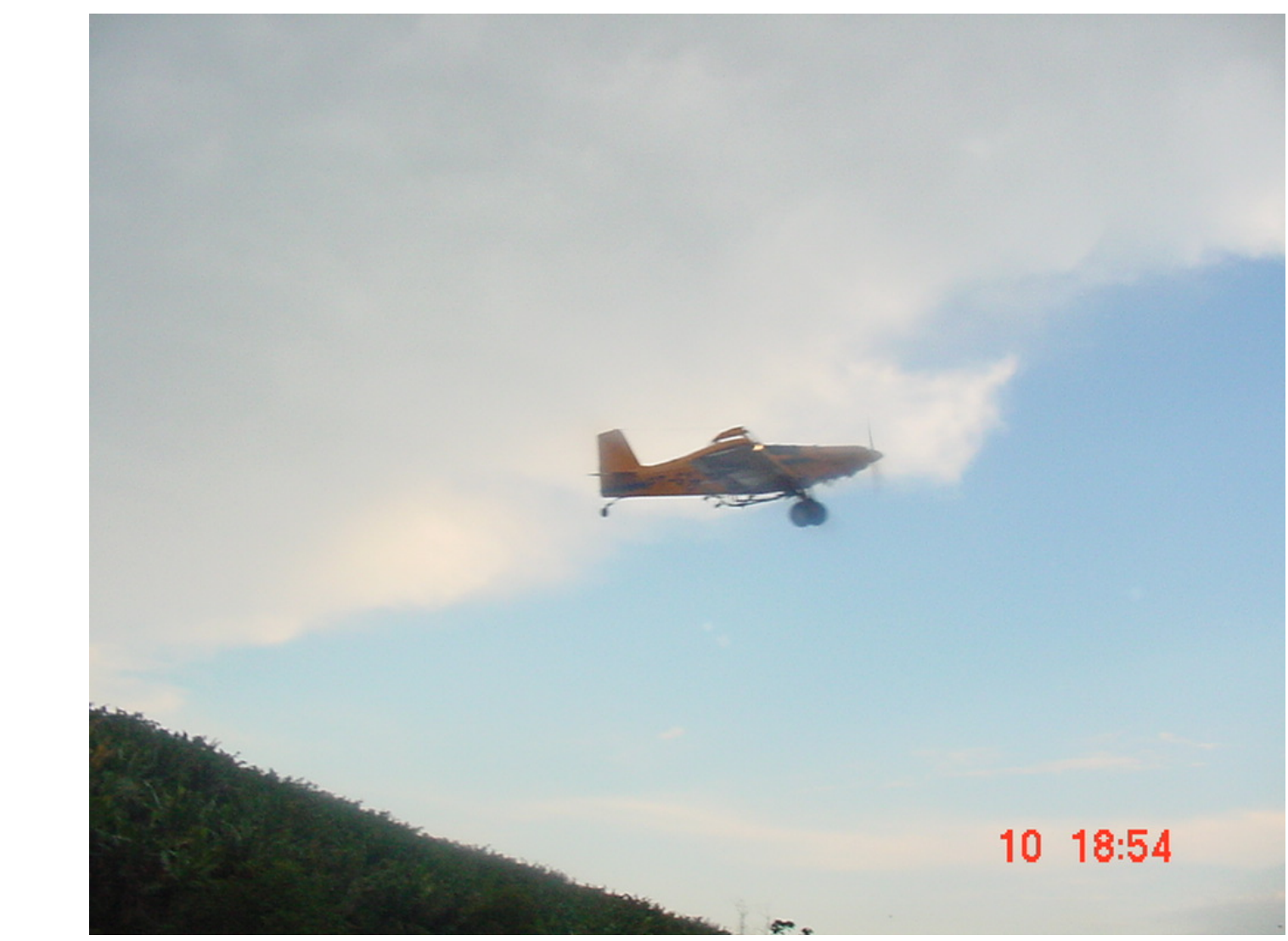

Foto - 8: Avião pulverizando agrotóxico em uma plantação de banana. Foto tirada na BR-116 próximo a cidade de Registro.
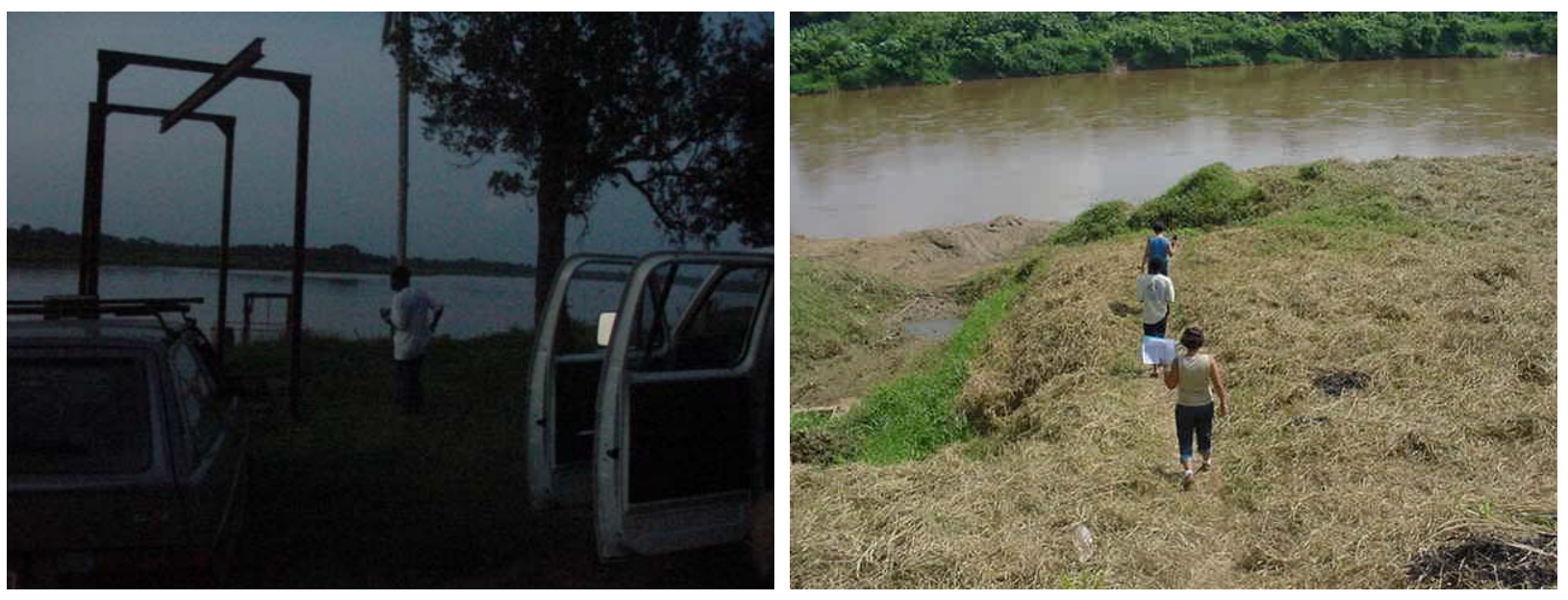

Foto - 9 Ponto de captação de Iguape

Foto - 10 Ponto de captação de Eldorado 


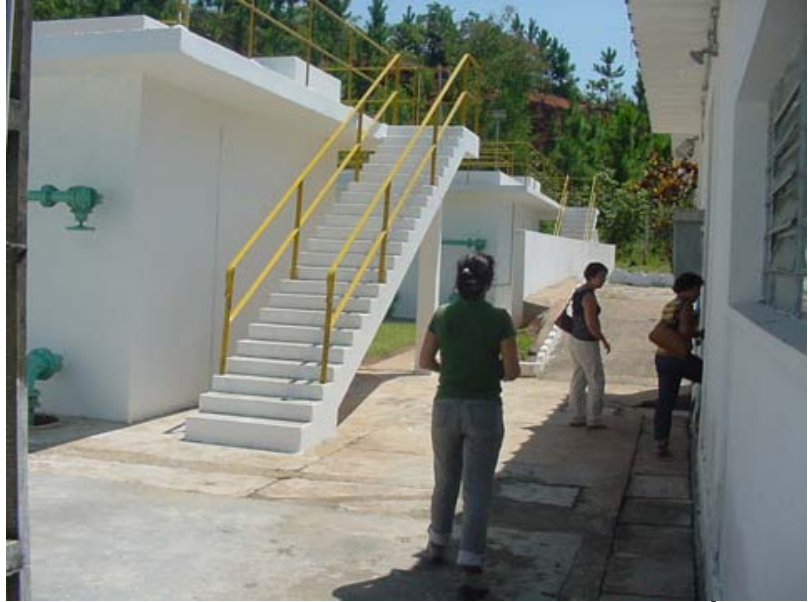

Foto - 11 Estação de Tratamento de Água (ETAs) de Sete Barras

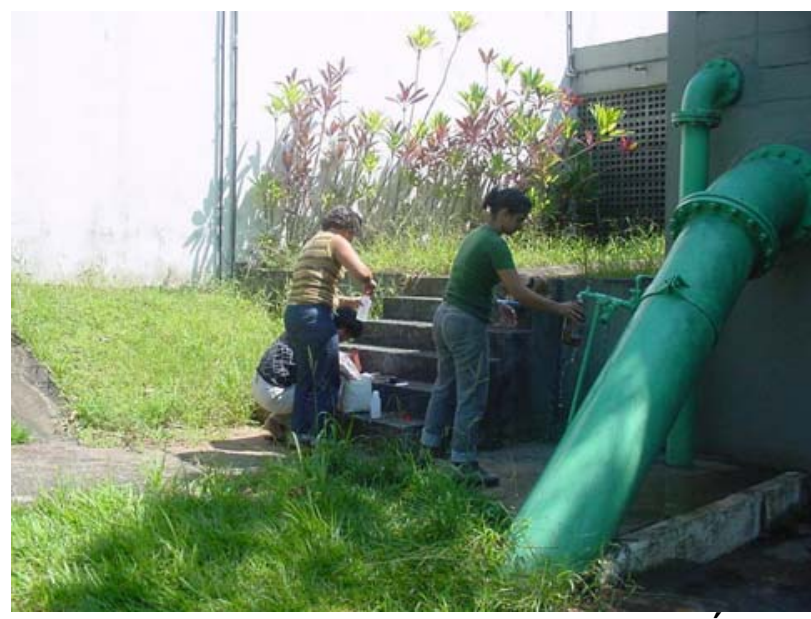

Foto - 13 Estação de Tratamento de Água (ETAs) de Registro

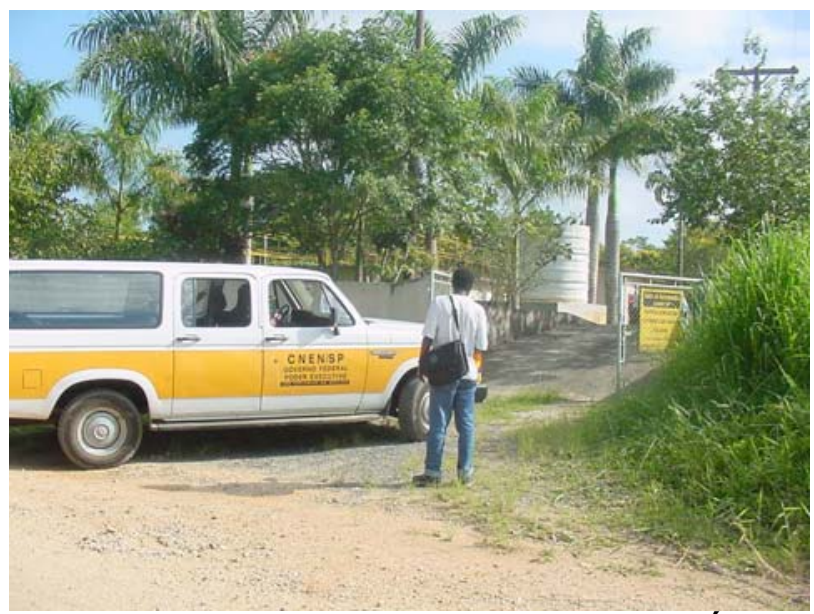

Foto - 15 Estação de Tratamento de Água (ETA) de Cananéia

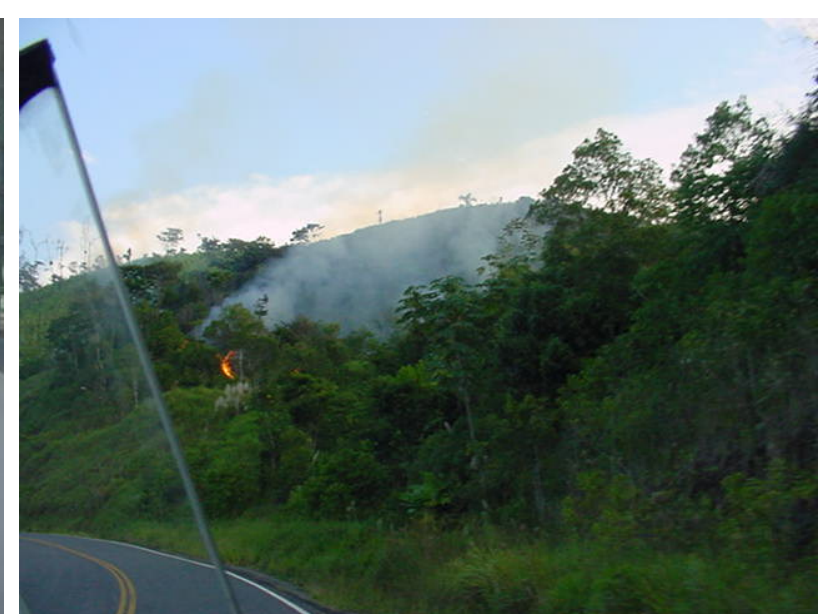

Foto - 12 Registro de queimada em APA

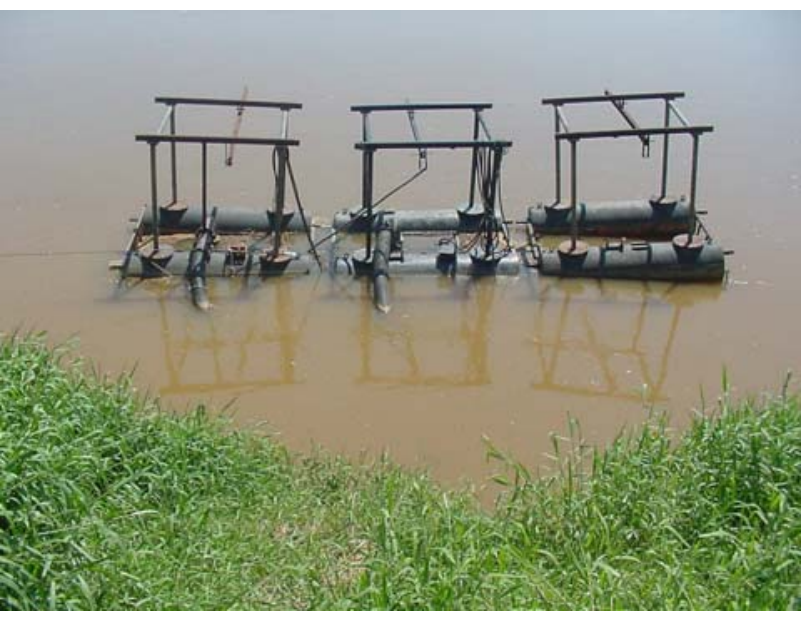

Foto - 14 Ponto de captação de Registro

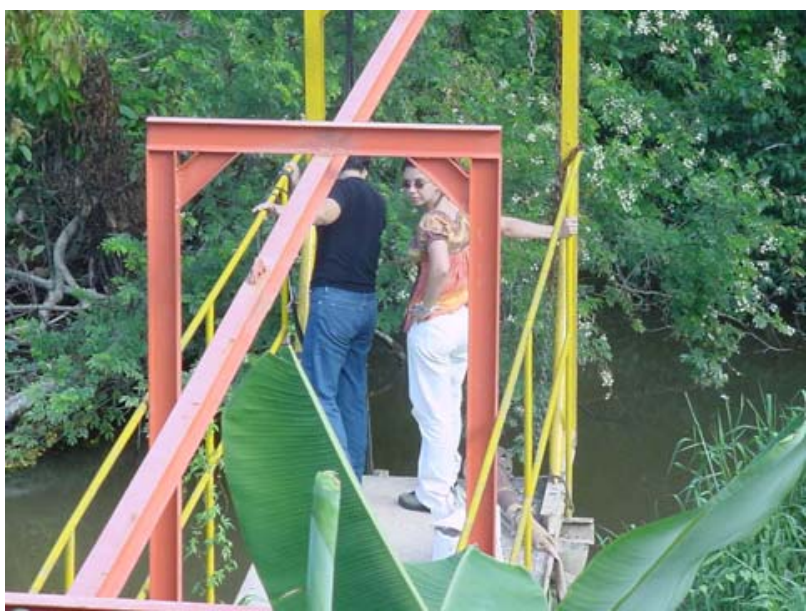

Foto - 16 Ponto de captação de Cananéia 


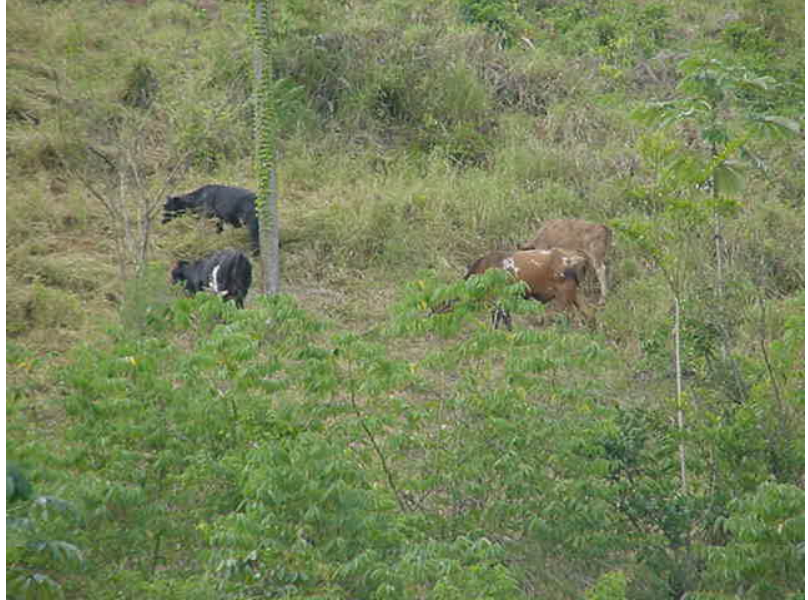

Foto - 17 Pasto em área de reserva entre Iporanga e Barra do turvo.

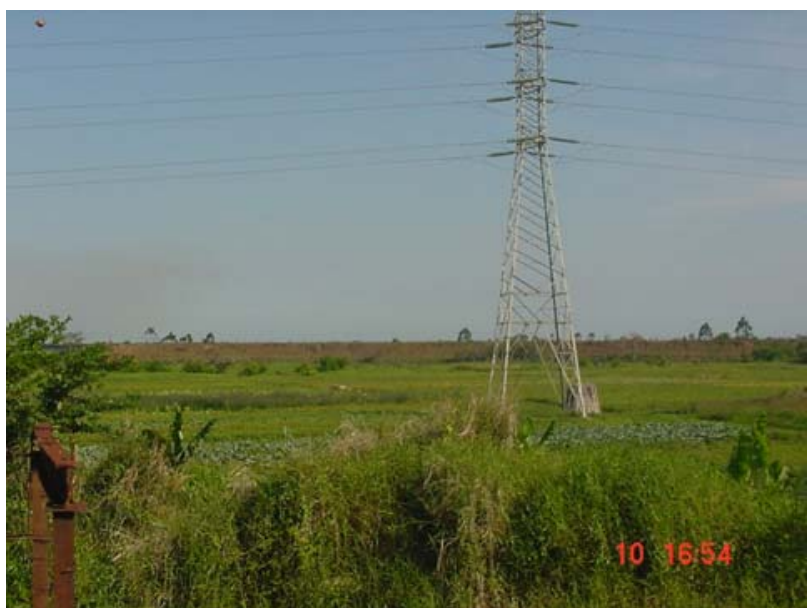

Foto - 19 Área com plantação de hortaliças ao redor do ponto de captação de Registro.

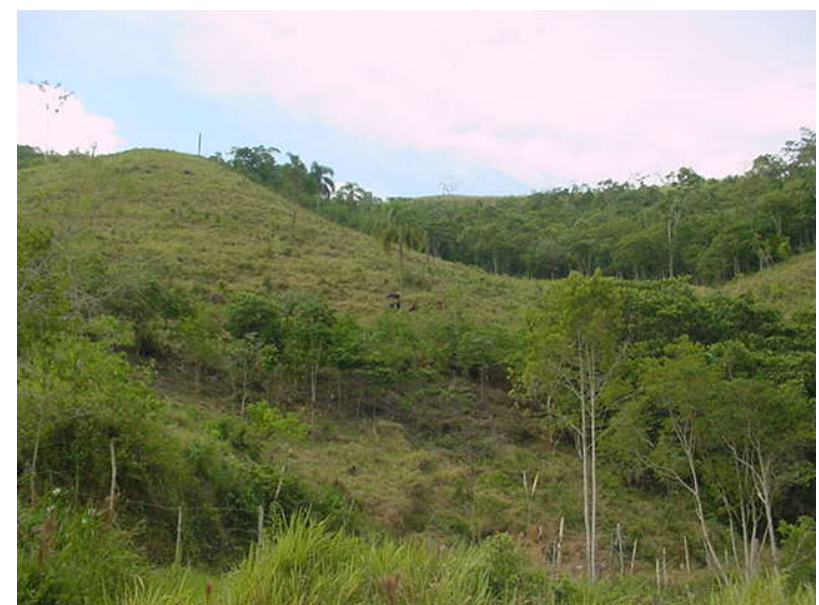

Foto - 18 Área de reserva entre Iporanga e Barra do turvo, morro completamente desmatado com plantação de braquiaria para pasto.

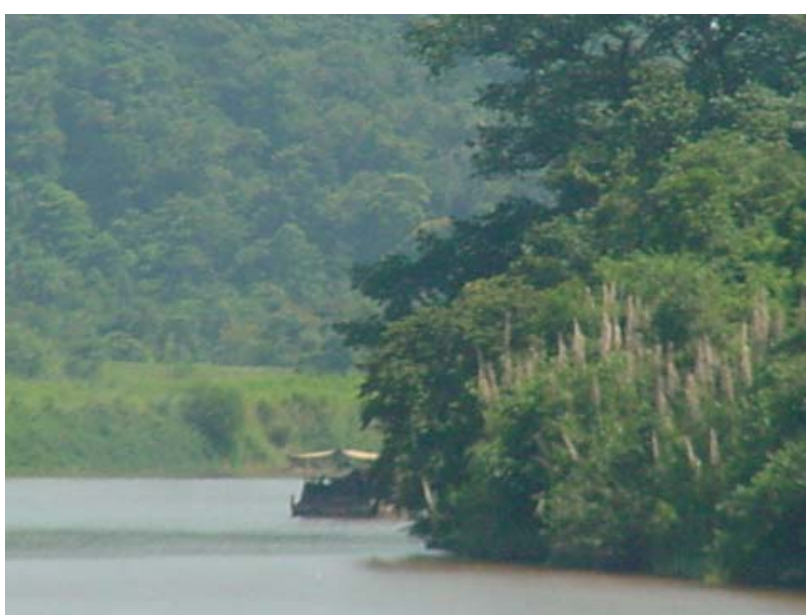

Foto - 20 Draga de mineração de areia entre Sete Barras e Registro, no rio Ribeira de Iguape. 
APÊNDICE D- Resultado das análises das amostras de água da Bacia Hidrográfica do Rio Ribeira de Iguape

TABELA D - Resultado das análises realizadas por SPE - LC - UV/visível

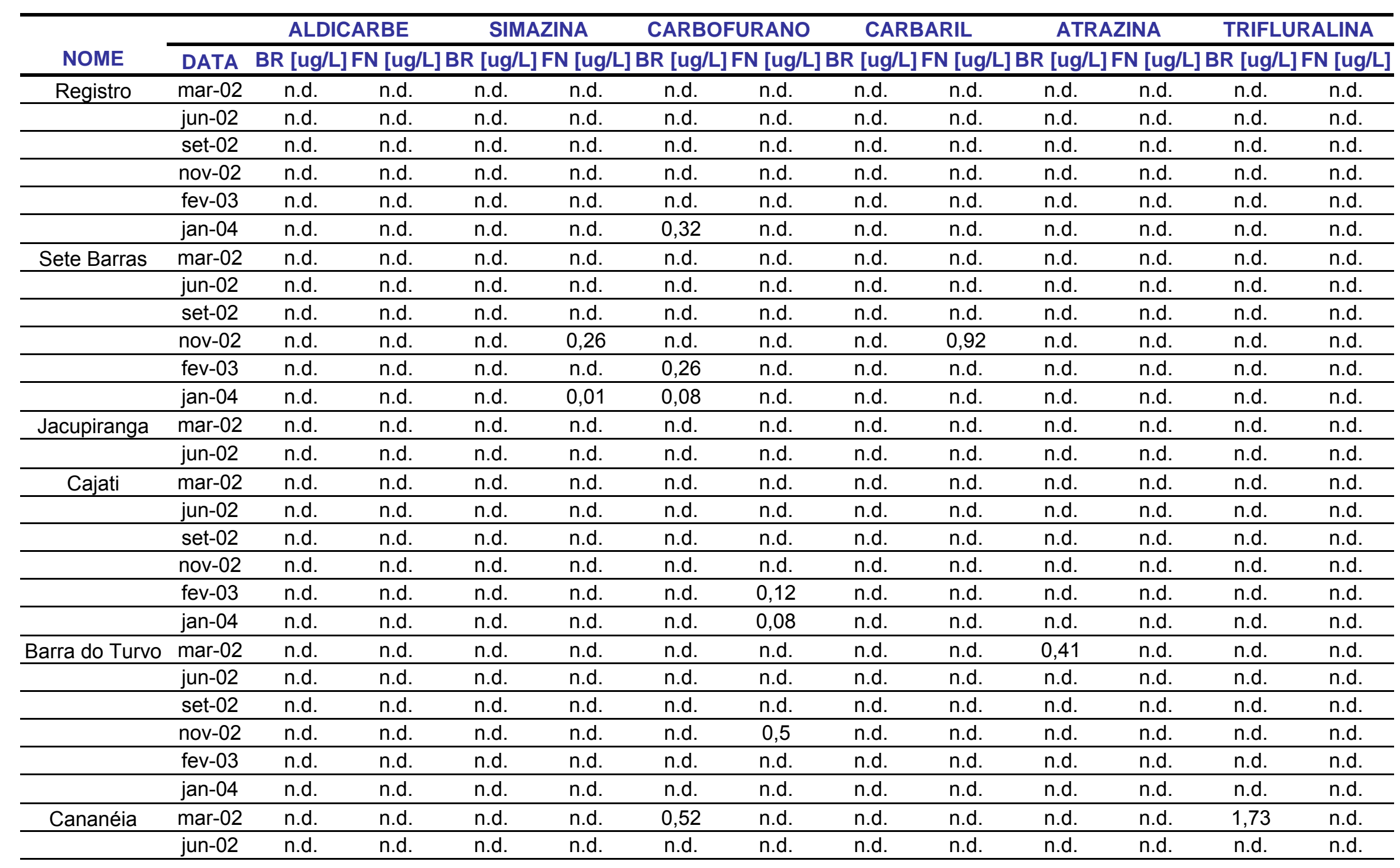


TABELA D - Resultado das análises realizadas por SPE - LC - UV/visível (continuação)

\begin{tabular}{|c|c|c|c|c|c|c|c|c|c|c|c|c|c|}
\hline \multirow[b]{2}{*}{ NOME } & \multicolumn{3}{|c|}{ ALDICARBE } & \multicolumn{2}{|c|}{ SIMAZINA } & \multicolumn{2}{|c|}{ CARBOFURANO } & \multicolumn{2}{|c|}{ CARBARIL } & \multicolumn{2}{|c|}{ ATRAZINA } & \multicolumn{2}{|c|}{ TRIFLURALINA } \\
\hline & DATA & BR [ug/l & N [ugl & [ug & N [ug & BR [ug & J [ug/L & R [ugl & ] [ug & BR [ug & $\sqrt{ }[\mathrm{ug} /$ & BR [ug & [ug/L] \\
\hline \multirow[t]{4}{*}{ Cananéia } & set-02 & n.d. & n.d. & n.d. & n.d. & n.d. & n.d. & n.d. & n.d. & n.d. & n.d. & n.d. & n.d. \\
\hline & nov-02 & n.d. & n.d. & n.d. & n.d. & n.d. & n.d. & n.d. & n.d. & n.d. & n.d. & n.d. & n.d. \\
\hline & fev-03 & n.d. & n.d. & n.d. & n.d. & n.d. & 1,62 & n.d. & n.d. & n.d. & n.d. & n.d. & n.d. \\
\hline & jan-04 & n.d. & n.d. & n.d. & n.d. & 0,1 & n.d. & n.d. & n.d. & n.d. & n.d. & n.d. & n.d. \\
\hline \multirow[t]{6}{*}{ Eldorado } & mar-02 & n.d. & n.d. & n.d. & n.d. & n.d. & n.d. & n.d. & n.d. & n.d. & n.d. & n.d. & n.d. \\
\hline & jun-02 & n.d. & n.d. & n.d. & n.d. & n.d. & n.d. & n.d. & n.d. & n.d. & n.d. & n.d. & n.d. \\
\hline & set-02 & n.d. & n.d. & n.d. & n.d. & 0,12 & n.d. & n.d. & n.d. & n.d. & n.d. & n.d. & n.d. \\
\hline & nov-02 & n.d. & n.d. & n.d. & n.d. & n.d. & n.d. & n.d. & n.d. & n.d. & n.d. & n.d. & n.d. \\
\hline & fev-03 & n.d. & n.d. & n.d. & n.d. & 0,60 & n.d. & n.d. & n.d. & n.d. & n.d. & n.d. & n.d. \\
\hline & jan-04 & n.d. & n.d. & n.d. & n.d. & 0,11 & n.d. & n.d. & n.d. & n.d. & n.d. & n.d. & n.d. \\
\hline \multirow[t]{2}{*}{ Pariquera Açu } & mar-02 & n.d. & n.d. & n.d. & n.d. & n.d. & n.d. & n.d. & n.d. & n.d. & n.d. & n.d. & n.d. \\
\hline & jun-02 & n.d. & n.d. & n.d. & n.d. & 0,15 & n.d. & n.d. & n.d. & n.d. & n.d. & 0,97 & n.d. \\
\hline \multirow[t]{6}{*}{ Juquiá } & mar-02 & 2,15 & n.d. & n.d. & n.d. & n.d. & n.d. & n.d. & n.d. & n.d. & n.d. & n.d. & n.d. \\
\hline & jun-02 & n.d. & n.d. & n.d. & n.d. & n.d. & n.d. & n.d. & n.d. & n.d. & n.d. & n.d. & n.d. \\
\hline & set-02 & n.d. & n.d. & n.d. & n.d. & n.d. & n.d. & n.d. & n.d. & n.d. & n.d. & n.d. & n.d. \\
\hline & nov-02 & n.d. & n.d. & n.d. & n.d. & n.d. & n.d. & n.d. & n.d. & n.d. & n.d. & n.d. & n.d. \\
\hline & fev-03 & n.d. & n.d. & n.d. & n.d. & n.d. & n.d. & n.d. & n.d. & n.d. & n.d. & n.d. & n.d. \\
\hline & jan-04 & n.d. & n.d. & n.d. & n.d. & n.d. & n.d. & n.d. & n.d. & n.d. & n.d. & n.d. & n.d. \\
\hline \multirow[t]{2}{*}{ Miracatu } & mar-02 & n.d. & n.d. & n.d. & n.d. & n.d. & n.d. & n.d. & n.d. & n.d. & n.d. & n.d. & n.d. \\
\hline & jun-02 & n.d. & n.d. & n.d. & n.d. & n.d. & n.d. & n.d. & n.d. & n.d. & n.d. & n.d. & n.d. \\
\hline \multirow[t]{6}{*}{ Iguape } & mar-02 & n.d. & n.d. & n.d. & n.d. & n.d. & n.d. & n.d. & n.d. & n.d. & n.d. & n.d. & n.d. \\
\hline & jun-02 & n.d. & n.d. & n.d. & n.d. & n.d. & n.d. & n.d. & n.d. & n.d. & n.d. & n.d. & n.d. \\
\hline & set-02 & n.d. & n.d. & n.d. & 0,01 & n.d. & n.d. & n.d. & n.d. & n.d. & n.d. & n.d. & n.d. \\
\hline & nov-02 & n.d. & n.d. & n.d. & n.d. & n.d. & n.d. & n.d. & n.d. & n.d. & 0,03 & n.d. & n.d. \\
\hline & fev-03 & n.d. & n.d. & n.d. & n.d. & 0,09 & 0,46 & n.d. & n.d. & n.d. & n.d. & 0,15 & n.d. \\
\hline & jan-04 & n.d. & n.d. & n.d. & n.d. & 0,11 & n.d. & n.d. & n.d. & n.d. & 0,04 & n.d. & n.d. \\
\hline \multirow[t]{2}{*}{ Itariri } & mar-02 & n.d. & n.d. & n.d. & n.d. & n.d. & n.d. & n.d. & n.d. & n.d. & n.d. & n.d. & n.d. \\
\hline & jun-02 & n.d. & n.d. & n.d. & n.d. & n.d. & n.d. & n.d. & n.d. & n.d. & n.d. & n.d. & n.d. \\
\hline
\end{tabular}


TABELA D - Resultado das análises realizadas por SPE - LC - UV/visível (continuação)

\begin{tabular}{|c|c|c|c|c|c|c|c|c|c|c|c|c|c|}
\hline \multirow[b]{2}{*}{ NOME } & \multicolumn{3}{|c|}{ ALDICARBE } & \multicolumn{2}{|c|}{ SIMAZINA } & \multicolumn{2}{|c|}{ CARBOFURANO } & \multicolumn{2}{|c|}{ CARBARIL } & \multicolumn{2}{|c|}{ ATRAZINA } & \multicolumn{2}{|c|}{ TRIFLURALINA } \\
\hline & DATA & BR [ug & $\mathrm{v}[\mathrm{ug} / \mathrm{l}$ & $\mathrm{R}[\mathrm{ug} / \mathrm{L}$ & $\mathrm{N}[\mathrm{ug} /$ & BR [ugl & N [ug/L & $\mathrm{R}[\mathrm{ug} /$ & $\sqrt{\mathrm{N}[\mathrm{ug} /}$ & $\mathrm{R}[\mathrm{ug} /$ & [ugl & R [ugl & $\mathrm{V}$ [ug/L] \\
\hline \multirow[t]{2}{*}{$\begin{array}{c}\text { Pedro de } \\
\text { Toledo }\end{array}$} & mar-02 & n.d. & n.d. & n.d. & n.d. & n.d. & n.d. & n.d. & n.d. & n.d. & n.d. & n.d. & n.d. \\
\hline & jun-02 & n.d. & n.d. & n.d. & n.d. & n.d. & n.d. & n.d. & n.d. & n.d. & n.d. & n.d. & n.d. \\
\hline \multirow[t]{6}{*}{ Juquitiba } & mar-02 & n.d. & n.d. & n.d. & n.d. & n.d. & n.d. & n.d. & n.d. & n.d. & n.d. & 0,59 & 2,06 \\
\hline & jun-02 & n.d. & n.d. & 0,03 & 0,03 & n.d. & n.d. & n.d. & n.d. & n.d. & n.d. & n.d. & n.d. \\
\hline & set-02 & n.d. & n.d. & n.d. & n.d. & n.d. & n.d. & n.d. & n.d. & n.d. & n.d. & n.d. & n.d. \\
\hline & nov-02 & n.d. & n.d. & n.d. & n.d. & n.d. & n.d. & n.d. & n.d. & n.d. & n.d. & n.d. & n.d. \\
\hline & fev-03 & n.d. & n.d. & n.d. & n.d. & 0,63 & 0,65 & n.d. & n.d. & n.d. & n.d. & n.d. & n.d. \\
\hline & jan-04 & n.d. & n.d. & n.d. & n.d. & n.d. & n.d. & n.d. & n.d. & 0,06 & n.d. & n.d. & n.d. \\
\hline \multirow[t]{2}{*}{$\begin{array}{c}\text { São Lourenço } \\
\text { da Serra } \\
\end{array}$} & mar-02 & n.d. & n.d. & n.d. & n.d. & n.d. & n.d. & n.d. & n.d. & n.d. & n.d. & n.d. & n.d. \\
\hline & jun-02 & n.d. & n.d. & n.d. & n.d. & n.d. & n.d. & n.d. & n.d. & n.d. & n.d. & n.d. & n.d. \\
\hline \multirow[t]{2}{*}{ Paiol do Meio } & mar-02 & n.d. & n.d. & n.d. & n.d. & n.d. & n.d. & n.d. & n.d. & n.d. & n.d. & n.d. & n.d. \\
\hline & jun-02 & n.d. & n.d. & n.d. & n.d. & n.d. & n.d. & n.d. & n.d. & n.d. & n.d. & n.d. & n.d. \\
\hline \multirow[t]{6}{*}{ Iporanga } & mar-02 & n.d. & n.d. & n.d. & n.d. & n.d. & n.d. & n.d. & n.d. & n.d. & n.d. & n.d. & n.d. \\
\hline & jun-02 & n.d. & $\mathrm{nf}$ & n.d. & $\mathrm{nf}$ & 0,16 & $\mathrm{nf}$ & n.d. & $\mathrm{nf}$ & n.d. & $\mathrm{nf}$ & n.d. & $\mathrm{nf}$ \\
\hline & set-02 & n.d. & n.d. & n.d. & n.d. & n.d. & n.d. & n.d. & n.d. & n.d. & n.d. & n.d. & n.d. \\
\hline & nov-02 & n.d. & n.d. & n.d. & n.d. & 0,5 & n.d. & n.d. & n.d. & n.d. & n.d. & n.d. & n.d. \\
\hline & fev-03 & n.d. & n.d. & n.d. & n.d. & 0,20 & 0,15 & n.d. & n.d. & n.d. & n.d. & n.d. & n.d. \\
\hline & jan-04 & n.d. & n.d. & n.d. & n.d. & n.d. & 0,13 & n.d. & n.d. & n.d. & n.d. & n.d. & n.d. \\
\hline \multirow[t]{2}{*}{ Tapirai } & mar-02 & n.d. & n.d. & n.d. & n.d. & n.d. & n.d. & n.d. & n.d. & n.d. & n.d. & n.d. & n.d. \\
\hline & jun-02 & n.d. & n.d. & n.d. & n.d. & n.d. & n.d. & n.d. & n.d. & n.d. & n.d. & n.d. & n.d. \\
\hline
\end{tabular}

Obs: n.d. = não detectado 
APÊNDICE E - Relação dos doze novos agrotóxicos inclusos no controle do padrão de potabilidade.

\section{TABELA E - Relação dos doze novos agrotóxicos inclusos no controle do padrão de potabilidade}

\begin{tabular}{|c|c|c|c|c|c|c|}
\hline Agrotóxico & PROPRIEDADES FísICO QUímICAS & $\begin{array}{c}\text { DL } 50 \text { Pl RATOS } \\
\left(\mathrm{mgkg}^{-1}\right)\end{array}$ & APLICAÇÃO & TIPO & $\begin{array}{l}\text { GRUPO } \\
\text { QUÍMICO }\end{array}$ & $\begin{array}{l}\text { GRUPO } \\
\text { CARCIN*. }\end{array}$ \\
\hline $\begin{array}{l}\text { Alaclor - 2-cloro-2',6'- } \\
\text { dietil-N-(metoximetil)- } \\
\text { acetanilida. }\end{array}$ & $\begin{array}{l}\text { PM.: } 269,8 \\
\text { F.M.: } \mathrm{C}_{14} \mathrm{H}_{20} \mathrm{ClNO}_{2} \\
\text { P.F.: } 39,4-41,5^{\circ} \mathrm{C} \\
\text { P.E.: } 100^{\circ} \mathrm{C} / 0,02 \mathrm{mmHg} \\
135^{\circ} \mathrm{C} / \mathrm{o}, 3 \mathrm{mmHg} \\
\text { P.V.: } 2,9 \mathrm{mPa}\left(25^{\circ} \mathrm{C}\right) \\
\text { Dens.: } 1,133\left(25^{\circ} \mathrm{C}\right) \\
\text { Forma: sólido levemente amarelado } \\
\text { Solubilidade: em água } \\
242 \mathrm{mg} / \mathrm{L}\left(25^{\circ} \mathrm{C}\right) . \text { Solúvel em éter } \\
\text { dietílico, acetona, benzeno, } \\
\text { clorofórmio, etanol e acetato de etila. } \\
\text { Estabilidade: é hidrolisado por ácidos } \\
\text { fortes e alcalis. É estável a luz uv e se } \\
\text { decompõe a } 105^{\circ} \mathrm{C}\end{array}$ & $930-1200$ & $\begin{array}{l}\text { Cultura de Soja e Algodão, } \\
\text { Milho, Cana-de-açúcar, } \\
\text { Girassol, Amendoim e Café } \\
\text { no combate a ervas } \\
\text { daninhas. }\end{array}$ & Herbicida & Acetamida & B2 \\
\hline $\begin{array}{l}\text { Atrazina - 2-cloro-4- } \\
\text { etilamino-6- } \\
\text { isopropilamino-S- } \\
\text { triazina. }\end{array}$ & $\begin{array}{l}\text { PM.: } 215,7 \\
\text { F.M.: } \mathrm{C}_{8} \mathrm{H}_{14} \mathrm{CIN}_{5} \\
\text { P.F.: } 175,8^{\circ} \mathrm{C} \\
\text { P.V.: } 0,039 \mathrm{mPa}\left(25^{\circ} \mathrm{C}\right) \\
\text { Dens.: } 1,187\left(20^{\circ} \mathrm{C}\right) \\
\mathrm{K}_{\text {ov: }} \operatorname{logP}=2,5\left(25^{\circ} \mathrm{C}\right) \\
\text { Forma: pó incolor } \\
\text { Solubilidade: em água } 33 \mathrm{mg} / \mathrm{L}\left(25^{\circ} \mathrm{C}\right) \text {. } \\
\text { Em metanol } 15, \text { acetato de etila } 24, \\
\text { acetona } 31, \text { diclorometano } 28, \text { tolueno } \\
6, \mathrm{n} \text {-hexano } 0,11, \text { n-octanol } 8,7 \text { (todos } \\
\left.\text { em g/L, } 25^{\circ} \mathrm{C}\right) \\
\text { Estabilidade: Relativamente estável } \\
\text { em meio neutro, fracamente ácido ou } \\
\text { alcalino. Rapidamente hidrolisado } \\
\text { para o derivado hidróxi em meio } \\
\text { fortemente ácido ou alcalino e em } \\
\text { meio neutro a temperatura de } 70^{\circ} \mathrm{C} \text {. } \\
\text { pKa: } 1,7\end{array}$ & 1869-3080 & $\begin{array}{l}\text { Cultura de Abacaxi, Soja, } \\
\text { Sisal, Sorgo, Seringueira, } \\
\text { Algodão, Milho, Cana-de- } \\
\text { açúcar no combate a ervas } \\
\text { daninhas. }\end{array}$ & Herbicida & Triazinas & C \\
\hline
\end{tabular}


TABELA E - Relação dos doze novos agrotóxicos inclusos no controle do padrão de potabilidade (continuação).

\begin{tabular}{|c|c|c|c|c|c|c|}
\hline Agrotóxico & $\begin{array}{c}\text { PROPRIEDADES FísICO } \\
\text { QUÍMICAS }\end{array}$ & $\begin{array}{c}\mathrm{DL}_{50} \mathrm{Pl} \\
\mathrm{RATOS} \\
\left(\mathrm{mgkg}^{-1}\right) \\
\end{array}$ & APLICAÇÃO & TIPO & GRUPO QUÍMICO & $\begin{array}{l}\text { GRUPO } \\
\text { CARCIN*. }\end{array}$ \\
\hline $\begin{array}{l}\text { Bentazone - 3- } \\
\text { isospropil-1H-benzo- } \\
\text { 2,1,3-tiadiazin-4-ona 2,2- } \\
\text { dióxido. }\end{array}$ & $\begin{array}{l}\text { PM.: } 240,3 \\
\text { F.M.: } \mathrm{C}_{10} \mathrm{H}_{12} \mathrm{~N}_{2} \mathrm{O}_{3} \mathrm{~S} \\
\text { P.F.: } 137-139^{\circ} \mathrm{C} \\
\text { P.V.: } 0,046 \mathrm{mPa}\left(20^{\circ} \mathrm{C}\right) \\
\text { Dens.: } 1,47\left(20^{\circ} \mathrm{C}\right) \\
\mathrm{K}_{\text {ow: }} 5,84(\mathrm{pH} 5), 0,35(\mathrm{pH} 7), 0,28(\mathrm{pH} 9) \\
\text { Forma: cristal incolor } \\
\text { Solubilidade: em água } 570 \mathrm{mg} / \mathrm{L}\left(20^{\circ} \mathrm{C}\right) . \\
\text { Em .acetato de etila } 650, \text { acetona } 1507 \text {, } \\
\text { etanol } 861 \text {,éter dietílico } 616, \text { clorofórmio } \\
180, \text { benzeno } 33, \text { ciclohexano } 0,2 \text { (todos } \\
\left.\text { em g/L, } 20^{\circ} \mathrm{C}\right) \\
\text { Estabilidade: Resistente a hidrólise tanto } \\
\text { em meio ácido como alcalino.Se } \\
\text { decompõe na luz uv. } \\
\text { PKa: } 3,3\left(24^{\circ} \mathrm{C}\right)\end{array}$ & $>1000$ & $\begin{array}{l}\text { Culturas de Amendoim, } \\
\text { Arroz, Feijão, Milho, Soja } \\
\text { e Trigo no combate a } \\
\text { ervas daninhas. }\end{array}$ & Herbicida & Benzotiadiazina & $E$ \\
\hline $\begin{array}{l}\text { Endossulfan - } \\
6,7,8,9,10,10 \text {-hexacloro- } \\
1,5,5^{\mathrm{a}}, 6,9,9^{\mathrm{a}} \text {-hexaidro- } \\
6,9 \text {-metano-2,4,3- } \\
\text { benzodioxatiepin-3-óxido }\end{array}$ & $\begin{array}{l}\text { PM.: } 406,9 \\
\text { F.M.: } \mathrm{C}_{9} \mathrm{H}_{6} \mathrm{Cl}_{6} \mathrm{O}_{3} \mathrm{~S} \\
\text { P.F.: } \geq 80^{\circ} \mathrm{C}\left(\text { téc.), } \alpha 109,2^{\circ} \mathrm{C} \text { e } \beta 213,3^{\circ} \mathrm{C}\right. \\
\text { P.V.: } 0,83 \mathrm{mPa}\left(20^{\circ} \mathrm{C}\right) \text { para mistura } 2: 1 \\
\text { dos ulfúric } \alpha \text { e } \beta \text {, repectivamente } \\
\text { Dens.: } 1,8\left(20^{\circ} \mathrm{C}\right) \text { ( téc.) } \\
\mathrm{K}_{\text {ow: }} \text { logP } \alpha=4,74 ; \beta=4,79 \text { (ambos em } \\
\text { pH 5) } \\
\text { Forma: cristal incolor (téc. Levemente } \\
\text { marrom ou bege) } \\
\text { Solubilidade: em água alfa-endossulfan } \\
0,32 \text { e beta -endossulfan } 0,33(\text { ambos em } \\
\text { mg/L } 22^{\circ} \mathrm{C} \text { ). Em .acetato de etila } \\
\text {,diclorometano, tolueno } 200 \text {, etanol c. } 65 \text {, } \\
\text { hexanoc.24 (todos em g/L, } 20^{\circ} \mathrm{C} \text { ) } \\
\text { Estabilidade: ulfúri a luz solar. } \\
\text { Lentamente hidrolisado em solução } \\
\text { aquosa ácida ou alcalina, com a } \\
\text { formação de diol e dióxido ulfúrico. }\end{array}$ & $\begin{array}{c}70 \text { (sol. } \\
\text { Aquosa), } 110 \\
\text { (em óleo), } 76 \\
\alpha \text {-isomero e } \\
240 \mathrm{~g} \beta- \\
\text { isomero }\end{array}$ & $\begin{array}{l}\text { Culturas de Algodão, } \\
\text { Café, Cacau e Soja no } \\
\text { combate a pragas como } \\
\text { pulgões, ácaros, } \\
\text { lagartas,curuquerê, } \\
\text { tripés, besourinhos, } \\
\text { percevejos, vaquinhas e } \\
\text { brocas. }\end{array}$ & $\begin{array}{l}\text { Acaricida e } \\
\text { inseticida }\end{array}$ & $\begin{array}{c}\text { Éster sulfuroso } \\
\text { de um diol } \\
\text { cíclico. }\end{array}$ & \\
\hline
\end{tabular}


TABELA E - Relação dos doze novos agrotóxicos inclusos no controle do padrão de potabilidade (continuação).

\begin{tabular}{|c|c|c|c|c|c|c|}
\hline Agrotóxico & $\begin{array}{c}\text { PROPRIEDADES FísICO } \\
\text { QUÍMICAS }\end{array}$ & $\begin{array}{l}\mathrm{DL}_{50} \mathrm{Pl} \\
\mathrm{RATOS}^{-1} \\
\left(\mathrm{mgkg}^{-1}\right)\end{array}$ & APLICAÇÃO & TIPO & GRUPO QUÍMICO & $\begin{array}{l}\text { GRUPO } \\
\text { CARCIN*. }\end{array}$ \\
\hline $\begin{array}{l}\text { Glifosato - sal de } \\
\text { isopropilamina de } \mathrm{N} \\
\text { (Fosfonometil)-glicina }\end{array}$ & $\begin{array}{l}\text { PM.: } 169,1 \\
\text { F.M.: } \mathrm{C}_{3} \mathrm{H}_{8} \mathrm{NO}_{5} \mathrm{P} \\
\text { P.F.: } 200^{\circ} \mathrm{C} \\
\text { P.V.: } 1,84.10^{-7} \mathrm{mmHg} \text { a } 45^{\circ} \mathrm{C}(\text { ácido) } \\
\text { Dens.: } 0,5 \mathrm{~g} / \mathrm{cm}^{3} \text { (da mistura dos } \\
\text { derivados); } 1,74 \mathrm{~g} / \mathrm{cm}^{3} \text { (ácido) } \\
\mathrm{K}_{\text {ow: }} 0,0006-0,0017 \\
\text { pka } 2,6 \text { a } 10,3 \\
\text { Forma: cristal incolor } \\
\text { Solubilidade: em água } 12 \mathrm{~g} / \mathrm{L}\left(25^{\circ} \mathrm{C}\right) \text {. } \\
\text { Insolúvel em solventes orgânicos } \\
\text { comuns, como pro exemplo: acetona, } \\
\text { etanol e xileno.Os sais de metais } \\
\text { alcalinos e amônio são solúveis em } \\
\text { água. } \\
\text { Estabilidade: Estavel até } 60^{\circ} \mathrm{C} \text { e a luz. }\end{array}$ & $>5600$ & $\begin{array}{l}\text { Culturas de Arroz, Ameixa, } \\
\text { Banana, Cacau, Café, Cana- } \\
\text { de-açúcar, Cítrus, Maçã, } \\
\text { Nectarina, Soja, Uva, } \\
\text { Pastagens, Pêra, Pêssego, } \\
\text { Soja, Milho, Trigo, Uva no } \\
\text { combate de ervas daninhas. } \\
\text { Áreas de reflorestamento: } \\
\text { eucaliptos e pinos e áreas } \\
\text { urbanas: estradas de ferro, } \\
\text { calçadas, jardins, ruas etc. }\end{array}$ & Herbicida & $\begin{array}{l}\text { Derivado da } \\
\text { glicina }\end{array}$ & $D$ \\
\hline $\begin{array}{l}\text { Metolacloro - 2-etil-6- } \\
\text { metil-N-(1-metil-2- } \\
\text { metoxietil) } \\
\text { cloroacetanilida. }\end{array}$ & $\begin{array}{l}\text { PM.: } 283,8 \\
\text { F.M.: } \mathrm{C}_{15} \mathrm{H}_{22} \mathrm{CINO}_{2} \\
\text { P.F.: } 100^{\circ} \mathrm{C} / 0,001 \mathrm{mmHg} \\
\text { P.V.: } 4,2 \mathrm{mPa}\left(25^{\circ} \mathrm{C}\right) \\
\text { Dens.: } 1,12\left(20^{\circ} \mathrm{C}\right) \\
\mathrm{K}_{\text {ow: }} \text { log } \mathrm{P}=2,9\left(25^{\circ} \mathrm{C}\right) \\
\text { Forma: líquido límpido } \\
\text { Solubilidade: em água } 488 \mathrm{mg} / \mathrm{L}\left(25^{\circ} \mathrm{C}\right) \text {. } \\
\text { Misível com benzeno, tolueno, xileno, } \\
\text { hexano, dimetilformamida, dicloreto de } \\
\text { etileno, ciclohexano, metanol, octanol e } \\
\text { diclorometano. Insolúvel em etileno } \\
\text { glicol, propileno glicol e éter de petróleo. } \\
\text { Estabilidade: Estavel até } 300^{\circ} \mathrm{C} \text {. Sfre } \\
\text { hidrólise por alcalis e ácidos minerais } \\
\text { fortes. } \\
\text { P. Fulgor: }>100^{\circ} \mathrm{C}\end{array}$ & 2780 & $\begin{array}{l}\text { Culturas de Soja, Milho, } \\
\text { Cana-de-açúcar, Feijão no } \\
\text { combate de ervas daninhas. }\end{array}$ & Herbicida & Cloroacetanilida & $\mathrm{C}$ \\
\hline
\end{tabular}


TABELA E - Relação dos doze novos agrotóxicos inclusos no controle do padrão de potabilidade (continuação).

\begin{tabular}{|c|c|c|c|c|c|c|}
\hline Agrotóxico & $\begin{array}{c}\text { PROPRIEDADES FíSICO } \\
\text { QUÍMICAS }\end{array}$ & $\begin{array}{c}\text { DL }_{50} \text { Pl RATOS } \\
\left(\mathrm{mgkg}^{-1}\right)\end{array}$ & APLICAÇÃO & TIPO & $\begin{array}{l}\text { GRUPO } \\
\text { QUÍMICO }\end{array}$ & $\begin{array}{l}\text { GRUPO } \\
\text { CARCIN*. }\end{array}$ \\
\hline $\begin{array}{l}\text { Molinato - S-etil- } \\
\text { hexaidro-1H-azepina-1- } \\
\text { carbotioato. }\end{array}$ & $\begin{array}{l}\text { PM.: } 187,3 \\
\text { F.M.: } \mathrm{C}_{9} \mathrm{H}_{17} \mathrm{NOS} \\
\text { P.F.: } 202^{\circ} \mathrm{C} / 10 \mathrm{mmHg} \\
\text { P.V.: } 746 \mathrm{mPa}\left(25^{\circ} \mathrm{C}\right) \\
\text { Dens.: } 1,063\left(25^{\circ} \mathrm{C}\right) \\
\mathrm{K}_{\text {ow: }} \text { logP }=2,88 \\
\text { Forma: Iíquido límpido } \\
\text { Solubilidade: em água } 88 \mathrm{mg} / \mathrm{L}\left(20^{\circ} \mathrm{C}\right) \text {. } \\
\text { Misível com muitos solventes orgânicos } \\
\text { comuns, como pro exemplo: acetona, } \\
\text { etanol, metanol, querosene, metil isobutil } \\
\text { cetona, benzeno e xileno. } \\
\text { Estabilidade: Estável até } 2 \text { anos a } \\
\text { temperatura ambiente e até } 1 \text { mês à } \\
120^{\circ} \mathrm{C} \text {. Relativamente estável a hidrólise } \\
\text { por ácido e alcalis (pH } 5-9) \text { até } 40^{\circ} \mathrm{C} . \\
\text { Instável á luz. } \\
\text { P. Fugor: }>100^{\circ} \mathrm{C}\end{array}$ & $\begin{array}{c}369 \text { para } \\
\text { macho e } 450 \\
\text { para fêmea }\end{array}$ & $\begin{array}{l}\text { Culturas de Arroz irrigado } \\
\text { no combate de ervas } \\
\text { daninhas. }\end{array}$ & Herbicida & Tiocarbamato & \\
\hline $\begin{array}{l}\text { Pendimetalina - N-(1- } \\
\text { etilpropil)-3,4-dimetil-2,6- } \\
\text { dinitrobenzenoamina. }\end{array}$ & $\begin{array}{l}\text { PM.: } 281,3 \\
\text { F.M.: } \mathrm{C}_{13} \mathrm{H}_{19} \mathrm{~N}_{3} \mathrm{O}_{4} \\
\text { P.F.: } 54-58^{\circ} \mathrm{C} \\
\text { P.E. decompõe-se na destilação } \\
\text { P.V.: } 4,0 \mathrm{mPa}\left(25^{\circ} \mathrm{C}\right) \\
\text { Dens.: } 1,19\left(25^{\circ} \mathrm{C}\right) \\
\mathrm{K}_{\text {ow: }} 152000 \\
\text { Forma: cristal amarelo-alaranjado } \\
\text { Solubilidade: em água } 0,3 \mathrm{mg} / \mathrm{L}\left(20^{\circ} \mathrm{C}\right) . \\
\text { Em acetona } 700, \text { xileno } 628 \text {, óleo de } \\
\text { milho } 148, \text { heptano } 138 \text {, isopropanol } 77 \\
\left.\text { (todos em g/L, } 26^{\circ} \mathrm{C}\right) \text {. Facilmente solúvel } \\
\text { em benzeno, tolueno, clorofórmio e } \\
\text { diclometano. Levemente solúvel em éter } \\
\text { de petróleo e gasolina. } \\
\text { Estabilidade: Muito estável em boas } \\
\text { condições de armazenagem, estocar em } \\
\text { temperatura entre } 5 \text { e } 130^{\circ} \mathrm{C} \text {. Estável em } \\
\text { ácidos e alcalis. Decompõe-se } \\
\text { lentamente na luz. } \mathrm{DT}_{50} \text { (meia-vida) em } \\
\text { água < } 21 \text { dias. }\end{array}$ & $\begin{array}{c}1250 \text { para } \\
\text { macho e } 1050 \\
\text { para fêmea }\end{array}$ & $\begin{array}{l}\text { Culturas de Arroz, Milho, } \\
\text { Trigo, Café, Algodão, } \\
\text { Feijão, Amendoim, } \\
\text { Tabaco, Batata, Algodão, } \\
\text { Soja, Alho, Cebola e } \\
\text { Cana-de-açúcar no } \\
\text { combate de ervas } \\
\text { daninhas. }\end{array}$ & Herbicida & Dinitroanilina & \\
\hline
\end{tabular}


TABELA E - Relação dos doze novos agrotóxicos inclusos no controle do padrão de potabilidade (continuação).

\begin{tabular}{|c|c|c|c|c|c|c|}
\hline Agrotóxico & PROPRIEDADES FÍSICO QUÍMICAS & $\begin{array}{c}\text { DL }_{50} \text { P/ RATOS } \\
\left(\mathrm{mgkg}^{-1}\right)\end{array}$ & APLICAÇÃO & TIPO & $\begin{array}{l}\text { GRUPO } \\
\text { QUÍMICO }\end{array}$ & $\begin{array}{l}\text { GRUPO } \\
\text { CARCIN*. }\end{array}$ \\
\hline $\begin{array}{l}\text { Permetrina - 3- } \\
\text { fenoxibenzil( } \pm \text { )cis, } \\
\text { trans3-(2,2-diclorovinil)- } \\
2,22,2 \text { dimetil } \\
\text { ciclopropano-1- } \\
\text { carboxilato. }\end{array}$ & $\begin{array}{l}\text { PM.: } 391,3 \\
\text { F.M.: } \mathrm{C}_{21} \mathrm{H}_{20} \mathrm{Cl}_{2} \mathrm{O}_{3} \\
\text { P.F.: } 34-35^{\circ} \mathrm{C} \text {; cis }-63-65^{\circ} \mathrm{C} \text {; trans - } \\
44-47^{\circ} \mathrm{C} \\
\mathrm{P} . \mathrm{E} .200^{\circ} \mathrm{C} / 0,1 \mathrm{mmHg} ;>290^{\circ} \mathrm{C} / 760 \mathrm{mmHg} \\
\text { P.V.: } 0,045 \mathrm{mPa}\left(25^{\circ} \mathrm{C}\right) ; \mathrm{cis}-0,0025 \mathrm{mPa} \text {; trans } \\
0,0015 \mathrm{mPa}\left(\mathrm{ambos} \text { à } 20^{\circ} \mathrm{C}\right) \\
\text { Dens.: } 1,19-1,27\left(20^{\circ} \mathrm{C}\right) \\
\mathrm{K}_{\text {ow: }} \text { logP }=6,1\left(20^{\circ} \mathrm{C}\right) \\
\text { Forma: grau técn. líquido castanho até marrom; } \\
\text { com tendência a se cristalizar parcialmente à } \\
\text { temperatura ambiente. } \\
\text { Solubilidade: em água } \cong 0,2 \mathrm{mg} / \mathrm{L}\left(20^{\circ} \mathrm{C}\right) . \text { Em } \\
\text { xileno e hexano > } 1000, \text { metanol } 258 \text { (todos em } \\
\left.\text { g/L, } 25^{\circ} \mathrm{C}\right) . \\
\text { Estabilidade: Estável ao calor }\left(2 \text { a } 50^{\circ} \mathrm{C}\right) \text {, mais } \\
\text { estável em meio ácido que alcalino, com ótima } \\
\text { eatabilidade em pH próximo de } 4 ; \text { algumas } \\
\text { degradações fotoquímicas foram observadas } \\
\text { nos estudos de laboratórios, mas dados de } \\
\text { campo indicam que isto não interfere no efeito } \\
\text { da ação bilógica. } \\
\text { P. Fugor: }>100^{\circ} \mathrm{C}\end{array}$ & $\begin{array}{c}\text { Os valores } \\
\text { para uma } \\
\text { razão } \\
\text { cis/trans } \cong \\
\text { 40:60 estão } \\
\text { entre: } 430- \\
4000\end{array}$ & $\begin{array}{l}\text { Culturas de algodão, } \\
\text { Soja, Café, Milho, } \\
\text { Tomate, Crucíferas } \\
\text { (couve, couve-flor e } \\
\text { repolho) Fumo, Trigo, } \\
\text { Arroz irrigado, grãos } \\
\text { armazenados no } \\
\text { combate as pragas } \\
\text { como: lagartas, } \\
\text { curuquerê, percevejos, } \\
\text { bicho mineiro, brocas, } \\
\text { gorgulho, tripés, traças e } \\
\text { pulgões. }\end{array}$ & Inseticida & $\begin{array}{l}\text { Piretróides } \\
\text { sintéticos }\end{array}$ & \\
\hline
\end{tabular}


TABELA E - Relação dos doze novos agrotóxicos inclusos no controle do padrão de potabilidade (continuação).

\begin{tabular}{|c|c|c|c|c|c|c|}
\hline Agrotóxico & PROPRIEDADES FÍSICO QUÍMICAS & $\begin{array}{c}\text { DL }_{50} \text { Pl RATOS } \\
\left(\mathrm{mgkg}^{-1}\right)\end{array}$ & APLICAÇÃO & TIPO & $\begin{array}{l}\text { GRUPO } \\
\text { QUÍMICO }\end{array}$ & $\begin{array}{l}\text { GRUPO } \\
\text { CARCIN*. }\end{array}$ \\
\hline $\begin{array}{l}\text { Propanil - 3,4- } \\
\text { dicloropropionanilida. }\end{array}$ & 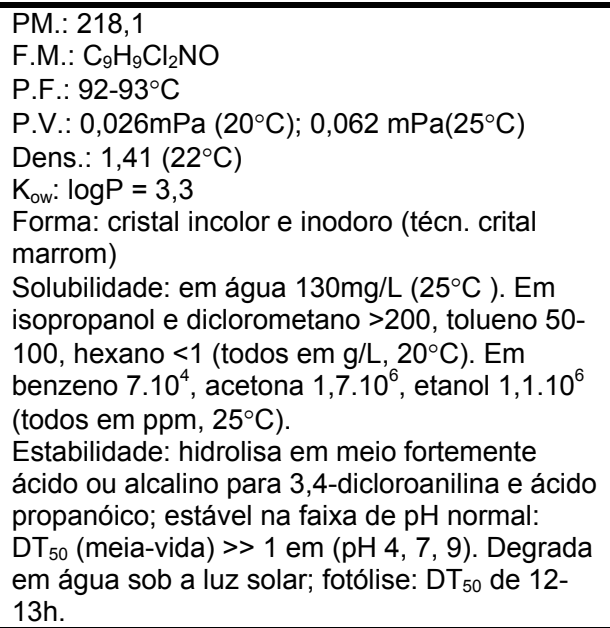 & $>2500$ & $\begin{array}{l}\text { Culturas de Arroz } \\
\text { irrigado no combate de } \\
\text { ervas daninhas }\end{array}$ & Herbicida & Cloroanilida & \\
\hline $\begin{array}{l}\text { Simazina - 2-cloro-4,6- } \\
\text { bis-(etilamino)-S-triazina. }\end{array}$ & 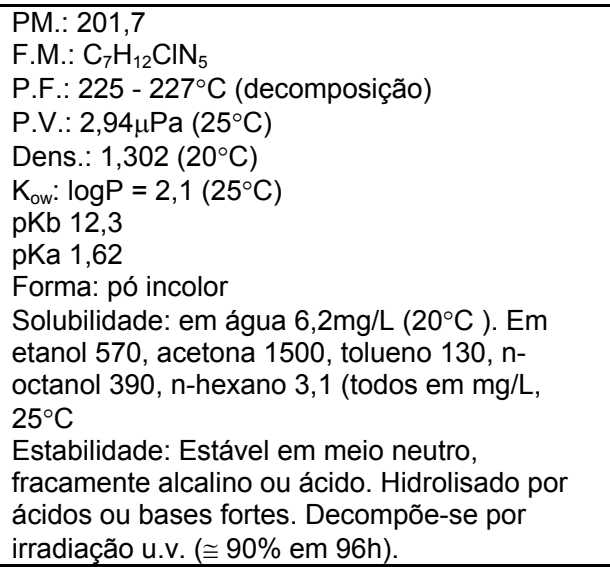 & $>5000$ & $\begin{array}{l}\text { Culturas de Milho, } \\
\text { Abacaxi, Cana-de- } \\
\text { açúcar, Coníferas, } \\
\text { Café, Sisal, Sorgo e } \\
\text { Seringueira no } \\
\text { combate de ervas } \\
\text { daninhas. }\end{array}$ & Herbicidas & Triazinas & $\mathrm{C}$ \\
\hline
\end{tabular}


TABELA E - Relação dos doze novos agrotóxicos inclusos no controle do padrão de potabilidade (continuação).

\begin{tabular}{|c|c|c|c|c|c|c|}
\hline Agrotóxico & $\begin{array}{c}\text { PROPRIEDADES FíSICO } \\
\text { QUÍMICAS }\end{array}$ & $\begin{array}{l}\text { DL }_{50} \text { P/ RATOS } \\
\left(\mathrm{mgkg}^{-1}\right)\end{array}$ & APLICAÇÃO & TIPO & $\begin{array}{l}\text { GRUPO } \\
\text { QUímICO }\end{array}$ & $\begin{array}{l}\text { GRUPO } \\
\text { CARCIN*. }\end{array}$ \\
\hline $\begin{array}{l}\text { Trifluralina - -a,a,a,- } \\
\text { trifluoro-2,6-dinitro-N,N- } \\
\text { dipropil-p-toluidina. }\end{array}$ & 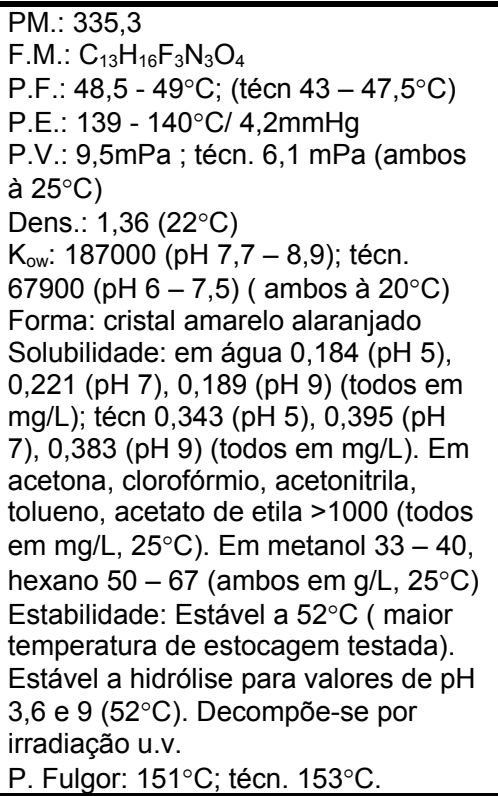 & $>5000$ & $\begin{array}{l}\text { Culturas de Algodão, } \\
\text { Alho, Amendoim, Arroz, } \\
\text { Berinjelas, Brássicas } \\
\text { (couve, couve-flor, } \\
\text { brócolos,repolho), Café, } \\
\text { Cebola de transplante, } \\
\text { Tomate de transplante, } \\
\text { Cenoura, Cítrus, Feijão, } \\
\text { Feijão-vagem, Girassol, } \\
\text { Mandioca,Mamona, Milho, } \\
\text { Pimentão, Quiabo, Soja, } \\
\text { Fumo e Plantas } \\
\text { ornamentais no combate } \\
\text { de ervas daninhas. }\end{array}$ & Herbicidas & Dinitroanilina & $\mathrm{C}$ \\
\hline
\end{tabular}

GRUPOS CARCINOGÊNICOS: A - carcinogênico aos seres humanos; B - provavelmente carcinogênico aos seres humanos: B1 - indica evidências restritas em seres humanos, B2 - indica evidências suficientes em animais e inadequadas ou não evidentes nos seres humanos; C - possivelmente carcinogênico aos seres humanos; D - não classificado como carcinogênico aos seres humanos; E - não há evidências de efeitos carcinogênicos aos seres humanos. 


\section{REFERÊNCIAS BIBLIOGRÁFICAS}

1. ALBANIS, T.A.; HELA, D.G.; SAKELLARIDES, T.M.; KONSTANTINOU, I.K. Monitoring of pesticides residues and their metabolites in surface and underground waters of Imathia ( $\mathrm{N}$. Greece) by means of solid-phase extraction disks and gas chromatography. Journal of chromatography A, v. 823, p. 59-71. 1998.

2. ALEGRIA, H.A.; DÀUTEL, J.P.; SHAWS, T.J. Offshore transport of pesticides in the South Atlantic Bight: Preliminary estimate of export budgets. Marine Pollution Bulletin. v. 40 n 12, p. 1178-1185, 2000.

3. ALVES FILHO, J.P. Receituário agronômico: a construção de um instrumento de apoio à gestão dos agrotóxicos e sua controvérsia. 2000. Dissertação (Mestrado) Programa de Pós-Graduação em Ciências Ambiental da Universidade de São Paulo - PROCAM. São Paulo.

4. ANA - Agência Nacional de Águas. A Evolução da Gestão dos Recursos Hídricos no Brasil. Março de 2002.

5. ANA - Agência Nacional de Águas. Plano Nacional de Recursos Hídricos - Documento base de referência, cap.3, 4, 7 e 8. Disponível em: <www.ana.gov.br/pnrh/index.htm>. Acesso em 10 ago. 2003.

6. ANVISA. Monografias. Disponível em:

$<$ http://www.anvisa.gov.br/toxicologia/monografias/monografias.pdf $>$. Acesso em 30 jun 2004.

7. ASPERGER, A.; EFER, J.; KOAL, T.; ENGEWALD, W. On the signal response of various pesticides in electrospray and atmospheric pressure chemical ionization depending on the flow-rate of eluente applied in liquid chromatographytandem mass spectrometry. Journal of chromatography $\boldsymbol{A}$, n. 937, p. 6572.2001 . 
8. AZEVEDO, D.A.; LACORTE, S.; VINHAS, T.; VIANA, P.; BARCELÓ, D. Monitoring of pesticides and other organic pollutants in river water from Portugal by gas chromatography-mass spectrometry and liquid chromatography-atmospheric pressure chemical ionization mass spectrometry. Journal of chromatography $A$, v. 879 , p. $13-26.2000$.

9. BAIRD, C. Química Ambiental. 2ª ed. Porto Alegre, RS.: Bookman, 2002.

10. BALINOVA, A. Strategies for chromatoghrahic analysis of pesticides residues in water. Journal of chromatography A, v. 754, p.125-135, 1996.

11. BARCELÓ, D.; VERONIQUE, B.; DURAND, G. Determination of trace levels of herbicide in estuarine waters by gas and liquid chromatographic techniques. Journal of Cromatography, n. 607, p. 319-327, 1992.

12. BARCELÓ, D. Environmental Protection Agency and other methods for the determination of priority pesticides and their transformation products in water. Journal of Cromatography, n. 643, p. 117-143, 1993.

13. BARCELÓ, D. Techniques and instrumentation in analytical chemistry. v. 13: Environmental analysis techniques, applications and quality assurance, 1a. ed., Amsterdam : Elsevier Sciense Plublishers BV, 1993a.

14. BARRIONUEVO, W.R.; LANÇAS, F.M. Extração em fase sólida (SPE) e micro extração em fase sólida (SPME) de piretróides em água. Química Nova, v. 24, n. 2, p. 172-175. 2001.

15. BARTH, F.T. Aspectos institucionais do gerenciamento de recursos hídricos. In: REBOUÇAS, A. C.; BRAGA, B.; TUNDISI, J. G. Águas Doces no Brasil. Editora Escrituras, 1aㅡ edição, 1999, p. 565-598.

16. BEITZ, H.; SCHMIDT, H.; HERZEL, F. Ocurrence, toxicological and ecotoxicological significance of pesticides in groundwater and surface water. In: BÖRNER, H. Pesticides in Ground and Surface Water. Springer-Verlag, Berlim, 1994. 
17. BERNDT, M.P.; HATZELL, H.H.; CRANDALL, C.A.; TURTORA, M.; PITTMAN,J. R.; OAKSFORD, E.T. Water quality in the Georgia-Florida Coastal Plain - Geórgia and Florida, 1992-96. U.S. Department of the Interior, U.S. Geological Survey, circular 1151. 1998.

18. BICKI, T.J, Pesticides and Groundwater - pesticides as potential pollutants. Land \& Water. University of Illinois at Urbana-Champaing. Disponível em: $<$ http://hermes.enc.purdue.edu:8001/cgi/comwgtest?lw-12.il.acü>. Acesso em 28.jul.2004.

19. BIZIUK, M. PRZYJANY, A.; CZERWINSKI, J.; WIERGOWSKI. Occurrence and determination of pesticides in natural and treated waters. Journal of chromatography A, v. 754, p. 103-123. 1996.

20. BOSSI, R.; VEJRUP, K.V.; MOGENSEN, B.B.; ASMN, W.A.H. Analysis of polar pesticides in rainwater in Denmark by liquid chromatography-tandem mass spectrometry. Journal of chromatography A, v. 957, p. 27-36. 2002.

21. BRASIL. GOVERNO FEDERAL. Decreto $n^{\circ}$ 24.643, de 10/07/34. D.O.U., 24/07/34, Rio de Janeiro.1934.

22. BRASIL. MINISTÉRIO DA AGRICULTURA, PECUÁRIA E ABASTECIMENTO. Dados Estatísticos. Disponível em:

<http://agricultura.gov.br>. Acesso em 30 abr. 2004.

23. BRASIL. MINISTÉRIO DO DESENVOLVIMENTO URBANO E MEIO AMBIENTE. CONSELHO NACIONAL DO MEIO AMBIENTE (CONAMA). Resolução do no 20, de 18/06/86, D.O.U., de 30/07/86, Brasília.

24. BRASIL. MINISTÉRIO DO MEIO AMBIENTE. CONSELHO NACIONAL DE RECURSOS HIDRÍCOS. LEI de no 9.433, de 08/01/97. Disponível em:

<http://www.cnrh-srh.gov.br/>. Acesso em 10 ago. 2003. 
25. BRASIL. MINISTÉRIO DO MEIO AMBIENTE. CONSELHO NACIONAL DE RECURSOS HIDRÍCOS. Resolução no 30, de 11/12/02. Disponível em: <http://www.cnrh-srh.gov.br/>. Acesso em 10 ago. 2003.

26. BRASIL. MINISTÉRIO DA SAÚDE. Portaria $n^{0} 1460$ de 29/12/00, Republicada por ter saído com incorreção dos originais no DO no 1- E de 2/1/2001, Seção 1, pág. 19 e no DO nº 7- E de 10/1/2001, Seção 1, pág. 26.

27. BRASIL. MINISTÉRIO DA SAÚDE. Portaria $n^{0} 36$ de 19/01/90, D.O.U., de 23/01/90, Brasília.

28. BRASIL. MINISTÉRIO DA SAÚDE. Portaria $n^{0} 518$ de 25/03/ 2004. Disponível em:

<http://www.funasa.gov.br/sitefunasa/legis/pdfs/portarias_m/pm_518_2004.pdf>. Acesso em 30 mar. 2004.

29. BRUZZONITI, M.C.; SARZANINI, C.; MENTASI, E. Preconcentration of contaminants in water analysis. Journal of Chromatography A, v. 902, p. 289309. 2000.

30. BUSTILLOS, O. V.; SASSINE, A. e MARCH, R. A Espectrometria de massas quadrupolar. Scor Editora Tecci, $1^{\mathrm{a}}$ edição, 2003. p.17-23.

31. CAJATI. Capital nacional da nutrição animal. Disponível em: <http://www.cajati.sp.gov.br>. Acesso em 14 jul. 2004.

32. C.A.T.I. - Coordenadoria de Assistência Técnica Integral. Projeto L.U.P.A. - Levantamento das Unidades de Produção Agropecuária. Disponível em:<http://www.cati.sp.gov.br>. Acesso em 04 jul. 2001.

33. C.A.T.I. - Coordenadoria de Assistência Técnica Integral. Projeto L.U.P.A. - Levantamento das Unidades de Produção Agropecuária. Disponível em:<http://www.cati.sp.gov.br>. Acesso em 04 jul. 2004. 
34. CETEC - Centro Tecnológico da Fundação Paulista de tecnologia e Educação. Relatório de Situação dos Recursos Hídricos da Bacia do Ribeira de Iguape e Litoral Sul, UGRHI-11 - Relatório Zero. Publicação: 20/11/00. Disponível em: <http://www.sigrh.sp.gov.br>. Acesso em: 20 abr. 2004.

35. CETESB - Companhia de Tecnologia de Saneamento Ambiental. Guia de coleta de amostra, 1985.

36. CETESB - Companhia de Tecnologia de Saneamento Ambiental. Relatório de águas interiores do Estado de São Paulo de 2000. Disponível em: <http://www.cetesb.sp.gov.Br/Agua>. "download" - Acesso em: 20 jun. 2002.

37. CETESB - Companhia de Tecnologia de Saneamento Ambiental. Relatório de águas interiores do Estado de São Paulo de 2003. Disponível em: <http://www.cetesb.sp.gov.Br/Agua>. "download" - Acesso em: 17 abr. 2004.

38. CIIAGRO - Centro Integrado e Informações Agrometeorológicas. Disponível em: <http://ciiagro.iac.br>. Acesso em: 12 dez. 2003.

39. CINTRA FILHO, O.A. Análise Crítica da Portaria 1469/MS. Revista Brasileira de Pesquisa e Desenvolvimento. v. 3, p.69-76. 2001.

40. CLUBE de ROMA. Disponível em: <http://www.clubofrome.org>. Acesso em: 12 mar. 2004.

41. COHEN, S.Z.; WAUCHOPE, R.D.; KLEIN, A.W.; EADSFORTH, C.V.; GRANEY, R. Offsite transport of pesticides in water: mathematical models of pesticides leaching and runoff. Pure \& Applied Chemistry. v. 67, n. 12, p. 21092148, 1995.

42. COMPÊNDIO DE DEFENSIVOS AGRÍCOLAS. Guia prático de produtos fitossanitários para uso agrícola. São Paulo, SP. 5ª ed. Editora Andrei, 1996.

43. COTRIM, M.E.B.; FURUSAWA, H.A.; DANTA, S.K.; GELATTI, M.J.G.; BELTRAME FILHO, O.; PINTO, O.E.; BANA, B.; PIRES, M.A.F. Caracterização de 
sedimentos ativos de drenagem em áreas de captação. In: XV ENCONTRO TÉCNICO "SANEAMENTO, DIERITO COM DEVERES” - AESABESP. São Pailo, SP - 30, 31 de ago. e 01 de ste. 2004. Anais do XV Encontro Técnico AESABESP em CD-ROM.

44. COUPE, R. H.; MANNING, M. A.; FOREMAN, W.T.; GOOLSBY, D.A.; MAJEWSKI, M.S. Occurrence of pesticides in rain and air in urban and agricultural areas of Mississippi, April-September 1995. The Science of the Total Environment. v. 248, p. 227-240, 2000.

45. DAEE - Departamento de Águas e Energia Elétrica. Disponibilidade da água na bacia do Ribeira, Relatório 2000.

46. DEAN, J.R.; WADE, G.; BARNADAS, I. Determination of triazine herbicides in environmental samples. Journal of Chromatography A. v. 733, p. 295-335. 1996.

47. DIJKMAN, E.; MOOIBROEK, D.; HOOGERBRUGGE, R.; HOGENDOORN, E.; SANCHO, J.V.; POZO, O.; HERNÁNDEZ, F. Study of matriz effects on the direct trace analisis of acidic pesticides in water using various liquid chromatographic modes coupled to tandem mass spectrometric detection. Journal of Chromatography A. v. 926, p. 113-125. 2001.

48. DOGHEIM, S.M.; MOHAMED, EI-Z.; GAD ALLA, S.A.; EI-SAIED, S.; EMEL, S.Y.; MOCEEN, A.M.; FAHMY, S.M. Monitoring of pesticide residues in human milk, siol, water, and food samples collected from Kafr El-Zayat Governorate. Journal of AOAC International, v. 79, n. 1, p. 111-116. 1996.

49. DONALD, D.B.; SYRGIANNIS, J.; HUNTER, F.; WEISS, G. Agricultural pesticides threaten the ecological integrity of northern prairie wetlands. The Science of the Total Environment, v. 231, p. 173-181. 1999

50. DONALD, D.B; GURPRASAD, N.P.; QUINNETT-ABBOTT, L.; CASH, K. Diffuse geographic distribution of herbicides in northern prairie wetlands. Environmental Toxicology and Chemistry, v. 20, p. 273-279. 2001 
51. DORES, E.F.G.C.; DE-LAMONICA-FREIRE, E.M. Contaminação do ambiente aquático por pesticidas. Estudo de caso: Águas usadas para consumo humano em Primavera do Leste, Mato Grosso - Análise preliminar. Química Nova, v.24, n. 1, p. 27-36. 2001.

52. ECOBICHON, D.J. Pesticide use in developing countries. Toxicology, v. 160, p. 27-22. 2001.

53. EMBRAPA Sistema brasileiro de classificação de solos. Brasília, DF. 1999. p 87-89.

54. EPA - US. Environmental Protection Agency. "Drinking Water Standards and Health Advisories". D.C.EPA - 822-B-00-001, 2000.

55. EPA - US. Environmental Protection Agency. Results of the lake Michigan mass balance study: Atrazine Date Report. EPA 905R-01-010. 2001.

56. EPA - US. Environmental Protection Agency. "Water quality guidance for the great lakes system". Disponível em:

<http://www.epa.gov/owow/tmdl/glsprohibit.pdf>. Acesso em 19 ago. 2003.

57. EPA - US. Environmental Protection Agency. National Primary Drinking Water Standards. Disponível em:

<http://www.epa.gov.safewater/standards.html>. Acesso em: 11 maio 2004.

58. EPA - US. Environmental Protection Agency. National Environmental Methods Index. Disponível em:

<http://www.nemi.gov.html>. Acesso em: 30 set. 2004.

59. ESTEVES, F.A. Fundamentos de Limnologia. Ed. Interciência, FINEP, Rio de Janeiro. 1988.

60. FAO - Food Agriculture Organization. Control of Water Pollution from agriculture. GEMS/Water Collaborating Centre, Canada Centre for Inland Waters, Burlington, 1996, Paper n. 55. 
61. FAO - Food Agriculture Organization. FAOSTAT. Disponível em : <http://faostst.fao.org/default.jsp?language=EN>. Acesso em: 15 abr. 2004.

62. FOREMAN, W.T.; MAJEWSKI, M.S.; GOOLSBY, D.A.; WIEBE, F. W.; COUPE, R. H. Pesticides in the atmosphere of the Mississippi River Valley, part IIair. The Science of the Total Environment. v. 248, p. 213-216, 2000.

63. FRICK, E.A.; HIPPE, D.J.; BUELL, G.R.; COUCH, C.A.; HOPKINS, E.H.; WANGSNESS, D.J.; GARRETT, J.W. Water quality in the Apaachicola Chattahoochee - Flint River Basin - Georgia, Alabama,and Florida1992-95. U.S. Department of the Interior, U.S. Geológical Survey, circular 1164. 1998.

64. GASCÓN, J.; OUBIÑA, A.; FERRER, I.; ÖNNERFJORD, P.; MARKOVARGA, G.; HAMMOCK, B.D.; MARCO, M.P.; BARCELÓ, D. Performance of two immunoassys for the determination of atrazine in sea water samples as compared with on-line solid phase extraction-liquid chromatography-diode array detection. Analytica Chimica Acta, v. 330, p. 41-51. 1996.

65. GOODWIN, L.; STARTIN, J.R.; GOODALL, D.M.; KEELY, B.J. tandem mass spectrometric analysis of glyphosate, glufosinate, aminomethylphosphonic acid and methylphosphinicopropionic acid. Rapid Communications in Mass Spectrometry, v. 17, p. 963-969. 2003.

66. GOSS, D. W. Screening procedure for soils and pesticides for potencial water quality impacts. Weed Technology. v.6, p. 701-708. 1992.

67. GUERRA, M. S. \& SAMPAIO, D. P. A. Receituário Agronômico. São Paulo: Editora Globo. p. 436. 1991.

68. HASSUDA, S. Água subterrânea: um recurso a proteger. In: CHASSOT, A.; CAMPOS, H. Ciências da terra e meio ambiente: Diálogos para (inter)ações no Planeta. São Leopoldo, RS, 2000. Ed. Unisinos. P. 179-196.

69. HAYES, W. J.; LAWS, E. R. Handbook of Pesticides Toxicology. 1a. ed. Academic Press, San Diego, 1997. 
70. HERNÁNDEZ, F.; SANCHO, J.V.; POZO, O.; LARA,.A.; PITARCH, E. Rapid direct determination of pesticides and metabolites in environmental water samples at sub- $\mu \mathrm{g} / \mathrm{l}$ level by on-line solid-phase extration-liquid chromatographyelectrospray tandem mass spectrometry. Jounal Chromatography A, v. 939, p. 111. 2001.

71. HOGAN, D. J.; CARMO, R. L.; ALVES, H. P. F.; RODRIGUES, I. A. Desenvolvimento sustentável no Vale do Ribeira (SP): conservação ambiental e melhoria das condições de vida população. Disponível em:

<www.unicamp.br/nepo/staff/roberto/valeribeira.htm>. Acesso em: 10 dez. 2001.

72. HOSTETLER, K. A.; THURMAN, E.M. Determination of chloroacetailide herbicide metabolites in water using high-performace liquid chromatography-diode array detection and high-performance liquid chromatography/mass spectrometry. The Science of the Total Environment, v. 248, p. 147-155. 2000.

73. IBAMA - Instituto Brasileiro do Meio Ambiente e dos Recursos Naturais Renováveis. Gestão dos Recursos Naturais: subsídios à elaboração da agenda 21 brasileira: MMA; IBAMA. 2000.

74. IBGE - Instituto Brasileiro de Geografia e Estatística. Censo Agropecuário 1995/1996. no 19, São Paulo. 1997.

75. IBGE - Instituto Brasileiro de Geografia e Estatística. Pesquisa Nacional de Saneamento Básico. 2002, Rio de Janeiro.

76. INFOVALE. Município de Sete Barras. Disponível em: <http://infovale.com/setebarras>. Acesso em 14 jul. 2004.

77. INPE - Instituto Nacional de Pesquisas Espaciais. Ministério da Ciência e Tecnologia. Disponível em: <http://www.inpe.br>. Acesso em 20 ago. 2004.

78. IPT - Instituto de Pesquisas Tecnológicas. Mapa geomorfológico do Estado de São Paulo. 1'a . ed., v. 2, 1997. 
79. JAVARONI, R.C.A.; LANDGRAF, M.D.; REZENDE, M.O.O. comportamento dos herbicidas atrazina e alaclor aplicados em solo preparado para o cultivo de cana-de-açúcar. Química Nova. v. 22, p. 58-64. 1999.

80. JUQUITIDA. Câmara Municipal - São Paulo. Disponível em: <http://www.camarajuquitiba.sp.gov.br/historico.php>. Acesso em: 14 jul.2004.

81. KATSUÓKA, L.; PIRES, M. A. F.; VAZ, J. M.; COTRIM, M. E. B. Monitoramento de compostos orgânicos em águas e sedimentos em municípios pertencentes à Unidade Gerencial de Recursos Hídricos 9 - Alto Mogi-Guaçu. IN: VI ENCONTRO DE ECOTOXICOLOGIA. 3-6 de setembro de 2000. Livro de Resumos. p. 68-69.

82. KATSUÓKA, L. Avaliação do Impacto da Atividade Agropecuária na Qualidade da Água em Áreas de Captação Superficial nas Bacias Hidrográficas dos Rios Mogi-Guaçu e Pardo, São Paulo. 2001. Tese (Doutorado) - Instituto de Pesquisas Energéticas e Nucleares, São Paulo.

83. KOH, D.; JEYARATNAM, J. Pesticides hazards in developing countries. The Science of the Total Environment, v.188, s.1, p. S78-S85. 1996.

84. KOLPIN, D.W.; THURMAN, E.M.; LINHART,S.M. Finding minimal herbicide concentrations in ground water? Try looking for their degradates. The Science of the Environment, v. 248, p. 115-122. 2000.

85. KOMATSU, E. Desenvolvimento de metodologia para determinação de alguns pesticidas em águas empregando microextração em fase sólida (SPME). 2004. Dissertação (Mestrado) - Instituto de Pesquisas Energéticas e Nucleares, São Paulo.

86. KOOKANA, R.S.; BASKARAN, S.; NAIDU, R. Pesticide fate and behavior in Australian soils in relation to contamination management of soil and water: a review. Australian Journal Soil Res. v. 36, p. 715-764. 1998. 
87. LARINI, L. Toxicologia dos Praguicidas. São Paulo,SP. Editora Manole, 1999.

88. LEBRE, D.T. Desenvolvimento de metodologia para a determinação de herbicidas e inseticidas em águas superficiais utilizando extração líquido sólido e cromatografia líquida de alta eficiência. 2000. Dissertação (Mestrado) - Instituto de Pesquisas Energéticas e Nucleares, São Paulo.

89. LEBRE, D.T.; MARTINS Jr, H.A.; WANG, A.; BUSTILOS, O.V.; PIRES, M.A.F. Direct and sensitive analises of pesticides in juices by electrospray - ESI Tandem mass spectrometry (LC-MS/MS). In: $X$ CONGRESSO LATINO AMERICANO DE CROMATOGRAFIA E TÉCNICAS AFINS - COLACRO. 20-22 de outubro de 2004.Campos de Jordão, SP. Livro de Resumos p. 109.

90. LEHOTAY, S.J.; HARMAN-FETCHO, J.A.; MCCONNELL, L.L. Agricultural pesticide residues in oysters and water from two Chesapeake Bay tributaries. Marine Pollution Bulletin. v. 37, n 1-2, pp. 32-44. 1998

91. MAJEWSKI, M.S.; FOREMAN, W.T.; GOOLSBY, D.A. Pesticides in the atmosphere of the Mississippi River Valley, part I-rain. The Science of the Total Environment. v. 248, p. 201-212, 2000.

92. MATHESS, G. Fate of Pesticides in Aquatic Environments. In: BÖRNER, H. (Editor) Pesticides in Ground and Surface Water. Chemistry of Plant Protection. Spring Verlag, Berlin, 1994, p. 191-246.

93. MARQUES, M.N.; COTRIN, M.E.B.; PIRES, M.A.F. Pesticide Monitoring in Ribeira Valley, Southeastern Brazilian. In: XI World Water Congress - Water Resources Management in the $21^{\text {st }}$ Century, 2003, Madrid. Anais do XI World Water Congress, 2003. 1 CD-ROM. 
94. MARQUES, M.N.; COTRIM, M.E.B.; BELTRAME FILHO, O.; LEBRE, D.T.; PINTO, O.E.; HIROI, J.; PIRES, M.A.F. Avaliação de carbofuran e carbaril em água bruta e tratada na Bacia Hidrográfica do Ribeira de Iguape. In: XV ENCONTRO TÉCNICO "SANEAMENTO, DIERITO COM DEVERES" AESABESP. SÃO PAILO, SP - 30, 31 de ago. e 01 de set. 2004. Anais do $X V$ Encontro Técnico AESABESP em CD-ROM.

95. MOLANDER, S., MORAES, R. Ecological Risk Assessment of human impact on Ecosystems in Parque Estadual Turístico do Alto Ribeira (PETAR), State of São Paulo, Brazil. Status Report from an ERA Project. August 1998. Technical Environmental Planning CTH. Report 1998. p. 3-43.

96. NEAL, C.; HOUSE, W. A.; WHITTON, B. A.; LEEKS, G.J.L. Foreword to special issue: Water quality and biology of UK rivers entering the North Sea: The Land Ocean Interaction Study (LOIS) and assiciated work. The Science of the Total Environment. N. 210-211, p. 1-4, 1998.

97. NEAL, C.; WILLIAMS, R. J.; NEAL, M.; BHARDWAJ, L. C.; WICKAM, H.; HARROW, M.; HILL, L. K. The water quality of the River Thames at a rural site downstream of Oxford. The Science of the Total Environment. n. 251-252, p. 441-457, 2000a.

98. NEAL, C.; JARVIE, H. P.; WHITTON, B. A.; GEMMELL, J. The water quality of the river wear, north-east England. The Science of the Total Environment. $\mathrm{n}$. 251-252, p. 153-172, 2000b.

99. NEUHAUS, B.K.; HURLBUT, J.A.; HAMMACK, W. LS/MS/MS analysis of chloramphenicol in shrimp. U.S. Food and Drug Administration - Laboratory Information Bulletin, v. 18, n. 9, September 2002.

100. OHLENBUSCH, G.; ZWIENER, C.; MECKENSTOCK, R.U.; FRIMMEL, F.H. Indentification and quantification of polar naphthalene derivatives in contaminated groundwater of a former gas plant site by liquid chromatography-electrospray 
ionization tandem mass spectrometry. Journal of Chromatography A, v. 967, p. 201-207. 2002.

101. OMS - Organización Mundial de la Salud. Guias para la calidad del agua potable. Segunda edicion, vol 1. Recomendaciones, 1995.

102. OMS - Organización Mundial de la Salud. Disponível em <http://www.who.int/water_sanitation_health/en/factsfigures04.pdf>. Acesso em 09 jun. 2004.

103. OUBIÑA, A., MARTINEZ; E. GASCÓN, J.; BARCELÓ, D.; ALLELUIA, I.B. Monitoring of insecticides and fungicides in water and sediment samples in the Brazilian environment. International Journal Environmental Analitical Chemistry. v. 70, p. 75-91. 1998.

104. PAULINO, W.R. Biologia Atual. Editora Ática S.A., SP, 1991 p 50-75.

105. PEREIRA, W.E.; ROSTAD, C.E.; LEIKER, T.J. Determination of trace levels of herbicides and their degradation products in surface and ground waters by gas chromatography/ion-trap mass spectrometry. Analytica Chimica Acta, v. 228, p. 69-75. 1990.

106. PIRES, M.A.F.; COTRIM, M.E.B; MARQUES, M.N.;BOHERE-MOREL, M.B.C.; MARTINS, E.A.J. Qualidade da água para consumo humano: uma oportunidade de avaliação da concepção e aplicabilidade da nova legislação Portaria 1469/MS/00. Revista Brasileira de Pesquisa e Desenvolvimento. v. 3, p. 127-138. 2001.

107. PIRES, M.A.F.; MARQUES, M.N.; COTRIM, M.E.B. Avaliação de novos herbicidas no controle de qualidade da água dos mananciais. In. II CONGRESSO BRASILEIRO DE PESQUISAS AMBIENTAIS E SAÚDE, 03-04 de junho,2002, Santos - SP. Anais do II Congresso Brasileiro de Pesquisas e Saúde. Em CDROM. 
108. PIRES, M. A. F Análise crítica da legislação sobre potabilidade das águas destinadas ao abastecimento público. Relatório técnico final FAPESP PP Projeto $n^{\circ}$ 00.02024-4. 30/06/2004.

109. PNGSQ. Perfil Nacional da Gestão de Substancias químicas. Relatório, Brasília, 2003. Disponível em: <http://www.mma.gov.br/>. Acesso em $10 \mathrm{dez}$. 2003.

110. POMPEU, C. T. Regime jurídico da polícia das águas públicas; polícia da qualidade. São Paulo: CETESB, 1976.

111. PROJETO ÁGUA. Disponível em:

<http://www.eco.unicamp.br/nea/agua/artigos.html>. Acesso em 10 ago. 2003.

112. QUINTANA, J.; MARTI, I.; VENTURA, F. Monitoring of pesticides in drinking and related in NE Spain with a multiresidue SPE-GC-MS method including an estimation of the uncertainty of analytical results. Jounal of chromatographry A. v. 938 , p. 3-13. 2000.

113. RAO, P.S.C.; HORNSBY, A.G. Behavior of Pesticides in soils and water. University of Florida-Cooperative Extension Service - Institute of food and agricultural sciences. Disponível em:

<http://edis.ifas.ufl.edu/BODY_SS111>. Acesso em: 26 set 2003.

114. REBOUÇAS, A. C. Águas Subterrâneas. In: REBOUÇAS, A. C.; BRAGA, B.; TUNDISI, J. G. Águas Doces no Brasil. Editora Escrituras, 1"a edição, 1999.

115. RENÉ van der HOFF, G.; van ZOONEN, P. Trace análisis of pesticides by gas chromatography. Jounal of chromatographry A. v. 843, p. 301-322. 1999.

116. ROBB, D.B.; COVEY, T.R.; BRUINS, A.P. Atmospheric pressure photoinization: An ionization method for liquid chromatography-mass spectrometry. Analytical Chemistry. v. 72, p. 3653-3659. 2000. 
117. RODRIGUES, B. N.; ALMEIDA, F. S. Guia de herbicidas, Londrina, PR. 4⿻ edição, 1998.

118. SABIK, H.; JEANNOT, R.; RONDEAU, B. Multiresidue methods using solidphase extraction for monitoring priority pesticides, including triazines and degradation products, in ground and surface waters. Journal of chromatography A, v. 885 , p. $217-236.2000$.

119. SABESP - Companhia de Saneamento Básico do Estado de São Paulo. Dispinível em:<htpp://www.sabesp.com.br>. Acesso em 04 abr. 2004.

120. SANCHO, J.V.; HERNÁNDEZ, F.; LÓPEZ, F.J.; HOGENDOORN, E.A.; DIJKMAN, E. Rapid determination of glufosinate, glyphosate and aminomethylphosphonic acid in environmental water samples using precolumn fluorogenic labeling and coupled-column liquid chromatography. Journal of Chromatography A, v. 737, p. 75-83. 1996.

121. SÃO PAULO. Lei Estadual $n^{\circ}$ 997/79/SP, regulamentada pelo Decreto $n^{\circ}$ 8.468/76/SP. Dispõe sobre o controle da poluição do meio ambiente.

122. SÃO PAULO. Lei Estadual $n^{0} 7.663 / 91 / S P$. Institui a política estadual de recursos hídricos.

123. SÃO PAULO. Resolução SS $n^{\circ}$ 178/96/SP da Vigilância Sanitária do Estado.

124. SÃO PAULO. Secretaria do Meio Ambiente (SMA) / Secretaria da Educação. Programa de Educação Ambiental do Vale do Ribeira. 1992

125. SÃO PAULO. Secretaria de Estado da Agricultura e Abastecimento (SEAA). Disponível em:

<http://www.agroportal.sp.gov.br>. Acesso em : 28 set. 2004. 
126. SCHENCK, F.J.; LEHOTAY, S.J. Does futher clean-up reduce the matrix enhancement effect in gas chromatographic analysis of pesticide residues in food? Jounal of Chromatography A, n. 868, p. 51-61. 2000.

127. SEDAE - Fundação Sistema Estadual e Analise de Dados. Disponível em:<http:// www.sedae.gov.br>. Acesso em : 10 set. 2002.

128. SETTI, A. A.; LIMA, J. E. F. W.; ChAVES, A. G. M.; PEREIRA, I.C. Introdução ao gerenciamento de recursos hídricos. Agencia Nacional de Energia Elétrica, Superintendência de estudo e informações hidrológicas. 2000, p. 207, ed. Multimídia, Brasília, 2001.

129. SHERMA, J. Pesticides. Analytical Chemistry, v. 67, n. 12, p. 1R20R.1995.

130. SIGRH - Sistema Integrado de Gerenciamento dos Recursos Hídricos do Estado de São Paulo. Relatório de Situação dos Recursos Hídricos do Estado de São Paulo, Junho, 2000. Disponível em: <http://www.sigrh.sp.gov.br>. Acesso em 10 abr. 2002.

131. SILVA, E.R. O curso da água na história: simbologia, moralidade e a gestão de recursos hídricos. 1998. Tese (Doutorado) - FUNDAÇÃO OSWALDO CRUZ -ESCOLA NACIONAL DE SAÚDE PÚBLICA - PÓS-GRADUAÇÃO EM SAÚDE PÚBLICA.

132. SINDAG - Sindicato Nacional da Indústria de Produtos para Defesa Agrícola. Disponível em: <http://www.sindag.com.br> Acesso em 08 ago. 2002 25 jul. 2004.

133. STACHEL, B.; ELSHOLZ, O.; REINCKE, H. Investigations on sample pretreatment for the determination of selected metals and organochlorine compounds in suspended particulate matter of the River Elbe. Fresenius `Journal of Analytical Chemistry. v. 353, p. 21-27. 1995. 
134. STACKELBERG, P.E. et al. Frequently co-occurring pesticides and volatile organic compounds in public supply and monitoring wells, southern new Jersey, USA. Environmental Toxicology and Chemistry, v. 20, nº 4, p. 853-865. 2001

135. STALIKAS, C.D.; KONIDARI, C.N. Analytical methods to determine phosphonic and amino acid group-containing pesticides. Journal of Chromatography A, v. 907, p. 1-19. 2001.

136. STANDARD METHODS FOR THE EXAMINATION OF WATER AND WASTE WATER.-19 ${ }^{\text {th }}$ Edition New York, NY; 1997. Carbamate pesticide (6610)/HPLC Method. P. 6-109 a 6-114.

137. TADEO, J.L.; SÁNCHEZ-BRUNETE, C.; PÉREZ, R.A.; FERNÁNDEZ, M.D. Analysis of herbicide residues in cereals, fruits and vegetables. Journal of Chromatography A, v. 882, p. 175-191. 2000.

138. TATTON, J.E. Água na história até o ano zero da era cristã. Associação Guardiã da Água, São Paulo, SP. Disponível em:

<http://www.agua.bio.br/botao_e_I.htm>. Acesso em 20 jan.2004.

139. TAYLOR, J.K. Validation of analytical methods. Analytical Chemistry. v. 55, p. 600A. 1983.

140. TELLES, D. D. Água na agricultura e pecuária. In: REBOUÇAS, A. C.; BRAGA, B.; TUNDISI, J. G. Águas Doces no Brasil. Editora Escrituras, 1a edição, 1999, p.305-337.

141. THOMAS, K.V.; THAIN, J.E.; WALDOCK, M.J. Identification of toxic substances in United Kingdom estuaries. Environmental Chemistry, v. 18, n. 3, p. 401-411. 1999.

142. TOMILIN, C The pesticide manual - incorporating the agrochemicals handbooks. United Kingdom: Crop Protection Publications, 1994. 
143. TOXNET National library of medicine. Disponivel em:

<http:// toxnet.nIm.nih.gov>. Acesso em 20 maio 2004.

144. URENIUK, G. Os recursos hídricos da Bacia do Rio Ribeira de Iguape e do Litoral Sul. In: SECRETARIA DE ESTADO DO MEIO AMBIENTE/ Secretaria da Educação.1989. Programa de Educação Ambiental do Vale do Ribeira:cap. 4. p. $121-151$.

145. van der WERF, H.M.G. Assessing the impact of pesticides on the environment. Agriculture, Ecosystems and Environment, v. 60, p. 81-96. 1996.

146. YING, G.-G.; WILLIAMS, B. Laboratory study on the interaction between herbicides and sediments in water systems. Environmental Pollution, v. 107, p. 399-405. 2000.

147. ZUIN, V.G. Determinação de Pentaclorofenol e Hexaclorobenzeno em Águas Naturais de superfícies de Áreas Afetadas por Resíduos de Organoclorados. 1997. Dissertação (Mestrado). Universidade de São Paulo, São Carlos -SP. 